
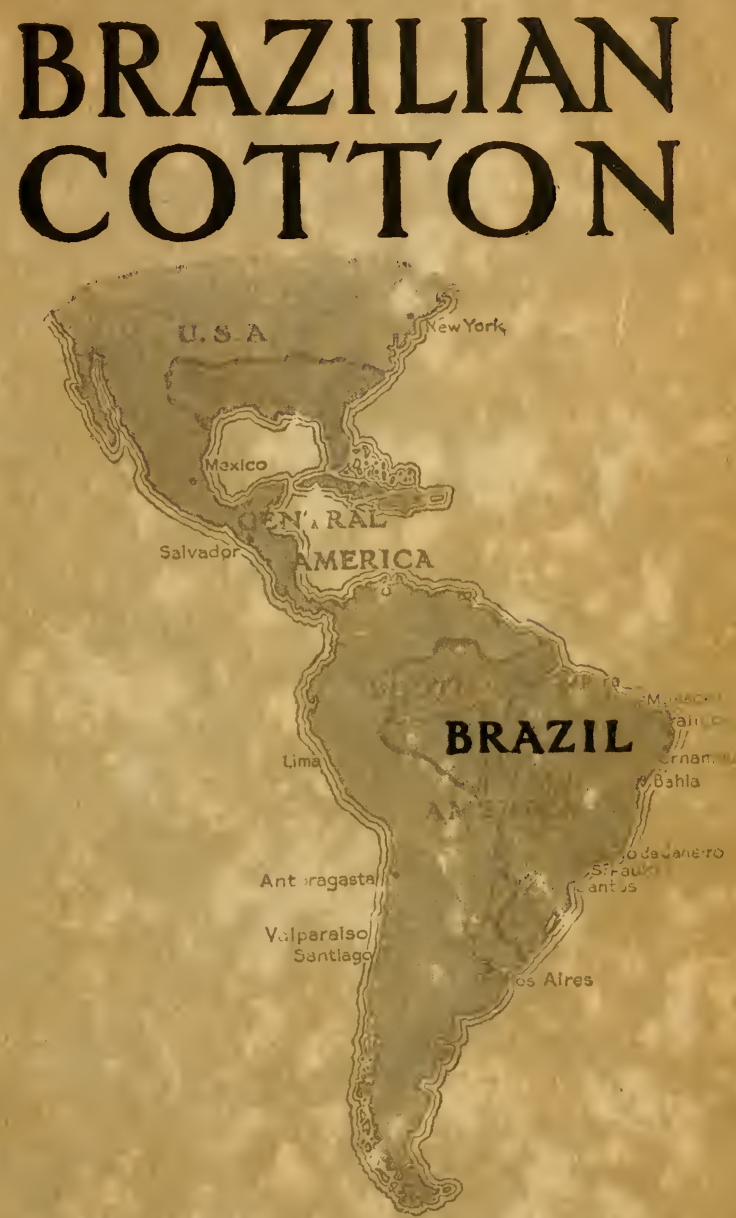

INTERNATIONAL FEDERATION OF MASTER COTTON SPINNERS \& MANUFACTURERS' ASSOCIATIONS MANCHESTER ENGLAND. 


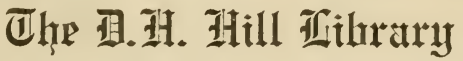

Durtḩ Carnlina State Callege

$$
\begin{aligned}
& \text { SB2 } 51 \\
& \text { B8P42 }
\end{aligned}
$$

\section{LIBRARY}

OF THE

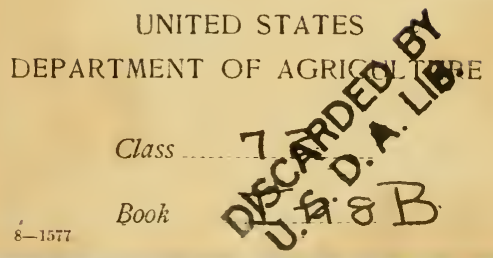


THIS BOOK IS DUE ON THE DATE INDICATED BELOW AND IS SUBJECT TO AN OVERDUE FINE AS POSTED AT THE CIRCULATION DESK.

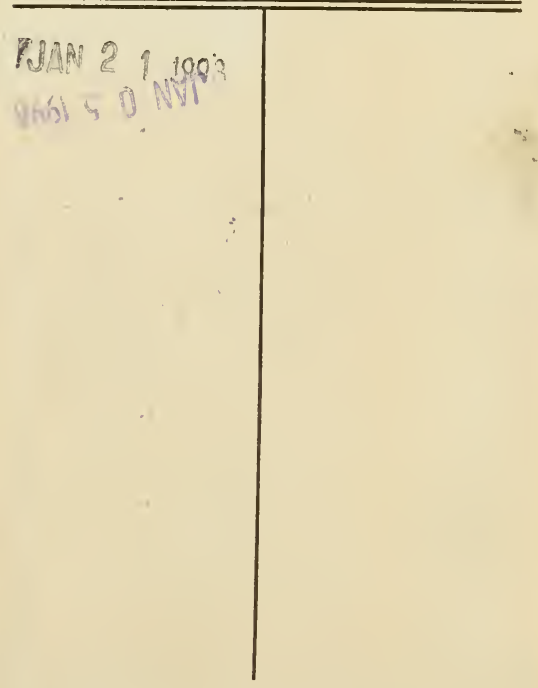




\section{BRAZILIAN COTTON}


Printed by

Taylor Garnett Evans \& Co.

(Huitson is Kiearts, Ltd.)

Manchester

England 



$$
\therefore
$$

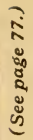

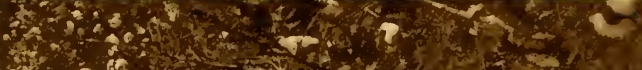
xat os

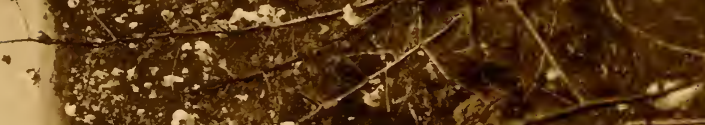

$$
\begin{aligned}
& \text { s. }
\end{aligned}
$$

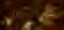

$$
\begin{aligned}
& \text { di. } \\
& x-2
\end{aligned}
$$

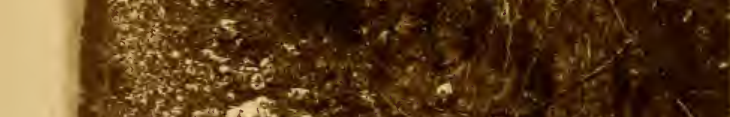

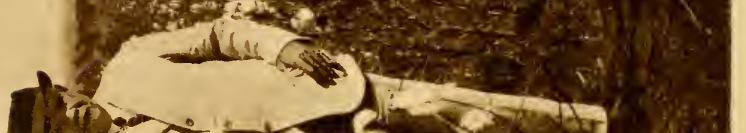

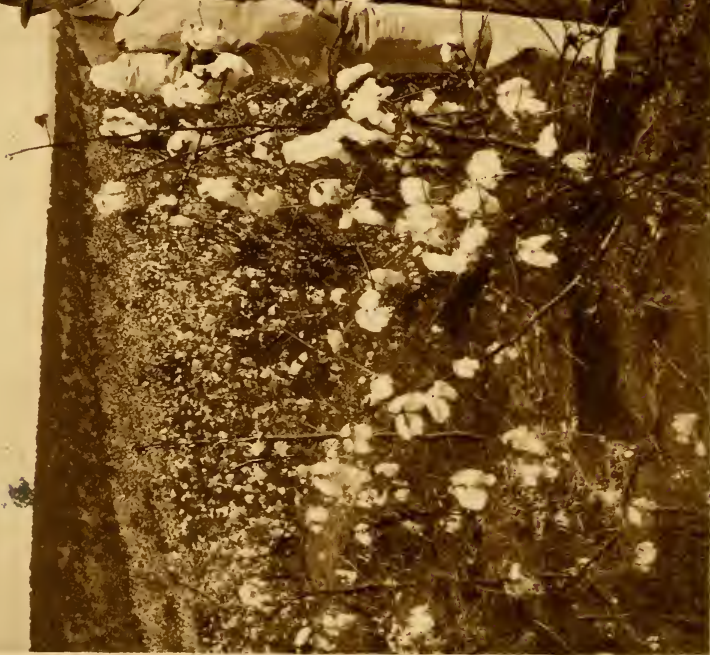

을

-

น 胥 $\infty$

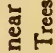
플 密 


\section{BRAZILIAN COTTON}

\section{Being the}

Report of the Journey of the International Cotton Mission through the Cotton States of SÃO PAULO, MINAS GERAES, BAHIA, ALAGÔAS, SERGIPE, PERNAMBUCO, PARAHYBA, RIO GRANDE DO NORTE

\section{By \\ ARNO S. PEARSE,}

General Secretary of the International Federation of Master Cotton Spinners' and Manufacturers' Associations, Manchester

$$
\begin{aligned}
& \text { OISCARSISCAREEO IV } \\
& \text { U.S T.RO SW. A. LU. }
\end{aligned}
$$

MARCH to SEPT EldBER, I92 
ALL RIGHTS RESERVED

$$
\begin{aligned}
& \text { ؛ } \\
& \text { 茲 }
\end{aligned}
$$




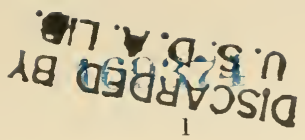

\title{
INTERNATIONAL COMMITTEE
}

\author{
JOHN SYZ (Switzerland), President. \\ JOHN SMETHURST (England), Vice-President. \\ Comte JEAN de HEMPTINNE (Belgium), ไ Hon. Treasurers. \\ GEORGIO MYLIUS (Italy), \\ ARNOST ZUCKER (Czecho-Slovakia). \\ F. A. HARGREAVES (England). \\ F. HOLROYD (England). \\ HENRI MANUEL (France). \\ JOAN GELDERMAN (Holland). \\ Sir THOMAS SMITH, M.L.C. (India). \\ KONOSUKE SEKO (Japan). \\ SAN'TIAGO TRIAS (Spain). \\ A. H. HÅKANSON (Sweden). \\ Norway, Portugal and Denmark are represented by the President. \\ The delegates for Brazil and China have not yet been appointed.
}

General Secretary :

ARNO S. PEARSE.

\section{Assistant Secretary : JOHN POGSON.}

Auditors :

DAVID SMITH, GARNETT \& CO.,

Chartered Accountants.

Bankers :

THE LANCASHIRE \& YORKSHIRE BANK, LTD., Spring Gardens, Manchester.

$$
\begin{aligned}
& \text { Solicitors : } \\
& \text { JOHN TAYLOR \& CO., } \\
& \text { 12, Exchange St., Manchester. }
\end{aligned}
$$

Head Offices: 5Th Floor, 525, Royal Exchange, Manchester. Telegraphic Address : "Invite," Manchester.

Telephone: 1520 Ciтr. 



\section{CONTENTS}

INTERNATIONAL COMMITTEE

. $\quad$. $\quad \ldots \quad \ldots$

BRAZILIAN MONEY, WEIGHTS AND MEASURES .. 8

$\begin{array}{llllllllll}\text { INTRODUCTION } & \ldots & \ldots & \ldots & \ldots & \ldots & \ldots & \ldots & 9\end{array}$

Invitation-Composition of International Cotton Mission-President of United States of Brazil's Attitude towards Cotton-Assistance rendered by Government-Books of Reference-Itinerary-Method of Collecting and Imparting Information-Resolutions of International Committee on Report-International Cotton Congresses at Stockholm and Rio de Janeiro in 1922.

\section{CHAPTER I}

\section{GEOGRAPHY}

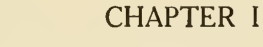

Boundaries, etc.-Density of Population-Immigration-Grants by Government-Nationalities of Immigrants-Climate-Death RateClimatic Zones-Rainfall-Waterways-Railways.

HISTORY OF BRAZIL .. $\quad \ldots \quad \ldots \ldots \ldots$

Constitution and Government-Taxes of Federal and State Governments-Export Tax-Characteristics of Brazilians.

\section{CHAPTER $\mathrm{II}_{A}$}

\section{COTTON SPINNING AND WEAVING INDUSTRY ..}

Early Development-Hand Spinning and Weaving-Table of Cotton Mills, with Capital, Spindles, Looms, ete.-Falling-off of ImportsCotton Mill Machinery-Spinning-Weaving-Cotton Used-WagesPedra Mill-Paulo Affonso Falls-Electricity-Fuel-Profits-Trado Organisations-Welfare Work-Tables of Imports of Cotton Piece Goods and Yarns-Table of Exports of Cotton Piece Goods.

\section{CHAPTER III}

\section{GENERAL REMARKS ON BRAZILIAN COTTON ..}

Indigenous Cotton-Early Development-Cotton Important again to Assist in Poli-cultivation-Remarkable cotton yields destine Brazil to occupy prominent place as World's supplier.-World's Shortage of Staple Cotton-Egypt's Decreasing Yields-North-east Brazil and São Paulo's future lie in Cotton-General prospects of Alagôas, Sergipe, Bahia, Minas,-Drawbacks: Shortage of Population-GinningDifference in Cotton Ginned by Roller and Saw-gins-Mixing of Seed -Cotton Seed Farms-Establishment of Ginning Factories-Production of Roller-gins as compared with Saw-gins-Necessity of recognising Quality and Grade-Insect Pests-Exports of Raw Cotton and Countries of Destination-Annual Mill Consumption-Annual Production.

\section{CHAPTER IV}

\section{STATE OF SÃO PAULO}

$$
\text { a } \quad \text { Import }
$$

Geographical Notes-Exports and Imports-São Paulo's Powerful Position in United States of Brazil-National Pride- "Bandeirantes." 
SÃO PAULO COTTON

Kind of Cotton-Cotton Zones-Sorocaba-Method of CultivationCampo Largo - Snake Farm at Butantan - Indian Corn Mill Aterradinho-Itapeteninga-Capão Alto-Rossinha-Manoel Guedes -Tatuhy-Villa Americana-Fazenda Salto Grande-Santa Gertrudes -Instituto Agronomico, Campinas-Piracicaba-Biriguy-Hydraulic Bale Press.

$\begin{array}{llllllll}\text { COFEEF } & \ldots & \ldots & \ldots & \ldots & \ldots & \ldots & \ldots\end{array}$

World's Production-World's Consumption-Exports-Description of Plantation-Terms of Contract for Colonists-Method of Preparation of Beans.

\section{CHAPTER V}

STATE OF MINAS GERAES .. $\quad \ldots \quad \ldots \quad \ldots \quad \ldots$

Geographical Notes-Seven Cotton Zones-Description of Varieties Grown-Cotton Grown in Small Lots-Extension Dependent on Future Improvement of Transportation-Ginning Methods.

SÃO FRANCISCO RIVER _

Geographical Notes-Pirapora-São Francisco-Januario-JacarayMango de Japoray.

\section{CHAPTER VI}

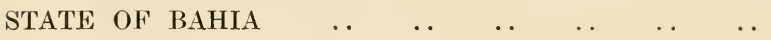

Geographical Notes-Cotton Zones.

SÃO FRANCISCO (Contd.) _. $\quad$.

Carinhanha-Barrero Grande-Rio Branco-Macaubas-Bom Jardin - Torrinha-Barra do Rio Grande-Chique Chique-Pilao ArcadoRemanso-"Verdão Cotton"-Casa Nova-Joazeiro-"Horto Florestal "-Bomfim - Queimadas - Santa Luzia - Serrinha — "Centro Industrial do Algodão"-Bahia-Alagoinhas.

\section{CHAPTER VII}

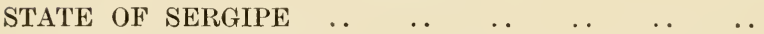

Geographical Notes-Entrepôt Warehouse-Cotton Zones-Byquim-São Christovão-Maroim-Japaratuba-Propria-Aquidaoan.

\section{CHAPTER VIII}

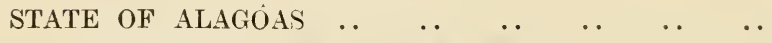

Geographical Notes-Pão D'Assucar-Pedra-Inhapi-Lagôa do Algodão-Sant' Anna do Ipanema.

\section{CHAPTER IX}

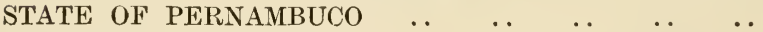

Geographical Notes-Cotton Zones-São José do Egypto-CorrentesFlores-Timbauba-Bom Jardim-Caruarú-Garanhums-Gloria do Goyta - Limeoeiro - Nazareth - Afogados - Brejo - TaquauatingaCaetano-Sapé-Alagôa do Baixo-Barrão do Rio Braneo-Motor Roads. 


\section{CHAPTER X}

STATES OF PARAHYBA AND RIO GRANDE DO NORTE

Geographical Notes-Four Cotton Zones-Commercial Cotton Classification-Droughts-Difficulties of Travel-Method of CultivationMocó Cotton-Lages-Baixa Verde-Fazenda Joazeiro-Angicos Assú - Jaguaribe Valley - Aracaty - Carahubas - Fraudulent Packing Fazenda Fortuna-Uruguayana-Colonia-São Antonio--São Fernando.

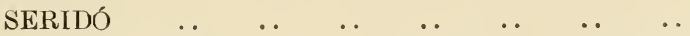

Geographical Notes-Cotton Production-Dams-Taboleira LandScarcity of Labour-Gins-Valle do Saboeiro-Fazenda São NicolauValle de S. José-Cruzêta-Epinal-Barragem Gargalheira-Jardim do Seridó-Fazenda Volta do Espirito Santo-Sombrio-ParelhasFazenda Velha-Valle de São Bentos.

Santa Luzia-São Mamede-Pombal-Campina Grande-MaranhãoPiauhy-Ceará.

SOME PHYSICAL QUALITIES OF MOÇÓ COTTONSi

By Dr. W. Lawrence Balls

Scientific Tests of Hair Break-Wall Thickness-Ribbon WidthHair Weight-Length Measurements-General Comments-Chart of Hair Lengths.

\section{CHAPTER XI}

\section{COTTON EXPORT HOUSES OF PERNAMBUCO, PARA-} HYBA AND RIO GRANDE DO NORTE .. .

Baling-Sampling-Density-Grading-List of Exporters and Shipping Marks-Motor Roads-Revolutionizing System of Trading-Campinas Merchants-Campanhia Industrial de Algodão e Oleos-Sociedade Algodoeira do Nordeste Brazileiro.

\section{CHAPTER XII}

THE PRINCIPAL EXPORT PRODUCTS OF BRAZIL . .

Sugar-Cattle-Frozen Meat-Hides-Cocoa-Rubber-Herva MatéTobacen-Mining-Cereals-Mandioca-Carnauba.

BRAZILIAN INDUSTRIES _. $\quad \ldots \quad \ldots$

RATES OF EXCHANGE-1919, 1920 AND 1921 _. 194

APPENDIX . .

List of Brazilian Cotton Mils with full particulars as to number of Spindles, Looms, Kinds of Goods Produced, Capital, etc.

Adpress by Arno S. Pearse at Rio de Janeiro before the "Sociedade Nacional de Agricultura," under the Chairmanship of His Excellency Illmo. Ildefonso Simões Lopes, Minister of Agrieulture. 


\section{LIST OF ILLUSTRATIONS}

São Paulo Cotton Field near Tatuhy ... . Frontispiece Inset Views of Rio de Janeiro .. . . . . Facing 20

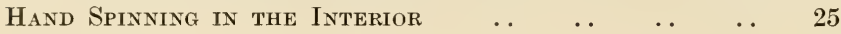
$\begin{array}{llllllll}\| & \ldots & \ldots & \ldots & \ldots & \ldots & 26\end{array}$

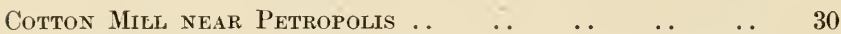

Part View of Paulo Affonso Falls . $\quad \ldots \quad \ldots \quad \ldots \quad$. $35-36$

Cotton Mill Operatives' Dwellings at Pedra $\ldots . \quad \ldots \quad 37$

Hydro-Electric Plant $\ldots$.

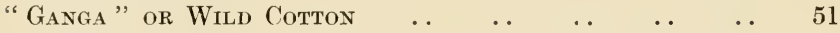

"Bolandeiro." Driving Arrangement of Ginning FaC-

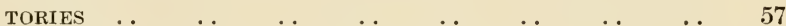

Cotton Ginned by Saw Gins and Roller Gins .. $\ldots .57$

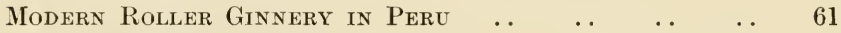

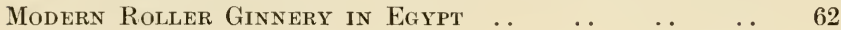

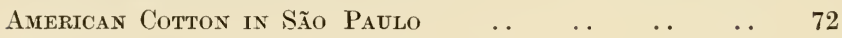

Snake Farm at Butantan $\quad \ldots \quad$.

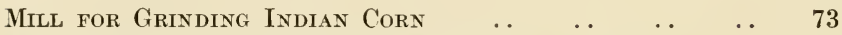

Weighing Cotton with Stone Weights $\quad \ldots \quad \ldots \quad \ldots 75$

A Cotton Field near Tatuhy $\ldots$.

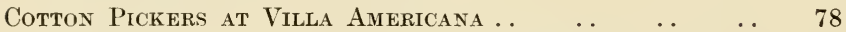

Transportation of Cotton at Villa Americana $\ldots \quad \ldots \quad 78$

Staple Lengths of Various Cottons grown at Villa

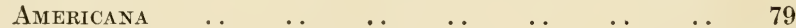

a Cotton Field at Villa Americana.. $\quad \ldots \quad \ldots \quad \ldots \quad \ldots \quad 81$

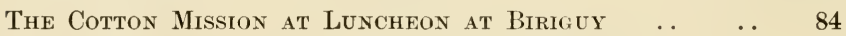

The Mission Riding Over the Estate at Biriguy $\ldots 85$

Clearing of Forests at Biriguy $\quad \ldots \quad$.

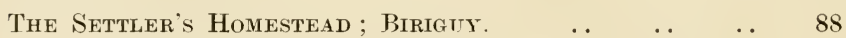

Coffee Plantation at "Sampaio Vidal "

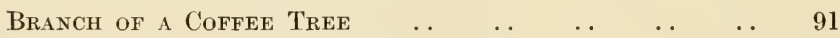

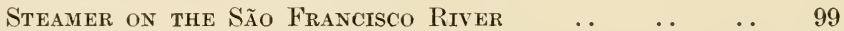

Primitive Hand-Screw Press for Cotton Bales .. .. 101

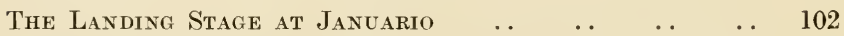

The Making of Pillow Lace $\ldots$.

View of the Banks of the São Francisco River a. 104

On the Lower São Francisco River . $\quad \ldots \quad \ldots \ldots 8$

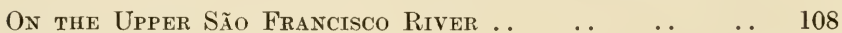

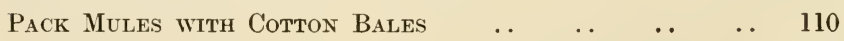

"Verdão" Cotton $\quad$ ".

Shipping on the São Francisco River $\ldots$. . $\quad \ldots \quad 115$

Market Scene at Sant' Anna $\ldots$. 
Motor Roads in the North-Eastern States

River-Bed Cultivation $\ldots$.

Crossing the River under Difficulties $\ldots$. . $\quad \ldots \quad 135$

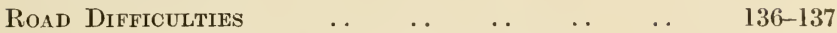

Fording a River in Rio Grande do Norte $\quad \ldots \quad \ldots \quad \ldots 138$

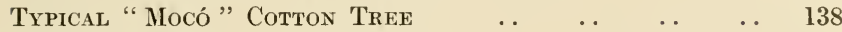

"Mocó " Сотton .

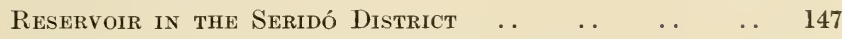

Typical Cotton Land in the Seridó District $\ldots . . .147$

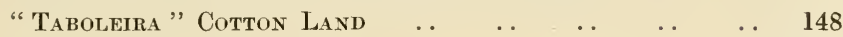

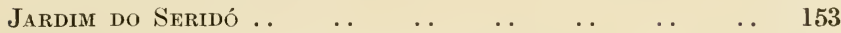

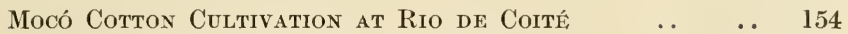

Mocó Cotton Field in the Valley of the São Bento River 155

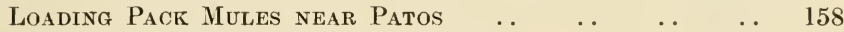

Cotton Haulage at Campina Grande.. $\quad \ldots \quad \ldots . \quad \ldots \quad 158$

Hydraulic Cotton Bale Press at Messrs. Kröncke \& Co.,

$\begin{array}{lllllllll}\text { Parahyba } & \ldots & \ldots & \ldots & \ldots & \ldots & \ldots & \ldots & 166\end{array}$

Cotton Sampling in the Streets of Parahyba $\ldots . .167$

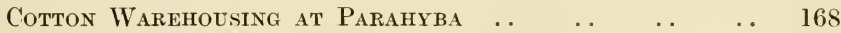

Sugar Cane Mill $\ldots \begin{array}{lllllllll} & \ldots & \ldots & \ldots & \ldots & \ldots & \ldots & \ldots & 179\end{array}$

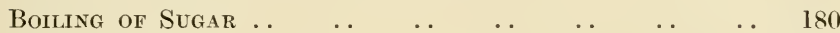

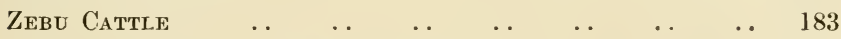

$\begin{array}{lllllllllll}\text { Mrlking } & \ldots & \ldots & \ldots & \ldots & \ldots & \ldots & \ldots & \ldots & 183\end{array}$

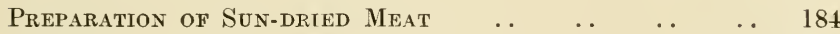

$\begin{array}{llllllllll}\text { Tobacco } & \ldots & \ldots & \ldots & \ldots & \ldots & \ldots & \ldots & \ldots & 187\end{array}$

Carnauba Palms $\quad \ldots \quad$.

\section{MAPS}

Coloured Map of Brazil _. . . A the end of the book

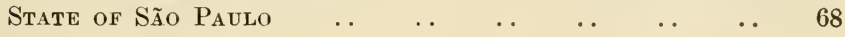

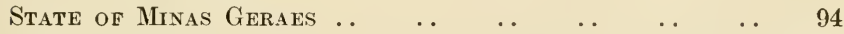

State of Bahi

State of Sergipe $\ldots \begin{array}{lllllllll} & \ldots & \ldots & \ldots & \ldots & \ldots & \ldots & \ldots & 119\end{array}$

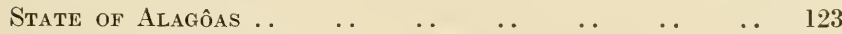

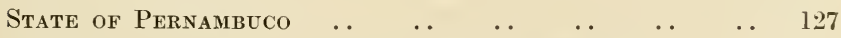

States of Parahyba and Rio Grande do Norte .. $\quad . \quad 132$

Seridó District $\ldots$.

Chart Showing Length of Staples of "Mocó” Cottons. . 165 


\section{BRAZILIAN MONEY, WEIGHTS AND MEASURES}

\section{MONEY :}

The basis throughout Brazil is the "real" (plural: "reis"), which is, however, not in circulation, being too small a coin. 1,000 reis are taken as the basis in exchange calculation; at the time of our visit 1,000 reis (one milreis) were equal to about $7 \mathrm{~d}$. The normal rate is $27 \mathrm{~d}$. One "Conto de reis" is used to indicate 1,000 milreis. The conto is generally expressed in writing by double dots between the figures, thus, 1:000\$000 (at the rate of 1 s. per 1,000 reis $£ 50$ ), meaning one conto.

\section{WEIGHTS :}

The metrie system is in force.

1 "arroba" = 15 kilos, sometimes 16 and even 20 kilos, especially in the North. Owing to the varying rates the equivalent in kilos is always stated in this report.

1 kilo $=2 \cdot 205$ lb. avoirdupois.

llb. $=0.453$ kilo.

\section{LAND MEASURES :}

1 alqueire $=5 \cdot 6$ acres $=\mathbf{2} \cdot 4$ hectares.

In São Paulo one alqueire $=100$ "braças" (arms) by 50 braças ; each "braça" $=\mathbf{2} \cdot 20$ metres $=10$ "palmas" (palm of hand); I "palma" =.22 metres. (In Rio and Minas one alqueire is equal to 100 braças.)

The metric system is in force.

In the North "Tarefas" are used. 1 tarefa $=30$ braças $\times 30$ braças (approximately an acre). 1 braça $=2 \cdot 20 \mathrm{~m}$.

Generally, the following rough and ready measures obtain :

48 to 55 kilos seed cotton give 15 kilos lint.

55 to 65 litres dry coffee in cherry state give 15 kilos of clean coffee beans.

3 parts of rice in hull give 2 parts cleaned.

1 cart of Indian eorn $=12$ loads $=24$ baskets $=20$ alqueires of 50 litres. (The word "alqueire" may mean a land measure or a weight.)

In the interior stones are still in use for weighing on the scales; frequently a few horses' or mules' shoes are added to the stones to adjust the scales. 


\section{INTRODUCTION}

During the visit of the Brazilian Commercial Mission to Europe in 1919, efforts were made to interest the European Cotton Spinning Industry in the cotton produced by Brazil and for this purpose Mr. Roberto Cochrane Simonsen, one of the members of that distinguished Mission, read a paper at the meeting of the International Cotton Committee at Paris, on the 4th September, 1919, dealing with the possibilities of Brazil as a cotton producing country. In concluding his address he invited this organisation to send out to Brazil a Mission with a view to studying the conditions obtaining in that country.

'I'he invitation was accepted at the Paris meeting and confirmed by the Tenth International Congress held at Zurich. The writer and Mr. Max Syz (of Zurich, Switzerland) left England on the 18th March, 1921, for Rio de Janeiro, where they were met by Mr. Fritz Jenny (of Ziegelbrücke, Switzerland) who had proceeded there direct from the cotton belt of the United States of America. (He had been engaged there in the study of American cotton.) These three constituted the European members of the International Cotton Mission to Brazil. Owing to the crisis in the European cotton industry it was impossible to increase this number. Several Brazilian Government officials accompanied the mission, and by invitation of the Governor of the State of Parahyba, representatives of the cotton export firms of Messrs. Kröncke \& Co., and Julius von Söhsten \& Co., took part in the tour through the North-eastern portion of Brazil.

His Excellency, Dr. Epitacio da Silva Pessôa, the President of the Federal Government of the Republic of Brazil received us on April 12th, 1921, at his palace, Rio Negro, Petropolis, and stated that he would like to see Brazil diversity her crops and that he would do everything he could in order to make cotton one of her large export products. His Excellency is a native of Parahyba, one of the cotton Statos of Brazil, and is well versed in cotton problems.

His Excellency, Dr. Ildeffonso Simões Lopes, Minister of Agriculture, Industry and Commerce, personally superintended the arrangements for our journey; he also kindly took the chair at my meeting in Rio de Janeiro.

We had the honour and privilege to be the guests of the Brazilian Government and thus we enjoyed the greatest facilities in our travels. Through the instrumentality of the various State Governments we had the advantage of reliable guides and were able to organise through the "prefeitos" (mayors) and "chefes politicos" (political heads), msetings with the cultivators wherever we journeyed. In this manner we came into close touch with the small and large cultivators. The Cotton Department of the Ministry of Agriculture at Rio de Janeiro delegated one of its officials to accompany us in each State and we had the advantage of having with us, for a portion of the journey, the Chief of the Cotton Department, Mr. William Wilson Coelho de Souza.

Unbounded hospitality was shown to us, not only by the Federal and State Governments, but also by the Mayors and all the inhabitants 
of the places visited by us, and I take this opportunity of again expressing the cordial thanks of the members of the Cotton Mission to all those who have helped in making our work a success. Without this exceptional assistance, given us so freely, we could never have covered the ground in so short a time, nor could we have harl access to the information we were able to collect.

In presenting this report of our journey through the principal cotton States of Brazil to the members of the International Cotton Federation, I deem it essential to deal first in a fow short chapters with the geography, history and general economics of the country, for without such details an intelligent comprehension of the cotton growing industry of that country appears to me difficult, if not impossible.

I have endeavoured to make this business report somewhat less "dry" than the customary documents of this kind, by introducing a large number of photographs, and by dealing with other subjects besides cotton. In short, the Report contains all the information which came to our notice during our journey, and it aims at taking the reader over the whole ground as if he had been a member of the Mission.

Those who desire to learn more on Brazil are referred to the following books :

Pierre Denis, "Brazil." T. Fisher Unwin, Ltd., London.

E. C. Buley, "North Brazil" and "South Brazil." Sir Isaac Pitman \& Sons, Ltd., London.

Clayton Sedgwick Cooper, "The Brazilians and their Country," William Heinemann, London.

J. C. Oakenfull, " Brazil." Bale, Sons \& Danielson, Ltd., London. Cincinato Braga, "Magnos Problemas Economicos de São Paulo," Secção de Obras d' "O Estado de S. Paulo," São Paulo.

E. Dettmann, "Brasilien's Aufschwung." Herm Paetel, Berlin.

H. Schüler, "Brasilien." Deutsche Verlags-Anstalt, Stuttgart.

E. von Hesse Wartegg, " Zwischen Anden und Amazonas." Union

Verlag, Stuttgart.

Economic Notes on Brazil, by the "Serviço de Informaçoẽs," Ministry of Agriculture, Rio de Janeiro.

The only book on Brazilian Cotton known to me was published during my visit by Mr. William Wilson Coelho de Souza, Chief of the Cotton Department of the Ministry of Agriculture, Rio de Janeiro, and is entitled "A Cultura do Algodoeiro no Brazil."

We arrived at Rio de Janeiro on 2nd April, 1921, and after paying official visits, collecting information from the Government Departments and inspecting a number of cotton mills, we proceeded to São Paulo, where we spent one month in the interior. Our journey then took us through the following States: Minas Geraes, Bahia, Alagôas, Sergipe, Pernambuco, Parahyba and Rio Grande do Norte. We covered in Brazil the following approximate distances :-

$$
\begin{array}{lllll}
\text { By Rail . } & . & \ldots & \ldots & 4,000 \\
\text { By Motor Car . } & \ldots & \ldots & 2,000 & , \\
\text { By River Boat . } & \ldots & \ldots & 1,000 & , \\
\text { On Horse Back } & \ldots & \ldots & 500 & ,
\end{array}
$$

returning from Pernambuco to Rio de Janeiro by steamer. The ocean 
journey was in all 11,000 miles.

Having travelled over such enormous distances in so short a time it is to be expected that some, I hope only slight, inaccuracies have crept into my Report: I trust that these will not be too numerous.

Owing to the shortage of time we were unable to visit the following States, which also produce cotton:-Piauhy, Ceará, Maranhão, Amazonas and Goyaz.

The method of collecting and imparting information consisted generally in inspecting the fields in each district and discussing later with the farmers, planters and merchants the various points at issue ; at many places we were able to hold meetings with the cultivators and to explain to them where their method of cultivation was at fault. With a view to interesting larger circles in the cotton problem I was asked by various Agricultural and other Societies to give lectures in the principal centres. Four of these were delivered in the cities of São Paulo, Bello Horizonte, Bahia and Rio de Janeiro. At these gatherings we had present representatives of the cabinet ministers, senators, deputies, cotton millowners, planters and merchants, and a wide publicity was given to the lectures in the Press. Various societies reprinted these lectures and distributed them in pamphlet form amongst the cultivators.

The paper which I read before the National Agricultural Society at Rio de Janeiro, at which the Minister of Agriculture took the chair, gives a synopsis of the impressions of the entire journey for which reason $I$ append a translation of it to this report (see pp. 210). Those readers who do not wish to study the Brazilian cotton question in detail will gather the main points from a perusal of this paper. The other three lectures dealt more especially with the conditions obtaining in the respective States.

The Brazilian Press gave daily reports on the progress of our journey, and dealt in many articles with cotton growing, thus contributing largely to the creation of a public interest in cotton.

Many of the photographs appearing in this Report were taken by Mr. Fritz Jenny, a member of the Mission.

Dr. W. Lawrence Balls, Chief of the Experimental Department of the Fine Cotton Spinners' and Doublers' Association, Ltd., Manchester, sub nitted a number of my Brazilian cotton samples from the Serido District to scientific tests in the laboratories of this firm, of which the results will be found in pp. 159/165. I herewith acknowledge my thanks to Dr. Balls and to the Fine Spinners' Association.

This Report was submitted in proof form to the meeting of the Committee of the International Cotton Federation, held at Paris, October 12th, 1921, when the following resolutions were unanimously adopted :-

The Committee of the International Cotton Federation, having received the Report of the General Secretary on the recent journey of the International Cotton Mission to Brazil, expresses the opinion that several of the States visited, especially São Paulo, Purahyba and Rio Grande do Norte, are eminently suitable for cotton growing. 
The Committee trusts that the Brazilian Federal Government and the Governments of the various States will take the necessary steps for improving and extending colton cultivation, especially by establishing seed farms and by the distribution of pure seed of one variety only in each district, to assure uniformity of fibre.

The Committee expresses the opinion that the establishment of roller-gins in the North-Eastern States of Brazil would materially contribute towards preventing deterioration of the fibre, that it uould improve the quality of the cottons delivered to the spinners and cause a commensurate increase in their prices.

The Committee recommends the establishment of such ginning factories as an industrial undertaking to the mutual advantage of grower, ginner and spinner.

The Committee is of the opinion that Brazilian cottons are not sufficiently known, and recommends to the members of the Federation to make trials with Brazilian cotton.

The Committee of the International Fcderation of Master Cotton Spinners' and Manufacturers' Associations desires to express to the Brazilian Federal Government, to the Governments of the States of São Paulo, Minas Geraes, Bahia, Alagôas, Sergive, Parahyba, and Rio Grande do Norte, and to the Municipalities visited by the International Cotton Mission, its cordial appreciation and than $\mathrm{l}$.s for the unstinted generosity shown and the many facilities granted to the members of that Mission.

The Committee also records its thanks to all those who have sc, generously assisted the Mission in its uork.

These Resolutions, along with the whole Report, will be discussed at the forthcoming Eleventh International Cotton Congress which the International Cotton Federation will hold on 14th to 16th June, 1922, at Stockholm.

With a view to bringing the Brazilian cotton question more to the attention of those interested in cotton I proposed to the Brazilian Government, during my stay in Brazil, the convening of a Cotton Conference at the time of the Independence Centenary Festivities, which Brazil is celebrating in the autumn of 1922 . This suggestion has been acted upon and a Cotton Conference, which will be given an international character, is being organised by the "SocIEDADE Nacional de Agricultura," under the auspices of the Brazilian Government, full particulars of which will be found at the commencement of the advertisements at the end of this book.

ARNO S. PEARSE, General Secretary. 


\section{Chapter I.}

\section{GEOGRAPHY}

The most erroneous ideas exist in the minds of many Europeans as to the geographical conditions of Brazil.

The Federated States of Brazil, twenty in number, besides the Territory of Acre and the Federal District, are almost a world in themselves and form the Eastern part of South America. The area they occupy corresponds to $\frac{1}{15}$ th part of the whole of the world. Brazil is almost half the size of South America, 300 times as large as Belgium, 15 times as large as France, and almost as large as the whole of the United States of North America, with the exception of Alaska. Only Great Britain and China may boast of possessing a larger territory under their flags than Brazil, but Brazil has this advantage that it forms one complete whole, not separated by other territory.

Brazil's boundaries touch British, French and Dutch Guianas, the Republics of Venezuela, Colombia, Ecuador, Peru, Bolivia, Paraguay, Uruguay and Argentine. The only South American country which does not border on Brazil is Chili. Brazil's coast line on the Atlantic Ocean is $7,920 \mathrm{klm}$. (over 5,000 miles), whilst the total area is stated to be $8,524,776$ square kilometres $(3,292,000$ square miles).

The Density of Population is very low, for the total number of inhabitants, according to the latest census of 1920 , is only $30,553,509$, or $9 \cdot 3$ per square mile. This factor is the one great impediment in the more rapid development of the country.

POPULATION OF BRA7IL FOR THE YEARS 1913, 1914, 1915, 1916 AND 1917

\begin{tabular}{|c|c|c|c|c|c|c|}
\hline STATES & SQ. MILES & 1913 & 1914 & 1915 & 1916 & 1917 \\
\hline Alagôas .. & 22,583 & 867533 & 886,966 & 906,834 & 927,147 & 946,617 \\
\hline Amazonas & 732,439 & 394,713 & 411,646 & 429,306 & 447,147 & 459,309 \\
\hline Bahia & 164,643 & $2,795,879$ & $2,846,205$ & $2,897,437$ & $2,949,591$ & $3,013,007$ \\
\hline $\begin{array}{lll}\text { Ceará } & \cdots & \end{array}$ & 40,247 & 1198,536 & $1,218,192$ & $1,238,170$ & $1,258,476$ & $1,291,574$ \\
\hline Districto Federal . . & 538 & 984,370 & 964,201 & 961,822 & 937,961 & 908,819 \\
\hline Espirito Santo . . & 17,312 & 376,326 & 390,777 & 405,783 & 421,365 & 434,512 \\
\hline Goyaz $\quad \ldots$ & 288,536 & 439,892 & 451,417 & 463,244 & 475,381 & 487,646 \\
\hline Maranhão.. & 177,561 & 696,019 & 708,617 & 721,443 & 734,501 & 748,971 \\
\hline Matto Grosso & 532,683 & 196,344 & 201,685 & 207,171 & 212,806 & 215,807 \\
\hline Minas Geraes & 221,951 & $4,714,644$ & $4,802,336$ & $4,891,659$ & $4,982,644$ & $5.064,858$ \\
\hline Pará $\quad \ldots \quad \ldots$ & 443,903 & 833,292 & 857,374 & 882,152 & 907,646 & 922,622 \\
\hline Parahyba do Norte & 28,854 & 639,561 & 649,090 & 658,761 & 668,577 & 682,350 \\
\hline Paraná $\quad . \quad \ldots$ & 85,451 & 575,189 & 596,183 & 617,944 & 640,499 & 661,252 \\
\hline Pernambuco & 49,573 & $1,681,509$ & $1,714,635$ & $1,748,413$ & $1,782,857$ & $1,827,071$ \\
\hline Piauhy $\quad$. & 116,523 & 449,736 & 458,281 & 466,988 & 475,861 & 483,094 \\
\hline Rio de Janeiro $\quad$. & 26,632 & $1,347,276$ & $1,368,967$ & $1,391,007$ & $1,413,402$ & $1,446,193$ \\
\hline Rio Grande do Norte & 22,195 & 432,752 & 441,364 & 450,147 & 459,105 & 473,659 \\
\hline Rio Grande do $\mathrm{Sul}$ & 91,333 & $1,715,342$ & $1,748,580$ & $1,782,461$ & $1,817,000$ & $1,852,207$ \\
\hline Santa Catharina .. & 29,632 & 475,875 & 488,057 & 500,551 & 513,365 & 526,404 \\
\hline São Paulo .. . . & 112,307 & $3,845,404$ & $3,996,144$ & $4,152,793$ & $4,315,582$ & $4,466,196$ \\
\hline Sergipe $\quad \ldots \quad \ldots$ & 15,093 & 432,968 & 439,809 & 446,758 & 453,817 & 462,757 \\
\hline \multirow[t]{2}{*}{ Territorio do Acre.. } & 73,009 & 91,491 & 93,227 & 94,998 & 96,807 & 98,654 \\
\hline & $3,292,000$ & $25,184,651$ & $25,733,753$ & $26,315,842$ & $26,891,537$ & $27,473,957$ \\
\hline
\end{tabular}

Total for $1920: 30,553,509$ 
The largest number of people are found along the coast.

Though the number of inhabitants may be small in comparison to the size of the country, yet we must have regard to the rate at which it has grown during the last 50 years in order to realise the developments which are taking place in this country. In 1872 the population was stated to be $10,123,054$, in 1890 about $20,000,000$. For the years 1913-1917 we have the statement of the Director General of Statistics.* (See Table, page 13). This table shows that during the last three years, an increase of three million people has taken place out of a total increase of ten millions in thirty years.

The Brazilians are a very prolific race. Every European visiting Brazil is surprised to find such large families, 10 in number is quite a common occurrence, and in the North, especially in Ceará, families of 20 are frequently met with.

Many Europeans have the impression that Brazil is populated by black races. This is not the case. Although exact statistics as to the number of coloured people are not available, it suffices to say that the blacks are merely the remnants of the African slaves who were introduced into Brazil shortly after its discovery in the early part of the sixteenth century. We now meet them mostly in the sugargrowing regions, especially in the districts of Pernambuco, Bahia and Campos, where their forefathers had worked as slaves. A number are also found in Rio de Janeiro, but in the interior of the other States the negro is searce and performs generally low menial work. There is absolutely no colour question in Brazil, the white and black are on an equal footing. Brazil, before the Portuguese occupation, was inhabited not by negroes but by Indians, whose skin ranges from dark brown to light brown, almost yellow, and if one may speak at all of a Brazilian race one can probably say with some justification that the Portuguese immigrants and the women of the Indian tribes laid the foundation of it as far back as the mediæval ages. Then came admixture with the Spanish, Dutch and French, during their various occupations of parts of Brazil. The African slaves have also left distinct traces in the race. The effect of the Dutch occupation is visible not only in the construction of the houses in parts of the North but in many of the northern races, for one notices there blonde people with blue eyes and perfectly white skins. Sometimes two or three children of a family are quite European whilst the rest show the Indian-Portuguese or even the negro type.

Portuguese is the official language and the Roman Catholic religion prevails throughout the Republic, though the State does not recognise it by subsidies.

Eighty per cent. of the nation are said to be illiterate, but enormous efforts are being made by the Government and most of the cotton mill owners and other industrials to remedy this evil through

*As a general remark applicable to all kinds of statistics for Brazil I wish to impress upon the reader the necessity of regarding such figures merely as judicious estimates. The country is too vast and the means of communication are too few to ensure anything like a reliable set of statistics for the entire country. 
the establishment of day and night schools for adults and children. The educational movement of the masses is at present a very strong one.

Immigration has played a very important part in the last few decades in the formation of the nation, and owing to the unsettled condition of Europe it is to be expected that we shall witness a considerable movement towards Brazil, for it is a mighty land whose riches have hardly heen tapped and an increased population is sorely needed.

The Federal Government of Brazil recognises the value of immigration and by means of subsidies assists persons who are agriculturists and who arrive aecompanied by their families. The following facilities are given :-Reception at port of arrival, landing of persons and baggage, board and lodging. medical assistance and medicaments until after departure for the locality selected, transportation of persons and baggage by railway or steamer to destination, exemption from duty on baggage and agricultural implements, explanation and information through interpreters who speak various languages and accompany the immigrants to their destination if necessary. The Board of Immigration and Colonization keeps a register of those "fazendas" (estates) where agricultural labourers are required and in the State of São Paulo they supervise the labour contracts with a view to preventing unfair conditions being imposed. The immigrant is very fairly dealt with by the Government and has always the right to appeal to the Board of Immigration in case of dispute.

The Government has also established several colonial nuclei where lots of 25 hectares are sold at a price varying from 8 to 30 milreis per hectare. Immigrants who wish to build their own houses obtain provisional lodgings from the Board of Immigration and Colonization. Payment for the purchase of land begins after the third year and the total amount should be paid within five to eight years. The Government refunds to families of at least three persons over twelve and under fifty years of age the amount of their ocean passage, not in money, but by deducting it as payment in advance of the purchase price of the house, land and any improvements existing on the selected plot.

The composition of the immigrants as to nationality is not easy to ascertain, but the Colonization Department of the Ministry of Agriculture, Industry and Commerce stated early in the war that according to its information 116,150 German immigrants had reached Brazil between the years 1820-1912. Italians during the same period accounted for 1,327,808, Portuguese 885,351, Spanish 414,438. Thus the Germans occupy only the fourth in the list of immigrants. Russia supplied 92,413, Austria 75,774, Turkey and Arabia 16,396. Immigration is almost negligible as regards the Northern part of Brazil. The proportion of the foreign element to the inhabitants in the whole of Brazil is about 8 per cent. In the United States of America this figure is approximately 13 per cent. and in Argentine 30 per cent.

The following are the latest statistics published by the Bureau of Information of the Ministry of Agriculture :- 
COMPARATIVE TABLE OF THE NATIONALITIES OF IMAIGRANTS, FROM $1910 \mathrm{~T}() \quad 1920$

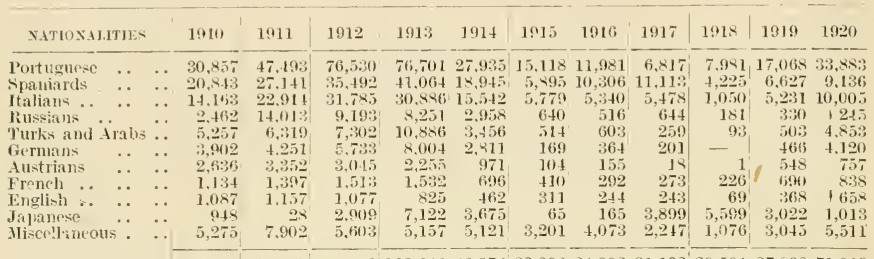

Total

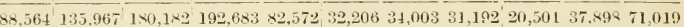

I have not come across the figures showing the number of foreigners who have again left Brazil. This item is specially heavy as regard the Italians, many of whom have been attracted by their eompatriots who have settled down in Argentine. And again many of the Italians have almost developed a nomadis trait going and coming every few years to and fro between Italy, Brazil and Argentine.

There is healthy and plentiful work in Brazil for every ablebodied man for many years to come. Anyone acenstomed to agricultural labour and willing to work will find a good living in the interior of Brazil. Many immigrants make, however, the usual mistake in settling in the eities, which are becoming over-erowded. In the State of São Paulo the Italian element is very pronounced, in the interior the work on the eoffee plantations is largely carried ont by them to the satisfaction of the "fazandeiros" (planters). and in the city of São Paulo the Italian immigrant makes an excellent cotton mill operative. I have been in mills where 60 per cent. of the workpeople were Italians. Altogether são Paulo is said to have more than 300,000 Italians: they learn the language readily, so much that Portuguese is often spoken amongst Italians and the second generation becomes Brazilian. The German colonist is held in high esteem amongst the Brazilians; it may be said that the war-hatred towards the German is no more existent. The highest officials, Brazilian business men and others seem to have made up their minds that the war is over and that the German element in Brazil bas been and will again be a great asset to the enuntry. The Spanish immigrant is not much appreciated by the eotton mill owners, as many of them try to stir up the workpeople to strikes and discontent; some mills refuse for this reason to engage Spaniards.

As regards the Climate of Brazil the most mistaken views prevail. The Brazilian elimate is generally judged in Europe to be most dangerous and detrimental to the health of Europeans. It is not suffieiently taught in omr schools that latitude is not the only deciling factor in climate. The prevailing winls and the altitude are causes which make the greater portion of the Brazilian elimate a very agreeable one. There is only a tropical temperature along the narrow coast line, which is a few feet above the sea level, but by far the greater portion of Brazil constitutes a range of plateaus seldom less than 100 metres and mostly ranging between 500-1,000 metres high; it is this tableland which interests us from a cotton point of view. 
The altitude of this vast tableland has necessarily a great cooling effect upon the temperature.

Though Brazil is situated entirely in tropical and temperate zones, the nights in the interior are always cool, and the atmosphere is dry and bracing, contrary to the coastal districts where there is always a certain amount of humidity.

The rate of mortality per 1,000 is perhaps the best documentary evidence of the healthy climate of Brazil and from the following particulars it will be seen that the rate of mortality even in the coastal towns compares favourably with many places in Europe:-

$\begin{array}{ccccc}\text { São Paulo } & \text { Rio de Janero } & \text { Bahia } & \text { Porto Alegre } & \text { Curity ba } \\ 20.8 & 20.7 & 18.1 & 21.3 & 14.9\end{array}$

Compare these with :

\begin{tabular}{|c|c|c|c|c|c|c|c|c|}
\hline \multicolumn{2}{|c|}{$\begin{array}{c}\text { ALEXANDRIA } \\
30 \cdot 0\end{array}$} & $\begin{array}{l}\text { Carro } \\
3 \pm \cdot 0\end{array}$ & $\begin{array}{c}\text { Moscow } \\
29 \cdot 0\end{array}$ & \multicolumn{2}{|c|}{$\begin{array}{c}\text { Trieste } \\
28 \cdot 1\end{array}$} & $\begin{array}{c}\text { MaDRID } \\
28 \cdot 0\end{array}$ & \multirow{2}{*}{$\begin{array}{l}\text { Naples } \\
25 \cdot 2 \\
\text { TURIN }\end{array}$} & \multirow{2}{*}{$\begin{array}{c}\text { BRESLAU } \\
23.5 \\
\text { VIENNA }\end{array}$} \\
\hline $\begin{array}{c}\text { Lisbon } \\
23 \cdot 1\end{array}$ & $\begin{array}{c}\text { GENOA } \\
21.5\end{array}$ & & $\begin{array}{l}\text { SEILLES } \\
21 \cdot 4\end{array}$ & $\begin{array}{c}\text { DUBLIN } \\
21 \cdot 2\end{array}$ & $\begin{array}{c}\text { MiLan } \\
21 \cdot 1\end{array}$ & $\begin{array}{l}\text { Roмe } \\
20 \cdot 8\end{array}$ & & \\
\hline & $\begin{array}{l}\text { oston } \\
18 \cdot 5\end{array}$ & & $\begin{array}{c}\text { W YORK } \\
18 \cdot 3\end{array}$ & & & $\begin{array}{l}\text { FRLIN } \\
17 \cdot 1\end{array}$ & 15 & \\
\hline
\end{tabular}

The foreigners in Brazil from whom Europeans generally obtain information are those engaged in commerce in the towns along the coast. Their horizon is very limited because few have had the opportunity and time to see the interior, for if ever they have a holiday they return to Europe; they are prone to generalise from the climatic and other conditions of the coast as to the rest of Brazil with a necessarily wrong result. In general, I must state that the information conveyed to us by Europeans resident in São Paulo, Rio, ete., as to certain parts of the interior has proved in almost every case erroneous. There is a lamentable lack of true knowledge amongst the European residents in the big cities as to conditions in the interior.

With regard to its climate, Brazil may be divided into three zones.

The first zone occupies the region lying in the vicinity of the Equator, and extends to the tenth degree of latitude south.

The second zone reaches from the tenth degree of latitude south to the tropic of Capricorn.

The third zone lies between the tropic of Capricorn and parallel $33^{\circ} 45^{\prime \prime}$, which is the southern limit of the Republic.

The characters of each of these zones are as follows:-

First zone : Mean temperature, 26 to 27 degrees Centigrade. The climate of the upper Amazon is warm and damp, the mercury oscillating between close extremes, except during what is called the "friagem " or cold spells. The middle part of the day is undeniably hot, but the mornings are cool and the afternoons are very bearable. Frequent showers cool and purify the atmosphere.

Second zone: Mean temperature, 23 to 26 degrees Centigrade in the low lands, and 18 to 21 degrees in the more elevated parts.

Third zone : Mean temperature, 16 to 19 degrees Centigrade. 
PARTICULARS OF CLIMATE OBSERTED AT TARIOUS PLACES IN BRAZIL

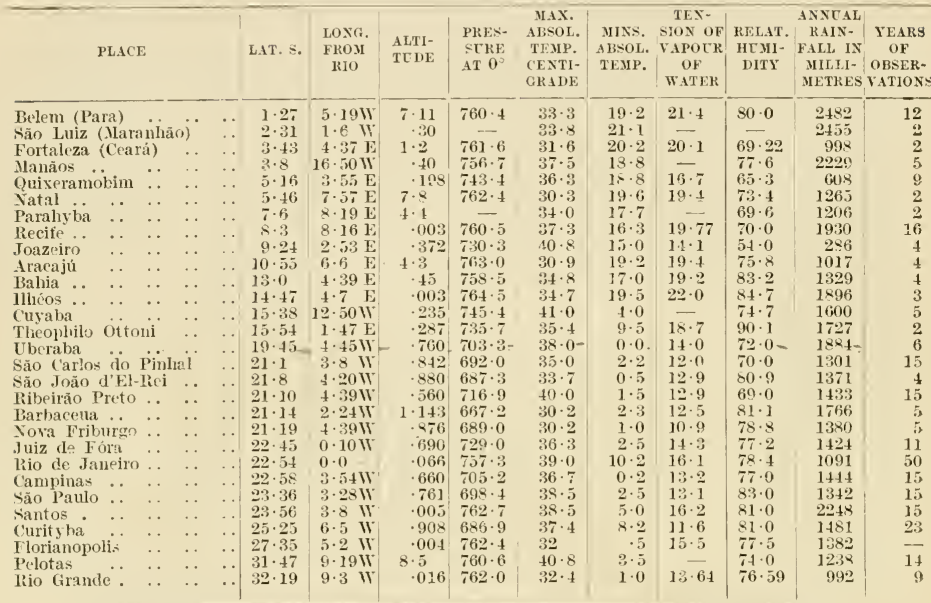

Waterways.-Steamship lines connect the prineipal ports of Brazil with many of the ports of Europe and the United States. Fifty trans-Atlantic liners are registered as touching these ports, but many of them continue southward to the Pio de la Plata and thus offer an international service in the South American sense of the word. Between Rio and Europe (most ports of Hamburg, Southampton, Havre, ete, to Lisbon) steamers two or three times a week are available, the time to or from Lisbon being 11 to 16 days. Italian and Spanish steamers go through the Straits of Gibraltar to Barcelona and beyond. Most steamers having Rio in their itinerary go also into the port of Santos, 200 miles south (322 kilometres), where the greater proportion of the Brazilian coffee is shipped, and through which the commerce of the State of São Paulo passes. The first port touched by some steamers is Pernambuco (Recife), 3,982 miles (6,408 kilometres) from New York, 4,065 miles $(6,542$ kilometres) from Liverpool. The city is one of the oldest settlements in Brazil, and shows the early Dutch influences. It is now being rapidly modernized, with new docks and harbour works, new avenues and many fine buildings. BAHIA $*$ is the first port on most sehedules. Pieturesque in the extreme, on the beautiful All-Saints Bay, it lies on the hills overlooking the harbour, second only to Rio and Victoria in beauty. Here, too, rapid progress has been marle in equipping the docks and in reconstructing the city, so that not only will the growing commeree be accommodated, but also the increasing stream of travellers will find that due provision has been made for their welfare. Bahia to Rio is 738 miles $(1,187$ kilometres), a pleasant two days' passage, intermediate ports being ports of eall for coasting steamers. Of these there are very many, some making only short runs from the home port, like Bahia, others

* S. Salvador in Portuguese. 
extending the service along the entire coast, and even to Manáos on the Amazon and Corumbá on the Paraguay. The ports touched by these steamers (and it is necessary to make use of them in order to reach these ports, except in the case of the Amazon and Paraguay rivers, where a foreign service is available) are Manáos, Belem (1'ará), São Luiz (Naranhão), Parahyba, Fortaleza, Natal, Cabadello, Recife, Maceió, Aracaju, Bahia, Victoria, Rio, Santos, Paranaguá, São Francisco, Itajahy, Florianopolis, Rio Grande, Pelotas and Porto dlegre. All coast shipping within Brazil has to be carried on under the Brazilian flag.

Brazil has been favoured by nature with a most wonderful system of fluvial arteries. It has within its territory not only the largest river basin, both in area and in length, in the world, but has also perhaps more navigable rivers than any other country. The mighty Amazon is navigable almost for its entire length, as are most of its affluents, while in the southern part of Brazil, the Paraguay, the Uruguay, and Paraná rivers are all navigable. The Picpublic has over 10,000 miles of navigable waterways open to river steamers and ocean-going vessels, and 20,000 miles additional which are navigable for light-draft and flat-bottom boats only. Several steamship companies maintain a regular service between points on these rivers, plying on the Amazon river, and on the Araguara river from the city of Belem (Pará) to inland points. The Guama. Tocantins, and São Francisco rivers also have regular steamer traffic: on the latter we travelled 11 days.

The Railways of Brazil at the end of 1920 measured 28,555,095 klm., or $15,346,934$ miles; they were distributed as follows :-

BRAZILIAN RAILWAYS IN THE VARIOUS STATES December 31st, 1920

\begin{tabular}{|c|c|c|c|c|c|c|c|}
\hline \multicolumn{4}{|c|}{ STATES } & KIIOMETRES & STATES & \multicolumn{2}{|r|}{ · KILOMETRFS } \\
\hline Amazonas & . & . & . & 8,281 & Espirito Santo . & . & 609,376 \\
\hline Pará ... & .. & . & . & 398,182 & Districto Federal . & . & 173,896 \\
\hline Maranhão & . & . & . & 412,352 & Rio de Janeiro & . & $2,620,344$ \\
\hline Piauhy . & .. & . & . & 26,000 & Minas Geraes & $\cdots$ & $6,613,793$ \\
\hline Ceará .. & . & . & . & 932,494 & São Paulo .. & . & $6,656.772$ \\
\hline Pio Grande & do Nor & & . & 323,329 & Paraná $\quad .$. & . & $1,110,267$ \\
\hline Parahyba do & Norte & . & .. & 328,822 & Santa Catharina. & . & $1,074,568$ \\
\hline Pernambueo & . & . & .. & $\$ 32,448$ & Rio Grande do Su & . & $2,701,738$ \\
\hline Alagôas & . & . & . . & 326,801 & Matto Grosso & . & $1,167,035$ \\
\hline Sergipe. & . & . & . & 298,923 & Goyaz $\quad$. & . & 181,779 \\
\hline Bahia .. & .. & . & . & $1,757,89.5$ & Total & $\ldots$ & $28,555,095$ \\
\hline
\end{tabular}

Some of these lines belong to the Federal Government, others to various State Governments : about $6,000 \mathrm{k} / \mathrm{m}$. are owned by private companies and about $10,000 \mathrm{klm}$. are leased.

The progress of railway construction is shown by the following figures:-

$\begin{array}{cccc}1854 & 1860 & 1870 & 1880 \\ 14,500 & 222,696 & 74+, 922 & 3,397,892 \\ 1890 & 1900 & 1910 & 1920 \\ 9,973,087 & 15,316,400 & 21,325,501 & 28,555,095\end{array}$

klm. rails constructed, 
The railways of Brazil were originally established with the purpose of bringing the products of a contributing interior territory to the nearest seaport and of distributing to the interior the merchandise brought in from abroad. On the Atlantic coast, Recife (Pernambuco) is the focus of one system, São Salvador (Bahia) of another, Rio de Janeiro of a third; São Paulo and Santos (the eoffee region) of a fourth, and Rio Grande do Sul, in the extreme south, of a fifth system. In recent years the Government has felt the great need of connecting these various systems by interior railways running north and south, both to afford interior communication independent of the ocean and to stimulate an internal commerce and settlement. This plan has been successful north and south of Recife, so that to-day it is possible to travel by rail between the ports of Natal and Maceió, in like manner Rio de Janeiro has been connected with São Paulo, Porto Alegre, and Rio Grande do Sul, and also with the growing port of Victoria, north of the eapital. South of São Paulo, through the States of Paraná, Santa Catharina, and Rio Grande do Sul, toward the Uruguayan frontier, connection is established between the lines in these States and those of Uruguay, so that it is possible to travel by rail from Rio de Janeiro to Montevideo, a total length of 1,967 miles $(3,165$ kilometres). The Federal eapital as well as the larger cities are served by electric street cars. The many streams in the Republic are capable of furnishing an enormous power for electrical purposes, and it is definitely decided to eleetrify certain portions of the railway lines already in existence. ("Brazil" Pan American Union, Washington D.C.)

Characteristics of Brazilians.-Before concluding this chapter on the geography of Brazil it may be advisable to eite some of my impressions of the charaeteristics of the people.

The Mohammedan influence on the Portuguese is more strikingly noticeable in the interior of Brazil than in Portugal, especially in the home life and in the attitude towards women. Family life is a great institution in the comntry; near and distant relatives, rieh and poor, frequently share the same house, indeed a wealthy Brazilian will consider it an honour to help his or his wife's poor relations, just as is the ease in the Orient. Hospitality to relative or stranger reigns supreme in Brazil.

Brazilians are a very sober race, exceptionally little drunkenmess is seen in town or country.

The Brazilian workman, under suitable guidance, is good; he picks up easily anything properly explained to him and though at times given to indolence, employers generally are quite satisfied with the labour. It would seem to me, judging from our long motoring experience, that the ordinary Brazilian has a bent for mechanies, for in almost every village one is sure to find somcone able to drive a Ford ear and what is more, able to take it to pieces and put it together again. Brazilians, as a rule, are exeellent drivers of motor-cars.

As regards business eapabilities, there are two extremes, one very active, eager and enthusiastic, frequently too much so, and the other indolent, phlegmatic, similar to the Moliammedan aneestors who eame to Portugal from the North African coast. There is hardly any distinet seetion between these two classes. It is probably due to the want of continued application and eool commercial intelligence that many Europeans are engaged in commerce in Brazil. The many lotteries 


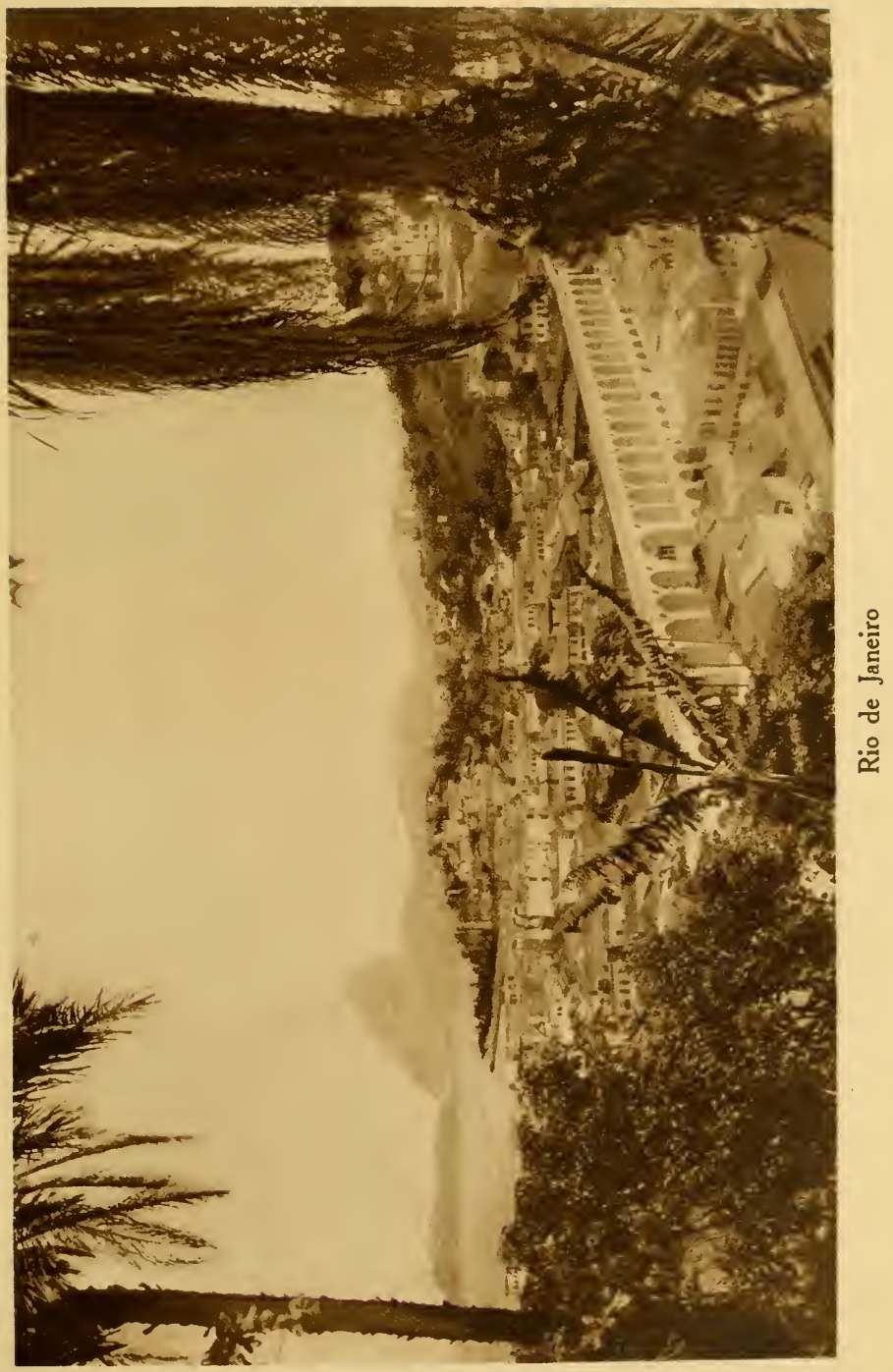




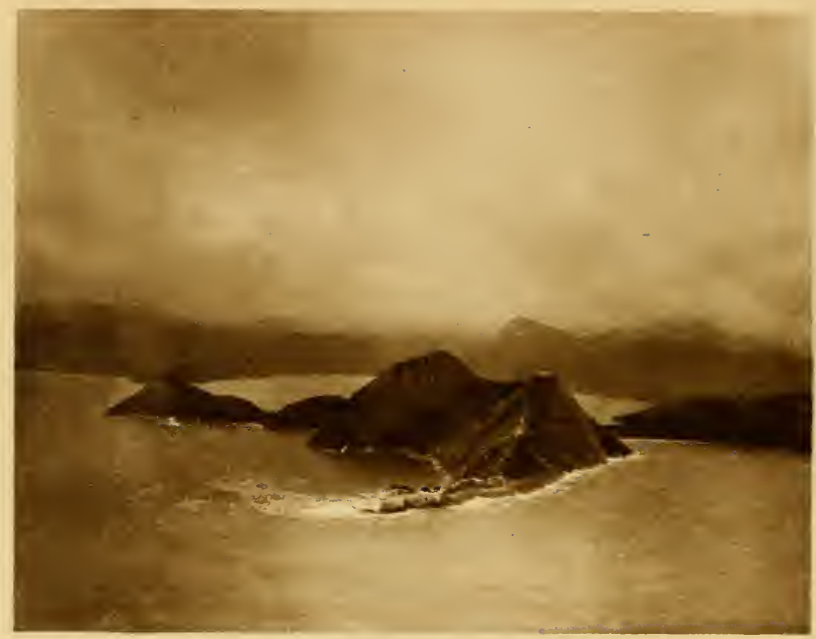

View from Sugar Loaf at Rio de Janeiro

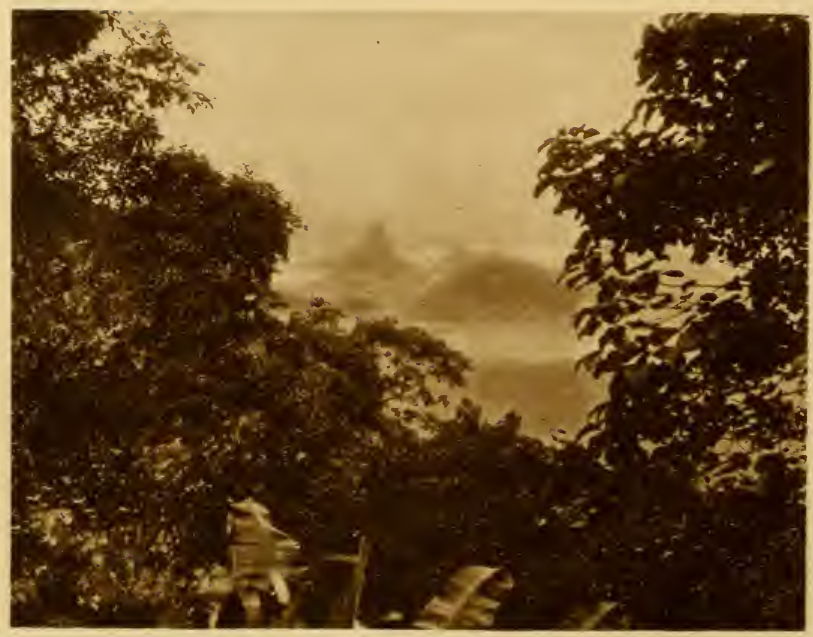

View of the Sugar Loaf 
that exist seem to have created a speculative instinct not only anong the commercial men, but also among the other classes.

The enthusiastic Brazilian does not lack in enterprise, nor in initiative; he takes a long view of things, spends money easily, but is perhaps at times given to over-trading. The worker in the country is frugal and knows no luxuries, whilst for the inhabitants of Rio de Janeiro or São Paulo no finery or comfort is too much. Probably Rio de Janeiro can boast that there is no other city so beautifully situated and that in no European town is so much attention given to dress by men as well as women.

French customs seem to prevail in Rio and many Brazilians speak French, but of late English has come to the fore in commercial quarters; many Brazilians have attended universities in Germany. In these travels it has often been brought bome to me how shortsighted universities and schools are by charging double fees to foreigners, for there is a sympathy, a bond of friendship and esteem created in the heart of the foreign student towards all those connected with the place from whence he obtained his learning, such as no diplomat nor commercial traveller has the power to produce.

\section{HISTORY OF BRAZIL*}

Pedro Alvares Cabral, a Portuguese navigator, is usually given the credit of having cliscovered Brazil, when, on April 22, 1500, he landed not far from the present site of the eity of São Salvador (generally known in Europe as the city of Bahia). Cabral named the country "Terra de Santa Cruz," or "Land of the Holy Cross," and took possession of it in the name of the King of Portugal. In April, 1549, Thomé de Souza, the first Governor-General landed in Brazil. The country had then become known as Brazil from the red dyewood in its forests, which, at that time, was brought from the East and was commercially known as "Brazil wood."

The Portuguese Crown divided the country, making grants of land to Portuguese nobles, who were to settle and colonize and who received a number of Indian slaves in addition to the land. With Thomé de Souza came the first Jesuits, who succeeded in obtaining complete control over the aborigines. To prevent the Indians being enslaved by the colonists, the Jesuits recommended and fostered the importation of African slaves during the next two centuries.

Between the years 1555 and 1640 , the country suffered numerous invasions from the French, Dutch and British, who sought to gain a foothold on Brazilian soil. In the former year Admiral Villegaignon established a colony of French Huguenots on an island in the Bay of Rio de Janeiro, which island now bears his name. He maintained himself there until the year 1560. The Dutch, in the year 1631, took possession of Pernambuco and gradually extended their power orer a great portion of Brazil. Prince Maurice of Nassau was appointed governor of the Dutch possessions in Brazil in 1636; it was not until the year I648 that the Dutch were finally forced to abanclon the country.

In 1640 Brazil became a viceroyalty, with Rio de Janeiro as capital. When, early in the nineteenth century, Napoleon invaded Portugal, the ruler of the latter country Dom João, wisely retired to

* A good deal of this information has been taken from a small pamphlet issued by the "Pan American Union," Washington-D.C., entitled "Brazil." 
his South Ameriean kingdom. He left Lisbon under the escort of an English squadron. He arrived at Rio de Janeiro on March 8, 1808, with all his family and court. Dom João established schools and in general promoted the interests of his colony by declaring the Brazilian ports open to trade and abolishing the Royal Portuguese monopolies hitherto in force. His arrival was the great turning point in Brazil's history. When, in the year 1821, he returned to Portugal, he appointed his eldest son, Dom Pedro, regent of Brazil. Dom Pedro was in sympathy with the movement for independence from Portugal, and on September 7, 1822, he formally proclaimed Brazil to be independent, and was, on October 12, 1822, solemnly crowned as Emperor. Under his wise rule and that of his able prime minister, José Bonifacio de Andrade, Brazil prospered. Dom Pedro I. reigned for nine years; and on April 7, 1831, abdicated the throne in favour of his infant son, Dom Pedro II. A regeney was appointed, which continued until the year 1840, when the young Emperor became of age and was erowned. Dom Pedro II. reigned until the year 1889 , when the people of Brazil resolved to change their form of government from a monarchy to a republic. This was accomplished without bloodshed on November 15, 1889, when the Republic was proclaimed.

\section{CONSTITUTION AND GOVERNMENT}

Under the constitution adopted February 24, 1891, the Republic is a federal union of States. The Government is divided into legislative, executive, and judicial branches. The legislative power is vested in the National Congress which consists of the Senate and the Chamber of Deputies. The Senate has 63 members, three for each State and three for the Federal District, elected by direct vote for a term of nine years, but is renewed by thirds every three years. The Chamber of Deputies has its members elected for a term of three years in the same manner as the senators and in the proportion of one for every 70,000 inhabitants. No State, however, is represented by fewer than four deputies. Congress meets regularly every year on May 3 for four months but may be prorogued or called in extra session by the President. All male citizens able to write and over 24 years of age are entitled to vote.

The executive power is vested in a President, who receives a salary of 120,000 milreis gold per annum. He is assisted by a cabinet of seven ministers whom he appoints and who are responsible to him only. The President and Vice-President are elected for a term of four years by direct vote, and may not be re-elected for the term immediately following their own. The present President is Dr. Epitacio Pessôa. The ministries are :

1. The Department of Justice and Interior (Ministerio da Justiça e Negocios Interiores) maintains relations with the various States, has charge of the administration of the National Territories and of the Federal District, the public health, sanitation of ports, the Federal Courts, and such schools and institutes as are maintained by the Federal Government, such as the Polytechnical School, National School of Medicine, National Institute of Musie, National School of Fine Arts, National Library, the Oswaldo Cruz Institute, ete. 
2. The Department of Foreign Affairs (Ministerio das Relações Exteriores) is entrusted with the relations between Brazil and foreign nations, through the diplomatic and consular corps.

3. The Navy Department (Ministerio da Marinha) controls all matters pertaining to the Navy, the numerous naval apprentice schools in the various States, the Naval College, the Library of the Navy: and the Museum of Naval Warfare.

4. The War Department (Ministerio da Guerra) has charge of the standing Army; recruiting conscripts and the various training schools for them, the military college at Rio de Janeiro, the military school Porto Alegre, the artillery school, various schools for training officers, two powder factories, a cartridge factory, etc.

5. The Department of Communications and Public Works (Ministerio da Viação e Obras Publicas) controls the railways, both Government owned and private, the post offices, national telegraph and wireless stations, construction and maintenance of ports, irrigation works undertaken by the National Government, the waterworks, sewerage, the drainage of the capital and of towns in the National Territories, as well as other public works undertaken by the Federal Government.

6. The Finance Department (Ministerio da Fazenda) has charge of the national funds, the preparation of the annual budget, and the service of the public debt. The following bureaus and divisions are under its control: The Federal Treasury, custom houses, national laboratory, conversion office, national printing office, "Diario Official," bureau of commercial statistics, bureau for inspection and control of insurance companies, amortization office, and the Bank of Savings and Loans.

7. The Department of Agriculture, Industry and Commerce (Ministerio da Agricultura, Industria e Commercio) has charge of the national observatory, meteorological bureau, bureau of statistics, botanical garden of Rio de Janeiro, national museum, commercial museum, the lodging house for immigrants, the iron foundry at São João do Ipanema in the State of São Paulo, the departments of colonization and immigration, geology and minerology, and agriculture, the latter having agronomic stations and a number of experimental farms; the commission for the economic development of Brazil, which publishes pamphlets and data regarding the resources of Brazil and maintains agencies in Europe and America for their distribution; and the Federal Zootechnic Institute. In 1920 a special Federal Cotton Department was inaugurated, which has established a number of experimental farms in practically all the Cotton States.

The individual States are the owners of mines and of public land situated within their boundaries, except those areas which are used for the purpose of defence, fortresses, military purpose or for Federal railways. Each State has the right to make agreements which are not of a political character, to raise loans to give concessions for railways, land or mining purposes. The States are entirely independent with regard to internal government. The Federal Government can only step in in special cases such as political disturbances or to restore 
public peace. Some States have Upper and Lower Houses. Each State lias as executive leader, a President or Governor; these are elected by public vote for a period of three or six years.

The governments of the individual States have to attend to primary education, communal administration (especially the police), sanitation, immigration: means of communication such as railways, roads and ships are generally administered by the State and the Federal Government. The State looks after the trade, inclustry, agriculture, literature, arts and sciences.

Foreigners may, without being naturalised, own property and exercise all rights, except political. The constitution assures to the Brazilian and the foreigner who resides in Brazil the inviolability of freedom and the safety of person and property. Brazilians and foreigners are equal before the Law

It has been said that amongst all civilised countries there is no constitution so liberal as the Brazilian one as regards foreigners who desire to make new homes there.

Taxes.-The resources of the Federal Government are principally derived from the import taxes on foreign goods. The Custom House tariff is a complicated one. The increases or decreases (the latter very seldom) are made by altering the percentage which is payable in gold. Until recently the pound sterling rate was taken for the purpose of converting paper money into gold, but as this currency has suffered owing to the war, the Custom House authorities are insisting upon the payment of the gold percentage at the dollar rate of exchange. In the past year 55 per cent. of the fixed duties were payable in this way. Cotton goods, generally speaking, are subject to a very high duty, 55 per cent. of which is payable in gold, thus increasing the duty to considerably more than the original value of the goods. The rates vary according to the texture of the cloth.

The main source of revenue of each individual State is the ExPorT TAx which the Governments of the various States may fix without consulting the Federal Government. All products of agriculture or industry, which cross the boundary of the State pay certain rates fixed every year in accordance with the likely expenditure. If the commodity is sent from one State to another the same rate of " Export Tax" is levied as if it were sent to countries abroad, but when goods have to pass through various States, only the State of origin is allowed to charge export tax.

The rates of export tax on raw cotton of the various States will be found in each chapter dealing with the respective States. I have used my efforts to persuade the various Governments to reduce this export tax on cotton as much as possible and there is every likelihood that this demand will be conceded by granting reductions for wellginned and clean cotton, thus stimulating proper picking and ginning.

There is also a State Tax on every machine of ginning factories and other industries. Small indirect taxation by the individual States is levied by means of affixed stamps on almost every article one buys in the shops. This tax (called Consumer's Tax) is, of course, additional to the import duties. The latter go into the coffers of the Federal Government, whilst the former helps to swell the slender incomes of the various States. 


\section{Chapter II.}

\section{THE COTTON SPINNING AND WEAVING INDUSTRY}

Development. - The first cotton spinning and weaving mills are said to have been established in Minas Geraes as far back as about 1775. Shortly afterwards the States of Pará and Maranhão had also some small factories, if factories they could be called, for most of the looms were worked by hand and the driving force for the spindles was a "bolandeiro" (mule-driven mill).

A wise Portuguese Government had imported hand spinners and weavers from India for the purpose of teaching their handicraft and we saw on our journey, especially in the villages along the São Francisco, the hand staff, the spinning wheel and the hand loom, the latter of the most primitive kind, the shuttle being thrown first by the right then by the left hand. The hand gins used in the interior of Brazil are almost identical with the "churkah" employed in India and were probably brought over by the spinners from India. Large numbers of hand looms are said to be in existence in all those parts of Brazil where railways do not reach and it would be well to introduce an improved hand loom with fly-shuttle as, no doubt, a saving of time of 40 per cent. could be easily achieved.

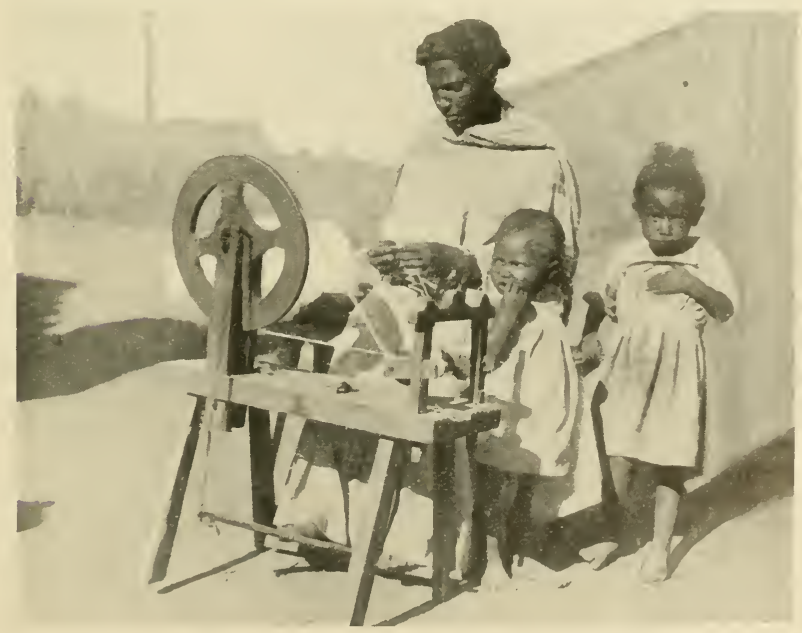

Spinning by hand is still in use in the Interior 
Some of the designs produced on the hand looms are quite artistic, especially as regards colour eombination. Generally vegetable dye is used by the weaver who dyes her own yarn. In Brazil hand looms are worked by women, at all events I have never seen a man work a hand loom, whilst in India this work is often done by men. I have a few small samples of the designs at the office for inspection.

The above mentioned early factory development of spinning and weaving was soon arrested by an Act of the Portuguese Government. The eotton millowners of Portugal had lost their home market in consequence of a treaty with Great Britain (Methuen Treaty) and were determined that they should, at all events, keep the market of their Brazilian colony for themselves. They persuaded the Portuguese

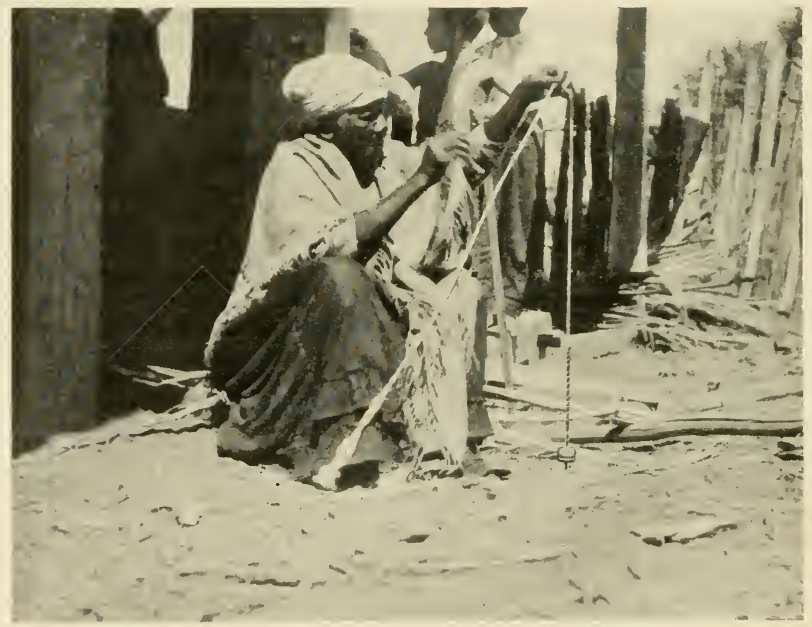

Hand Spinning in a village on the São Francisco River

Government to pass legislation prohiliting the manufacture of cotton cloth in Brazil, with the exception of the very commonest and coarsest eloth as used by the slaves. This act was passed in 1807 and rigorously enforced. When Dom João arrived in Brazil in 1809 his first measure was to open all the ports of Brazil to the mercantile fleet of the world (formerly only Portugal was allowed to trade with Brazil) and to foster the importation of all kinds of machinery; but again, a few years later, the existing Brazilian factories were obliged to return to the making of eoarse cloth only. This state of affairs continued until 1846. Though by the year 1822 Brazil had obtained its independence, no ehange was then made. It was only in 1846 that the Brazilian Government gave a number of concessions to factories, amongst which the free importation of machinery during ten years was the principal one. 
The following figures show the factory development which had taken place by 1866 :

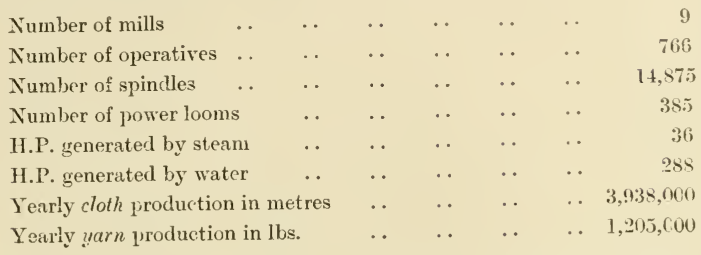

Bahia, the former capital, had most of the new mills. The development during the next 50 years is seen from the following table :

\begin{tabular}{|c|c|c|c|c|c|c|c|c|c|}
\hline & & & & & 1865 & 1875 & 188.7 & 1895 & 1905 \\
\hline Maranhão & .. & .. & .. & .. & -- & 1 & 1 & 16 & 10 \\
\hline Ceará & .. & .. & .. & .. & - & - & 1 & 4 & t. \\
\hline \multicolumn{3}{|c|}{ Pio Grande do Norte } & .. & .. & - & - & - & 1 & 1 \\
\hline Parahyba & .. & .. & .. & .. & - & - & - & 1 & 1 \\
\hline Pernambuco & & .. & .. & .. & - & J & 2 & 5 & 5 \\
\hline Alagôas & .. & .. & .. & . & 1 & 1 & 1 & 2 & 5 \\
\hline Sergipe & . & . & .. & .. & - & - & - & 2 & 2 \\
\hline Bahia & .. & .. & .. & .. & 5 & 10 & 11 & 11 & 11 \\
\hline Rio de Jane & iro & . & . & .. & 2 & 5 & 7 & 11 & 11 \\
\hline Federal Dist & trict & .. & .. & .. & - & - & 4 & 10 & 10 \\
\hline São Paulo & . & .. & $\ldots$ & .. & - & 6 & 12 & 10 & 18 \\
\hline \multicolumn{3}{|c|}{ Rio Grande do Sul } & . & .. & - & - & - & 2 & 2 \\
\hline \multicolumn{2}{|c|}{ Minas Geraes } & . & .. & .. & 1 & 5 & 10 & 37 & 30 \\
\hline \multicolumn{3}{|c|}{ Total number of mills } & .. & .. & 9 & 29 & 49 & 112 & 110 \\
\hline
\end{tabular}

These were all small concerns and few are worthy of the name of factory. The statisties of 1905 contain, however, only such mills as employed more than 50 operatives, whilst previous figures include all kinds of places where cloth was made. The average number of operatives in 1905 is given as 356 per factory.

During the last 15 years the Brazilian Cotton industry has grown hy leaps and bounds, aided by high import duties on foreign cotton good: and low rates of exchange which rendered the importation of foreign goods more difficult; another factor was, of course, the increase of population, due in a large measure to immigration since the abolition of slavery in 188s. Nuch more exact statistical data are available during this period and in the Appendix will be found full details of each factory, as to location, capital, reserves, power, operatives, looms, spindles and kinds of cloths produced. These figures relate to the year 1920 and are approximately correct. The "Centro Industrial de Fiação e Tecelagem," Rio de Janeiro, has supplied me with the following tabulation, showing the cotton factories as existing in Brazil during 1921: 


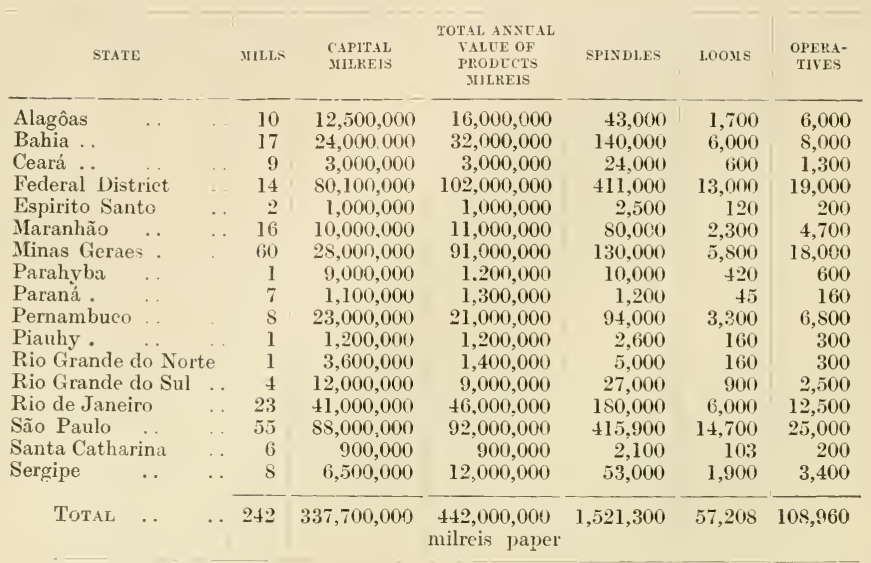

From this statement it would appear that Minas Geraes has still the largest number of mills, but from reference to the spindles column and to the detailed list in the Appendix it will be seen that the industry in Minas is insignificant in comparison with that of São Paulo and the Federal District.

If the rate of exchange of the milreis was any way near its par value-27d.-against its present rate-8d.-European goods would, no doubt, be able to compete with the national production, in spite of the excessively high tariff, but as it is, nothing but the very finest goods have a chance of competing with the Brazilian made goods. Twentyfive years ago Brazil was an excellent market for Manchester. I personally remember the time when a Manchester shipping house, in which I was employed, had weekly shipments of cotton goods of $£ 10,000$ for one Rio importer. There were then shipped all kinds of Greys, Whites, Prints and Fancies. First the Greys dropped out, and now all these goods are being manufactured in the country and only the very finest qualities remain to be imported. There are already some few concerns in Brazil which are spinning 80 's and higher, such as the "America Fabril," Rio de Janeiro, "The Agro Co.," Pedra, and Dr. Street of São Paulo, and these yarns are spun with cotton grown in the Serido, the North-East of Brazil; a few more mills spin up to $60^{\circ} \mathrm{s}$, but the bulk of the yarn produced averages about 18 's to 20 's.

Those countries which have been exporting in the past to Brazil will have to reckon with the times when hardly any cotton goods will be sent from Europe to this country, and if tley wish to have a share in the Brazilian market, they will have to open their own mills in Brazil, as Coats' have done. In view of the labour troubles which the European cotton industry has to contend with and in view of the heavy taxation in Europe, such a step may not seem an unwise one. A Belgian and a Dutch millowner are largely interested in a Prazilian 
cotton mill and the profits, as will be shown later, are decidedly encouraging.

Machinery, etc.- We visited, during our tour, a large number of cotton mills and were impressed with the modern mill architecture, the first-class machinery and in some of the mills with the high efficiency. But we inspected also some mills where the space between the machinery was very narrow, where the buildings were old and altogether unsuitable. We saw Platt Bros. machines of 1871 still at work. The fencing of machinery in most cases is not efficiently done. The spinning and weaving machinery is generally from well-known Lancashire machinists, though some Swiss makers had also supplied a number of ring frames. Only very few mules exist, the spindles being almost entirely ring spindles. Finishing and dyeing machinery is often of German make, whilst the Calico Printing machinery is mostly of Mather \& Platt, with a sprinkling of Alsatian machinery. Whilst there are, especially in Rio and São Paulo, mills which turn out cloth more or less as perfect as in Lancashire, there are a number of small mills in Brazil, especially in the interior, which produce eloth that could hardly be sold as "seconds" in Lancashire. The yarn used contains dirt, bits of leaves, foreign matter, and the cloth is therefore mneven. One Lancashire mill man had a pride in showing us how his looms "danced about," the floors of the mill being rickety and the transmission shaft running anything but true. But as he had made 300 per cent. profit in one year he did not see why he should improve his mill.

The great difference between a Lancashire and a Brazilian cotton mill is that in the latter not only spinning and weaving are carried on, but that there are also, in almost every case, departments for doubling, dyeing, finishing, bleaching and printing and that the variety of goods produced is of a very extensive range in every mill, as will be seen from reference to the list in the Appendix. The average counts spun are about 20's, but the "America Fabril," Rio de Janeiro, has now 30,000 spindles on fine counts and spins as fine as 125 's from Brazilian cotton, without admixture of any foreign cotton. This company is extending largely its fine spinning section.* Owing to the difficulties of transport, the Light \& Power Co. could not obtain during the war its imported insulating cords, but the "America Fabril" produced 26/100 plaited yarn and has done so ever since. This mill has now 130,000 spindles and is adding extensions from year to year. The able managing director, Mr. Nark Sutton, a Yorkshireman, is his own architect and is largely responsible for the development of the many departments. During the 32 years he has been in the country he has formed a high opinion of the Brazilian workmen and of Brazil as a first-class cotton growing country. Every mill in Brazil is bound to have a mechanic's, a carpenter's and joiner's shop of larger dimensions than is the ease in Europe. In three mills visited by us there were iron foundries, which had been installed since the war and not only are they used for repairs, but also for the construction of new heavy machinery. In one of these foundries we saw the sides of a raising machine of a German pattern being east. In one of the joiner's shops we watched a Brazilian making

* There are more than 40 English foremen engaged in the various departments. 
shuttles at the rate of one per hour; bobbins were also being made. All this work is new and has been started owing to the delays in delivery from Europe. Brazil has a store of magnificent hard woods and there is no reason why shuttles and bobbins should not be made there. Caustie soda, which is so much used in bleaching, is now often produced in the mill in vats which were cast in Brazil.

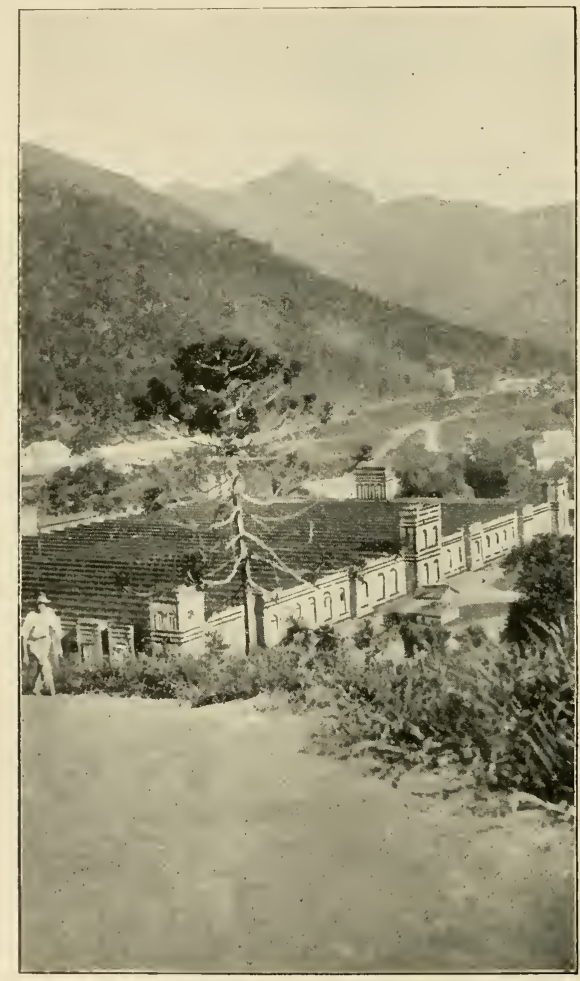

Cotton Mill near Petropolis

(Rio de Janeiro)

As mentioned before almost every mill aims ai providing social comfort to their workpeople, but it is especially in the direction of schooling that a good deal of work is donc. In one of the mills which has a large printing department, special art elasses were held, besides ordinary educational classes. Some excellent original work had been done by these young students who were qualifying as designers. 
At one or two mills a lithographic department was part of the establishment, all the tickets and stationery were printed there. A descriptive book with coloured illustrations of the mill had been entirely produced in this department.

Weaving.-The following is approximately the speed at which looms are worked:

$$
\begin{array}{llll}
36^{\prime \prime} & 210 & \text { picks. } \\
40^{\prime \prime} & 203 & \\
48^{\prime \prime} & 176 & , & \\
37^{\prime \prime} & 164, & \text { (automatic). }
\end{array}
$$

The efficiency was generally stated as being from 65 to 70 per cent. of the theoretical maximum, but one manager gave it as 50 per cent. only.

As a rule two looms only are given to a weaver, as with more looms to a weaver the mill loses, but in some mills the experienced hands work three looms.

Mr. Manoel Guedes' mill at Tatuhy has l2 special belting looms which turn out excellent belts.

Cotton Used.- Cotton is bought by the southern mills in Rio or São Paulo from merchants and brokers. Some of the northern cotton merchants have their own agents in Rio.

Practically all the mills in the South and in Bahia use some cotton from Pernambuco, Parahyba and Rio Grande do Norte. One millowner near São Paulo, who has a reputation as a cotton expert, was buying Pará and Ceará cottons, $1 \frac{1{ }^{\prime \prime}}{8}$ staple, as in his opinion it gave 2 per cent. less waste than Pernambuco cotton, and he liked Ceará cotton on account of the creamy colour. The quantities of cotton shipped from the north to Rio and Santos (for use in S. Paulo) are very considerable. In all the mills which we visited we made a close inspection of the cotton stores and were surprised to see that many mills in the South imported Pernambuco cotton for the spinning of 24's to 30 's, whilst they had cotton growing in the neighbourhood which we considered perfectly good enough for these counts. Indeed one cotton merchant told us that he had sent part of one lot of S. Paulo cotton to Germany where they had spun 32 's, whilst the same cotton in S. Paulo was used for 18 's. The southern mills have got into the habit of mixing 25 to 50 per cent. of northern cotton with S. Paulo cotton. We feel convinced that if the picking of cotton in S. Paulo were earried out more carefully and the dirty and clean cotton were separated there in the same manner as Boxwells, Kroncke, von Söhsten, and Vasconcellos perform this work in the north, the spinners of the South would not have to have recourse to buying the northern cotton. except those few concerns which spin 60's and higher, thus not only saving considerable expense in freight but also the export duty of the northern States. From Pernambuco to a neighbouring town of the eity of S. Paulo the freight and charges came to $\$ 8.000$ per 15 kilos= Rs.240 per 1b. One mill had bought at 26.9009 per 15 kilos ginner cotton, f.o.b. Pernambuco. At that time the price for a similar quality of S. Paulo cotton was $21 \$ 000$ to $22 \$ 000$. This compares with $34 \$ 000$ for Pernambuco cotton. It is true the São Paulo cotton might have given slightly more waste than the Pernambuco cotton. 
If the cotton spinners of the South were to encourage the farmers of São Paulo with fixed premiums for clean cotton, I feel convinced that they would ultimately be the gainers. In this connection I may be permitted to state that it appeared to us, that few millmen really took the trouble to examine their cotton ; in several cases the man in charge told us simply that the cotton in a certain shape of bale (it was from Boxwell's and speaks well for their reputation) was always right and that he has no need to examine it.

Nothing but Brazilian cotton is used by the mills in Brazil. There have been exceptional cases when odd lots of foreign cotton were imported, because the exchange was favourable and the northern cotton was in good demand by Europe.

Occasionally we found damp cotton in the mill stores and one manager told us that his cotton loses on an average 5 to 6 per cent. owing to evaporation. We could not get any detailed information on this point.

As regards the waste which Brazilian cotton gives, a millowner who spins 28's as average and is a careful expert told us that Pernambuco cotton gives 9 per cent., Ceará and Pará 7 per cent. in the opener. In the whole mill the waste was 10 per cent.

In another mill in S. Paulo (where they spin up to 60's without combing from cotton raised in the State) the waste during 1920 averaged $13 \frac{1}{2}$ per cent. In the opinion of a technical manager São Paulo cotton gives 8 per cent., Pernambuco 12 per cent., Natal 18 per cent.

The working week in Rio and São Paulo consists of 48 hours, but in the interior 50 and more hours are worked. In a few cases mills were working two shifts during the crisis.

Children are not supposed to work before they are 14 years of age, but in one mill in the interior we saw children of 11 years of age at work.

Workpeople receive compensation, according to law, in case of accidents.

Wages.-The following detailed wages were in force at one of the representative mills in the city of São Paulo during May, 1921, when the exchange was about $7 d .=1,000$ reis; they may be taken as a fair average of wages throughout the South of Brazil :-

\section{SPINNING DEPARTMENT}

$\begin{array}{rlllll}\text { OpenER } & \ldots & \ldots & \ldots & \text { Rs. } & 675 \text { and } 700 \text { per hour. } \\ \text { Cards : Tenter } \ldots & \ldots & , & 725 & \text { per hour. } \\ \text { Lap Carrier } & \ldots & , & 675 & , & , \\ \text { Can Carrier } & \ldots & , & 550 & , & ,\end{array}$

\section{Preparation :}

Drawing Frame: No. 0,14 hank sliver Rs. 345 per hank

$\begin{array}{lllll} & 0,16 \quad,, & , 315 \quad, & \\ , & 0,20 \quad, & , & 270 \quad, & \text {, }\end{array}$

1 female operative $3 \times 6$ deliveries. 
Preparation :-(rontinued).

Slubbing Frame: No. 0,65 hank Ris. 690 per hank.

$\begin{array}{llllllll} & , & 0,75 & , & , & 660 & , & , \\ & , & 0,90 & , & , & 630 & , & , \\ \text { Intermediate : } & & & & , & 725 & , & , \\ \text { Roving Frame : } & , & 3,00 & , & , & 760 & & \\ & , & 4,00 & , & , & 760 & & \\ & , & 5,50 & , & , & 820 & \end{array}$

Ring Spinnine: (A girl in the Ring room attends to 3 sides, altogether 660 spindles. At one mill in the interior the operatives of 14 years were not able to attend to more than 380 spindles.)

Ring Spinning Frames: Rs. $450-375$ per hour-one frame.

$$
\begin{array}{ccccc}
,, & 300-450 & , & , & \frac{1}{2} \text { frame according } \\
\text { to counts. } & \\
\text {, } & 250-300 & ., & , & \text { for Doffers. } \\
,, & 200-250 & . . & , & \text { for Apprentices. } \\
, & 450 & , & , & \text { one frame. } \\
\text {,, } & 325-375 & ., & , & \frac{1}{2} \text { frame. }
\end{array}
$$

Ring Dolbling Frames : , 450 ,, ,, one frame.

Reeling ANd Cross Winding: from $4 \$ 000$ to $5 \$ 000$ per day (piecework).

\section{WEAVING DEPARTYENT}

Warp and WeEt SPooling Frames: from Ris. $3 \$ 500$ to $4 \$ 500$ per day (Piece-work).

Warping Frames: from Ris. $6 \$ 500$ to $7 \$ 500$ per day (Piece-work).

Sizing Machines: Slasher .. $\quad \ldots \quad \ldots \quad$ Ris. $9 \$ 000$ per day. Labourer . . . . $\quad$. $\quad$,, $5 \$ 500 \quad$,, ,

Drawixg In: Female Operative from Ris. $4 \$ 500$ to 5.500 per day (piece-work).

\section{Ascistant : Half ahove wage.}

Loons (all piece-work) :

smooth coloured goods

Female weaver with 3 narrow looms $5 \$ 000-6 \$ 000$

Dobby (Ratières) , , , , , 2 , , , , $\quad 6,9000-7 \$ 000$

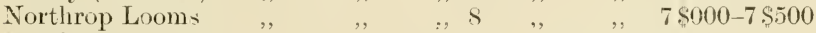

Northrop Looms : l _ , , , $16 \quad, \quad, \quad, \quad 1 \$ 600-2 \$ 000$

Box Looms : Female , , , 2 , , ,, 5\$500-6\$500

Double-width

Looms (with

$, 2 \quad, \quad .6 \$ 500-7 \$ 500$

Dobby or Box) I

7 Shuttles Jacquard Looms (for Quilts) :

One Male weaver per loom _. s s $\$ 000-9 \$ 600$

Weaving Foreman : per month (piece-work) . . . 300\$000-350\$000

\section{DYEING DEPARTMENT}

Dyers: from $7 \$ 000$ - $\$ \$ 000$ per day (piece-work).

FINISHING DEPARTMENT

Tentering and Calendering Machines, etc., from $6 \$ 500-7 \$ 000$ per day. 


\section{MAKING-UP DEPARTMENT}

Girls : from Rs. $4 \$ 500-5 \$ 000$ per day.

\section{IVASTE SPINNING DEPARTMENT}

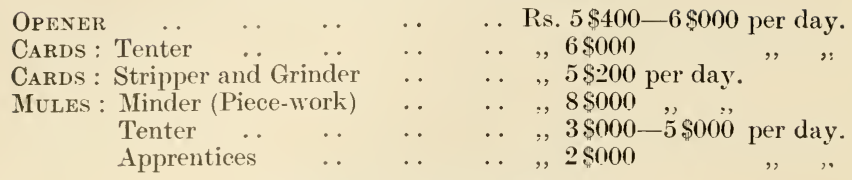

KNITTING DEPARTMENT

Spooling (Piece-work)

Female Wearers . . $\quad$. $\quad$..

$$
\begin{aligned}
& \text {. Ris. } 4 \$ 000-5 \$ 000 \text { per day. } \\
& \text {. , } 4 \$ 500-6 \$ 000 \text {,, ," } \\
& \text {. , } 4 \$ 000-7 \$ 000,, \quad \text {," }
\end{aligned}
$$

Since April, 1920, the Trade Unions and Works Committees are not recognised by the Masters' organisations.

Other wage particulars of Rio de Janciro and district are as follows :

Weaver : $5 \$ 000$ per day; at one mill the maximum was $9 \$ 000$, the minimum $2 \$ 000$, and the average worked out at $4 \$ 000$.

In the spinning room the wages varied from $1 \$ 500$ to $3 \$ 000$.

At a third mill the wages of the weavers were given as $6 \$ 000$, and those of a juvenile worker in the spinning room as $1 \$ 600$.

In the interior of São Paulo mill wages seem to be slightly different. Children of 14 years were earning over $2 \$ 400$ per day, men and women from $4 \$ 000$ to $4 \$ 800$. The same rates of wages are paid to male and female operatives for the same kind of work, and the managers of several mills told me that the women generally turn out more work than the men.

Printers' wages seem to be uniformally $10 \$ 000$ per day. We saw several machines printing eight colours. These rates of wages were fixed some time ago when the exchange was almost twice as high as at the time of our visit (April, 1921); no alteration has been made. In the towns food has advanced two or three times as much as before the war; clothing and rent are twice as high.

Pedra Mill-Besides Coats' Sewing Cotton mill in São Paulo there is a Brazilian undertaking-Companhia Agro Fabrit Mercantilat Pedra in the State of Alagôas, which produces a large range of sewing and embroidery cotton. The mill deserves special mention owing to the extraordinary pioneer work and enterprise which was required in its establishment, a work entirely initiated and carried out by a Brazilian, Mr. Delmiro Gouveia, a Cearense.

The cotton thread mill of Pedra is situated in the wild up-country, 24 kilometres (15 miles) from the Paulo Affonso Falls. We travelled to Pedra from Propria, which is close to the mouth of the São Francisco river by steamer, a journey of two days' duration, to a place called Piranhas. From there a slow railway took us in six hours to Pedra.

Prior to 1912 the present village of Pedra was a small hamlet containing only a few houses but the proximity of the huge waterfall 
suggested to Mr. Delmiro Gouveia, the idea of utilising this force for the purpose of establishing a sewing thread mill in competition with English yarns of this deseription, for supplying water for drinking and industrial purposes to surrounding villages, for erecting cotton seed oil mills and other industries and finally for supplying electric current to the country near and far. Pernambuco, Maceió, Bahia, etc., are within the range.

The "Paulo Affonso Falls" were acquired by this gentleman at the end of 1910, through the purchase of the land on both sides and a concession was given to him by the Government of Alagôas (Decree No. N.499, 29th December, 1910), according to which he had to undertake to grow cotton, cereals and fodder crops by means of irrigation, and to lay water-pipes for the free supply of drinking water to the population. On the other hand the Government of Alagôas granted him exemption from law of appropriation, exemption from Municipal and State Taxes on all irrigation machinery, cables, dynamos and for all other machinery necessary for the undertaking; further 40 per cent. reduction on the State Export Taxes on all agricultural produets; these advantages to expire in 1950.

The force which could be developed by this huge waterfall has been estimated by various people at about $1,000,000$ h.p., but a conservative calculation figures the available h.p., at the lowest waterlevel, at 600,000 . So far, one turbine of $750 \mathrm{h.p}$., one of 500 and a third of $\mathbf{2 5 0}$ are working and are ample for the present requirements. The large turbine is by Pickard Pictet, Geneva, and the two smaller ones by J. M. Voith, Heidenheim (Germany). A $24 \mathrm{~km}$. water-pipe has been constructed for the supply of water to Pedra. An American

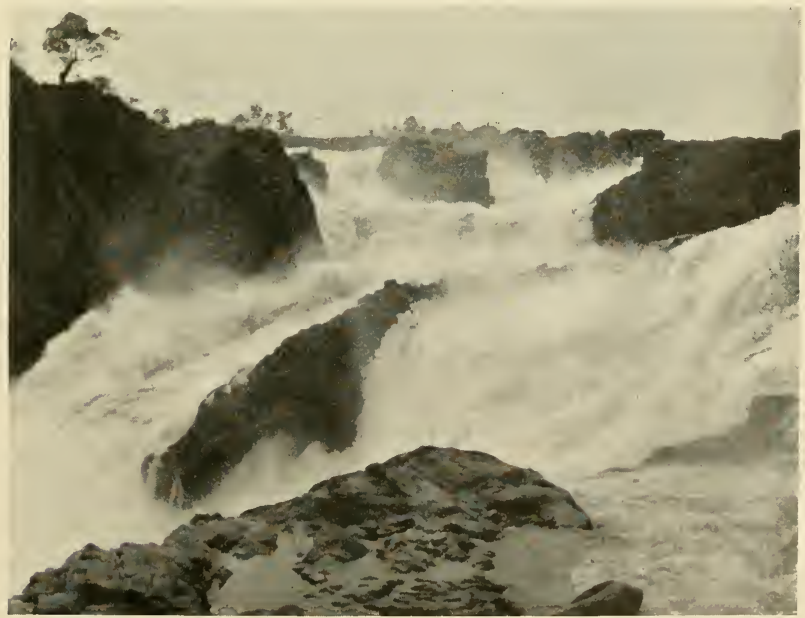

Part view of the Paulo Affonso Falls 
turbine (Chalmers) of 2.500 h.p. has been lying at the Pedra mill since the death of Mr. Delmiro Gouveia, which took place three years ago. The foundations for this new extension have been built and provision has been made for three such additional turbines of 25,000 h.p. Comparatively little additional work for directing the water channel to this new jower station is required. The ultimate scheme of the present owners of this waterfall is to construct altogether a hydroelectric plant of $200,000 \mathrm{~h} . \mathrm{p}$. The site selected is certainly well situated as a building could he constructed between the walls of the two rocks. So far, $2,779,105 \$ 720$ have been spent on the hydroelectric plant, but the last turbine of $2,500 \mathrm{~h} . \mathrm{p}$. Las not yet been erected.

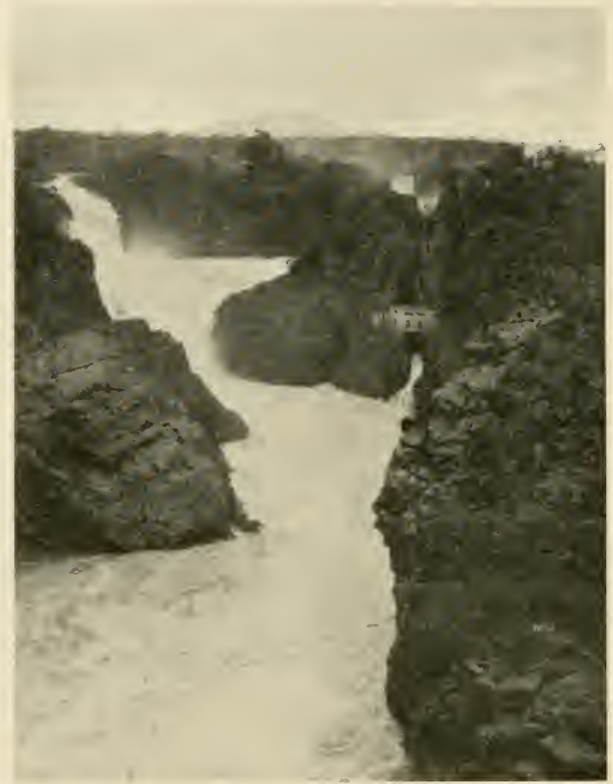

Part View of the Paulo Affonso Falls with Power Station on right side

The sewing thread mill is so far the only industrial undertaking which obtains its electricity from these falls. Of course the village of Pedra is also illuminated with electric light from this plant.

The mill at Pedra has 20 ring frames, each 360 spindles and about 6,000 doubling spindles. All the machinery is from Messrs. Dobson \& Barlow's and was erected between 1913 and 1915. About 6,000 sacks of 64 kilos of Seridô cotton, measuring 35 to $38 \mathrm{~mm}$. in length is being consumed and up to 80 's are spun from it. The cotton used is put in 
sacks of $6 t$ kilos as it has to travel about 300 miles to the coast on mule-back. It is bought in lots of 50 to 200 hales.

The total waste in the course of spinning was 18 per cent. of which the opener aceounted for 6 per cent. The combs take out 20 per cent. but this waste is used for spinning yarns of coarse counts and is sold to the natives for the weaving of hammocks.

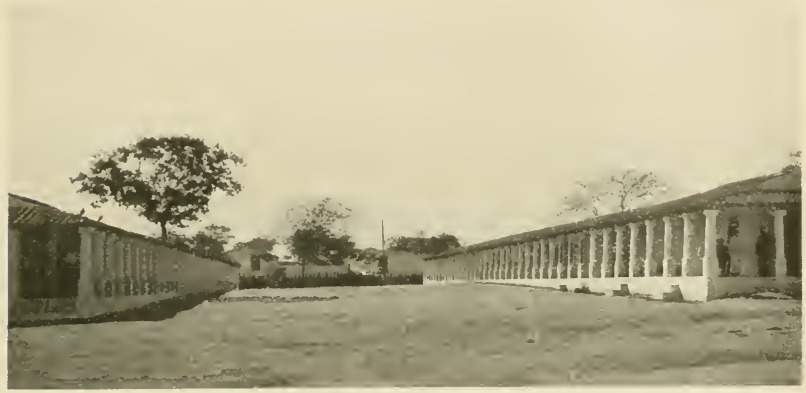

Workmen's Dwellings belonging to the Cotton Thread Mill at Pedra

The operatives live in a specially built village, containing about 500 new houses built in long streets with open squares, surrounding the factory. The houses are roomy and the architeeture and planning of the village are quite modern. There are altogether 4,000 people living at Pedra.

Under normal conditions the sewing thread mill works two shifts and when trade was good even three shifts have been going. At present only 600 operatives are working ten hours a day at an average rate of wages of $1 \$ 800$ for ten hours, but it nust be borne in mind that they live rent free, have electric light and water provided (only lamps have to be paid for).

Strict discipline is kept; the operatives are well behaved, are well-dressed and clean. Whilst going to work they were better dressed than the average European mill hand on a Sunday.

The sewing eotton mill being the only industrial undertaking so far driven by the hydro-electrie plant, it is debited with all the charges of the plant, but nevertheless, during 1919-20 the Company was able to pay a 10 per eent. dividend.

Though the concession states that cotton, cereals and fodder erops should be grown by means of irrigation, I personally doubt whether irrigation is possible as a commereial proposition owing to the undulating nature of the eountry. The Paulo Affonso Falls offer, undoubtedly, an opportunity for future development. The two directors of the Company, Mr. L. Iona and Mr. G. Ferrario, are commereial men, mainly interested in the hide business of Iona \& Co. and would weleome participation of Europeans in the further development of the seheme. 
Cost of Electrictity.-Electricity is very extensively used in Rio de Janeiro and in the whole of the State of São Paulo. Almost every village has electric light and many of the cotton mills are driven by electricity. The "Light and Power Co.," an American-Canadian undertaking, is the supplier of force to many mills in the towns; the price charged varies according to the rate of exchange. As their shareholders are abroad they stipulated wisely in their concession the right of fixing the consumers' price according to the exchange.

The cost of electricity for a mill in São Paulo, which obtains the force from the above company works out as follows:

Tension : 2,080 volts.

Price: Rs. 300 per kilowatt hour, with rebate of 88 per cent., according to consumption, maximum load and English rate of exchange.

July, 1920. Consumption : 525,600 kilowatt-hours, maximum load $2,040 \mathrm{kw}$., English rate of exchange $14 \mathrm{~d} .=1 \$ 000$, rebate 87 per cent.

Rs. 300 less 87 per cent. $=$ Rs. 39 per kilowatt-hour.

Feb., 1921. Consumption : 434,400 kilowatt-hours, maximum load $1,800 \mathrm{kw}$. , English rate of exchange $10 \mathrm{~d} .=1 \$ 000$, rebate 79 per cent.

Rs. 300 less 79 per cent. $=$ Rs. 63 per kilowatt-hour.

Lighting is charged at the same rate. As there is a very abundant supply of water in the south of Brazil and a great many waterfalls many industrial undertakings, especially cotton mills, have been

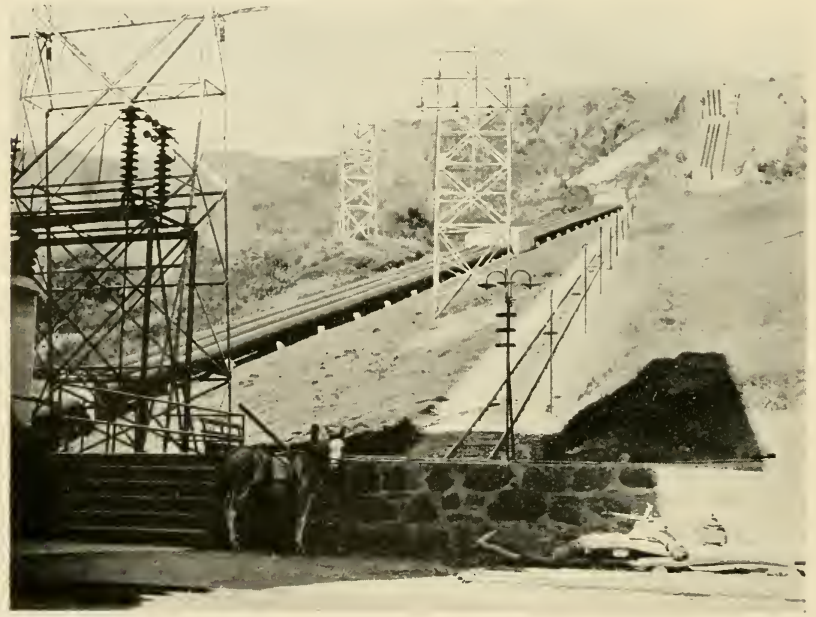

The Hydro-Electric Plant of the Light \& Power Company near Sorocaba, which supplies power to many cotton mills in São Paulo 
established near such falls. The law in Brazil is that the one who owns the land on both sides of a river is also the proprietor of the river. In this way many mills have acquired in the past huge water forces at low prices. One such fall capable of supplying 3,000 h.p. has a hydro-electric plant for 1,700 h.p. costing 300 contos. Light to three towns and power for the cotton spinning and weaving mill are supplied. At another place in the same State 2,000 h.p. were generated, the installation costing also 300 contos. Light is supplied to five towns and power to a mill with $9,400 \mathrm{ring}$ spindles and 480 looms. The largest waterfalls generating electricity which we saw in Brazil are the Pãulo Affonso Falls, mentioned on pages 35-36.

Fuel.--Steam is generally generated by wood fires, but some mills have boilers that can be fired with oil, wood or coal. With the present rate of exchange at considerably below one shilling per milreis it does not pay to import coal from England or U.S.A. Coal of a kind is found in Santa Catharina, in the south of Brazil, but so far it has not given satisfaction. Recently some people talked of having found oil in Brazil, but this is a question of the future. Even with the present low rate of exchange one or two mills were importing oil as fuel for the boilers. But the fuel in general use is wood, tree roots and knotted pieces, which are sold at 8 to $10 \$ 000$ per cubic metre in São Paulo and Rio. In the interior the price is lower, of course the railway freight causing the difference. Brazilians have been very lavish in the use of wood for fuel and it is realised that unless afforestation is more generally adopted, not so many years will elapse before the supply is used up, though at first glance it seems inexhaustible. It must be borne in mind that every household, every locomotive (with the exception when ascending steep gradients), and most of the boiler fires use wood as fuel. São Paulo and also some northern States have for this reason embarked on afforestation, using the rapidly growing eucalyptus tree, which after five years' growth is ready to be cut down for timber. Literally millions of these trees have been planted of late in Brazil and in most cases these plantations have given every satisfaction.

One mill which we visited had a peat deposit in the neighbourhood and used peat and wood for fuel for the boilers.

Taxes.--Besides the land taxes, taxes are payable on every metre of cloth produced in the mills. (So far there is no tax on cloth woven on the hand looms.) The following are the present rates:

Cotton cloth of any width or weight pays per metre :-

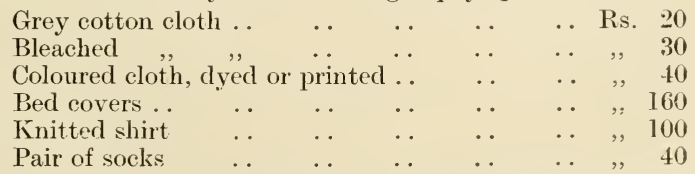

A mill with 1,237 ordinary looms, 224 Northrop looms and 62 Jacquard looms paid last year more than $600,000 \$ 000$ in such taxes.

The form of payment is by means of stamps which have to be fixed to each Invoice.

Every piece of goods must bear the inscription "Brazilian make." 
All textile machinery from abroad pays 15 per cent. IMPORT DUTY ad valorem, 55 per cent. of which is payable at the rate of gold dollars, so that the actual duty works out to 40 to 50 per cent. paper money, ad valorem, according to the rate of exchange.

Method of Sale.-The method of sale of goods is in almost all cases a simple one. There are in Rio many wholesale dry goods stores which are frequently shareholders in the mills. At times a mill will sell its whole production on commission through one of these dry goods houses, paying $8 \%$ commission and $2 \%$ for the Deleredere. In other cases the mill has six to ten dry goods houses as customers, they buying outright. In the case of financially weak cotton mills, the big wholesale dry goods firms act as bankers. It happens at times that goods made in Bahia or Minas are sent to Rio and sold again by the Rio houses to the same States; but generally these goods will be sold on the reference patterns and sent direct from the mill to the customer of the Rio dry goods house.

A number of Rio firms selling national goods used to do exclusively an import business of cotton goods from Europe. This has fallen off enormously as will be seen from the table of imports, and consequently the importing houses have taken up during the last 15 years the sale of national goods. Formerly the buyers (shopkeepers, etc.) from the Interior used to come regularly to Pio to make their purchases, but with increased competition the dry gonds houses have now to send a large number of travellers into the Interior. Business has ceased to come to Rio. consequently the Rio houses had to go after business into the Interior. Some of these travellers are often away a year on their journey and in view of the somewhat unreliable mail service, it is necessary to telegraph orders and practically all the communications. Large remittances from the Interior are frequently sent in paper money by an ordinary native messenger.

The Making-UP and Pattern Roons were generally extremely well managed and situated in very pleasant and light quarters. Special care was taken in the preparation of "reference" patterns. An electric iron was used in several pattern rooms to bring up the finish of the goods.

The mill store-rooms of the larger concerns are a pattern of system : every article entering or leaving is most methodically booked.

Profits.--As to the average profit of the cotton industry i have been told on good authority that 1:2 per cent. is generally divided. Many mills are making much bigger profits; they keep enlarging their concerns out of profit, still paying 10 to 12 per cent. dividend. A good deal is said by liio and São Paulo people of the graft and thefts committed in many cotton mills : it is maintained that responsible heads of departments will give orders only if they receive secret commission. I am not able to say whether this statement is correct or not, but I am inclined to think that it is one of the many exaggerations told by Europeans resident in Brazil because they have not been able to obtain certain orders for machinery or mill furniture. One English mill manager told us, however, that his concern did not pay prior to his arrival, principally because so much money and goods were stolen. 
Ten or twelve per cent. profit in a country where money pavs one per cent. interest per month would not be looked upon as a satisfactory return on the outlay. A cotton mill under efficient management is a good investment. The demand for national goods is greater than can be supplied. It is recognised that most of the Brazilian cotton mills use by far too good a quality of cotton for the low counts they spin, and in this direction alone a good saving conld be obtained. The mills have made such handsome profits that some do not consider. it worth their while to study economy.

Even during the recent crisis under which Brazil suffered severely there was no lack of orders. Some mills stopped for one or two days a week principally beeause they did not know whether their customers were still financially sound. I was told repeatedly hy mill men that one did not know who was financially sound, as over-trading is a general habit amongst Brazilians, and in times of a slump in prices such concerns suffer severely. Brazil is a country with marvellous forces of recovery and towards the end of August, 19:21, it was thought that the crisis, as far as Brazil was concerned, had turned.

Organisations. - There are in Brazil three Master Cotton Spimners' and Manufacturers' Associations, viz. :-

1. Centro Industrial de Fiação e Tecelagem, Rua Candelaria, 61. $1^{\circ}$ andar, Rio de Janeiro.

2. Centro dos Industriaes de Fiação e Tecelagem, Rua Direita 27, sobrado, São Paulo.

3. Centro Industrial do Algodão no Bahia, Bahia.

Most of the mills in the States where these organisations are situated are affiliated to them. Their aim and objects are to protect the common interests of the industry.

Meetings were called by each of these organisations in order to enable me to address the nembers on the work of the International Cotton Federation. Resolutions were adopted by these organisations in favour of affiliation with the International Cotton Federation.

Besides these three associations there is in existence in Rio de Janeiro a federation known as "Centro Industrial do Brazil." Up to recently the cotton mills which now constitute the above Rio Association were members of this Federation. Some mills in the north. Pernambuco, Ceará and one mill in São Paulo are members of the Centro Industrial only. The "Centro Industrial do Brazil" is a federation of Brazilian industries of all kinds: it takes a special interest in political questions as affecting industry.

There is a TRADE UNION in existence in Rio de .Taneiro amongst the cotton mill workers, towards which the operatives pay I $\$ 000$ per month contribution: it is styled: "União dos Operarios das Fabricas de Tecidos," but the Masters' organisations do not recognise the union. Every now and then the Spanish element amongst the cotton operatives tries to create dissatisfaction. The Italian workpeople in São Paulo are docile and very well liked; in some milis as many as 60 per cent. are Italians. Many Portuguese work in the mills and make good operatives. 
In some large mills the operatives have their own sick clubs, the monthly subscription in one case was $2 \$ 000$ and the benefit $70 \$ 000$ per month.

Welfare Work. - Every mill of importance in Brazil undertakes a good deal of welfare work, and as labour is plentiful one cannot but admire the spirit in which it is undertaken. There is no mercenary purpose underlying this work- of this I am certain. There is a club, school, football field, tennis ground, etc., attached to almost every mill. A first-aid room is to be found and in many establishments it is the custom for a qualified doctor to be in attendance at the mill during one hour each day. Workmen's dwellings are provided at a low cost.

The most elaborate system of Welfare Work* which has come to my notice is that carried out by Dr. Jorge Street of São Paulo ; it excels by far any of the welfare institutions I have seen in the U.S.A. Mr. Street told me that he was considered a "Bolshevilk" by his confrères, but he maintains that all he does for the benefit of his workpeople is not of a charitable nature, on the contrary he insists that it is the share due to them under his form of co-partnership. Rather than give his workpeople during good years higher wages which would be frittered away in useless things, he lets them have the corresponding profit by improved methods of living.

The following are the main features of Mr. Street's social work for his operatives:

The model village where his cotton mill operatives live is a suburb of itself, built entirely on modern lines. The latest additions have little front gardens, every house has electric light and water. The rent paid is $3 \frac{1}{2}$ per cent. on the cost of construction.

There is a "crèche " containing 62 cots, each one having a linen and a crockery locker. Each piece of linen is carefully numbered to correspond with the number of the cot. The babies are left there when 3 weeks old and are cared for by qualified nurses. Each room in the erèche has a pasteurized store of milk. Bedling, floors, etc., are spotlessly clean. Special rooms are provided for nursing mothers. There is no reduction of wages for the time the mothers spend in feeding their babies. In this crèche the children remain until they reach the age of four. From that time until they are seven years they attend the "Kindergarten," which consists of a number of playrooms and gravel playgrounds, properly roofed. Cleanliness is one of the principal items taught to these young children. There is an ample supply of wash basins with hot and cold water. Each child has a handkerchief attached to his clothing. There are a set of well ventilated classrooms, the children sit at low tables, of which the tops are divirled into squares for making designs for weaving. The children learn the use of colours with blocks which they fit in the squares and accustom themselves from early age to designs of woven patterns. All kinds of ordinary kindergarten lessons are taught. Besides the classrooms there are bedrooms provided, for the younger children must have two hours sleep during the day.

* In view of the discussion at the last Intemational Cotton Congress, I gjve this information in some detail. 
There is also a separate dining room, each child having its own spoon, etc. The dining tables were scattered with insect powder to keep flies away.

Special clothing is provided, every child when coming to the institute must have a complete change.

A staff of 20 qualified kindergarten teachers is engaged.

After the completion of seven years the children pass into the proper school. The hours are from 8 to 11 and 1 to 4 . The attendance here is 550 scholars for whom there are 20 classrooms and 14 teachers.

This institution of the "Maria Zelia" village (so called after a daughter of Mr. Street) is also for the benefit of the operatives working at other mills of Mr. Street and living at a distance. Motor chars-àbanes bring these children in the morning and take them home in the evening. 4,700 operatives are working for Mr. Street in one or the other milis.

Mrs. Street is in attendance every morning from 8 o'clock and personally superintends crèche, kindergarten and school.

There are five doctors and two pharmaccutical stores in the village ; also a big store, where almost anything can be bought at cost price. Last year's turnover at the store was 1,800 contos and the loss on the transactions amounted to 3 contos.

A fine church has been built and close by is a huge theatre with seating accommodation for 1,200 people. One large room is to be used for dancing under the supervision of a dancing master. There is also a professor of music. Shower baths and rooms for games are provided ; football and tennis grounds are also laid out.

Wine and beer may be had in the village restaurants, but no strong alcoholic drinks.

The village has its own force of 200 Federal soldiers, whose equipment is provided by the firm. In this way the young men, due for military service, amongst the villagers (for conscription is in force in Brazil), may do their service on the spot and be close to family influence.

By 9 p.m. every resident of the village has to be within the boundaries.

The workpeople look happy, they are clean and seem to have self respect. 


\section{IMPORTS OF COTTON PIECE GOODS INTO BRAZIL*}

The following tables show the decreases which have taken place in the importation into Brazil of manufactured cotton goods:

PIECE GOODS BLEACHED

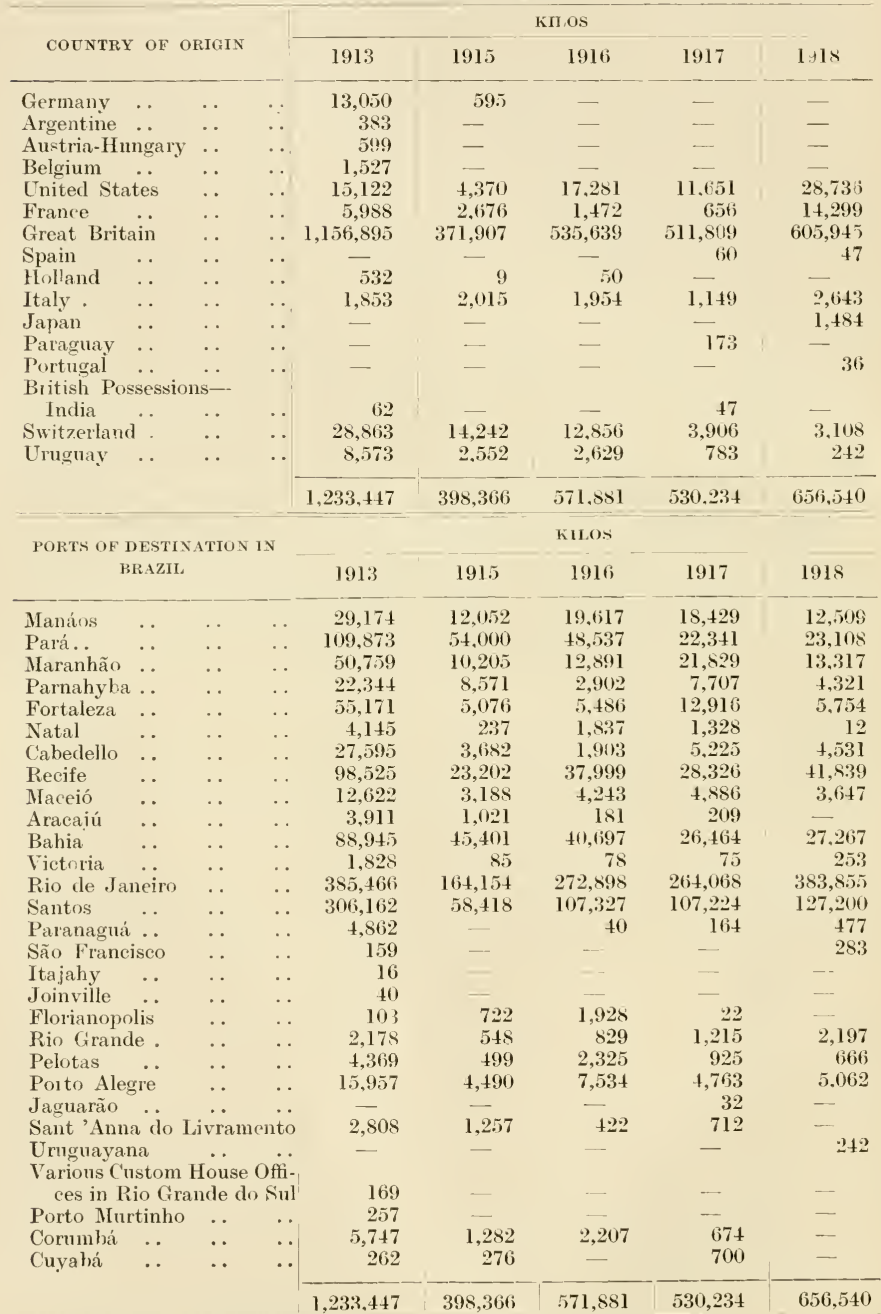

* I regret I could not obtain more up-to date tables. 
PIECE GOODS UNBLEACHED

\begin{tabular}{|c|c|c|c|c|c|c|c|}
\hline \multirow{2}{*}{\multicolumn{3}{|c|}{ COUNTRY OF ORIGIN }} & \multicolumn{5}{|c|}{ KILOS } \\
\hline & & & 1913 & 1915 & 1916 & 1917 & 1918 \\
\hline Germany . & .. & $\ldots$ & 1,462 & 91 & - & - & $\ldots$ \\
\hline United State & .. & .. & 4,707 & 522 & 746 & 542 & 5,006 \\
\hline France & .. & . & 2,119 & - & 394 & - & 1,038 \\
\hline Great Britair & $\ldots$ & .. & 220,671 & 30,422 & 106,029 & 13,138 & 18,838 \\
\hline Spain & . & .. & - & 12 & - & 4,028 & - \\
\hline Holland & .. & .. & 5,862 & 123 & - & - & - \\
\hline Italy . & .. & .. & 609 & - & - & 70 & - \\
\hline Paraguay & .. & .. & - & - & - & - & - \\
\hline Portugal . & .. & .. & 559 & 117 & - & 144 & -- \\
\hline Switzerland & . & .. & 1,145 & 2,438 & 345 & - & - \\
\hline \multirow[t]{2}{*}{ Uruguay . } & . & . & 1,716 & - & 311 & - & - \\
\hline & & & 238,850 & 33,725 & 167,825 & 17,922 & $24,8 s 2$ \\
\hline
\end{tabular}

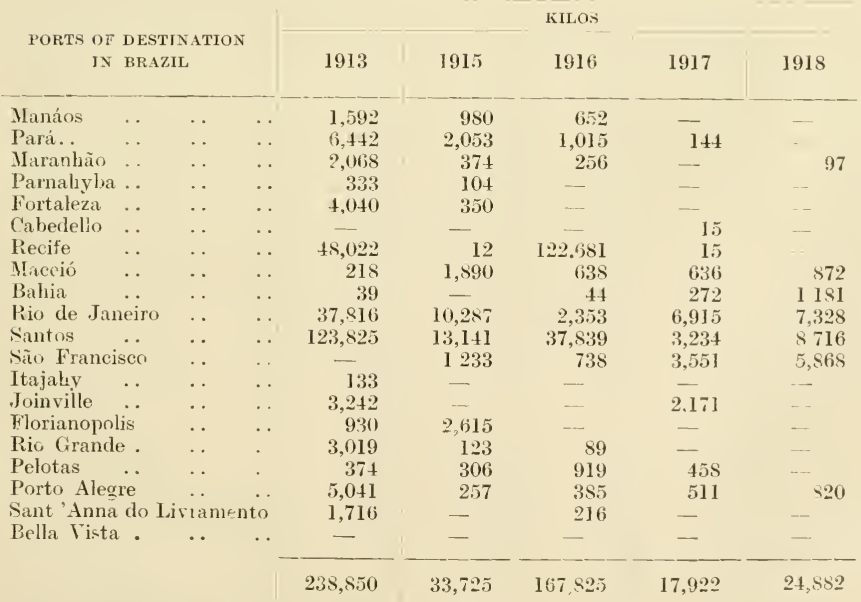


PIECE GOODS PRINTED

\begin{tabular}{|c|c|c|c|c|c|c|c|c|}
\hline \multirow{2}{*}{\multicolumn{4}{|c|}{ COUNTRY OF ORIGIN }} & \multicolumn{5}{|c|}{ KILOS } \\
\hline & & & & \multirow{2}{*}{$\frac{1913}{17,075}$} & \multirow{2}{*}{$\begin{array}{r}1915 \\
135\end{array}$} & \multirow{2}{*}{$\frac{1916}{157}$} & \multirow{2}{*}{1917} & 1918 \\
\hline Germany & $\ldots$ & $\ldots$ & & & & & & -. \\
\hline Austria-Hu & ingary & . & .. & 7,197 & - & - & - & - \\
\hline Belgium & .. & .. & .. & 3,625 & - & - & - & - \\
\hline U.S.A. & .. & .. & . & 1,627 & 705 & $2,24 \mathrm{I}$ & 2,680 & 29,360 \\
\hline France & .. & .. & .. & 6,207 & 158 & 12 & 657 & 964 \\
\hline Great Brit & ain & .. & .. & 299,202 & 55,366 & 131,033 & 127,596 & 162,910 \\
\hline Spain & .. & .. & .. & 1,265 & - & 1,712 & - & - \\
\hline Holland & .. & .. & .. & 627 & - & - & - & - \\
\hline Italy & .. & .. & . & 6,000 & $7 \pm 6$ & -- & - & 1,355 \\
\hline Japan & . & .. & .. & 6 & - & - & - & - \\
\hline Paraguay & .. & .. & .. & - & - & - & 195 & - \\
\hline Portugal & . & . & & 9 & 174 & 一 & - & - \\
\hline British Po & ssession & s- & & 186 & - & $\ldots$ & $\ldots$ & - \\
\hline Switzerlanc & d. & .. & .. & 1,727 & - & - & 116 & 8 \\
\hline \multirow[t]{2}{*}{ Uruguay } & .. & .. & . & 7,856 & 1,657 & 1,118 & 331 & - \\
\hline & & & & 352,609 & 58,941 & 136,273 & 131,575 & 194,597 \\
\hline
\end{tabular}

\begin{tabular}{|c|c|c|c|c|c|c|c|c|}
\hline \multirow{2}{*}{\multicolumn{4}{|c|}{$\begin{array}{l}\text { PORTS aF DESTINATION } \\
\text { IN BRAZIL }\end{array}$}} & \multicolumn{5}{|c|}{ KILOS } \\
\hline & & & & 1913 & 1915 & 1916 & 1917 & 1918 \\
\hline Porto Velh & & .. & $\ldots$ & 196 & 252 & - & - & - \\
\hline Manáos & . & .. & .. & 26,196 & 15,551 & 22,545 & 6,177 & 5,668 \\
\hline Pará.. &.. & .. & .. & 36,712 & 8,650 & 16.063 & 6,637 & 3,620 \\
\hline Maranhão & .. & .. & .. & 27,368 & 1,328 & 1,499 & 4,838 & 2,585 \\
\hline Parnahyba & .. & .. & .. & 6,378 & 494 & 515 & 3,518 & 1,211 \\
\hline Fortaleza & .. & .. & .. & 10,783 & 100 & 210 & 1,045 & 2,165 \\
\hline Natal & .. & .. & .. & 110 & - & 35 & - & - \\
\hline Cabedello & .. & .. & .. & 8,599 & 1,025 & 111 & 1,557 & 784 \\
\hline Recife & .. & .. & .. & 37,373 & 2,828 & 6,873 & 6,564 & 22,166 \\
\hline Mlareió & .. & .. & $\because$. & 7,463 & 45 & 202 & 2,064 & 3,525 \\
\hline Aracajú & .. & .. & .. & 5,511 & - & - & 138 & - \\
\hline Bahia & .. & .. & .. & 34,384 & 5,477 & 9,608 & 7,871 & 4,601 \\
\hline Victoria & .. & .. & .. & 321 & - & - & - & - \\
\hline Rio de Jar & neiro & .. & .. & 59,480 & 13,782 & 50,403 & $\tilde{5} 3,803$ & 105,923 \\
\hline Santos & .. & .. & .. & 72,479 & 6,385 & 24,127 & 32,889 & 41,140 \\
\hline Paranaguá & .. & .. & $\therefore$ & 4,937 & 35 & - & 44 & - \\
\hline São Franci & isco & .. & .. & 175 & - & - & - & - \\
\hline Joinville & $\ldots$ & .. & .. & 115 & - & - & - & - \\
\hline Florianopo & & .. & .. & 78 & 418 & - & 260 & 24 \\
\hline Rio Grand & & .. & .. & 3,191 & 120 & - & 243 & 96 \\
\hline Pelotas & .. & .. & .. & 760 & 339 & 1,307 & 155 & 42 \\
\hline Porto Aleg & & .. & .. & 2,430 & 45.5 & 1,289 & 1,927 & 939 \\
\hline Sant'Anna & do $\mathrm{Li}$ & ram & & 4,492 & 285 & 677 & 331 & - \\
\hline Uruguayan & & $\ldots$ & .. & 45 & - & - & - & - \\
\hline Porto Mur & tinho & .. & .. & 250 & - & - & - & - \\
\hline Corumbá & .. & .. & .. & 2,306 & 1,372 & 441 & 780 & 108 \\
\hline Cuyabá & .. & . & .. & 477 & - & - & 734 & - \\
\hline
\end{tabular}


COTTON PIECE GOODS, DYEI

\begin{tabular}{|c|c|c|c|c|c|c|c|c|}
\hline \multirow{2}{*}{\multicolumn{3}{|c|}{ COUNTRY OF ORIGIN }} & & \multicolumn{5}{|c|}{ KILOS } \\
\hline & & & & 1913 & 1915 & 1916 & 1917 & 1918 \\
\hline Germany & . & .. & .. & 46,814 & 6,170 & -- & - & - \\
\hline Austria-Hus & ngary & .. & .. & 6,025 & - & - & - & - \\
\hline Belgium & . & .. & .. & 52,390 & 525 & - & - & - \\
\hline Denmark & .. & .. & .. & - & 1,708 & - & - & - \\
\hline U.S.A. & . & .. & .. & 42,060 & 8,830 & 17,360 & 41,593 & 58,612 \\
\hline France & .. & .. & .. & 39,989 & 4,145 & 987 & 2,840 & 28,468 \\
\hline Great Brita & ain & .. & . & $1,554,126$ & 563,586 & $1,090,823$ & $1,363,622$ & $1,390,347$ \\
\hline Spain & .. & .. & .. & 517 & 8.58 & 322 & - & 232 \\
\hline Holland & .. & .. & .. & 2,805 & 551 & - & - & - \\
\hline Italy & .. & .. & .. & 45,028 & 7,069 & 10,616 & 40,052 & 40,644 \\
\hline Paraguay & .. & .. & .. & - & - & - & 1 & 1 \\
\hline Portugal & . & .. & .. & 165 & 41 & 53 & - & 18 \\
\hline Sweden & .. & .. & .. & - & 2,020 & - & - & - \\
\hline Switzerland & 1 . & .. & . & 7,000 & 4,420 & 6,750 & 840 & 2,125 \\
\hline Uruguay & .. & .. & . & 11,195 & 3.306 & 3,427 & 1,456 & 1,317 \\
\hline Tota & & $\cdots$ & .. & $1,808,114$ & 603,229 & $1,130.338$ & $1.450,404$ & $1,521,764$ \\
\hline
\end{tabular}

\begin{tabular}{|c|c|c|c|c|c|c|c|c|}
\hline \multirow{2}{*}{\multicolumn{4}{|c|}{$\begin{array}{l}\text { PORTS OF DESTINATION } \\
\text { IN BRAZIL }\end{array}$}} & \multicolumn{4}{|c|}{ KILOS } & \multirow[b]{2}{*}{1918} \\
\hline & & & & 1913 & 1915 & 1916 & 1917 & \\
\hline Manáos & .. & .. & $\ldots$ & 23,116 & 10,836 & 25,583 & 10.959 & 10,364 \\
\hline Pará.. & .. & .. & . & 139,401 & 74,803 & 112,266 & 48,052 & 26,837 \\
\hline Maranbão & .. & .. & .. & 42,579 & 8,714 & 14,763 & 19,070 & 17,078 \\
\hline Parnahyba & $\ldots$ & $\cdots$ & $\cdots$ & 11,864 & 3,659 & 5,145 & 7,878 & 5,828 \\
\hline Fortaleza & .. & $\ldots$ & .. & 61,783 & 6,203 & 7,200 & 24,490 & 13,376 \\
\hline Natal & .. & $\cdots$ & .. & 7,188 & 3,477 & 2,527 & 1,910 & 125 \\
\hline Cabedello & .. & .. & .. & 42,479 & 11,898 & 11,766 & 12,847 & 7,346 \\
\hline Recife & .. & $\cdots$ & $\cdots$ & 250,369 & 70,188 & 97,364 & 103,359 & 100,172 \\
\hline Maceió & .. & .. & .. & 64,331 & 20,061 & 20,256 & 19,784 & 8,679 \\
\hline Aracajú & .. & . & . & 3,265 & 604 & 297 & 1,557 & - \\
\hline Bahia. & .. & .. & . & 117,902 & 93,285 & 79,642 & 75,808 & 60,119 \\
\hline Victoria & . & . & $\cdots$ & 1,184 & - & 334 & 1,233 & J,313 \\
\hline Rio de Jan & eiro & .. & .. & 672,845 & 206,566 & 529,697 & 811,969 & 961,633 \\
\hline Santos & $\ldots$ & .. & .. & 258,301 & 67,835 & 174,796 & 268,700 & 290,914 \\
\hline Paranaguá & & $\cdots$ & $\ldots$ & 8,819 & 24 & 327 & 1.640 & 648 \\
\hline São Francis & seo & .. & .. & 563 & 22 & 213 & - & - \\
\hline Itajahy & .. & .. & .. & 33 & - & - & - & - \\
\hline Joinville & & .. & .. & 251 & - & - & - & - \\
\hline Florianopol & & .. & . & 2,439 & 2,266 & 2,784 & 1,556 & 279 \\
\hline Rio Grande & & .. & .. & 6,193 & 1,100 & 4,252 & 1,299 & 491 \\
\hline Pelotas & & & .. & 6,020 & 1,831 & 2,870 & 3,029 & 1,551 \\
\hline Porto Aleg & & .. & .. & 76,074 & 16,770 & 34,813 & 33,520 & 13,414 \\
\hline Sant'Anna & do & Livramen & nto & 10,294 & 3,033 & 3,197 & 1,456 & 1,596 \\
\hline Uruguayan & & . & . & 70 & - & 179 & - & - \\
\hline Various $\mathrm{Cu}$ & & Houses & in & & & & & \\
\hline Rio Gran & nde d & o Sul & .. & - & - & 16 & - & - \\
\hline Porto Murt & tinho & .. & .. & 439 & - & - & - & - \\
\hline Corumbá & .. & $\ldots$ & $\cdots$ & 312 & 54 & 51 & 287 & - \\
\hline Bella Vista & & .. & . & - & - & - & 1 & 1 \\
\hline
\end{tabular}




\section{COTTON PIECE GOODS, NOT DETAILED}

\begin{tabular}{|c|c|c|c|c|c|c|c|c|}
\hline \multirow{2}{*}{\multicolumn{4}{|c|}{ COUNTRY OF ORIGIN }} & \multicolumn{5}{|c|}{ KILOS } \\
\hline & & & & 1913 & 1915 & 1916 & 1917 & 1918 \\
\hline Germany & $\ldots$ & $\ldots$ & .. & 935,901 & 23,815 & 255 & - & - \\
\hline Argentina & .. & .. & . & 2,251 & 3,383 & 2,592 & 3,188 & 5,102 \\
\hline Austria $\mathrm{H}_{1}$ & ungary & .. & .. & 122,887 & 3,106 & - & $\ldots$ & - \\
\hline Belgium & .. & .. & .. & 386,985 & 2,351 & - & - & - \\
\hline Denmark & .. & .. & .. & - & 265 & - & - & -. \\
\hline U.S.A. & .. & .. & .. & 98,791 & 69,727 & 253,368 & 502,356 & 730,211 \\
\hline France & .. & .. & .. & 253,028 & 63,556 & 59,577 & 38,151 & 119,384 \\
\hline Great Brit & ain & . & .. & $3,755,724$ & $1,456,827$ & $2,416,210$ & $1,394,851$ & ],350,928 \\
\hline Spain & .. & $\ldots$ & . & 4,421 & 900 & 3,202 & 5,937 & 5,180 \\
\hline Holland & .. & $\ldots$ & .. & 33,983 & 11,325 & 3,164 & 1,852 & 1.980 \\
\hline Italy & .. & .. & .. & 468,329 & $\$ 2,915$ & 92,048 & 38,432 & 38,380 \\
\hline Japan & .. & $\ldots$ & .. & 163 & 628 & 192 & $\tilde{563}$ & 4,045 \\
\hline Norway & .. & .. & .. & - & - & 115 & 4,577 & - \\
\hline Paraguay & .. & .. & .. & - & 5,747 & 1,317 & 3,598 & - \\
\hline Portugal & .. & .. & .. & 1,092 & 592 & 3,732 & 405 & 804 \\
\hline \multicolumn{9}{|c|}{ British Possessions- } \\
\hline Canada & .. & .. & .. & - & 1,056 & 6,001 & $1, \$ 17$ & 1,791 \\
\hline India & .. & . & .. & - & - & 34 & $\ldots$ & - \\
\hline Russia & . & .. & .. & 2,822 & -- & - & - & - \\
\hline Sweden & & .. & .. & 75 & 2,412 & 125 & - & - \\
\hline Switzerlan & & .. & .. & 91,486 & 99.600 & 101,757 & 27,242 & 18,622 \\
\hline Uruguay & & $\ldots$ & .. & 55,181 & 13.688 & 12,294 & 6,435 & 25,553 \\
\hline Outras Ori & igens & $\ldots$ & .. & 119 & - & - & - & - \\
\hline Tot & & . & .. & $6,213.168$ & $1,841, \$ 93$ & $2,95 \times .953$ & $2,029,434$ & $2,301,981$ \\
\hline \multirow{2}{*}{\multicolumn{4}{|c|}{$\begin{array}{c}\text { PORTS OF DESTINATION } \\
\text { IN BRAZIL }\end{array}$}} & \multicolumn{5}{|c|}{ Kா̆оs } \\
\hline & & & & 1913 & 1915 & 1916 & 1917 & 1918 \\
\hline \multicolumn{3}{|c|}{ Porto Velho } & .. & 1,668 & & - & 二 & - \\
\hline Manáos & $\ldots$ & .. & .. & 51,252 & 27,196 & 22.170 & 10,035 & 9,398 \\
\hline Pará.. & .. & $\ldots$ & .. & 136,155 & 71,033 & 72,055 & $4 ?, 659$ & 22.965 \\
\hline Mlaranhão & .. & .. & .. & 37,601 & 11,051 & 11,676 & 23,792 & 15,635 \\
\hline Parnahyba & . . & .. & .. & 3,290 & 1,393 & 1,531 & 2,025 & 464 \\
\hline Fortaleza & .. & . & .. & 42,535 & $6,6 \pm 8$ & 11,541 & 14,493 & 24,809 \\
\hline Natal & .. & .. & .. & 7,550 & 994 & - & - & 78 \\
\hline Cahedello & .. & $\ldots$ & .. & 33,206 & 2.670 & 5,242 & 4,124 & 4,466 \\
\hline Recife & .. & $\ldots$ & .. & $3 \tilde{4} 4,336$ & $11 \leqslant, 405$ & 143,062 & 153,642 & 187,914 \\
\hline Maceió & .. & .. & .. & 61,178 & 8,636 & 15,819 & 10,923 & 7,733 \\
\hline Penedo & .. & .. & .. & - & - & - & - & 620 \\
\hline Aracajú & .. & . & .. & 10,103 & 1.875 & 442 & 177 & - \\
\hline Bahia & .. & .. & .. & 216,838 & T×,989 & 183,790 & 80,794 & 73,494 \\
\hline Victoria & & .. & .. & 3,329 & 562 & 2,262 & 273 & 280 \\
\hline Rio de Ja & neiro & $\ldots$ & .. & $2,464,311$ & 928,728 & $1,782,859$ & $1,296,161$ & $1,510,143$ \\
\hline Santos & .. & . & .. & 667,167 & 93,$886 ;$ & 521,138 & 282,276 & 356,128 \\
\hline Paranaguá & .. & .. & .. & 52,126 & 1,392 & 2,378 & 393 & - \\
\hline Antonina & .. & . & .. & - & 10 & - & - & 4 \\
\hline Fóz do Ig & uassú & .. & . & 59 & - & $13 \mathrm{~s}$ & - & $66 \mathrm{~s}$ \\
\hline \multicolumn{2}{|c|}{ São Francisco } & $\ldots$ & .. & $14.16 \mathrm{~K}$ & 1,073 & 3,230 & 496 & 549 \\
\hline Itajahy & & .. & . & 1,645 & - & 157 & 527 & 151 \\
\hline Joinvilie & & $\ldots$ & .. & 22,490 & 4,188 & 5,618 & 2,075 & - \\
\hline Florianopo & & .. & .. & 90,554 & 8.719 & 5,391 & $1, \$ 80$ & 839 \\
\hline Rio Grand & & .. & . & 185,627 & $46,37 \mathrm{~s}$ & 42,867 & 38,896 & 58,394 \\
\hline Pelotas & & .. & .. & 31,519 & 5,314 & 10.572 & 6,739 & 3,208 \\
\hline Porto Ales & & .. & .. & 670,516 & 106,141 & 104,496 & 48,845 & 20,502 \\
\hline \multicolumn{4}{|c|}{ Sant'Anna do Livramento } & 13,159 & 1.971 & 1,130 & 1,733 & 967 \\
\hline Quarahy & .. & .. & . & - & 175 & - & - & - \\
\hline Urugnayan & & .. & .. & $9,2.51$ & 4,155 & 2,375 & 1,480 & 1,541 \\
\hline \multirow{2}{*}{\multicolumn{9}{|c|}{ Tarious Custom Hous }} \\
\hline & & & & & & & & \\
\hline Rio Gral & nde do & $S u l$ & . & 149 & Dace & 474 & 51 & 一 \\
\hline Porto Mnr & tinho & . & . & 2,463 & $366 \mathrm{j}$ & 327 & - & - \\
\hline Corumbá & .. & . & . & 26,216 & $9,91 \%$ & 6,243 & 4,938 & 663 \\
\hline Cuyabá & .. & .. & & 2.707 & - & - & - & - \\
\hline Bella Vist & a. & .. & .. & - & - & _- & 2 & - \\
\hline
\end{tabular}




\section{IMPORTS OF COTTON YARN.}

\begin{tabular}{|c|c|c|c|c|c|c|c|}
\hline \multicolumn{2}{|c|}{ YEARS } & \multirow[b]{2}{*}{.. } & \multirow[b]{2}{*}{.. } & \multirow[b]{2}{*}{.. } & \multicolumn{3}{|c|}{$\begin{array}{l}\text { QUANTITIES } \\
\text { IN KILOS }\end{array}$} \\
\hline 1908 & .. & & & & .. & .. & $2,483,000$ \\
\hline 1909 & . & .. & .. & .. & .. & .. & $2,489,000$ \\
\hline 1910 & . & . & .. & .. & .. & .. & $3,261,018$ \\
\hline 1911 & . & .. & .. & .. & .. & .. & $3,372,000$ \\
\hline 1912 & .. & .. & .. & .. & .. & .. & $3,900,000$ \\
\hline 1913 & .. & .. & .. & . & .. & .. & $3,500,942$ \\
\hline 1914 & .. & .. & .. & .. & . & .. & $2,108,375$ \\
\hline 1915 & .. & .. & .. & .. & . & .. & $2,015,115$ \\
\hline 1916 & .. & .. & .. & . & .. & . & 962,508 \\
\hline 1917 & . & .. & .. & . & .. & .. & 607,505 \\
\hline 1918 & . & . & .. & . & . & . & $1,316,156$ \\
\hline 1919 & .. & .. & .. & . & . & . & 770,806 \\
\hline 1920 & .. & .. & .. & .. & .. & . & 935,810 \\
\hline
\end{tabular}

IMPORTATION OF SEWING THREAD.

\begin{tabular}{|c|c|c|c|c|c|c|c|}
\hline YEARS & & & & & & & $\begin{array}{l}\text { QUANTITIES } \\
\text { IN KILOS }\end{array}$ \\
\hline 1913 & $\cdots$ & . & .. & & $\cdots$ & . & $1,350,359$ \\
\hline 1915 & .. & .. & .. & .. & .. & .. & 851,389 \\
\hline 1916 & .. & .. & .. & .. & .. & .. & 690,720 \\
\hline 1917 & .. & .. & .. & . & .. & .. & 580,454 \\
\hline 1918 & .. & .. & .. & .. & .. & .. & 821,622 \\
\hline
\end{tabular}

SUMMARY OF TOTAL COTTON PIECE GOODS IMPORTED INTO BRAZIL

\begin{tabular}{|c|c|c|c|c|c|c|c|}
\hline \multirow{2}{*}{\multicolumn{3}{|c|}{ COUNTRY OF ORIGIN }} & \multicolumn{5}{|c|}{ KILOS } \\
\hline & & & 1916 & 1917 & 1918 & 1919 & 1920 \\
\hline Germany & $\ldots$ & ... & 412 & - & - & 2,123 & 30,542 \\
\hline Argentina & ... & $\ldots$ & 2,592 & 3,188 & 5,102 & 19,139 & 7,464 \\
\hline Belgium & $\ldots$ & $\ldots$ & - & - & - & 628 & 42,471 \\
\hline U.S.A. & $\cdots$ & $\ldots$ & 290,996 & 558,822 & 851,925 & $1,146,741$ & 674,731 \\
\hline France... & $\cdots$ & $\ldots$ & 62,442 & 42,304 & 164,153 & 108,471 & 186,554 \\
\hline Great Britain & & $\ldots$ & $4,339,734$ & ,411,046 & $3,528,968$ & $2,330,043$ & $3,624,704$ \\
\hline Spain ... & & $\ldots$ & 5,236 & 10,025 & 5,459 & 7,103 & 3,165 \\
\hline Italy $\ldots$ & $\ldots$ & $\ldots$ & 104,618 & 79,70 & 83,0 & 41,581 & 168,288 \\
\hline Japan ... & $\ldots$ & $\ldots$ & 192 & 563 & 5,529 & 22,369 & 3,345 \\
\hline Switzerland & $\ldots$ & $\ldots$ & 124,708 & 32,104 & 23,8 & 11,583 & 116,908 \\
\hline Uruguay & $\ldots$ & $\ldots$ & 19,779 & 9,005 & 27,112 & 31,160 & 4,460 \\
\hline Sundries & $\cdots$ & ... & 14,591 & 12,809 & 4,630 & 2,532 & 4,756 \\
\hline \multicolumn{2}{|c|}{ Total kilos } & ... & $4,965,300$ & $4,159,569$ & $4,699,763$ & $3,723,473$ & $4,867,388$ \\
\hline \multirow{2}{*}{\multicolumn{3}{|c|}{$\begin{array}{l}\text { PORTS OF DESTINA- } \\
\text { TION }\end{array}$}} & \multicolumn{5}{|c|}{ KILOS } \\
\hline & & & 1916 & 1917 & 1918 & 1919 & 1920 \\
\hline Manáos & $\cdots$ & $\ldots$ & 90,567 & 45,600 & 37,939 & 15,173 & 23,360 \\
\hline Pará $\ldots$ & ... & $\ldots$ & 249,936 & 119,933 & 76,530 & 51,519 & 89,361 \\
\hline Maranhão & $\ldots$ & $\ldots$ & 41,085 & & 48,712 & 8,481 & 21,240 \\
\hline Fortaleza & $\ldots$ & $\cdots$ & 24,437 & 52,944 & 46.104 & 15,471 & 16,010 \\
\hline Recife & $\cdots$ & $\cdots$ & 407,979 & 291,906 & 352,091 & 221,226 & 288,368 \\
\hline Maceió... & $\ldots$ & $\ldots$ & 41,158 & 38,293 & 24,456 & 15,015 & 23687 \\
\hline Bahia ... & $\ldots$ & $\ldots$ & 313,781 & 191,209 & 166,652 & 133,609 & 168,258 \\
\hline Rio de Janeir & & $\ldots$ & $2,638,210$ & $2,432,916$ & $2,968,882$ & $2,145,399$ & 2,865,999 \\
\hline Santos & & $\cdots$ & 865,227 & 694,323 & 824,098 & 766,305 & $1,165,678$ \\
\hline Florianopolis & & $\ldots$ & 10,471 & 3,718 & 1,139 & 12,178 & 23,186 \\
\hline Pio Grande & $\ldots$ & $\ldots$ & 48.037 & 41,653 & 61,178 & 260,659 & 47,890 \\
\hline Pelotas & $\ldots$ & $\ldots$ & 17,993 & 11,306 & 5,467 & 5,403 & 7,043 \\
\hline Porto Alegre & ... & $\ldots$ & 148,517 & 89,566 & 40,737 & 42,588 & 81,218 \\
\hline Diversos & $\ldots$ & $\ldots$ & 67,902 & 76,773 & 45,778 & 30,447 & 43,090 \\
\hline
\end{tabular}


The Brazilian Cotton Industry has even started an export trade as will be seen from the following table:-

EXPORTS OF COTTON PIECE GOODS

MANUFACTURED IN BRAZIL

COTTON PIECE GOODS

\begin{tabular}{|c|c|c|c|c|c|c|c|c|}
\hline & \multicolumn{5}{|c|}{ KILOS } \\
\hline & & & & 1913 & 1915 & 1916 & 1917 & 1918 \\
\hline Manáos & .. & .. & .. & - & - & - & 2,863 & - \\
\hline Pará.. & $\ldots$ & .. & . & - & 500 & 568 & 1,327 & 900 \\
\hline Recife & .. & . & .. & 30 & - & - & 2,375 & 787 \\
\hline Bahia. & $\because$ & . & . & - & - & - & 1,781 & - \\
\hline Rio de Jan & heiro & .. & . & - & 1,560 & 1,365 & 5.343 & 48,594 \\
\hline Santos & .. & .. & .. & - & - & 3,921 & 4,645 & 59,216 \\
\hline Rio Grande & & .. & .. & - & - & - & - & 9 \\
\hline Porto Alegr & & .. & .. & 156 & - & - & - & 317 \\
\hline Sant'Anna & do I & ivra & nto & - & - & - & $1,00 ?$ & 1,093 \\
\hline Santa Victo & oria & lo 1 & nar & - & - & - & - & 352 \\
\hline São Borja & .. & .. & .. & - & - & - & - & 320 \\
\hline Uruguayana & & .. & .. & - & - & - & - & 1,367 \\
\hline Corumbá & .. & . & . & - & - & - & 13 & - \\
\hline Total & & .. & .. & 186 & $.2,060$ & 5,854 & 19,350 & 113,035 \\
\hline
\end{tabular}

\section{DESTINATION OF COTTON PIECE GOODS MANUFACTURED IN BRAZIL AND EXPORTED COTTON PIECE GOODS}

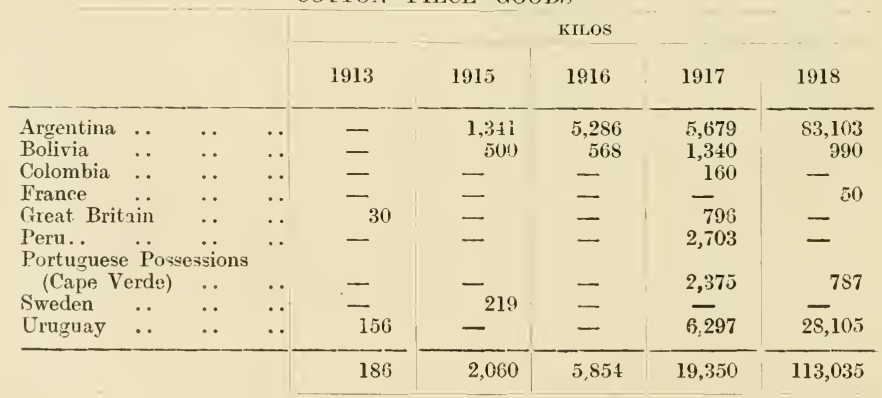




\section{Chapter III.}

\section{GENERAL REMARKS ON BRAZILIAN COTTON}

Several explorers soon after the discovery of Brazil report that the Indians in various parts were making different articles of cotton, and it is therefore to be assumed that cotton is an indigenous plant in several Brazilian States: some of these articles we saw in the National Huseum at Rio de Janeiro. A further reason why one

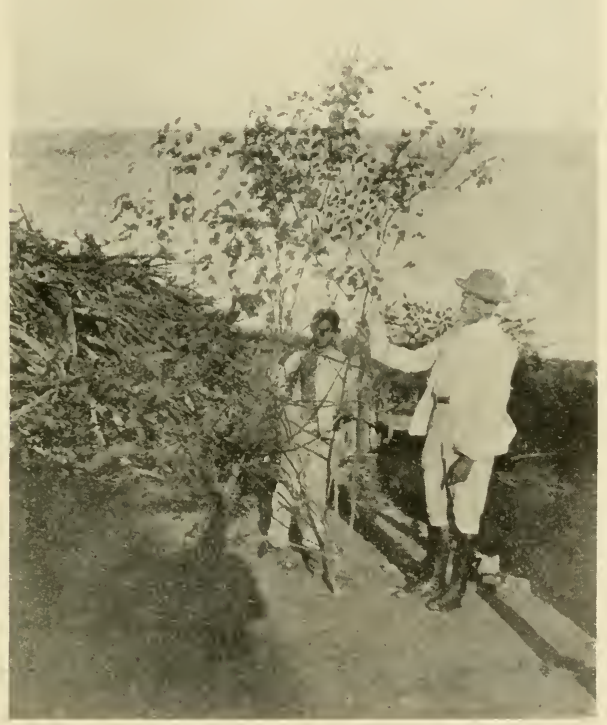

"Ganga" or Wild Cotton from the stony mountain tops in the Seridó District

must come to the conclusion that cotton is indigenous to Brazil is that a wild species, known as "ganga," or "Algodão Sylvestre," is even to-day found on some desolate mountains. One farmer in the Serido district of Rio Grande do Norte sent a man to the top of the mountain to bring down for our inspection one of these wild growing cotton trees, the fibre of which is never gathered because the plants 
are in such inaccessible parts. This "ganga" cotton is of a creamy colour, has fine glossy fibre, is pretty strong, but only $3 \mathrm{in}$. to length. The seed is almost naked, in its original state it has probably been entirely free from hairs ; its weight is only half that of an Egyptian cotton seed. The opinion is generally held in the Serido district that this cotton was the forerunner of the splendid "Moco " cotton, of which I shall speak at length when rlealing with the Sericlo district.

Cotton was cultivated in the early colonial times in Bahia, Pernambuco and Maranhão, first to supply the needs of the districts and gradually to supply the outer world. Indeed, during the War of Secession the exports of Brazilian cotton reached the important quantity of $80,000,000$ kilos $(355,000$ hales of $500 \mathrm{lbs}$ ). These ship)ments of cotton brought great wealth to the Brazilian planters who at those times had no one but slaves as their workpeople, but instead of stimulating them to further efforts with a view to establishing permanently the cotton growing industry, the planters squandered their easily gotten riches and allowed the Nortl Americans to regain their old preponderance. The North of Brazil reverted to sugar and the South to coffee. When in 1889 slavery was abolished all the large planters gave up cotton in the North and from that time onwards cotton was only cultivated in small plots, often to supply the domestic needs of the village only.

Cotton is to-day again of importance for Brazil : its own cotton mill industry with $1 \frac{1}{2}$ million spindles, spinning mainly coarse counts, requires ever increasing quantities. Brazilian economists realise that the exports of their country must increase if a sound financial position is to be achieved. In the last decades Brazil has committed the grave error of relying on one or two crops for the adjustment of her balance of trade. It was practically a question of " monocultivation," rubber and coffee being the only staple crops for erport purposes. Pubber in the Amazonas district is almost " played out." The plantation rubber of Asia has been found to be so cheap, that it does not pay any more to gather the milky juice from the wilds of the Amazonas. Coffee, of which three-quarters of the world's requirements are grown in Brazil, and in São Paulo in particular. is not finding its pre-war consumption, because the Central European markets, which were formerly Brazil's second best coffee customer, are not in a position to buy much : they have learnt to substitute various products for coffee, and the U.S.A., the best coffee customer, has been holding aloof for some considerable time, due, no doubt, to the aftermath of war ; in addition. Africa is increasing her output and likely to do so on a greater scale. Agriculturists and statesmen are, therefore, clamouring to substitute "poly-cultivation " for their former "mono-cultivation." Brazil has always been a sugar-growing country, but the average yields are not as favourable as those of other countries, such as Java; indeed, it was only during the war that sugar became again an export commodity of importance. There is no other crop which would seem to me more suited for Brazil to take up than cotton, the principal reason being that the vields por acre of lint in Brazil, especially in the state of São Paulo, are almost phenomenal. But not only São Paulo can boast of a greater average yield than any country, but also the North-Eastern 
part of Brazil. These are two distinct zones, the former growing American Upland of about one inch, which is planted every year afresh, whilst the latter zone produces real first-class long staple colton on trees which to not require renewing for 15 years and more. When one compares the vields of these two zones with those of any other cotton growing country in the world one cannot come to any other conclusion but that-in view of the general shortage of cotton in the world under normal conditions-cotton is bound to assert itself there. Not oniy in the above-mentioned parts of Brazil are the yields higher than anywhere else, but also in the States of Minas Geraes, Bahia, Alagôas and Sergipe yields are equal to, if not higher than, those in the U.S.A.

Hardly anything has been done to improve cotton cultivation in Brazil. The Cotton Department of the Agricultural Ministry is quite a new enterprise and could, of course, touch so far only the fringe of the prollem in the one and a half years of its activity, though hard work lias been done. It may sound surprising, but in almost every place I had to explain to the planters, farmers, nay, even to cotton merchants, what constitutes the quality or value of cotton; they did not know that the length, uniformity, strength, colour, ete., were the potent factors on which the price depends.

Therefore what Brazil has produced-and that excellent qualities are grown will be seen from subsequent chapters-has been achieved without the least human effort towards improvement. All is the spontaneous work of bountiful natural conditions. Man has retarded, has persistently caused a deterioration of the cotton qualities, through laxity or ignorance, as for instance in the ginning and planting of mixed cotton seeds in the same field.

So far the U.S.A. are Brazil's best customers for the bulk of her raw materials (but she does not buy much cotton from Brazil). As the U.S.A. import so largely from Brazil, this country has to treat North America with due deference and circumspection. Thus contracts for electrical undertakings, financial transactions, etc., pass often to the U.S.A. On account of the fact that this country takes most of Brazil's commodities. Brazil requires another string to her bow: if she succeeds in making cotton one of her staple products she will find a good customer in Europe to the mutual advantage of both parties.

The staple cotton of the North-East is well able to compete with Egyptian cotton, for even in Brazil it is used for spinning up to 1.25's without admixture of any foreign grown cotton, and, of course, the Brazilian is not as skilled as the Lancashice operative.

Shortage of Long Staple Cotton.--The Boll-Weevil has definitely invaded the long staple district of the Mississippi delta, with the result that 1 in. Bender cotton is to-day 1,000 points "on." It will be impossible, on account of this invasion, to grow long staple cotton in these parts during the next recarle, because cotton of quickly maturing characteristics must be planted in order to have it ripe before the boll-weevil has time to develop and so far no early maturing variety of long staple cotton has been found. Cotton of a short growing period 
is invariably of short fibre. In the Sea Island districts of the American Belt short cotton or no cotton at all has been planted for the same reason. The only other long staple district in the United States is on the Californian coast, the Arizona district, where Egyptian cottons are grown with considerable success under irrigation. This erop is principally ear-marked for consumption by the American tyre industry.

The "pink boll-worm " has commenced its invasion of the U.S.A., in Texas and Western Louisiana. The ravages of this pest are more devastating than those of the boll-weevil. This new threat to the American Cotton crop is another reason why cotton growing in all countries outside the U.S.A. should be fostered.

Egypt, on which the ever-increasing fine spinning section of the Lancashire mills depends mainly, shows alarming declines in the yield per acre and also to a lesser extent in the number of acres cultivater, as will be seen from the following figures:--

\begin{tabular}{|c|c|c|c|c|c|c|c|c|c|c|}
\hline & 1913 & 1914 & 1915 & 1916 & 1917 & 1918 & 1919 & 1920 & 1921 & \\
\hline AREA (feddans). & & & 1,186 & 1.656 & 1.677 & 1.316 & 1574 & 1.828 & 1,292 & \\
\hline $\begin{array}{c}\text { Crop (Bales of } \\
500 \mathrm{lbs} \text {.) }\end{array}$ & 1,537 & 1,298 & 961 & 1,022 & 1,262 & 964 & 1.114 & 1,200 & 700 & \\
\hline $\begin{array}{c}\text { Average Yield } \\
\text { Kantars (100 lbs.) }\end{array}$ & $4 \cdot 46$ & $3 \cdot 70$ & 4.06 & $3 \cdot 10$ & $3 \cdot 75$ & $3 \cdot 66$ & $3 \cdot 54$ & $3 \cdot 28$ & $2 \cdot 67$ & \\
\hline
\end{tabular}

Egypt's output is likely to be further affected by the political changes which are pending in that country.

The other sources of long staple cotton are the West Indies* and Peru, where in the short valleys of the rivers Egyptian cotton is grown, and the Northern States of Brazil where tree cottons are cultivated. The yields in Brazil are by far the highest of any cotton producing country, but the drawbacks are that the cotton is not sufficiently graded, that there is frequently a slight difference in the length of fibres from bale to bale and that one cannot always get repeats of the same quality. These are, however, remedial defects. The difference in price existing between cotton of such staple as Brazil offers and those of other origin is sufficiently great to warrant the trouble of special classification and additional cleaning in the mill.

Can we, in view of the threatening position of the long staple supply of cotton, which is likely to be short for a number of years, afford to neglect any possible source of supply? Does it not behove all, Lancashire in particular, to look around in good time for new fields that ean step into the breach. From what I have seen in the north-eastern part of Brazil I maintain that we have here a stretch of country able to come to our help; all that is required is administration and the initiation of a few elementary reforms, of which I shall speak later. The north-east of Brazil has no other erop which would seriously compete with cotton: the country is, indeed, dependent on cotton and for this reason the Governments of Rio Grande do Norte and Parahyba are anxious to do everything in their power to help those who are willing to undertake the extension and improve-

* About 4,000 b. p.a. 
ment of cotton. When cotton is a success in these parts, the resources of the States are also plentiful, as the revenue is a fixed rate on the value of eotton exported.

As to São Paulo, I hold the view that an extension there is bound to come, because cotton has been grown of late between the rows of the huge coffee plantations, and the old established coffee plantations are giving such low yields that unless artificial manuring is resorted to it will not be sufficiently remunerative to continue them. (See later chapter on Coffee.) The soil is exhausted after growing trees on the same spot for 40 and 50 years. Artificial manure is very costly and when a planter has to deal with a hundred thousand of trees (which is quite a common occurrence), it becomes difficult, if not impossible, to apply manures. Is it not natural that the coffee planter will give cotton a trial as an alternative crop, especially as practically all his labourers have had some experience in cotton growing? Should the frost again cut down the coffee trees, as was done in 1918 , ${ }^{*}$ we shall certainly see a huge increase of the eotton aereage of São Paulo. The low prices of cotton have had a deterring influence, but when São Paulo merchants begin to grade cotton, as is done in the North, they will be able to obtain higher priees for their commodity. Another reason why eotton stands a good chance in the South is that coffee requires many more labourers than cotton and the labour question is an acute problem as far as coffee is concerned.

"Alagôas" and "Sergipe," though not so far producing a longer fibre than about lin. have the great advantage that these annual American Uplands require there only three months from the time of planting to picking. I am informed by the chief of the Brazilian Cotton Department that in Maranhão (where I have not been, so far), this period is reduced by half, i.e., in $1 \frac{1}{2}$ months from planting the cotton can be gathered. There is no other country in the world where in so short a period eotton ean be grown.

The State of "Bahia" is at present producing a small quantity, which should, however, be enough and of sufficiently good quality to provide the cotton mills existing there without recourse to the importation of cotton from the other States.

"Minas Geraes" is too far away from the ports-the steamer and railway freights, under the present conditions, make it impossible for this cotton to compete with others from nearer the coast. Minas eotton will have to be used exclusively by the mills established in that State and by the local hand spinners until better means of communication are established. It is quite a good cotton of about lin. and more in some places.

There is no need for me to speak as to the suitability of climate and soil ; the yields, which will be mentioned in detail in later chapters prove up to the hilt that these eonditions are absolutely right. I may mention that generally there are decided periods of rain and dry weather. It is during the dry weather that the picking takes place.

Particulars of rainfall and temperature are stated in the chapter on Geography.

*Severe frost comes periodically, but never whilst cotton is on the trees. 
Drawbacks.-Besides these advantageous conditions there are also some drawbacks affecting cotton growing in Brazil.

In the first instance there is the scarity of population, but, as remarked previously, in São Paulo the cotton extension is likely to take place in the coffee growing districts where at present a sufficient population exists for dealing with eotton, though it may not suffice for coffee. Furthermore, this part of Brazil is the centre of attraction for the influx of immigrants and São Paulo, the most enterprising and well-governed State of Brazil, will see to it that immigration continues. Under present unsatisfactory conditions in Europe we must expect an increased rate of immigration.

The northern part of Brazil, owing to the character of the cotton plant being perennial does not require anything like the labour which annual cotton necessitates. Generally only one clearing of weeds is unclertaken, at times two, but during the period of pieking there is undonbterly a seareity of hands. Fortunately this can be remedied for large numbers of the hard-working and frugal population of Ceará have been, in the past, accustomed to collect the rubber in the districts of the Amazonas. Since rubber ean no more compete on a large seale with plantation rubber from Asia, work will have to be found for these Cearense rubber gatherers and nothing is more natural than that they should migrate to Pio Crande do Norte, Parahyba, ete., which are situated at a short distance from their native heath and where the elimate is magnificent compared with the Amazonas.

Next to the scarcity of population the giming is seriously at fault.

Ginning.- The following is a list of the cotton ginning machines of Brazil, as per official returns of 1916 :-

DRIVEN BY

STATE

TOTAL

\begin{tabular}{|c|c|c|c|c|c|c|c|c|}
\hline \multicolumn{2}{|c|}{ STATE } & \multirow[b]{2}{*}{ STEAM } & \multirow[b]{2}{*}{ ANIMAL } & \multirow[b]{2}{*}{ HAND } & \multirow[b]{2}{*}{ WATER } & \multirow{2}{*}{$\begin{array}{l}\text { ELECTR1- } \\
\text { CITY }\end{array}$} & \multirow{2}{*}{$\begin{array}{c}\text { NOT } \\
\text { STATED }\end{array}$} & \multirow{2}{*}{ TOTAL } \\
\hline & & & & & & & & \\
\hline Alagôas & .. & 107 & 4 & 4 & 4 & 一 & - & 119 \\
\hline Bahia & .. & 12 & 54 & 9 & - & - & - & 75 \\
\hline Ceará & .. & 112 & 151 & 5 & - & - & - & 268 \\
\hline Maranhão & . & 38 & 47 & 56 & - & - & - & 141 \\
\hline Minas Gera & es & 6 & 21 & 3 & 3 & 5 & 2 & 40 \\
\hline Pará .. & .. & 2 & - & - & - & - & - & 2 \\
\hline Parahyba & .. & 194 & 94 & 1 & 1 & - & 一 & 290 \\
\hline Pernambuer & ... & 112 & 57 & 4 & - & - & - & 173 \\
\hline Piauhy & $\because \quad \cdots$ & 14 & - & 8 & - & - & - & 22 \\
\hline Rio Grande & do Norte & 190 & 78 & - & - & - & 3 & 271 \\
\hline São Paulo & . $\quad \ldots$ & 24 & 1 & - & 12 & 16 & - & 53 \\
\hline Sergine & .. & 62 & 1 & 7 & - & - & - & 70 \\
\hline & Cotals & 873 & 508 & 97 & 20 & 21 & 5 & 1.524 \\
\hline
\end{tabular}

All these machines are small saw-gins, some containing only is blades, but the average is perhaps 36 . They are of the usual Americar gin type, generally the "Eagle" mark; 90 per cent. of the saw-gins are absolutely blunt. I must have inspected at least 250 ginning machines in different parts of the country ; I came across one still being used which har not been adjusted for 16 years and it was 


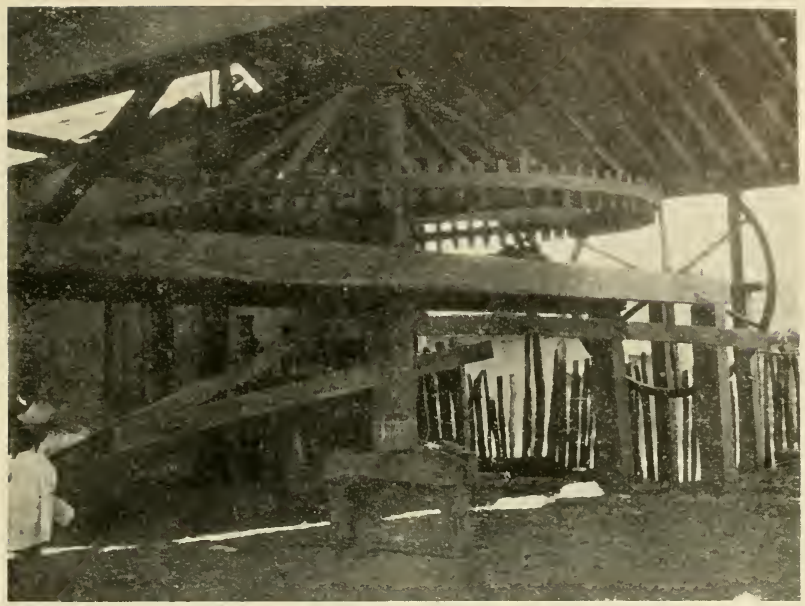

The driving arrangement of most of the ginning factories in the Interior.

(A mule drives the machinery, the velocity of the gin depends, of course, on the speed at which the mule walks round the "bolandeiro" as this contrivance is called.)

quite a eommon thing to find that the saws had not been touched for four or six years. When one consider's that these saws should be filed twice or three times a season. one will readily recognise that the existing Brazilian gins must damage the fibre. In order to demonstrate this fact I had one and the same quality of cotton ginned by a saw-gin and by a small hand roller gin. The lint turned out by

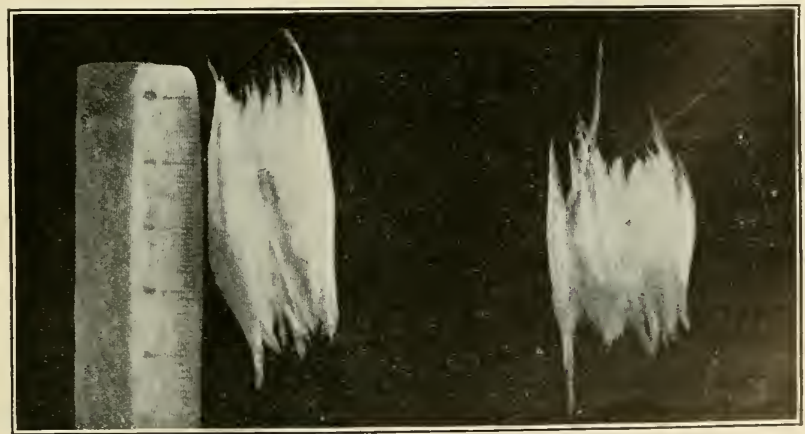

One and the same cotton, the one on the right is from a saw-ginned sample, and the one on the left from a sample passed through a hand-roller gin 
the latter measured practically $35 \mathrm{~mm}$. whilst the fibre from the sawgin was only 27 to $29 \mathrm{~mm}$. These two samples I had mounted cn a eard and showed them at all our meetings of Government officials, planters, farmers, ginners, etc. This is clearly a case where human laxity and indifference reduce the value of the fibre which Nature lias provided. What would America or Egypt give if they could increase the length of their fibre by slight reforms in the ginning processes by, say, $5 \mathrm{~mm}$.? Botanists are pleased if, after years of seed selection, they can ohtain an increase in length of $2 \mathrm{~mm}$.

In this connection I must state that the lengths of fibres mentioned by me in the whole of this report are those of fibres pulled by me from the seed. Once seed cotton passes through a Brazilian gin, you can never be certain, how much of the length is cut off.

Since 1916 to which the table on p. 56 refers, some real up-to-date ginning factories (14) have been erected. Each factory has from two to four gins, bearing from 60 to 80 blades. Suction pipes are provided for the transportation of seed cotton and the lint is also conveyed in pipes to the presses. All these modern gins are also of the American saw type.* They are only just beginning to work and, no doubt, more regular and cleaner cotton will be the result. Thirteen of the above-mentioned factories are situated in the North and have been built by three concerns with the help of Government concessions. In practically all cases the Government gave considerable loans at a reduced rate of interest and made abatements, for a number of years, in the rate of the export duties on cotton handled by these factories. (See statement at end of chapter dealing with the "Export Houses of Pernambuco, Parahyba and Rio Grande do Norte.")

Similar concessions will be given to any respectable firm and I have been requested by the Governors of Parahyba and Rio Grande do Norte to emphasise this point, with a view to inducing the establishment of some concerns with the help of European capital in these parts of Brazil.

The fact that Brazilian gins are turning out rlamaged fibres is perhaps a lesser evil than the mixture of the seed, which the ginning factories, as a rule, sell to the farmers. There is not one ginning factory which, so far, has supplied a uniform seed of one variety. The heaped-up piles of seed which we saw in the factories and from which the seed is taken that is supplied to the cultivator for planting purposes, is a mass of from five to eight different kinds of seed. Fortunately, every variety can easily be recognised and it would only require the labour of a child to undertake the separation of the different kinds. Users of Brazilian cotton have frequently complained of the irregularity of fibre and undoubtedly this mixing of the seed is the main cause of it.

Establishment of Cotton Seed Farms.- I have very urgently insisted with the Federal Government that they should undertalie the establishment of cotton seed farms, if possible one variety of seed

*At one factory in Parahyba two Platts' roller gins had been erected, but at the time of my visit they were not quite in working order. 
only for each district, and I have the promise that something will be done, but the vastness of the country, aggravated by the lack of communication makes it expedient that all ginners must co-operate in this direction. Much ean be achieved by private enterprise. Inderl, in a country like Brazil, it is very questionable whether such work as the distribution of seed could be efficiently undertaken by the Government. Brazil is governed on very democratic lines. With every change of President, which occurs every fourth year, the principal heads of the departments change as well and often the new Minister decides to discontinue certain work which his predecessor had undertaken. It may occur, when the present Government goes out of power, that the Cotton Seed Farms and Experimental Stations planned and already established may be discontinued. Continuity of action is the bed-rock of success in the distribution of pure seed, and it is in this direction that the International Cotton Federation might be of great help, either by establishing jointly with the existing firms in Brazil and with Government concessions their own ginning concerns and seed farms, or by interesting financial and other houses in such a scheme.

Establishment of Ginning Factories.-I have not in mind that the International Federation should undertake the growing of cotton on a large scale, but I think that by establishing roller gins, first in the long fibre growing districts, and perhaps buying cotton at a fixed premium over local rates for clean picked cotton, raised from the seed that has been distributed, a real benefit would accrue, not only to the spinning industry but also to the growers of cotton.

I am adverse to such an undertaking growing cotton on a large scale, because it has been proved in many countries that cotton is best grown by the small eultivator. Further, the purchase of land, on anything like the necessary scale, would be a means of raising the price of land in advance, and $I$ also hold that agricultural work does not fall within the limits of the activities of spinners. It is another thing altogether when we come to the purchase of raw cotton. If, by some unfortunate incident, the crop in a year should be very small the company that undertakes solely the ginning and perhaps the buying does not lose much, whilst in times of heavy harvests the ginning company would benefit accordingly. In any case, by leaving out the actual growing of cotton one eliminates one great risk and at the same time one can achieve through the distribution of pure selected seed and by running a small experimental plot, the same beneficial results for the district as by undertaking the actual planting of cotton.

On the question of seed farms, the necessity of picking cotton clean, the establishment of markets, ginning by roller-gins and mixture of seeds, I refer the reader to the lecture I gave before the National Agricultural Society of Brazil at Rio de Janeiro, of which a trans. lation will be found in the Appendix.

The Production of Roller Gins as Compared with Saw Gins.In consequence of an interview with Messrs. Platt Brothers \& Co., Ltd., whose roller gins are extensively used in Egypt and India, they have 
written me the following letter which will be specially instructive to those who intend to establish roller ginning factories in the Northern parts of Brazil :-

"As we understand the bulk of the cotton grown in Northeastern Brazil is of the clean or Black Seed variety, we have compared the production of a 50 -saw gin with that of a roller gin of the single-action type, each machine being fitted with automatic feeders. We have further assumed that each machine forms a unit in a scheme for automatically conveying the ginned cotton to the baling room.

"One single-action (single roller) gin, 40in. wide, should average throughout the day $130 \mathrm{lb}$. int per hour.

"One 50 -saw gin with $12 \mathrm{in}$. saws should average throughout the day $450 \mathrm{lb}$. lint per hour, or a production rate ratio of $3 \cdot 4$ to 1 .

"If a woolly seed cotton is being ginned this ratio would probably rise to say 5 to 1 owing to the more positive action of the saws in detaching the fibre from the seed.

"In the latter case we have made our comparison with a $40 \mathrm{in}$. double-action (single roller) gin as being a more suitable machine for ginning woolly seed varieties.

"We should expect the production to be about 701b. per hour for the roller gin as against approximately 350lb. per hour for the saw gin. The relative advantages of the two types of machines depends entirely on the line of view taken. From a production standpoint the saw gin is of course well in front of the roller gin : the question ginners have to decide is whether it will pay to sacrifice output for quality.

"In a district or tract of country where the weight of woolly seed cotton grown is very great and the fibre of only moderate length as in Southern Brazil (São Paulo), the number of roller gins would have to be so large, together with the increased cost of installation, upkeep and labour that preference would be given in those parts to the saw gin.

"As regards long stapled cottons (we refer to the black seed varieties) no one in their senses would ever dream of ginning these on a saw gin as the result would be absolutely ruinous both to the even length of the fibre as well as its general appearance: the very fact of these fine cottons being torn from their seed and then dragged through the grate bars in the roll box cannot otherwise but seriously damage it.

"The roller gin treats these cottons in a far different manner, the action of the roller gently detaches the fibre from its seed and retains to its fullest extent the length of the staple; the action of the roller also assists very materially in giving to the cotton that silky appearance which is such a feature in all betterclass cottons. To enable you to make a comparison between the cost of the different types of machines, we have pleasure in giving herewith the respective prices of these machines, viz:- 
(1) Patent Single-Action Macarthy Cotton Gin, 40in. wide, with 5 bearings, crankshaft $1 \frac{1}{4} \mathrm{in}$. diam., and fitted with Platt's Patent (Drawback) Feeder. (Seed Grid with open ends and Wood Stripper Roller) as per circular. Price $\mathfrak{f 4 2} 15$ s., plus 195 per cent.

(2) Patent Double-Aclion Macarthy Cotton Gin, 40in. wide, with 5 bearings, crankshaft $1 \frac{1}{2} \mathrm{in}$. diam., and fitted with Seed Grid with open ends, Wood Stripper Roller and Platt's Patent (Drawback) Feeder, as per Circular. Price $£ 4410$ s., plus 195 per cent.

(3) 50-Saw Gin, with 12in. Saws, complete with Feeder and Condenser. Price $£ 100$, plus 195 per cent.

Packing in Cases and delivery alongside ship at port charged extra on the gross prices, viz:

Manchester, $17 \frac{1}{2}$ per cent.

Liverpool or Birkenhead, $18 \frac{1}{2}$ per cent.

Platt Brothers \& Co., Ltd., do not hold themselves responsible for any breakages which may occur in transit after delivery of the cases in good condition to the shippers.

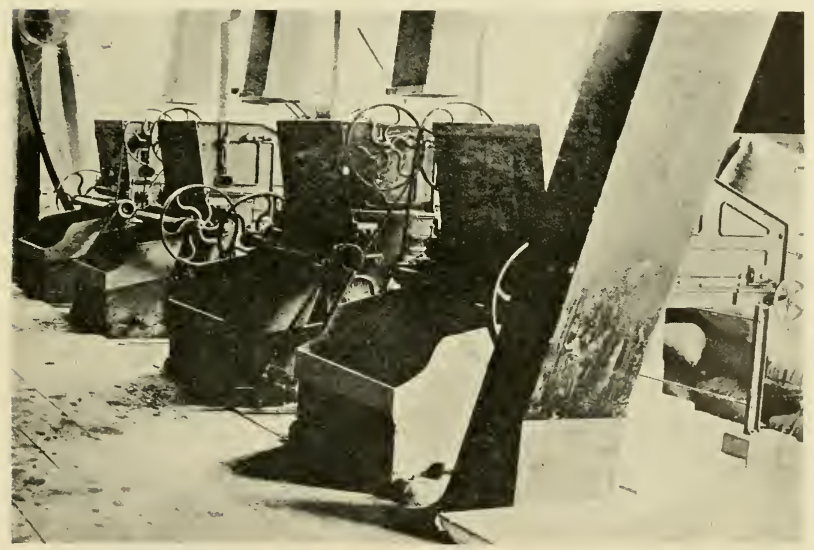

\section{A MODERN ROLLER GINNERY IN PERU}

This illustration represents a 4-roller gin outfit and is completely automatic in its operation right from feed to condenser in press house. The seed cotton is fed down a chute from the room above; as the cotton falls from the ginning roller it is directed into the line of draught from a fan through the medium of a vacuum hox; the working portion of this box simply consists of a leather bladed roller driven from the gins, as shown. This roller revolves in close contact with the sides of the box and deposits the cotton into the suction pipe, through which it is drawn to the condenser and delivered to the press in a similar way to that of the usual saw gin factory 


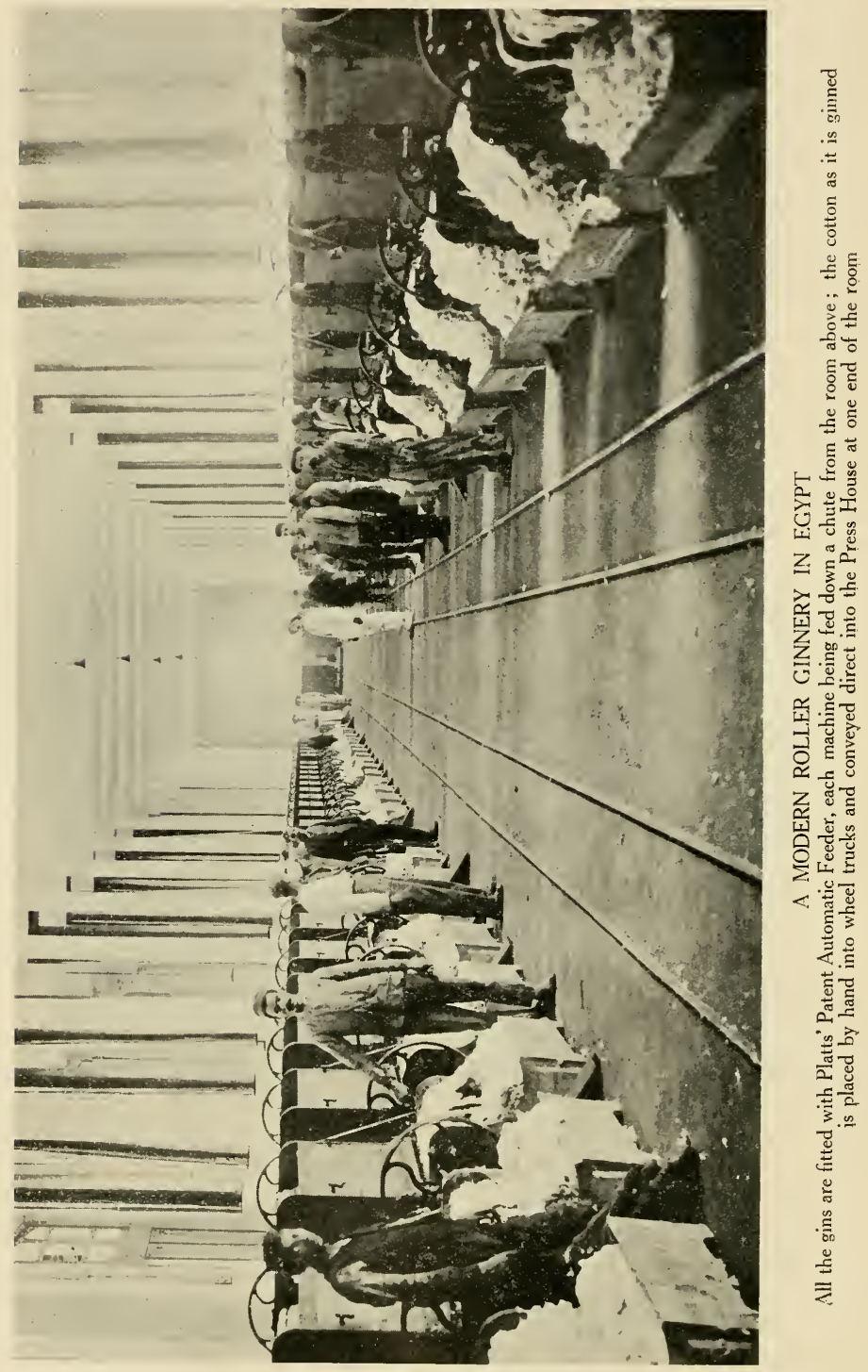


"We regret that we cannot give you the completc cost of an entire installation to eomprise suction piping. fans, condenser. etc., as we have not, up to the present, ereeted any of these plants: the photographs of ginneries which you were shown, were those of factories in Peru that had been equipped by the Murray Company, U.S.A. : we mean so far as the distribution and conveying of the material to and from our gins. We have it on the authority of our agents in Peru that the system has realised everything that wat expected from it and is working very successfully. They inform us that in a factory containing 24 machines, where formerly the personnel used to he thirty, the total number of people now employed is only seven, with a corresponding increase in output of 50 per cent.'

Necessity of Recognising Quality and Grade.-The great difficulty which will have to be overcome is the recognition of greater value on the part of the Brazilian buyers of local eotton as regards clean over dirty cotton, long over short fibres, uniform over irregular staple.

This is espeeially the case in São Paulo and Minas. Unfortunately the Exchange at São Paulo does not differentiate enough as to these qualities and consequently the small buyers in the interior clo not trouble either about these matters, but pay one uniform price for all cotton, no matter in what state it is. When we visited the São Paulo Exchange I asked for their standard samples. Instead of bringing these in a well protected case, they put before us three samples, tattered and torn, wrapped up in dirty old brown paper. The knowledge of cotton is not yet sufficiently appreciated; probably there has been no need to bother about these different points, as the cotton mills have not been sufficiently insistent on getting elean and uniform cotton. There is no firm to my knowledge in são Paulo, which thoroughly grades the cotton, as is done in the north-east and this is probably at the root of the evil. It would pay the spinners of the south to announce to the growers of cotton that they will be prepared to pay a certain premium over and above the local market rates for clean and uniform cotton. The spinners would gain by sueh aetion as they would reduce their waste in the mills. This is a suggestion for the two Millowners' Associations of Rio and São Paulo to act upon. Let the São Paulo Exchange make up standard samples - in sueh a manner as they ought to be-and make it generally known that for a eertain type they will pay in the coming season 5 or even 10 per eent. premium. In Bahia the millowners are more drastic, they accept first-class at the market rate. but dirty cotton only with a reduction of about 50 per cent. In Parahyba the difference between first and seconds is similar; real dirty cotton could not be sold at all for spinning purposes and had to be sent to paper mills.

Insect Pests. - A few remarks remain to be made under the heading of "General Notes on Cotton" as regards the insect pests.

The problem of defending a country against the introduction of cotton pests shows the neeessity for combined action in all the cotton producing countries. For one country to take measures is helpless, as the history of the pink boll-worm elearly shows, and it would appear

* Reproduced on pp. 61 and 62. 
to me that the forthcoming Cotton Congress at Rio de Janeiro, which will be held in October, 1922, in connection with the Centenary Independence Festivities, might appropriately deal with this very important subject.

The boll-weevil (anthonomous grandis)* came from Mexico in 1892 to Texas and in spite of rigorous measures has now covered the whole of the United States' cotton belt. The pink boll-worm was brought from India to Egypt, from there in a cargo of cotton seed to Brazil, thence in the same manner to the West Indies and in 1917 to the U.S.A. Mr. Maxwell Lefroy, Professor of Entomology at the Imperial College of Science and Technology, London, stated recently that "it was quite natural that America should have decreased its area of cultivation by one-third. The growers have all the expense of preparing the ground and growing the crops and there is no means of telling until the last moment that the crop has been infested. If in addition to the loss of 30 per cent. of her cotton crops through the boll-weevil, she is to suffer a 17 per cent. loss through boll-worm, America can hardly be expected to continue growing cotton." The pink boll-worm is the more difficult of the two pests to deal with because it forms into a moth which has a big range of flight, thus the West Indies received the invasion through a cargo of seed cotton which lay in one of the West Indian ports and from this the moth flew ashore. In the caterpillar state it coils itself up in the seed and may live there for more than two years.

Entomologists state that the following cotton pests exist in Brazil :

Hemiptera. Pyrrhocoridae.

, Lygaeidae.

,

,

,

,

,

,

Coleoptera.

,

,, Orobitidae.

Lepidoptera. Gelechiidae.

Noctuidae.

,, $\quad$ Arctiidae.

,

," $\quad$ Pyralidae.
Tingitidae.

Aphidae.

Coccidae.

Lygaeidae.

Chrysomelidae.

Mylabridae.

\begin{tabular}{|c|c|}
\hline Dysdercus ruficollis & \\
\hline Plociomerus, sp. & . \\
\hline Oncopeltus, sp. & \\
\hline Gargophia, sp... & \\
\hline Aphis gossypii.. & - \\
\hline Saissetia depressa & . . \\
\hline \multicolumn{2}{|c|}{ Hemichionaspis minor } \\
\hline Nysius ericae .. & . \\
\hline Colaspis, sp. . . & $\ldots$ \\
\hline \multicolumn{2}{|c|}{ Spermophagus hoffmanseggi } \\
\hline Gasterocercodes go & \\
\hline
\end{tabular}

Plainedra gossypiella . .

Alabama argillacea .. ..

Utetheisa ornatrix . . . leaf.

bella .. $\quad \ldots \quad \ldots$,

Ephestia cautella $\quad$. $\quad$. . seed.

The pink boll-worm (gelechiidae), known in Brazil as "lagarta rosada," had devastated a large part of the crop, especially in São Paulo, in 1919, and the Government took energetic steps to overcome this pest by insisting on fumigating chambers being established at the ginneries and by netting in all apertures in stores where seed was

* The American boll-weevil must not be confounded with the pink boll-worm, as it is a beetle that walks about or flies only at a short range. 
kept with a view to preventing the escape of the butterflies. Latterly elaborate machinery has been installed at a few centres by the Cotton Dapartment for treating the seed in a similar way to that used in Egypt. The pink boll-worm is said to be a new plague that has been brought into Brazil with some Egyptian seed that was to be grown as an experiment. As is usual with insect pests, the havoc caused at the outset is the most formidable, later on, in a country with such large varieties of insects as Brazil is, natural enemies find these new insects. It is certainly astonishing, how little damage was done last season by the pink boll-worm with the exception of a few places. Of course a great campaign against this particular insect was organised by the Government and by many societies on account of the great damage done and in consequence agriculturists have given the matter a great deal of thought. I came across several cultivators in various parts who told me that they attributed the practical disappearance of the pink boll-worm to a very simple method they had employed. They had spread out the seed to be planted in the mid-day sun for about three hours (not more), at a temperature between 60 to $68^{\circ} \mathrm{C}$.; some had mixed with the seed sand and also charcoal for the purpose of better retaining the heat. I was told that quite 90 per cent. of the insects are killed in this way. The Professor of Agriculture at the "Luiz de Queiroz" College, Dr. Carlos Teixera Mendes, gave me to understand that his previous year's crop had suffered from 40 to 50 per cent. from the pink boll-worm, whilst this year, after applying the above simple means, he did not think he would lose 4 per cent. of the crop through pink boll-worm. This gentleman had hit on this idea of spreading out the seed in the sun, but evidently other people in the interior in the north had simultaneously acted in a similar manner with equally good results. Professor Green of Natal assured me that he had found parasites of the pink boll-worm and he had recently taken specimens to Washington (U.S.A.) for classification, particulars of which were not available at the time of my visit.

The other insect plague from which Brazil suffers, especially São Paulo, is the cotton worm (Alabama argillacea), known locally as "curuquerê." The Agricultural Department has supplied large quantities of Paris Green through its branch offices, together with appliances. The worm does not, as a rule in the south, come out until the bolls are formed and begin to open, if the plants are sprayed in the early stages. Once this stage has arrived it cannot do much damage. (The worm feeds entirely on the young leaves and shoots.

The insect pests of Brazil are no more harmful than in any other country. Though the list of cotton insects may be formidable, one never hears a planter or farmer mention any other insect than the pink boll-worm (lagarta rosada) and the cotton worm (curuquerê), evidently the others are doing very little damage.

Cotton Exports.-The following table was supplied to me whilst in Brazil by the Cotton Department of the Agricultural Ministry; since my return I have received the "Economical Notes" issucd by the Bureau of Information from the same Ministry, which contain a list with different figures. I therefore, append this list, especially as the values are stated. 


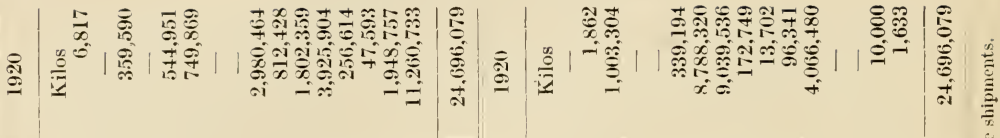

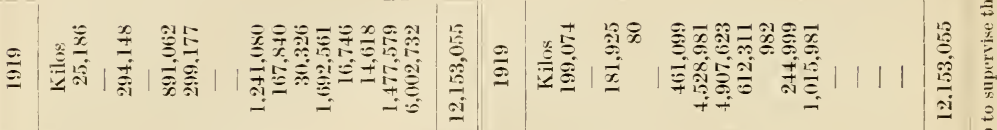

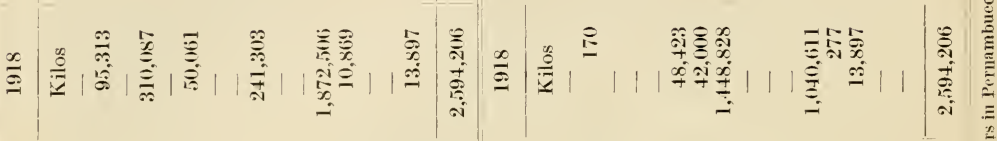

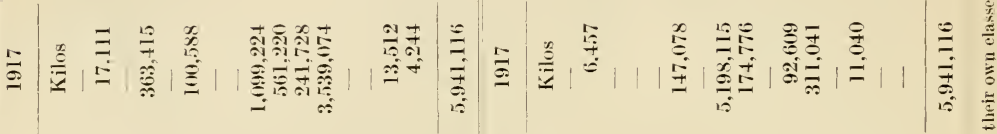

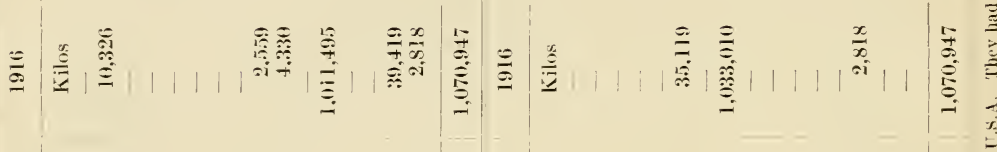

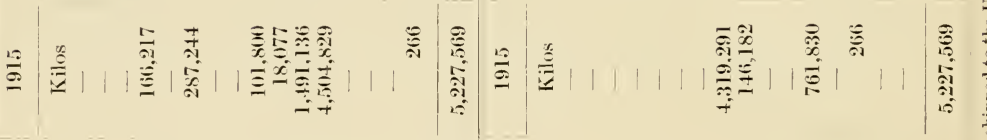

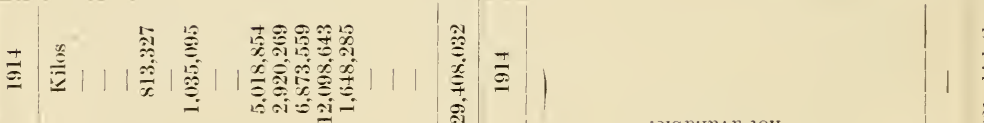

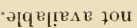

поำu!̣saCI

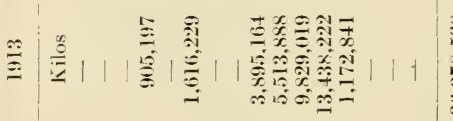
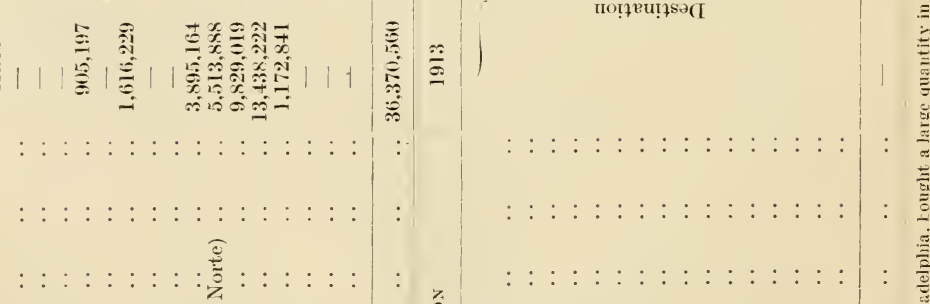

.

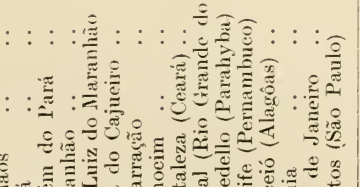

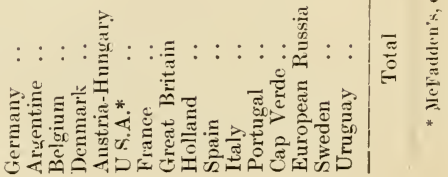


The two tables show that the State of São Paulo has, in the Iast few years, developed an export trade. The eotton which figures in these lists as coming from Recife (Pernambuco) is not all grown in that State. Pernambuco is the shipping port of a great deal of cotton grown in the States of Parahyba and Rio Grande do Norte.

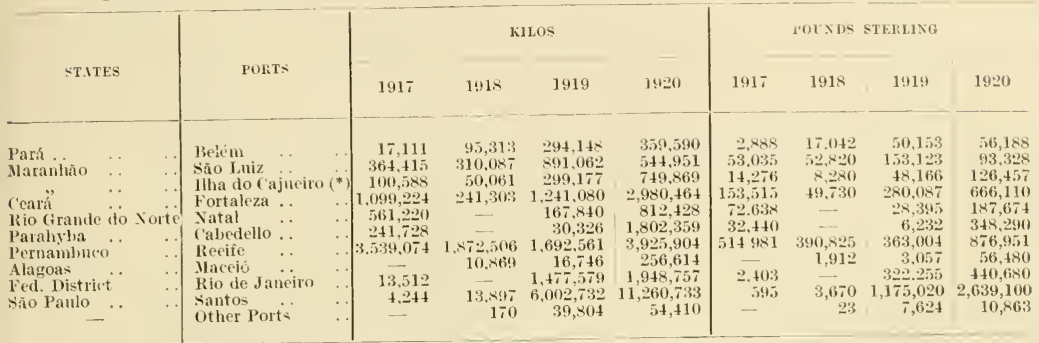

(*) Export- from the state of Pianhy are made hy the port of tha do tajueiro.

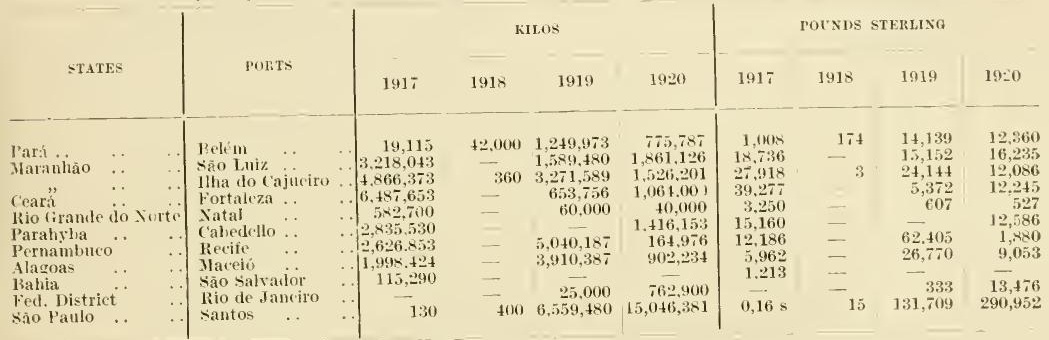

The Annual Cotton Mill Consumption in Brazil is estimated at about 553.700 bales of $500 \mathrm{lb}$. at the present time. It will not suffice to add merely the export figures to the mill consumption, in order to arrive at the total production of cotton in the country. There will have to be added the considerable amount used by handspinners in the interior, for it must be remembered that where there is no railway many houses have a garden in which cotton is grown for the domestic use. The consumption by hand-spinners and the quantity used for quilts, bedding, boats, * etc., can safely be estimated at $80,000$ bales of 500$) \mathrm{lb}$. If we calculate therefore the total production of cotton in Brazil as being to-day 450,000 bales of $5001 \mathrm{~b}$., we shall not be far wrong. This is, of course, only a "bagatelle " in comparison with what a country of such dimensions, soil and climate could produce, even with her present small population.

In the foregoing chapters and in the lecture delivered at Rio (see Appendix) I have tried to give a general view of the cotton cultivation in Brazil, but as generalising is somewhat unsatisfactory when dealing with so vast an area, a clearer impression will be obtained from the study of the following chapters dealing separately with each State.

* Cotton is pressed between the planks of boats to render them watertight. 


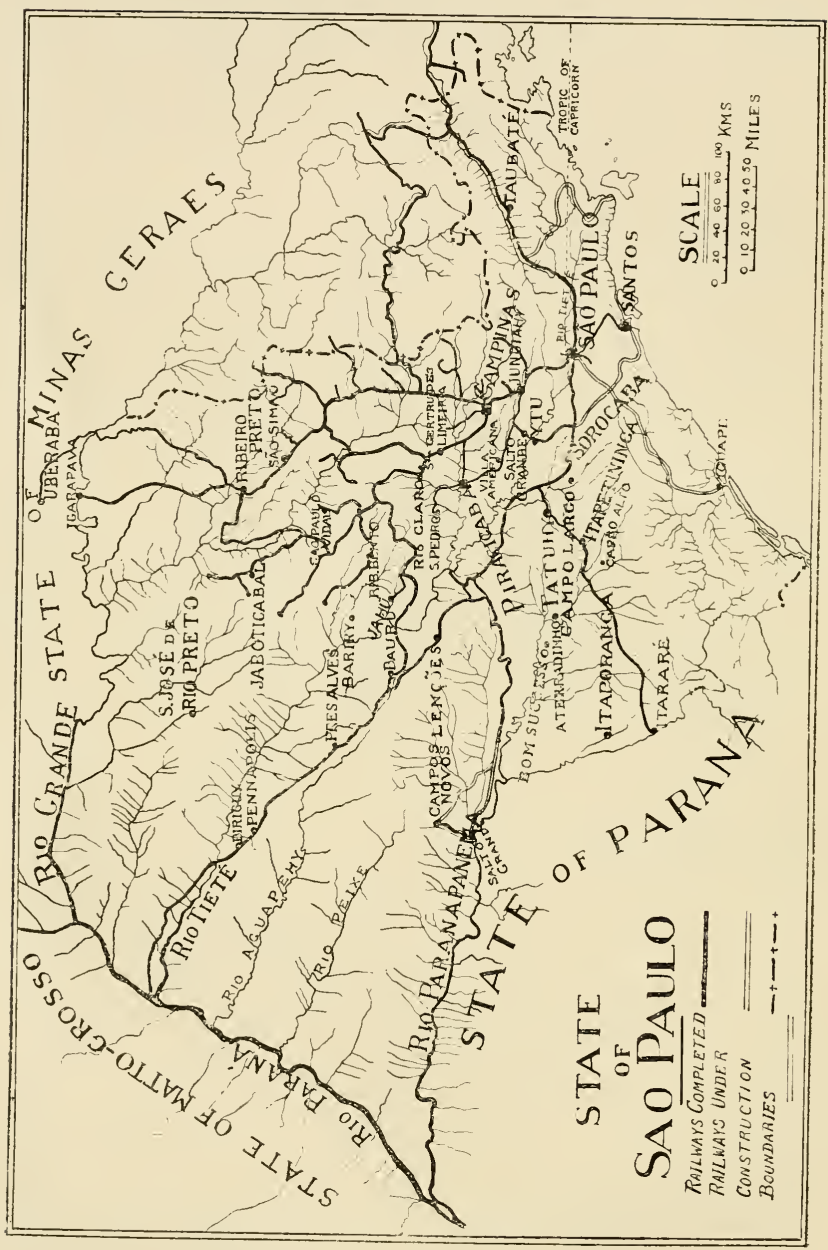




\section{Chapter I V. \\ STATE OF SÃO PAULO}

Area : $290,876 \mathrm{sq}$. kilometres (112,307 square miles).

Population: About $3,000,000$.

São Paulo adjoins the territory of Rio de Janeiro in the south. It is bordered on the east by the Atlantic Ocean; in the south by Parána; on the west by Matto Grosso and in the north by Minas Geraes.

The State of São Paulo is as large as half France; almost equal to the British Isles. Its area exceeds that of Italy and equals that of Belgium, Holland, Denmark, Switzerland, Portugal and Greece, all combined.

The State receipts of São Paulo are larger than those of 26 independent countries, amongst which are those of Denmark, Switzerland and Portugal. The imports of the State in 1919 were $381,014,790 \$ 000$ and exports $1,087,466,000 \$ 000$.

When the Republic was declared in 1889 the imports and exports of the whole of Brazil amounted to only 473,590,000\$000.

The following statistics of the international trade of the State of São Paulo speak for themselves of the enormous importance of this State to the Union of Brazil.

$\begin{array}{cccc}\text { YEAR } & \text { IMPORTS } & \text { EXPORTS } & \begin{array}{c}\text { EXCESS OF I:XPORTS } \\ \text { OVER IMPORTS }\end{array} \\ 1890 & \$ & \$ & \$ \\ 1895 & 23,318,403 & 143,244,(181 & 119,925,676 \\ 1900 & 72,422,479 & 279,615,833 & 207,193,354 \\ 1905 & 76,268,816 & 270,100,584 & 193,831,768 \\ 1910 & 78,372,959 & 220,230,469 & 141,857,510 \\ 1915 & 141,799,919 & 282,142,602 & 140342,683 \\ 1919 & 156,886,816 & 465,212,904 & 308,326,088 \\ & 381,014,790 & 1,087,466,000 & 706,451,210 \\ & (= \pm 25,400,986) & (=£ 72,497,333) & (=£ 47,096,747)\end{array}$

The imports and exports of the whole of the U.S. of Brazil during 1919 and 1920 were as follows: ( $£$ sterling)

$$
\begin{array}{lllllll} 
& & & 1919 . & & & 1920 . \\
\text { Imports } \ldots & \ldots & \ldots & £ 78,177,000 & \ldots & \ldots & £ 125.005,000 \\
\text { Exports } \ldots & \ldots & \ldots & £ 130,085,000 & \ldots & \ldots & £ 107,521,000 \\
\text { Total foreign trade } & \ldots & £ 208,262,000^{*} & \ldots & \ldots & £ 232,526,000
\end{array}
$$

From a comparison of these figures it is easy to realise what a powerful position the State of São Paulo occupies in the Federation of Brazilian States. Indeed, it has often been said that São Paulo aims at a saparation from the Union. but any secession movement does not carry much weignt. It is true that many people of the south

* São Paulo's share was almost half. 
are dissatisfied with the rate of progress of the north, but they do not seem to take into consideration all the circumstances. The Southerner knows very little of the true facts of the north and the reverse also holds good. The vastness of the country makes the spread of knowledge of the conditions difficult.

In this connection I may state that I have never met such a strong spirit of local or "State" patriotism as in Brazil. A Paulista will be extremely proud of having been born in that State of advancement and progress, but so will the Northerner uphold his State. I used to say to a Cearense in our company that he was a great lover of Ceará, almost to such an extent that he became an enemy to the rest of Brazil. This local patriotism or clannishness has been developed in such a measure that those born in one Statc have become prejudiced and cannot readily recognise the advantages existing in other States. Thus the head of a business concern will give preference in his dealings and in the employment of his staff to persons born in the same State as himself.-I trust my Brazilian friends will pardon this criticism, but it is a trait in the Brazilian character which is so pronounced that it must react unfavourably in the opening up of the country as a whole.

São Paulo is no doubt the richest State of the Union of Brazil financially and its credit in the London financial market is very high. It will be admitted that São Paulo is the best organised State of the Union. It has over 6,000 kilometres of railways.

The present President is Dr. Washington Pereira de Sousa, who received the International Cotton Mission and showed that he recognised the importance of cotton for his State as an alternative staple crop to coffee.

The Paulistas are well known in Brazil as the most enterprising people and often they are likened to the "Yankee " of North America. It is said that this courageous spirit of enterprise is the inheritance from the "Bandeirantes" (the Paulistas of the 17th century) who explored practically the whole of Brazil in search of gold, silver and precious stones.

With the exception of the small narrow stretch of land along the coast near Santos, the greater part of the State forms a huge plateau rising precipitously close to the port of Santos in the mountain range known as "Serra do Mar," to 1,000 metres or more, in undulating rolling country. Great portions of São Paulo in the north-westerly part are still covered with huge virgin forests.

The textile industrv, though already of considerable dimensions, not only in the capital of São Paulo but also in the interior of the State, is rapidly increasing.

The agricultural industry is growing by enormous strides, indeed its extension is merely dependent on the influx of immigrants. The cultivation of coffee is, of course, the essential crop of the State, and at the end of this chapter some facts and figures relating to coffee will be found.

A State whose citizens have understood enough to develop the coffee growing industry to such a perfect organisation. as is maintained 
in São Paulo, is able to extend the growing of cotton on sound commercial lines.

Santos, the great port of the State, which some 25 years ago was famous for epidemics of yellow fever, has eleared out all mosquitos, and with them this terrible disease has disappeared. There has not been a case of yellow fever in Santos for several years, and to-day it is probably the finest seaside resort in the whole of South America.

There are extensive quays, provided with the latest automatic transporting machinery and other modern appliances for the lifting of coffee, ete.

\section{SÃO PAULO COTTON}

In the course of these ehapters wages are frequently stated in Brazilian eurreney. It would be misleading to convert these into European equivalents, as the rate of exchange affects the cost of living of the agrieultural labourer only to a very small extent. These people live on nothing but the products of the soil in their immediate neighbourhood; their clothing is often made on the spot; their furniture is of the most simple kind, consisting frequently of a few boxes, bedstead or hammocks. In short, they are a self-eontained community. The rate of exchange does not affeet their eost of living or only very gradually, if at all, and eonsequently the wages remain more or less the same whether the rates of exchange are high or low. It is similarly the case with property, its value is only slowly affected by the exehanges. These remarks apply to the life up-country.

There is only one kind of cotton grown in São Paulo and this is the annual American Upland. Various types of this eotton are grown but they all belong to the one family. The average length of staple in São Paulo may be fairly assessed as being 28 to $30 \mathrm{~mm}$., i.e., one inch and slightly more. Soil eonditions vary eonsiderably, but generally speaking São Paulo is one of the most fertile areas in the whole of the world. Rain eonditions are satisfaetory and well suited to cotton growing with a defined interval of a dry season. The phenomenal yields obtained are a better guarantee of the suitable conditions than volumes of figures of rainfall and soil analysis.

The State of São Paulo has three distinct cotton zones, viz. :I.-Soroeabana, the oldest of the State, where cotton is supposed to have been eultivated for the last 150 years, but eertainly since the War of Seeession. This district is situated west of the eity of São Paulo.

II.-Central Zone, where the staple crop is coffee.

III,-North-Western Zone, to which Matto Grosso adjoins; this is only reeently being developed and has immense possibilities.

All the three zones were visited by us.

\section{SOROCABANA ZONE}

It was estimated that in 1920 the erop from this zone reached 200,000 arrobas of 15 kilos, but in 1921 it amounted only to about 150,000 arrobas.

Prineipally small eultivators grow eotton here and the methods of eultivation are very primitive. The soil is generally prepared in 


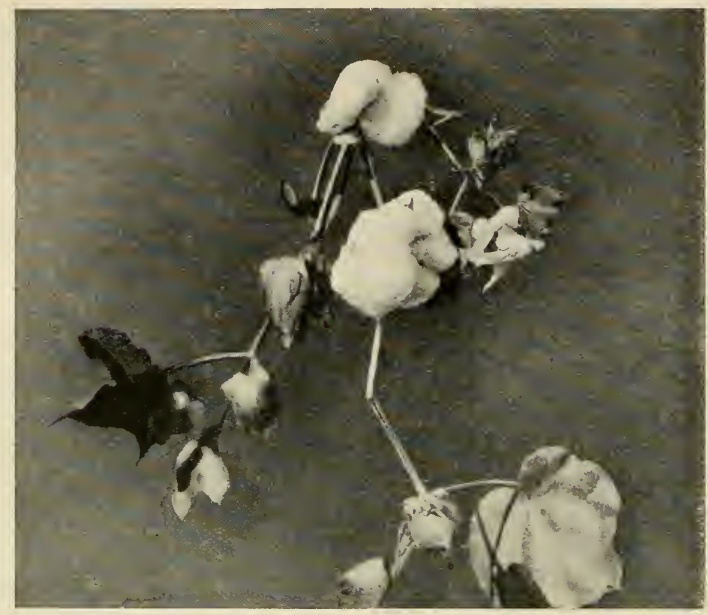

\section{American Cotton in São Paulo}

the following way. The brushwood, grass, etc., which grows to a huge height in a few years is burnt off, holes are chopped, as far as possible in a line, at a distance of about $1.20 \times \cdot 90 \mathrm{~m}$. Old tree stems and tree roots which were partly burnt off when the land was first brought under cultivation are scattered all over and take up considerable space. The soft wood rots away in a few years but the hard timber remains for many years before it decays. It pays only in rare instances to take it away. Latterly, in consequence of the high price of firewood which is sold here at $5 \$ 000$ per cubic metre (in the city of São Paulo at 10\$000), some old timber has been cleared away. In October-November a handful of seeds are placed in each hole, generally 3 to 4 seedlings are left standing. One, two or three hoeings are given during the growing period, according to the growth of the weeds. Picking begins end of April-beginning of May. Rotation of crops is not known, one and the same field will be used two and more years running for growing cotton and as there is plenty of vacant land the field is left fallow for a number of years. Of course in that time brushwood and grass grow to a great height and the culti. vator has to burn the field again before being able to grow crops, a system of natural manuring, no doubt.

In one instance, at CAMPo LARGO, we were shown a field that had grown cotton for 15 years consecutively and still the yield was $475 \mathrm{lbs}$. lint per acre. The average yield of the whole zone can safely be estimated at $450 \mathrm{lbs}$. but, probably it is considerably more.* In considering the yields it must be borne in mind that Indian corn.

*Compare this with India's average of $90 \mathrm{lbs}$.. U.S.A. with $220 \mathrm{lbs}$. and Egypt with 350 lbs. per acre. 


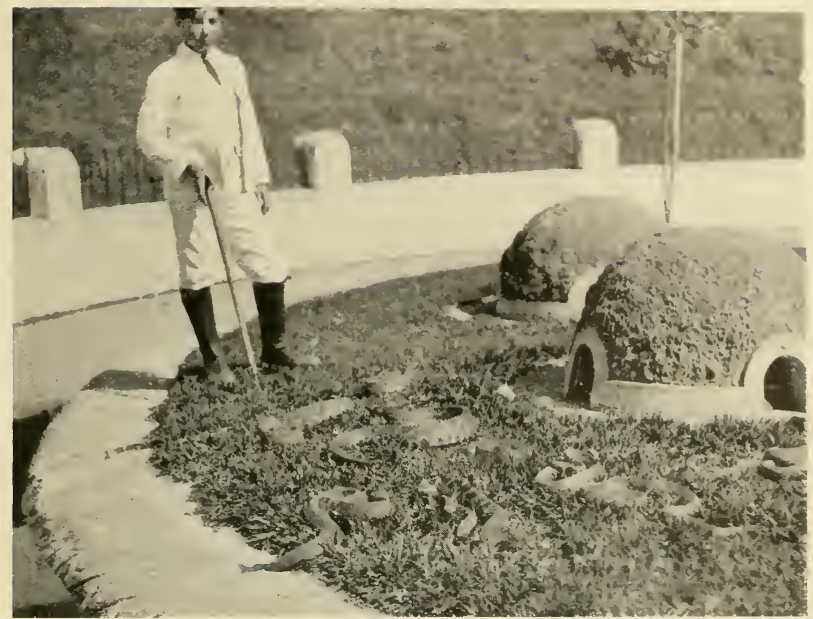

A Corner in the Snake Park at Butantan (São Paulo)

(Snakes from al! parts of the country are sent to Butantan; every month their poison is extracted for the preparation of a serum which has been proved to be an excellent remedy in case of poisoning by snakes)

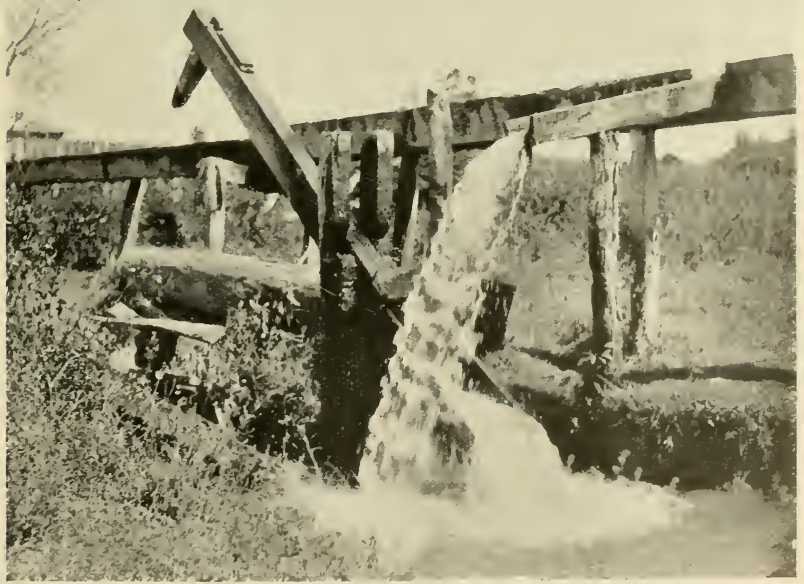

\section{Mill for grinding Indian Corn}

(The corn is placed in a hole in the tree trunk, into which the cone at the end of the beam fits. Through the filling and emptying of the water-trough at the other end the beam rises and falls and thus the cone crushes the corn. 
beans, etc., are grown simultaneously, that not only these crops but also the tree trunks, of which I have written, take up considerable room. Without these encumbrances the yield per acre would be considerably larger. There are also many rocks about in different places.

The small farmers hire a field for a year, paying 100 to 150 milreis rent per alqueire $(5 \cdot 6$ acres). A field labourer, if working by the day, is paid 3 to 4 milreis for work from sunrise to sunset.

Forty-five to sixty kilos seed cotton is the average weight a picker can gather in a day; the wages for picking are from 600 to 800 reis per arroba of 15 kilos.

In this zone there are also large landowners. We stayed at the estate of the "Companhia Agricola Industrial E Pastoril do Aterradinho," of which Mr. Clovis Camargo is the principal owner. He and his family own here about 14,000 " alqueires" land $=330$ square kilometres $=130$ square miles. Comparatively a small portion is under cultivation.

There has never been any plant selection practiced, nor has ever a plough been used. We interested Mr. Camargo in the various aspects of improved cultivation and have no doubt that he will introduce reforms.

On the estate are 425 families, each one looks after one " alqueire " ( $\leq 5.6$ acres) cotton, and plants up to one alqueire with Indian corn, beans, etc., for his own use. The agreement between the owner and tenant is that all the cotton must be sold to the company, which retains 1 milreis per 15 kilos seed cotton. This is all the company gains in lieu of rent. This zone is already approaching the central one and coffee is here cultivated as well. The Italians look after the coffee crop, but the Brazilian agriculturists, known here as " caboclos" take care of the cotton. The height of this distriet is about 500 metres.

On the estate is a saw ginning plant, a small oil and cake press, together with soap works. There is, of course, also the necessary machinery for handling the coffee beans.

Near ItAPETININGA, a town of 6,800 inhabitants, situated about 700 metres above sea level, small farmers are prevalent. The annual rent here was $150 \$ 000$ per " alqueire," the land changes the tenant every year, but the share system is also in use, the landowner lends the land and receives 25 per cent. of the produce. Round this district cotton is a very old crop. There are 11 ginneries in the town and four in the neighbourhood. The gimneries almost always buy the cotton, though sometimes they gin on commission. Of course, as everywhere, all the seeds of the various types are mixed in the ginnery. There was noticeable amongst the population a desire to progress and to use ploughs.

As a guide to the value of land I may mention that in the neighbourhood a piece of land, measuring 1,1:20 acres had been bought at the low sum of 50 contos (a conto $=1,000 \$ 000$ was at that time

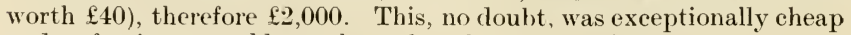
and a foreigner eould not have bought at that figure. 
The fibre of this district measured roughly an inch, it was irregular in staple and the picking was badly done.

We visited also farms called "CAPÃo ALto" and "Rossinha"; at the latter place cotton was grown for 12 years running.

The highest vields which I have ever known were on the estate of Mr. Manoel Guedes near Tatuhy, called "Pedlemeira" ; it is situated 680 metres above sea level. We inspected a good portion of the 180 "alqueires" under cotton; the average yield of these 1,000 acres was $500 \mathrm{lb}$. lint per acre, but some fields gave as much

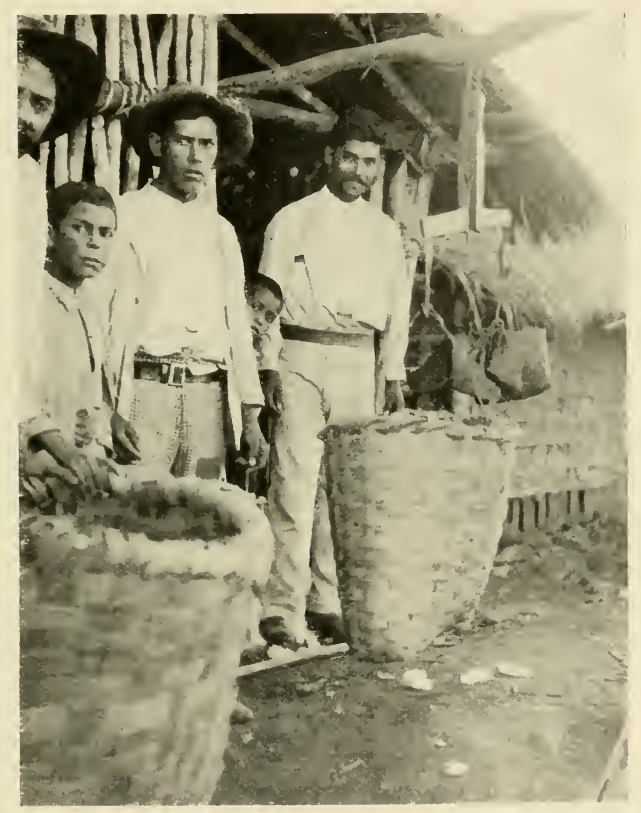

Weighing Cotton by means of Stones placed in a bag. Stone weights are used even in the advanced State of São Paulo

as 800 to $1,000 \mathrm{lb}$. lint per acre. The maximum yield in one year of one plot of land, slightly short of an "alqueire" $(5 \cdot 6$ acres) was: $14,619 \mathrm{lb}$. Seed Cotton (which works out to about $890 \mathrm{lb}$. lint per acre), 2,000 litres Beans and 2,000 litres Indian Corn. Such almost phenomenal yields are not to be met with anywhere and a photograph hardly conveys the impression one gets. A cotton field rarely comes out well in a photograph, the mass of white often lacks the contrast to bring it up. The following photographs give only a slight impression of the overwhelming weight of cotton we saw. 
Mr. Guedes has the following arrangement with his tenants who all work on the share system. The cotton must be sold to him, the first year after clearing the forest he keeps 20 per cent., the second 15 per cent., third year $12 \frac{1}{2}$ per cent. and after that 10 per cent. Besides this profit, the estate receives 40 per cent. of all the cereals grown, such as Indian corn, rice, and beans are also counted as cereals.

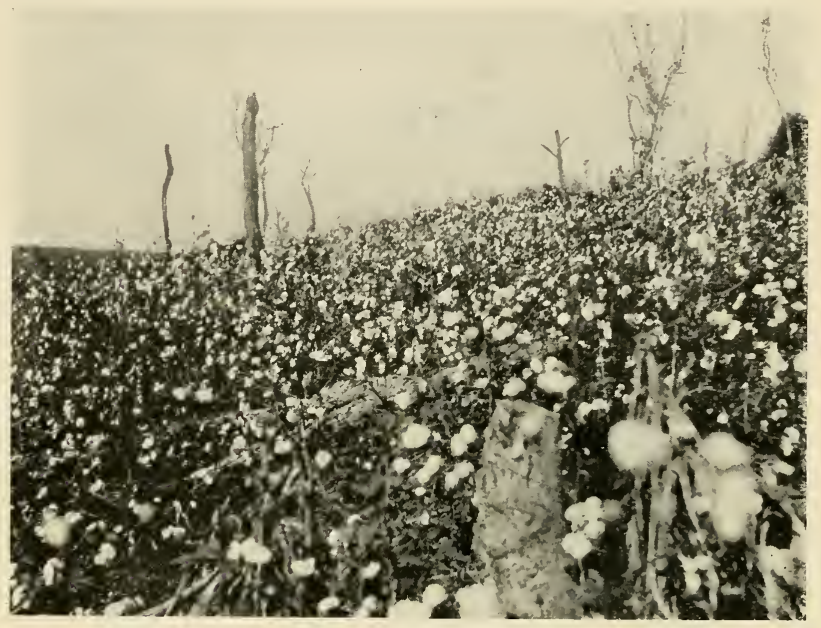

One of Mr. Guedes' cotton fields near Tatuhy* (American cotton)

Cotton is grown for at least 3 years consecutively, after that Indian corn is planted for a year, then cotton again. There are lands on the "fazenda" (farm) which have been used 12 consecutive vears for cotton.

36 tenants' families live on the estate and about 60 in the town of Tatuhy which is about $2 \frac{1}{2}$ miles distant. Each family looks after 12 to 24 acres.

Very little damage had been done by the pink boll-worm, as the seed had been exposed to the heat of the sun before planting. The cotton worm had eaten most of the leaves, as is noticeable in the photograph, as however early planting had been resorted to, and only early maturing varieties had been selected, the bolls had been formed before the worm had attaeked the leaves and little or no damage was done to the bolls.

When land has been cleared of the forest, it is best to grow first Indian corn for a few years, before cultivating cotton on it. At times Indian corn and beans are grown in the same field with cotton. A good cultivator will clear the land three times a season of weed. On this "fazenda" cotton shrubs are stopped (i.e., tops eut off) after three months growth, otherwise they would shoot up too mueh.

* The frontispiece to the book shows also one of Mr. Guedes' fields. 
The cost of land in this very fertile district is from 400 to 500 milreis per alqueire $(5 \cdot 6$ acres $)$. For clearing the timber, burning down the brushwood (but leaving the hard wood standing), $120 \$ 000$ per alqueire are charged. As latterly timber of first-class quality has been in good demand, it has paid to get the hard wood removed. In this part of the country there are for instance "peroba" trees which sell at 70 to 80 milreis per cubic metre and generally the wood obtained out of the forest has more than paid for the cost of clearing.

The fibres on this "fazenda" averaged about an inch $(28 \mathrm{~mm}$.), they were very strong, but the cotton was not well picked, a lot of foreign matter being gathered with the cotton. Some fields had cotton of $30 \mathrm{~mm}$, and even more.

There is no plant or seed selection carried on; if this were resorted to excellent results could be obtained on this otherwise well managed estate.

In the year 1918 when the crop was especially good and prices were ruling high, a tenant made on one " alqueire " cotton (5.6 acres) a profit of 3 contos $(3,000 \$ 000)$ and the estate 1 conto.

On the Pederneira estate are also 100,000 coffee trees, looked after by an Italian colony.

Mr. Guedes has several other estates in the neighbourhood, one of which, "Victoria," includes a water fall which produces at present 2,000 h.p., but is capable of extension to 20,000 h.p. This hydroelectric plant drives a cotton mill of Mr. Guedes at Tatuhy, and supplies light to five towns and villages. In $1912 \mathrm{Mr}$. Guedes was fortmnate enough to be able to buy this estate of 886 alqueires at the low price of 110 contos.

Mr. Guedes is a typical Paulista, always planning and scheming how to improve his many undertakings.

At another farm in this district the landowner paid Italian settlers $500 \$ 000$ per "alqueire" to cultivate cotton for him. This contract price includes all the work from the preparation of the soil until the cotton was ripe for picking. The latter had to be paid extra at the rate of $1 \$ 000$ per 15 kilos. His average crop was $3901 \mathrm{~b}$. per acre, but as he said, he did not bother about his cotton, his principal occupation being stock-raising.

As a further proof of the fertility of the soil I may mention that six weeks after planting alfalfa (a kind of clover) the first cutting was made. The alfalfa was planted on the 19 th December : at the beginning of May five cuttings had been taken off and the farmer expected to be able to get twelve cuttings in the year. We often heard of seven, eight and nine cuttings, which is phenomenal in comparison with the U.S.A. The land which produced these crops was bought in 1920 at $150 \$ 000$ per "alqueire" and it was recently sold again at $500 \$ 000$ per "alqueire."

We walked here through some pasture land which had a coarse grass on it, five feet in height, the blades being covered with an oily substance. It was what is called here "Catingueira" grass, an excellent fodder for fattening cattle.

There is plenty of available land for the extension of cotton growing in these parts. 


\section{No. II. CENTRAL ZONE.}

During our journey through these parts we had the advantage of the eompany of Mr. Raphate Sampaio VIDAL, one of the Deputies of the State, who has a thorough knowledge of the country and the people.

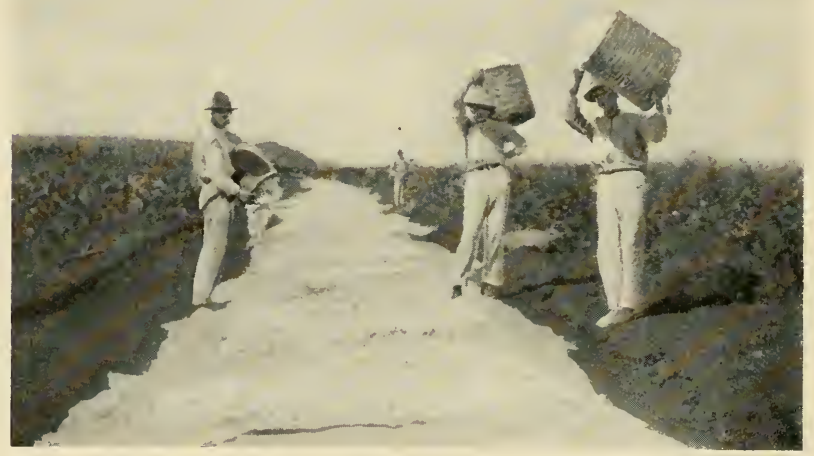

Cotton Pickers at Villa Americana delivering cotton at side of field. Each picker has his special pile of cotton

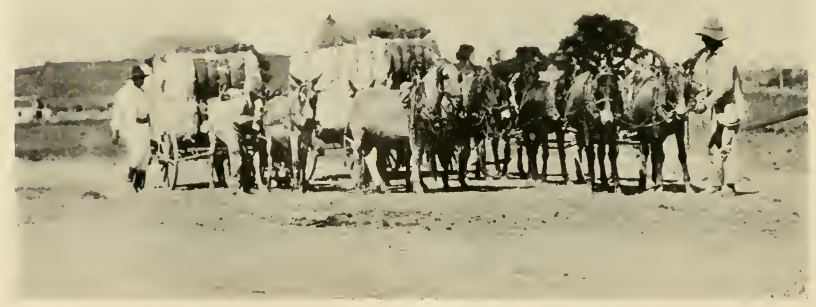

Transportation of Cotton at Villa Americana, São Paulo 


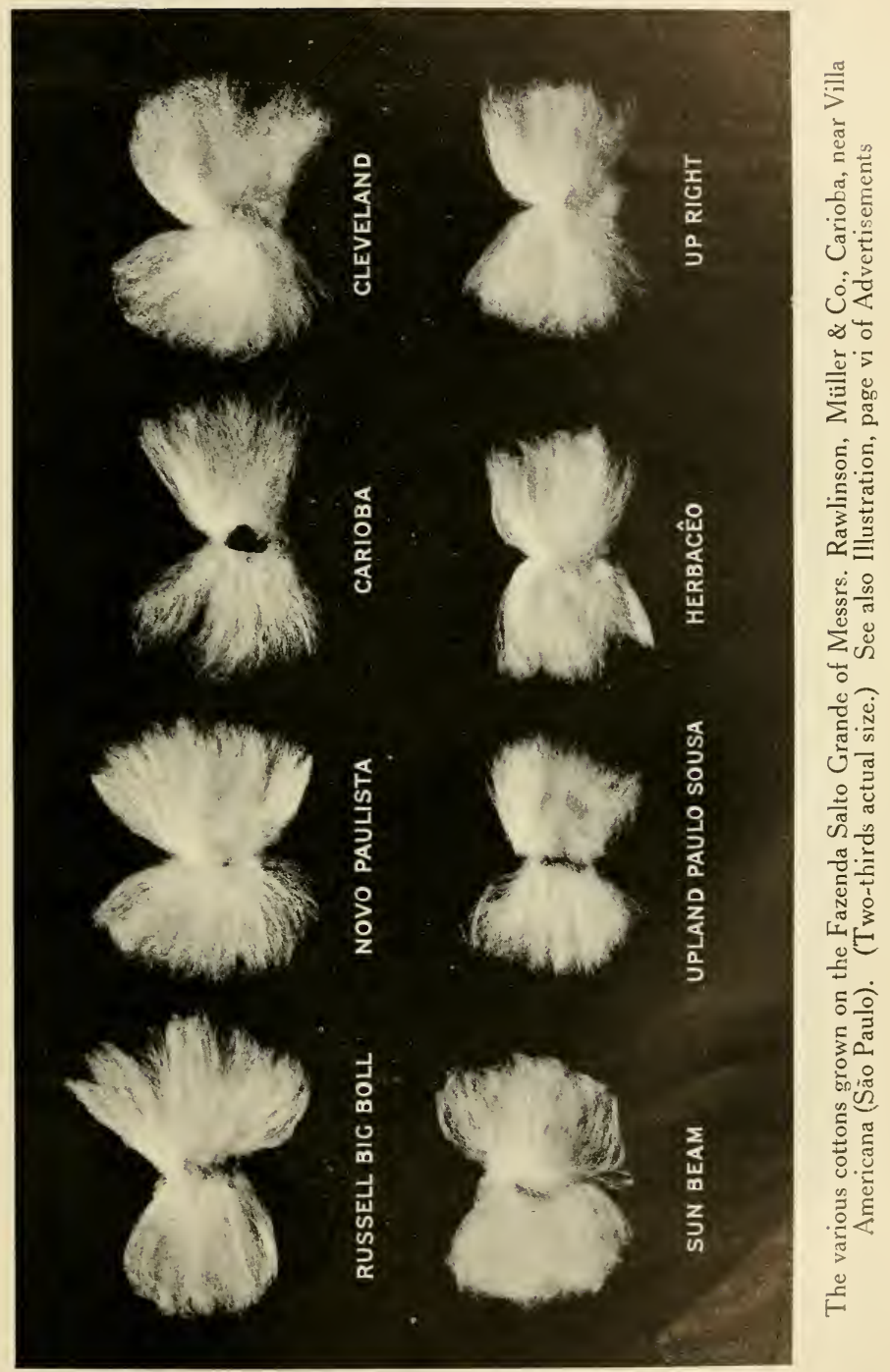


Our first visit was to Villa Americana where we inspected the "Fazenda Salto Grande" belonging to Messrs. Rawlinson, Müller \& Co., of Carioba.

The management of this plantation is in the very capable hands of an Italian, Mr. F. Fornazaro, who knows his work and maintains excellent discipline.

The extent of the "fazenda" is 1,100 alqueires $(6,160$ acres) 1,500 of which are under cultivation. It was bought by the present owners in 1907 , principally as it included a waterfall which they have utilised for driving their cotton mill at Carioba. The purchase price was then only 170 contos; 1,700 h.p. are generated by the fall, but there is energy for another 1,200 h.p. ; the cost of the hydro-electric plant was 300 contos. Current is supplied for the driving of the mill and the lighting of several towns and villages.

The property is situated at an altitude of about 450 meters.

Of the 1,500 acres under cultivation half are given up to cotton; various American kinds, such as "Russell Big Boll," "Sunbeam," etc., are grown. The manager has created various crosses, one especially, called "Carioba," is between "Webber" and "Russell Big Boll," and has turned out so well that thry can use it at the mill of $\mathrm{Mr}$. H. Th. Müller for spinning high counts up to $60^{\circ} \mathrm{s}$. It has $1 \frac{3}{16} \mathrm{in}$. staple; its yield is $600 \mathrm{lbs}$. lint per acre. The average yield of the whole plantation works out to 3601 s. per acre.

This is the first and only plantation which we visited in Brazil where real scientific plant selection, and even an attempt at scientific seed breeding was made; others have the intention of doing the same work, but here it is actually done by a practical farmer. Russell Big Boll has been increased in length by several millimetres through plant selection. "Novo Paulista," another cross of the manager, measures fully $30 \mathrm{~mm}$. and is very silky and strong. Care is being taken to prevent cross fertilisation by kceping the fields of the different kinds sufficiently far apart and in the ginning strict supervision is kept that no mixing takes place.

Rotation of crops is adhered to ; generally Indian corn, then cotton and three years' sugar cane are grown. (Sugar cane as a rotation crop with cotton is not used in other countries.)

When the cotton is being picked cotton sheets are spread out at the side of the field; each sheet is numbered and each picker has to deposit his cotton on the special sheet corresponding to his own number. If anyone does not pick clean the foreman can at once trace who is picking carelessly, in which case a reduction in the picking wage is made. (See illustration, p. 78.)

On the estate are sixty families, each of which has three hectares; they work on the share system, keeping the proceeds of two-thirds for themselves and one-third goes to the company. The tenant is debited with two-thirds of the cost of manure: money is advanced for implements, manure, etc. The tenants must conform to the instructions of the manager as regards the cultivation of the plot. The manager has further the call on the tenant when he requires labourers for the land of the company, where he raises special cottons : 


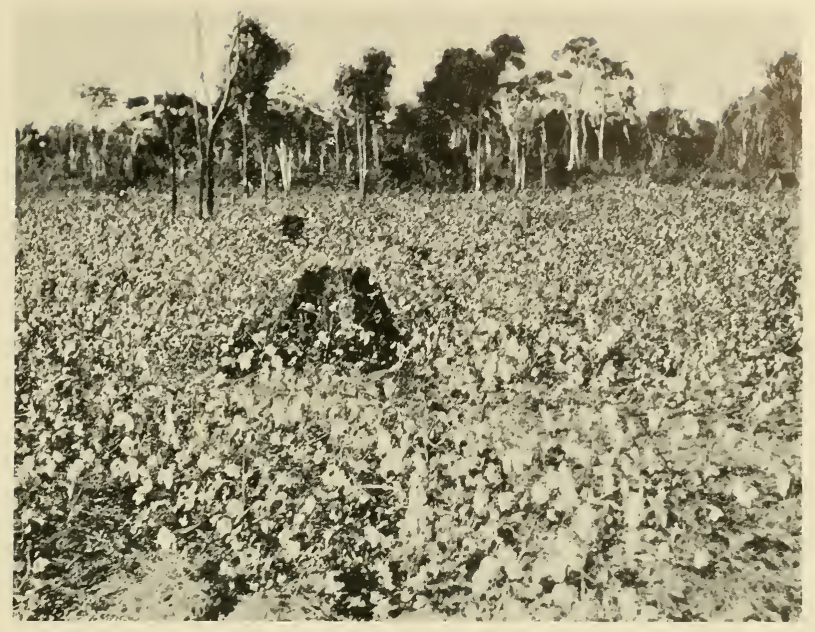

Cotton Field on the Fazenda "Salto Grande" of Rawlinson, Müller \& Co., Carioba, Villa Americana

for this work they get paid a daily wage. A man able to work the disc-cultivator gets 5 milreis per day.

The company has some $£ 3,000$ invested in ploughs and other agricultural machinery. Practically all the cotton raised on the estate is used in the mill of the company, where 18's is the average count, though exceptionally up to 60 's has been spun from cotton raised on the estate. The cotton is, of course, by far too good for such low counts as 18 's.

Planting takes place middle of November, and as only early maturing kinds of cotton are used picking begins about middle of April. This part of the country gets sometimes frost in June.

The manager told me that if the price of seed cotton is $7 \$ 000$ per 15 kilos it pays as well as any crop.

This plantation shows what can be done throughout São Paulo, the land does not seem as fertile as the Sorocabana or the north-western zone.

The rent paid in adjoining parts is 200 milreis per "alqueire." The present purchase price of land was stated to be one conto per alqueire, but no doubt when buying a large estate considerable reductions can be obtained.

Our next visit was to São Carlos, 800 metres high, and then to Sampaio Vidal, named after the family of the "Diputado" who accompanied us. The soil here begins to be of that fertile red earth, known as "terra roxa," excellent for coffee cultivation; it looks almost like finely ground coffee; it produces a dust which penetrates through everything, even to the works of the watch. 
The manager at this plantation had only recently taken up cotton cultivation. There were 50 " alqueires " under cotton, Russell Big Boll. The field was not as clear of other kinds, and afterwards at the ginnery we could see that about 20 per cent. of the seed was of a different type, being almost naked, whilst Big Boll is a covered seed. This of course, accounted for the lack of uniformity of fibre.

There are on the plantation 400,000 coffee trees which seemed in good condition, the branches being heavily laden with the coffeecherries. The ground underneath the trees was kept clear of weeds.

Adjoining the coffee estate is another farm of 200 hectares, part of which is "terra roxa" soil, where cotton is grown by a small colony of tenants. Mr. Sampaio Vidal had the idea of selling this land for a cotton seed farm. This farm is 550 metres above sea level.

We spent a few days on the Coffee Fazenda "SAnta Gertrudes," belonging to Count Prates, not very far from the last place.

When a few years ago (1918) a severe frost damaged a large portion of the coffee plantations, most trees were cut down, killing many and withering the rest up to the roots, the coffee planters having sufficient space between the rows of their coffee trees, planted a good deal of cotton. The coffee trees have recovered and the young trees grown up, consequently there is now not sufficient space for growing cotton everywhere. In young plantations however, there is sufficient room and some planters continue to grow cotton even in the crowded spaces along the rows of fully developed coffee trees.

Count Prates was very satisfied with the cotton his tenants grew for him. There are altogether over 900,000 coffee trees on this estate; the value of each is placed as between 2 to 3 milreis.

Cotton is planted between some of the rows of coffee trees, amongst others Indian corn and beans, the latter the staple food of the Brazilians.

Cotton cultivation by the big coffee planters is undertaken on many estates. Latterly, however, the low price of cotton has been a cause for the reduction of cotton acreage. The lack of proper seed distribution is responsible for the absence of uniformity of fibre, the cotton raised is about an inch in length and quite serviceable, but generally not sufficient care is taken in the picking. About 10 per cent. of the seed in the ginnery of Conde Prates was a different kind from the main crop, viz., Russell Big Boll. No plant selection is being undertaken.

In this part of the state is situated the "Instituto AGronomico" of Campinas, the director of which is a Frenchman, Dr. J. J. Arthaud Berthet; his agricultural manager is a German, a Mr. Hermann, and it deserves to be said to their credit that both have been able to work together right through the war.

This is a scientific institute, probably the only one, where on behalf of the Government, cotton plant selection and breeding has so far been carried on. No doubt the new Government cotton farms of the Cotton Department will carry on similar work in the future in all parts of the country. 
The Institute has 314 hectares under cultivation, the greater part being used for coffee, but quite a large area of land is devoted to cotton. There were four varieties out of a great number which attracted my attention, particulars of which are:

Gining Outturn

\begin{tabular}{|c|c|c|c|c|}
\hline Durango & . & $\begin{array}{l}\text { Yield : } 2,050 \text { kilos per hectare } \\
\text { Length of fibre }: 27 \cdot 1 \mathrm{~mm} \text {. }\end{array}$ & $\cdots$ & 29 per cent. \\
\hline Russell Big Boll & $\cdots$ & $\begin{array}{l}\text { Yield : } 1,641 \text { kilos } \\
\text { Length : } 29 \cdot 4 \mathrm{~mm} .\end{array}$ & . & $32 \cdot 3$ per cent. \\
\hline Sea Island B. & . & $\begin{array}{l}\text { Yield : } 3,030 \text { kilos } \\
\text { Length : } 31 \cdot 7 \mathrm{~mm} .\end{array}$ & . & $31 \cdot 4$ per cent. \\
\hline $\begin{array}{l}\text { Cerman X. } \\
\text { ampo Brito. }\end{array}$ & & $\begin{array}{l}\text { Yield not yet obtainable. } \\
\text { Length : about } 30 \mathrm{~mm} \text {. }\end{array}$ & & \\
\hline
\end{tabular}

The names given are misleading, as they have nothing to do with California or the Sea Island district.

Altogether 40 varieties were grown, one hectare of each. These are too many and moreover no protection was given against eross fertilisation. I pointed this out and the Director undertook to remedy this defect. There is plenty of land available and other crops than cotton can be grown between these experimental plots.-It would also be well to have check-plots in different parts of the estate.

At Piracicaba not very far from Campinas is the Agricultural School "Luiz de Queiroz," situated in a beautiful park, towards the upkeep of which the São Paulo Government pays annually 370 contos and the Federal Government 30 contos.

The attendance this year is 110 students; all reside in the town of Piracicaba. There are 15 professors on the teaching staff; each has his own magnificent laboratory. The school is extremely well fitted up with the latest appliances and the ehemical laboratories are probably not excelled by those of the Universities of Europe.

Although this school is situated in a cotton centre, no apparatus for measuring the length of fibre, resistance, etc. (such as we found even in Mr. Street's mill in São Paulo), were provided. Indeed litt'e attention seems to be paicl to cotton.

The school has 309 hectares of ground, 78 of which are cultivated and of the latter only 8 are under cotton. No seed selection has been made nor even plant selection and one of the professors told me that it was not intended to grow cotton at all in the coming season. The yicld of the cotton plots was above the average and the cotton looked well though the length of the cotton was lacking in uniformity. Even here the cotton picked was very dirty and stalks were present in large quantities.

It is to be hoped that the authorities will insist upon greater attention being given to cotton in this excellently fitted-up school. The students are generally sons of landowners and if they cannot get an opportunity of learning plant selection and sced brecding in an institute of this kind, it is hardly to be expected that they will learn it in any other way. 


\section{No. III. NORTH-WESTERN ZONE}

Of this cotton zone a typical sample, Biriguy, was selected for our inspection. The railway journey takes one through Bauru, the terminus of the Sorocabana Railway. This is a sandy place of recent origin, where until 12 years ago very few houses existed; now it is a town of some 6,000 inhabitants, principally engaged in railway work, as three different companies have made Baurú their terminus. After 12 hours' railway journey through enormous virgin forests one reaches Biriguy. The vast immensity of the forests leaves a great impression on the mind of the traveller during this journey. What one sees is, of course, only a sample of the seemingly endless forests which are gradually being brought under cultivation, providing firstclass cotton land. These forests are beautiful on account of the great diversity of trees. Huge trees, some covered with masses of pink or yellow flowers which contrast magnificently with the blue sky, are very numerous.

Our main object in visiting Biriguy was to become acquainted with the work of colonization undertaken by the "Companhia de Terras, Madeiras e Colonisação de São Paulo," whose technical manager is Mr. Robert Clark, a Scotchman who has been many years in the interior of Brazil.

The climate is excellent; not too hot, though during the day a few hours are hot, the atmosphere is dry, and the nights are cool throughout the year. There is sufficient rainfall for cotton and this in well-defined periods.

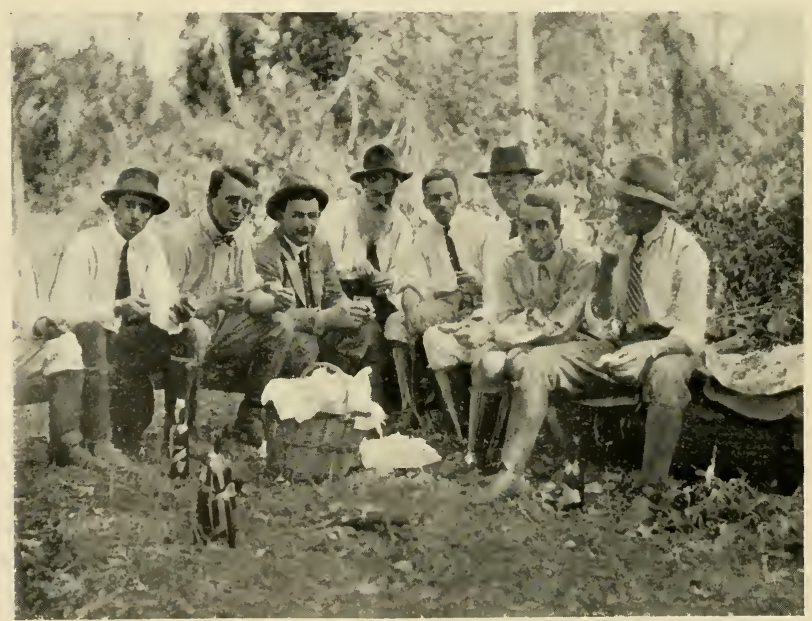

The Cotton Mission at Luncheon in the Biriguy Forest 


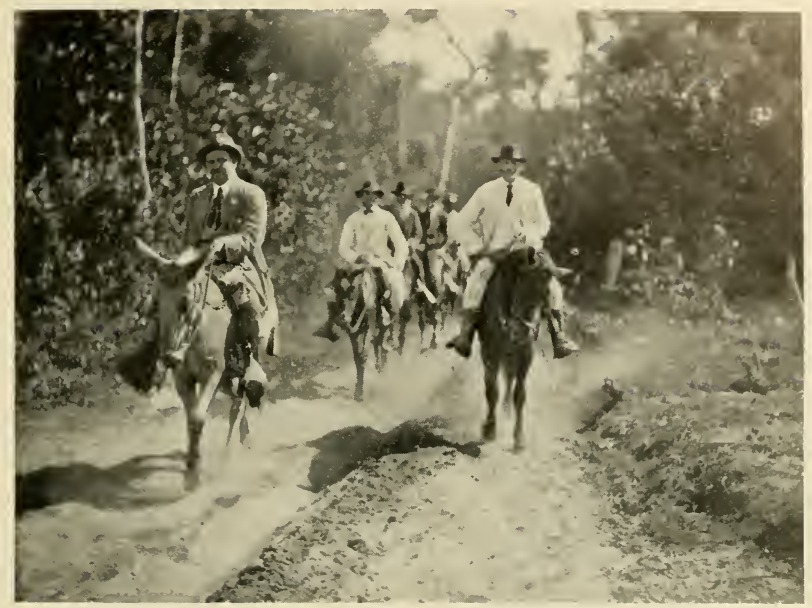

The Mission riding over the Estate of the Biriguy Colonization Company

The Company acquired first some 19,000 "alqueires" but as the land was taken up by settlers, they bought an additional area with the profits. So far, 32,000 "alqueires" (179,200 acres) have been sold and these are under cultivation; the Company has a similar area, in forest land, practically all rich soil. on a high level. Land is sold in lots of from 5 to 100 "alqueires" (1 "alqueire" $=5 \cdot 6$ acres) the average holding being 15 "alqueires" or 84 acres.

At the time of our visit 1,763 lots had been sold, but as some families have two and three lots one can say that about 1,700 families have settled on the land since 1912 when the Company started operations. So far, all profits have been used for extension purposes and no dividend has been paid.

The general rule is for the new-comer to pay 30 per cent. of the purchase price of the land in cash and the remainder he pays out of his profits. Practically all have been able to do this within three years.

The land belongs to the settler from the day of the first payment. The Company has no right to dictate as to what crops are to be grown or to whom the produce has to be sold. The colonists are entirely free agents.

As everywhere in São Paulo, one meets here too a cosmopolitan crowd ; the composition of the colonists as to nationality is as follows :

$$
\begin{aligned}
& 40 \text { per cent. .. } \quad . . \quad \text {.. } \quad \text {.. Italians. }
\end{aligned}
$$

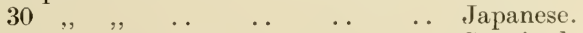

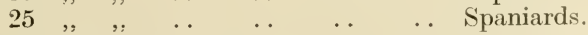

The rest consists of Germans ( 3 families), Poles, Austrians, French, American, Portuguese and one Brazilian. 
The average prices at which land has bcen sold are :

$\begin{array}{cccccc}1913-1917 & \ldots & \ldots & \ldots & \ldots & 100 \$ 000 \text { per alq. }(5 \cdot 6 \text { acres }) . \\ 1918 & \ldots & \ldots & \ldots & \ldots & 150 \$ 000,,,, \\ 1919 & \ldots & \ldots & \ldots & \ldots & 200 \$ 000,,,, \\ 1920 & \ldots & \ldots & \ldots & \ldots & 250 \$ 000 \quad,,,,\end{array}$

Out of the 1,700 families, only one has given up possession of the land-got the money returned and left. Three other families have left the district, but have let the land to their friends. This is a good sign and speaks well for the management and the fertility of the land. There has not been a single dispute about ownership of land.

Land ownership in Brazil is a difficult point; the original titles are made out on the basis of maps, boundaries, etc., but these maps have proved often to be wrong. The country has not yet been thoroughly surveyed and we have found mountain ranges 30 miles from the place indicated by the maps. The courses of rivers are also frequently not properly marked on the maps.

Though this colonization company may charge comparatively high prices for the land, yet the buyers have security of title and other advantages such as roads, an established community, etc., which are worth a good deal.

There are now on the estate 700 kilometres of cart-roads, few of them fit for a motor, but efforts are being made to improve them.

Whilst the Japanese in other parts of São Paulo-working as tenants-are not considered satisfactory labourers, yet as proprietors of land on this estate they give every satisfaction. The Japanese colonists are all concentrated in one part of the estate.

The crops grown by the people are coffee, cotton, Indian corn, beans, etc. The land is only 400 metres above sea-level and for this reason agriculturists consider coffee a risky crop as frost is more likely to attack low-lying ground. 600 metres is considered the safe line. In 1918 all the coffee trees in this district were cut back by the frost (the same as in most districts in the south) but the manager had the trunks of the trees eut down under the soil and the old trees grew up again very vigorously ; these trees, after two years and eight months now yield heavily. The Company has a coffee plantation of its own, called "Agua Branca" of 1,055 "alqueires"; the colonists looking after this are paid at 130 milreis per year for every 1,000 trees and 600 reis for gathering 50 litres of the berries; the colonists working this coffee plantation are allowed to plant, on their own account, Indian corn and beans between the trees. For additional day labourers they have to pay $4 \$ 500$ per day, if he is a colonist on the estate, and if he is an outsider 5 milreis, plus food $(=2$ milreis $)$. This is very high in comparison with the rest of the State but everything is dear here. On the "Cafezal " there are 300,000 trees and this year they hope to increase the number to 400,000 . The crop is earlier here than in the south and was being gathered at the time of our visit, early May. 200,000 trees, two vears and eight months old, had produced 25,000 "arrobas" of 15 kilos. Coffee yields here 125 " arrobas" per 1,000 trees, which is 25 per cent. higher than the best in the south. On the fazenda of the company they had an exceptional cotton crop in 1919 
6 "alqueires" gave $800 \mathrm{lbs}$. lint per acre. These yields are on coffee ground where the coffee plants are small and there is therefore room for cotton between the rows of coffee trees; the yields would therefore be much larger had the whole field been given up to cotton. Mr. Clark, the managing director, considers that over his whole estate the cotton crop is 250 arrobas $=500 \mathrm{lbs}$. lint per acre, where cotton is grown as a "catch-crop," being of secondary importance to coffee and Indian corn. In some fields we saw cotton, corn, beans and coffee all growing mixed together. It must be remembered that India gives as on an average not a $100 \mathrm{lbs}$; the U.S.A. 220lbs. (when an acre in the Mississippi exceptionally yields 500lbs. lint it is a very rare occasion). Egypt's yield has gone down to 350lbs. ; in 1920-21 it will not be more than $270 \mathrm{lbs}$. In the latter two countries much more labour is bestowed on the cultivation than in São Paulo and cotton occupies the field alone.

The cost of clearing the land, burning down forests, and getting it ready for cultivation is here estimated to be 200 milreis per "alqueire"; this work is generally carried out by natives from the State of Bahia who have specialised in it for many years.

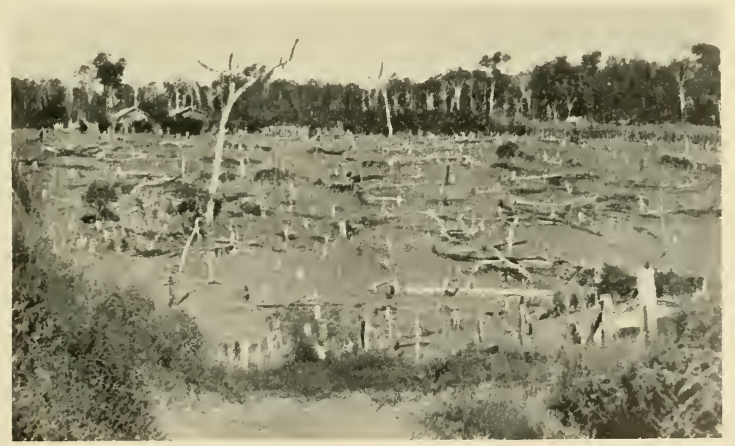

The Clearing of the Forests at Biriguy

The settlers build their own houses, using the wood of the trees they have felled; there is a saw-mill at the station. Some use nothing but bamboo and clay. The cost of a small dwelling of a primitive kind is 700 milreis. (See illustration, p. 88.)

The method of cultivation is a rough-and-ready one as described in the early part of this chapter.

There were two ginneries working at Biriguy and shortly the number will be increased to four. The charge for ginning and baling was high, namely, $3 \$ 200$ reis per 15 kilos. The bale press was a primitive screw press (see $p$. 101). The cotton varied in length, even in one field. It would be a great advantage if a uniform supply of 


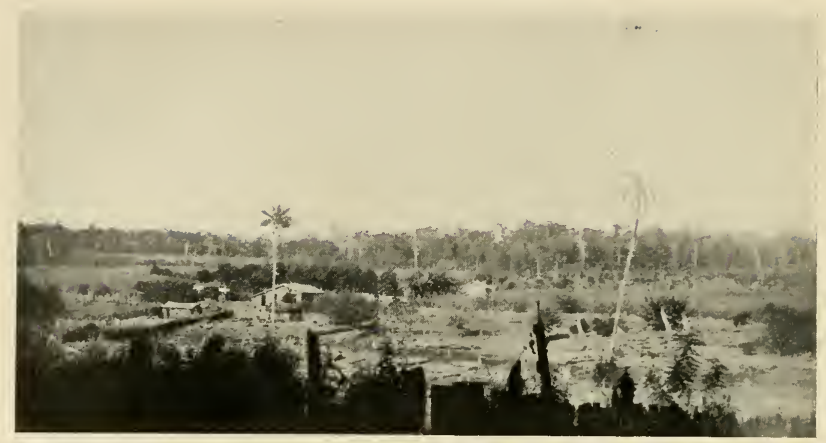

Biriguy. The Settlers' Abode

cotton seed of one variety were delivered by the Government to the manager for distribution. This would undoubtedly lead to the improvement of the staple.

The Company does not buy the produce of the settlers. They sell to small merchants and these again sell to larger merchants in the city.

The railway freight of coffee and cotton from this place to Santos is very high indeed. The freights are a severe handicap and were it not for the enormous fertility of the soil the new settlers would not be able to compete.

The Fazenda Aracatuba, situated in the municipality of São José do Rio Preto, along the River Tiete and the North-Western Railway, comprising 46,371 alqueires (each of $24,000 \mathrm{sq}$. metres which is equivalent to $3,000,000$ English acres) is another estate which, from information given to me by the owner, Mr. Paes Barretos, seems of similar fertility as the district of Biriguy, just described. A large portion of the estate is still virgin forest and the soil and climate are considered to be favourable for coffee and cotton. The owner claims the additional advantage that besides the railway, he has got river communication with the Argentine Republic. The distance by rail from the estate to São Paulo is $812 \mathrm{~km}$., to Santos, $991 \mathrm{~km}$. and to Rio de Janeiro, 1,301km.

Hydraulic Bale Press.-The largest hydraulic cotton bale press in existence in Brazil is in the city of São Paulo, belonging to Messrs. L. G. de Sousa Pinto \& Co., 13, Rua Alvares Penteado. The press is of German make and can give a maximum pressure of 1,014 kilos per cubic metre. The Chief of the Cotton Department states that São Paulo cotton can stand a pressure of 720 kilos per cubic metre. The bales are of 300 kilos weight and instead of iron hoops, wire is used. milreis.

Every ginning machine in São Paulo pays an annual tax of 500 


\section{COFFEE.}

One cannot speak of São Paulo without mentioning in some detail its greatest staple erop, coffee. This State as regards the world's supply of coffee takes up a more prominent position than the U.S.A. as regards cotton, as will be readily recognised from a perusal of the following statistics.

The production of eoffee in São Paulo has been as follows :

$\begin{array}{ccccc}1909 / 10 & 1910 / 11 & 1911 / 12 & 1912 / 13 & 1913 / 14 \\ 12,124,051 & 9,458,376 & 10,580,172 & 9,470,833 & 11,072,387 \\ 1914 / 15 & 1915 / 16 & 1916 / 17 & 1917 / 18 & 1918 / 19 \\ 9,206,507 & 11,711,200 & 9,937,895 & 12,210,150 & 7,253,250\end{array}$

sacks of 60 kilos whilst the production of the world is shown in the following table :-

WORLD'S PRODUCTION OF COFFEE FOR THE LAST 20 YEARS (IN SACKS OF 60 KILOS)

\begin{tabular}{c|c|c|c}
\hline SEASON & BRAZIL & OTHER SOURCES & TOTAL \\
\hline $1899-1900$ & $9,959,000$ & $4,832,000$ & $13,801,000$ \\
$1900-1901$ & $10,927,000$ & $4,173,000$ & $15,100,000$ \\
$1901-1902$ & $15,439,000$ & $4,296,000$ & $19,735,000$ \\
$1902-1903$ & $12,324,000$ & $4,340,000$ & $16,664,000$ \\
$1903-1904$ & $10,408,000$ & $5,575,000$ & $15,983,000$ \\
$1904-1905$ & $9,968,000$ & $4,480,000$ & $14,448,000$ \\
$1905-1906$ & $10,227,000$ & $4,565,000$ & $14,792,000$ \\
$1906-1907$ & $19,654,000$ & $4,160,000$ & $23,814,000$ \\
$1907-1908$ & $10,283,000$ & $4,551,000$ & $14,834,000$ \\
$1908-1909$ & $12,419,000$ & $4,999,000$ & $16,918,000$ \\
$1909-1910$ & $14,944,000$ & $4,181,000$ & $19,125,000$ \\
$1910-1911$ & $10,548,000$ & $3,976,000$ & $14,524,000$ \\
$1911-1912$ & $12,491,000$ & $4,918,000$ & $17,409,000$ \\
$1912-1913$ & $11,458,000$ & $4,915,000$ & $16,373,000$ \\
$1913-1911$ & $13,816,000$ & $5,796,000$ & $19,612,000$ \\
$1914-1915$ & $12,867,000$ & $5,019,000$ & $17,886,000$ \\
$1915-1916$ & $14,992,000$ & $4,764,000$ & $19,756,000$ \\
$1916-1917$ & $12,112,000$ & $4,579,000$ & $16,691,000$ \\
$1917-1918$ & $15,127,000$ & $3,720,000$ & $18,847,000$ \\
$1918-1919$ & $9,140,000$ & $4,500,000$ & $14,640,000$ \\
$1919-1920$ & $9,400,000$ & $4,600,000$ & $14,000,000$ \\
$1920-1921$ & $11,300,000$ & $4,800,000$ & $16,000,000$ \\
\hline
\end{tabular}

The coffee consumption of the world reached its highest figure in $1914 / 15$ with $21,378,646$ sacks of 60 kilos; in $1916 / 17$ it was estimated at $14,600,000$ sacks and during the last few years the consumption is stated to be IS millions, but I doubt whether these consumption figures are reliable.

The following remarks, taken from the Trade Report, April, 1921, of the London \& Brazilian Bank Ltd., show the importance of coffee as an export crop to the country.

"During the twelve montlis ended 31st December, 1920, the total value of coffee exported from Brazil amounted to approximately 50 per cent. of the total value of Brazil's exports for the year, which demonstrates that this product still continues to constitute the axle of Brazil's wealth and export trade. The following eomparison of the 
currency values of the total exports from the country and those of coffee alone, since 1916, may prove of interest :-

\begin{tabular}{|c|c|c|c|c|c|c|}
\hline & & $\begin{array}{c}1916 \\
\text { contos }\end{array}$ & $\begin{array}{c}1917 \\
\text { CONTos }\end{array}$ & $\begin{array}{c}1918 \\
\text { contos }\end{array}$ & $\begin{array}{c}1919 \\
\text { CONTOS }\end{array}$ & $\begin{array}{c}1920 \\
\text { contos }\end{array}$ \\
\hline Total exports & .. & $1,137,000$ & $1,192,000$ & $1,137.000$ & $2,179,000$ & $1,752,000$ \\
\hline Coffee only & .. & 589,000 & 440,000 & 353.000 & $1,226,000$ & 861,000 \\
\hline
\end{tabular}

Owing to the lower quotations that ruled during the year 1920, as compared with those of the preceding year, the total value of coffee exported decreased much more than the quantity shipped, as the subjoined table shows:-

\begin{tabular}{|c|c|c|c|c|}
\hline & & & $\begin{array}{c}\text { SHIPMENTS } \\
\text { BAQS }\end{array}$ & VALUE \\
\hline 1916 & . & .. & $13,039,000$ & $£ 29,281.000$ \\
\hline 1917 & .. & .. & $10,606,000$ & $23,054,000$ \\
\hline 1918 & .. & . . & $7,433,000$ & $19,0+1,000$ \\
\hline 1919 & . & . & $12,963,000$ & $72,607,000$ \\
\hline 1920 & .. & .. & $11,523,000$ & $52,817,000 "$ \\
\hline
\end{tabular}

In the heart of the S. Paulo state, as far as the eye reaches, one sees the undulated country carefully planted with straight rows of coffee trees, of which 834 millions are said to exist in this State. Each tree gives an average production (over 10 years) of 49 arrobas at 15 kilos per 1,000 trees. The yield has fallen steadily from 250 arrobas and Mr. Cincinato Braga states that in 10 years' time-unless chemical manuring is resorted to-it will not be more than 30 arrobas. Some of the former coffee plantations of the north of Rio which gave abundant crops between 1850 to 1890 have been turned into pasture land and those which remain yield only 30 arrobas per 1,000 trees. New coffee

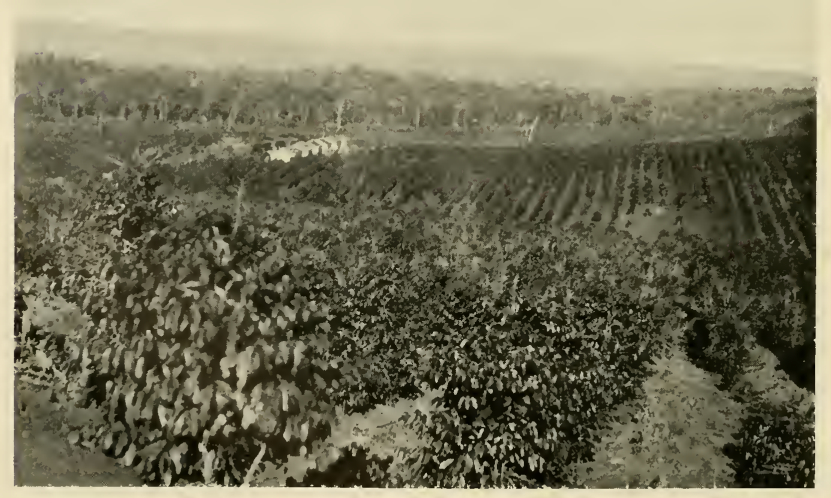

Coffee Plantation at "Sampaio Vidal" with Houses of the "Colonists" 


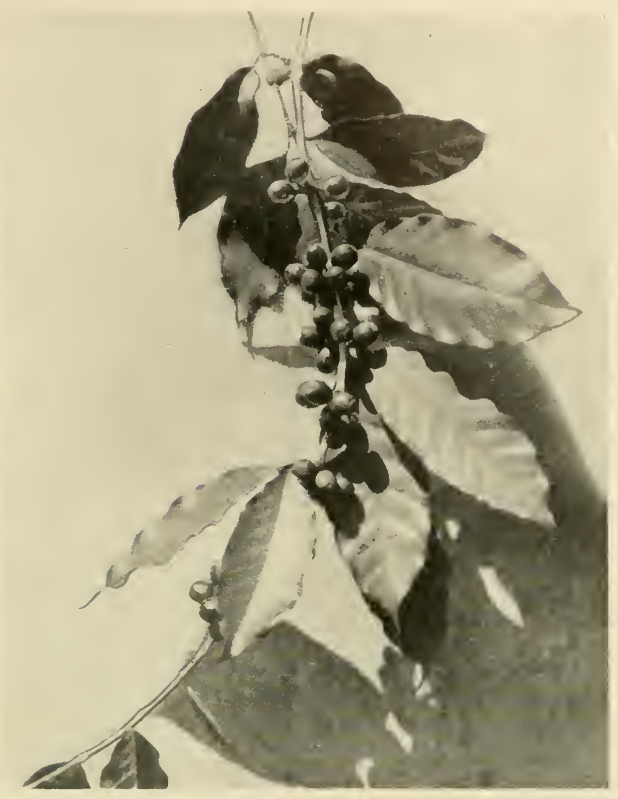

A branch of a Coffee Tree

plantations in the north are still giving 150 arrobas but coffee cultivation is more and more moving northwards and it is Mr. Braga's prognostication that in years to come it will finally settle on the Parahyba river and then São Paulo will be turned into a "cemetery of coffee plantations." This prophecy, I suppose, is to hold good only in case planters refuse to use chemical manures and thus restore the exhansted soil. A coffee tree will bear quite 40 years and it will be readily understood that after such a lapse of years the soil becomes poor. How it is to be achieved that the $834,000,000$ trees are to be regularly manured, or even half this number, is too difficult to imagine with the present density of population. Coffee cultivation even now, under ordinary conditions, requires considerably more labour than eotton.

Coffee has a fascination for the Paulista, but in view of the high cotton vields in the State and the ever decreasing coffee vields one cannot come to any other conclusion but that cotton will expand here in the near future at the expense of coffee. Cotton is already being cultivated amongst the coffee trees on many estates as a catchcrop, the workpeople are therefore becoming conversant with its method of cultivation. Moreover cotton would not suffer from the 
frost which every now and then devastates huge coffee plantations; before the frosts come the cotton is picked and, of course, only annual kinds are grown.

The coffee shrub is from two to four metres high, its leaves are of an oval shape, bright dark green, the flowers are at the base of the leaf stalk and form into fiery red cherries, in each of which are generally two coffee beans. The shrub grows best in a temperature hetween $15^{\circ}$ to $27^{\circ} \mathrm{C}$., but withstands even slight frosts for short periods. The flowers form from September to December and the cherries ripen towards May. The coffee shrub grows in every State of Brazil from Ceará down to Catharina, but as shown, São Paulo is the predominating coffee region not only of Brazil, but also of the world. The finely pulverized humus soil, known as "Terra roxa," of volcanic origin, which is found in extensive tracts in the Central and also in the North-Western parts of the State, is considered the ideal land for coffee plantations. The shrub suffers severely from strong winds, and frost above $1^{\circ} \mathrm{C}$. are fatal ; the latter occur frequently in the low lying areas, for which reason plantations are generally on high land, about 300 to 600 metres above sea level.

The seedlings are reared in a shady nursery at the fringe of the forest ; the value of a small plant ready for transplanting is one milreis, whilst the fully developed shrub is considered worth 3 milreis. Thus a coffee plantation of the size of that of Concle Prat, with about 900,000 shrubs represents a big value. The largest eoffee planter is Francisco Schmidt who started life in Brazil as an ordinary field labourer; his eompany owns now 52 estates, the capital is 15,000 contos.

The shrubs are planted in straight lines, $3 \cdot 5 \times 4.5$ metres apart, the soil requires to be kept free from weeds; on a properly conducted plantation five cleanings are made, and the shrubs are regularly pruned. After the third yĕr the shrubs begin to bear and continue generally for 30 to 40 years, but we saw some much older trees, one was said to be 120 years old. Weeding is generally done by means of the primitive hoe, though on some estates intercultivators are used. The soil underneath the shrubs is swept and any early ripening eherries which fall off can thus be collected. Often big sheets are spread out during the picking to eatch the dropping cherries. Many hands are required for the actual gathering, old men, women and children have to help, indeed the whole countryside is busy during the picking season.

A family of "colonists," as the tenants or labourers on a "fazenda" are called, looks after 1,000) coffee trees and all the crops grown between them. The terms on which these people are engaged are: "An annual payment of 150 milreis is made per 1,000 coffee trees. The cotton planted between the row is included in this wage. The gathering of the coffee-cherries is paid at 500 reis per 50 litres. When called upon to do dav-labour, they are paid $3 \$ 000$ per day. Cotton picking is paid extra at $1 \$ 500$ per 15 kilos seed cotton. Each family is allowed to have a row of Indian corn and a row of beans for their own use."

Immigrants and labourers from other parts get their railway fare paid, if they remain two years on the fazenda. Medical attendance is charged to the colonist at 500 reis per member of the family, per 
month. Only recognised feast days are observed. No colonist is allowed to leave the estate without permit. The colonist may buy his own requirements where he likes; he is not allowed to open a shop. Insubordination, habitual drunkenness or carelessness in work are justified causes for dismissal. Notice to leave must be given before June 20 th.

In the coffee zone there is always a searcity of labour and often the amount of land allowed to the colonist for his own use makes all the difference between lack of labour and an ample supply.

On an up-to-date plantation the cherries are put in a trough and washed (a good supply of water is available in most places in São Paulo), and carried by means of water channels to the pulping machine ("despollpador") which removes the fleshy part of the cherry, to be used later as manure, and leaves the berries free; they are at this stage still covered with a parchment skin. On leaving this machine the beans drop again in a water channel which conducts them to drying platforms ("terreiros ") where they are spread out and exposed to the heat of the sun. When dry, they are taken to the huller machine ("descascador") where the parchment skin is easily removed through the action of rollers, from there they pass to a fan which blows the skins and impurities away and finally they are elassified aceording to size into six different grades; on some "fazendas" polishing machines are used. The eoffee is packed in bags of 60 kilos.

The reader will see that many are the processes before the coffee bean is ready to leave the plantation which explains the statement previously made that coffee requires more labour than cotton.

When the bags reach Santos or Rio de Janeiro (the former is the principal coffee port), they are delivered to large warehouses where each bag is sampled on delivery. The coffee is then graded into eleven classes, of which number seven represents " good average," various deliveries are mixed together, the small beans are again separated from the large ones and the beans are then ready for being filled into bags. The machinery used for these various treatments consists mostly of sieves, automatic transporters and shoots.

On arrival at port 9 per cent. ad valorem export duty is payable.

Coffee is the great national drink throughout Brazil, almost at every street corner one finds a café where a small cup of coffee is sold at the low rate of 100 reis $\left(={ }_{4}^{3} \mathrm{~d}\right.$. with exchange at $7 \mathrm{~d}$.) and no tips are given. This has been the standard price of a cup for many years whether exchange was high or low.

There is no other product of Brazil which is so carefully graded as the coffee of São Paulo. The coffee grown in the other States of Brazil does not undergo this kind of classification, the quantity being so small, it would not pay to instal the necessary machinery. 


\section{Chapter V.}

\section{STATE OF MINAS GERAES.}

Area : 588,550 sqare kilometres.

Population : 5,527,900 inhabitants.

Capital : (Bello Horizonte), 50,000 inhabitants.

Measure : 1 " alqueire " in this State is equal to $220 \times 220$ metres $=$ 48,400 square metres.

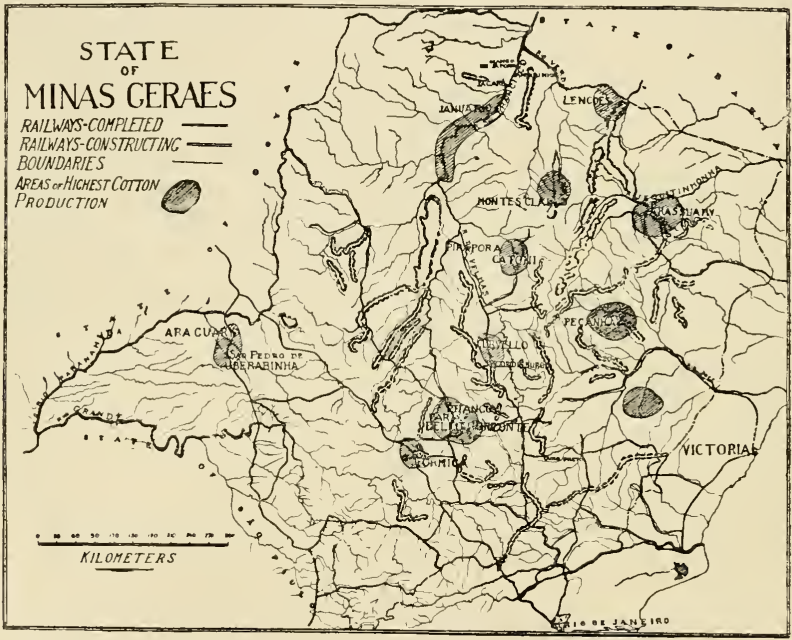

"Minas," as this State is generally called in place of Minas Geraes (= general mines) is bounded on the north by the State of Bahia, on the east by that of "Espirito Santo," on the south by those of Rio de Janeiro and São Paulo. According to the size, it is the fifth State of the Union, being more than twice the size of the previously described state of São Paulo. Minas is situated in the interior and has no seaport of its own; its traffic passes principally through Santos, Rio de Janeiro, some goes via Bahia and Victoria, in Espirito Santo.

The percentage of white people in Minas is 43 per cent., that of the mixed race 36 , and blacks represent 19 per cent.

"Minas" as the name indicates is more famous on account of its mineral wealth than its agricultural products, though it is more than questionable whether the latter would not produce more riches if as much labour were expended on it as on mining. 
The plateau from the south of Brazil continues through Minas, ranging in height from 400 to over 1,000 metres. Bello HoRizonte is the capital, which has been built by the Government as recently as 25 years ago. It is constructed on entirely modern lines with parallel streets, wide open spaces and presents a beautiful appearance. It was destined principally for the Government offices and the residence of the officials. The population is now 50,000, comprising mostly officials and those who eater for their wants. The town itself lies in a hollow, surrounded by mountains, has an excellent climatewarm during the day but cool at night. The atmosphere is dry.

The land of the south of the State is less fertile than the neighbouring State of São Paulo, indeed pasture for cattle is all that that vast portion up to the capital of Bello Horizonte and beyond seems to yield. Indeed it was only on the way to Pirapora, the terminus of the railway, on the São Francisco river, that cotton in anything like commercial quantities came to our notice.

The cotton zones of Minas are :

I. Pará-Pitanguy with Formiga, situated west of the capital.

2. Curvello, north of the capital on the railway to Pirapora.

3. Catoni-Montes Claros, in centre of the State.

4. Arassuahy and Peçanha in the east.

5. Lençoes do Rio Verde, north-east.

6. Araguary to São Pedro de Uberabinha, in the west.

7. The margins of the São Francisco river.

Besides in the above localities cotton is grown in almost every village; many out-of-the-way houses have their own cotton plot, the product of which is ginned on a small roller-hand-gin, practically of the same design as used in India; it is then spun by hand and finally woven on very primitive hand looms. In weaving the women push the shuttle with the hands from one side to the other; the fly-shuttle would save about 40 per cent. of the time.

The fact that cotton is grown so generally in many partshowever small the quantity may be-is proof that Minas is a probable field for the "future" supply of cotton for the world. I emphasize the word "future," beeause for the present the means of transport will hardly permit Minas cotton to compete freely with the cotton of other States. The cotton grown in Minas is not all used by the mills of the State, they buy a good deal of cotton from Bahia and further north, on which the transport expenses are very heavy. The Government and other interested parties should in the first instance aim at making the State self-supporting as regards cotton. This can certainly be achieved by seed distribution of one variety for each district for which purpose seed farms must be introduced. Such a step would save large sums to the mills in the form of freight economies. It is strange that Minas cotton should, even now, be exported and that at the same time the Minas mills should import more than half their requirements. The total consumption of the Minas cotton mills is estimated at $6,000,000$ kilos. The export tax on cotton from Minas 
is at present 4 per cent., but one of the modern ginning factories belonging to a company of Mr. Trajano de V. Medeiros at Pirapora has a concession of 25 per cent. reduction on this rate.

Owing to the difficulty of travel in Minas it was quite impossible for us to inspect closely more than the districts along the São Francisco river, but we examined also some cotton fields at Cordisburgo, and at Curvello.

The cotton produced in Minas varies in length of fibre from $\frac{1}{2}$ in. to $1 \frac{1}{2} \mathrm{in}$.; it ranges from coarse to fine, silky fibres. There are at least three varieties grown and generally one finds them all in one and the same field.

As we progressed up north the tendency was to keep annual cottons more than one year in the field. The shrubs are simply cut back at the end of the season.

The rainy season is from October to March, the dry season covers the rest of the year.

The land measure here is 48,400 square metres per "alqueire" which is, therefore, almost twice as much as in São Paulo.

The varieties of cotton growing are :

1.-The herbaceous kind, of American origin, often called "BIG BoLL" or "BIG Boffe," but it is seldom Russell Big Boll. The fibre is coarse, anything from 20 to $30 \mathrm{~mm}$., very often strong. People say that it resists the pink boll-worm and cotton leaf-worm better than other kinds, but where ants are this cotton cannot exist. This real annual plant is in most places grown for two or three years, i.e., the plant is cut off two or three inches above the ground after it has given a crop ; in the next season it sprouts out again and the new branches bear the crop. We were repeatedly told that in the second year the crop is heavier, if the pink boll-worm does not infest the field. The seed is hairy, with yellowish-green linters (ginning percentage about 30 per cent.).

2.- RIM DE Bor is a tree cotton, which has the curious "kidney" seed arrangement. Seven or eight seeds are joined closely together in two's with one at the head, resembling the formation of the rattle of the rattlesnake, or as the name indicates, the seeds are similar to the kidney of an ox. The seeds are practically bare of linters ; they cling closely together. The fibre of this cotton varies from 25 to $32 \mathrm{~mm}$. in length; it is finer than the herbaceous kind and is very strong. The colour of the lint is white but there is also a khakicoloured Rim de Boi cotton ; this latter is frequently used by the domestic spinners as it gives a nice effect in the cloth, without the necessity of dyeing. "RIM" cotton is often called "IN. TEIRo." The ginning percentage is only 18 per cent. and for this reason it is generally bought round the district of Pirapora with a discount of 20 per cent. on the other cottons. In Joazeiro and farther north in Bahia this cotton is very much appreciated by the hammock weavers and a premium, instead of a discount, is paid. 
3.-Crioula or Quebradinho, or Maranhão, or Miudo, is the third variety; it has a very small black seed with a sharp point, absolutely bare of any hairs. It is a tree cotton, remaining three and even five years in the soil. The fibre is very glossy, fine, varying in length from 24 to $35 \mathrm{~mm}$. In the Pirapora zone it does well, but along the São Francisco river the fibre does not develop in length and people say that it is more subject to insect attacks than any other kind. This seed is very similar to the "Mocó" seed of the Seridó. It is, however, smaller. The names of these cottons are constantly confused; they differ from one locality to another.

4.-Sertanejo Arboreo is a tree cotton, 15 to $25 \mathrm{~mm}$. It is very similar to Crioula. We found it only in Cordisburgo.

The astonishing feature about cotton in São Paulo and Minas is that one hardly ever sees a fibre that is not strong.

As a rule all these cottons can be met with in one and the same field and the majority of cultivators leave the shrubs growing for several years, but there are some who plant seed every year, in which case the American herbaceous kind is used.

Cotton in Minas is not generally cultivated on a large scale, but only by small holders. Indian corn is mostly grown in the same field ; it shoots up quickly and then the cotton plant is over-shadowed and has not enough circulation of air.

From the information given us we calculated that the average yield per acre is about 180lb. lint, whilst in the São Francisco it may be taken as $220 \mathrm{lb}$., but these figures are not very reliable as it is too difficult, in view of the many crops grown together, to obtain exact information on this point.

The land is prepared, in the more enlightened parts, with ploughs from June to August, but generally only a hoe is used. According to the first rainfall the seeds are planted between September and November. Picking takes place in June; generally there are two pickings. No rotation of erop is followed.

In each locality there is only one price for cotton, whether short or long, dirty or clean.

With the exception of the ginning factory of Mr. Trajano, S. V. de Medeiros at Pirapora, all the ginning plants are miserable installations, generally 18 to 30 saw-blades constitute the machine. They are all made by the American Eagle Company and are driven mostly by oxen, the machinery being similar to the ancient Persian water-wheel, viz.; a huge wooden cog-wheel turned by the animal works the shaft of the pulley from which a home-made leather strap drives the gin. It is in Minas where we have seen the most "inefficient" ginning.

The future of Minas as a cotton producer for the markets of the world lies a long way ahead. First the different types have to be separated; the people trained to better cultivation and to careful picking and ginning of cotton. Great possibilities do exist, but they are far from materialising in the near future. Mean while the means of transportation have to be improved for at present a good deal of produce 
is spoiled for want of ready communication with the large centres. The people seem hard working.

The modern ginning factory at Pirapora belongs to the "ComPanhia Viação E Industrial de Pirapora," one of the numerous Companies of Mr. Trajano S. V. de Madeiros. It may be of interest to state briefly the terms on which the Government of Minas has given to the Company the concession for the ginning factory and oil mill : a Government loan of 200 contos at 6 per cent. interest, re-payable in instalments within 15 years; no import duties on machinery, 25 per cent. reduction on the export duties, exemption from municipal taxes during the next 25 years and all land for the factory and experimental station were given free.

There are two large gins and a single American box press.

The Company has also an oil seed plant which is the more im. portant section as it is intended to bring up on the River São Francisco the cotton seed from distant parts where at present most of it is given to the goats and cattle for fodder. The present price of seed in those parts is 40 reis per kilo. The freight to Pirapora is calculated at 30 reis. The cost of jute bagging is probably as much as the cost of the seed it contains, for a bag holding 40 kilos of seed costs at present $1 \$ 200$.

In the oil plant what is called the "cold" process is used. This is applicable to all kinds of seed, whilst the "hot" process employed in the majority of cotton seed oil mills can only be used for this special seed. These machines were made by V. Anderson Company, Cleveland, U.S.A.

Pirapora is joined to Rio by $1,006 \mathrm{~km}$. railway, half on narrow gauge and half on broad gauge. This town is increasing rapidly, it is the great emporium for the goods which are handled by the river traffic, at the commencement of the navigable portion. Joazeiro is at the other end $1,369 \mathrm{~km}$. away, from there $576 \mathrm{~km}$. railway connects with the capital of Bahia, known in Brazil as São Salvador, but in Europe as "Bahia."

After the previous general remarks on cotton growing in Minas, details as to the conditions of cotton cultivation along the São Francisco river will be learnt from a perusal of the next few pages which are short extracts from my diary :-

\section{SÃO FRANCISCO RIVER}

The River São Francisco rises in the mountain range called "Canastra" in Minas and flows through the States of Minas, Bahia, Pernambuco, Alagôas and Sergipe, where it enters the Atlantic Ocean. The length of the river is $3,100 \mathrm{~km}$., 2,400 of which are navigable. Some small portions are, however, only accessible to boats during the rainy season and it may be said that regular navigation is established only between Pirapora, in the State of Minas, and Joazeiro, in the State of Bahia, a distance of $1.369 \mathrm{~km}$., of which 480 are in Minas and 890 in Bahia. This portion may be called the navigable stretch of the Upper São Francisco. The second part navigable throughout the year is between Piranhas and Barra, about $230 \mathrm{~km}$. in length where 
the "Paulo Affonso" falls check all progress of ships. This forms the Lower São Francisco and is situated between Alagôas and Sergipe. During the dry season navigation is very difficult, as there are many shallow parts; the draught of ships must not be more than $1.50 \mathrm{~mm}$. There are also some places with hidden rocks and fast currents.

A large number of tributaries of the São Francisco are also navigable but regularly established navigation exists only on the PARACATÉ Correntes and Rio Grande, with its secondary tributary Rio Preto.

The lack of more frequent and regular navigation is seriously felt and it was proved by a Commission that for want of transportation facilities large quantities of produce were rotting on the quays. In some instances consignments had to lie in the open for six months or more.

Those who desire to become more acquainted with the great possibilities of this river, are advised to study a large volume issued in 1860 by an engineer, M. Enrique Guilherme Fernando Hahlfeldwho made the first detailed survey of the river from 1852 to 1854 . This book, which has become rather rare, contains a number of maps and can probably only be obtained through Government offices in Rio de Janeiro; it is still the standard work on the São Francisco. A short and highly interesting description of the river, crops, minerals, etc., is found in a pamphlet by M. Alfredo dos Anjos, called "O Rio S. Francisco" and published in 1918 by "Estabelecimento Graphico F. Forgonovo," 91, Rua do Lavradio, Rio de Janeiro.

We travelled for eleven days on this flat-bottomed steamer stopping wherever anything of interest was to be seen or whenever our wood fuel had to be replenished. In the upper reaches near

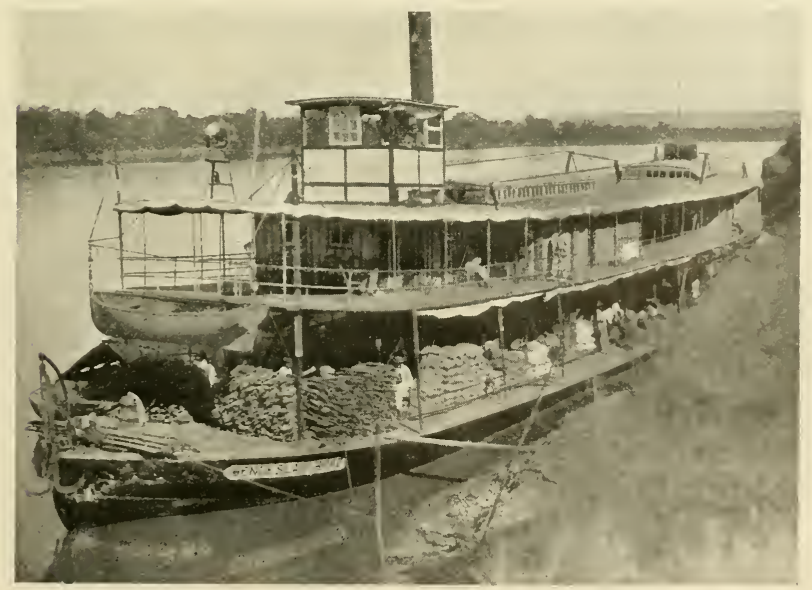

The steamer of the "Companhia Industria e Viação de Pirapora," on which the Mission travelled 
Pirapora the river was very shallow and sandy. Whenever the steamer went aground, which occurred pretty frequently-mostly during the night, the sailors, all powerful men nearly all of the negro type, jumped overboard with crow-bars and bodily levered the steamer off. These men worked very hard and were always full of humour and pleasant. After a few days journey, the water-level became so low that we had to stop during the nights. The navigation is almost entirely done according to the appearance of the surface of the water. On nearing Joazeiro there are some difficult stretches to navigate on account of hidden rocks coming within a few inches to the surface and often covering almost the width of the river, indeed in some cases the open passage between these rocks is very limited and the current extremely swift. Before this part of the country can be properly opened up a great quantity of the hidden rocks will have to be removed, as navigation is too precarious.

Similar rapids are also on the Lower São Francisco, when approaching the Paulo Affonso Falls.

On this river journey we had the pleasure of the company of Dr. Octavio Carneiro, the chairman of the Companhia Industria e Viação de Pirapora, one of the many enterprises of Mr. S. V. Trajano de Medeiro.

São Francisco was our first port, $229 \mathrm{~km}$. from Pirapora and $1,140 \mathrm{~km}$. from Joazeiro. It has 3,000 inhabitants. There is one gin with 25 saws which had not been sharpened for three years though every year fully at work.

There is a great confusion of names of the various cottons. What was known in Pirapora and the rest of Minas by "Creoula" is here called "Inteiro" or "Rim de boi," etc. Only one price is paid for all cottons, whether long, short, dirty or clean. The growers did not know that the length of fibre, cleanliness, strength, etc., contributed any value to the cotton.

One bale screw press worked by hand, similar to the one shown in accompanying illustration, was the only press used. Indeed this kind of press is typical right through the interior. The best cotton in all the mixture was the small black seeded cotton, spoken of in this place as "Quebradinho," measuring $34 \mathrm{~mm}$. All the cotton was very dirty.

There are two markets in the town for the sale of the produce and for weighing purposes, but cotton is not sold there. I suggested that town authorities should induce the growers to sell their cotton in the market; that proper regulations on the lines of the Indian and Egyptian cotton markets should be established.

The American kind "Big Boll " is much affected by ants, whilst Creoula legitima (Quebradinho) withstands them. The season for picking was just beginning (end of May). The seed is planted October, November and December. All the cotton is grown mixed with Indian corn. Land is held by families; the value of land is estimated at anything from 10 to $80 \$ 000$ per alqueire of 48,400 square metres, but when buying a large estate, land can be had much cheaper ; in fact, some little distance away from the river, land can be had at a nominal charge. Probably the lawyer's expenses would be as much as the value of the land. 


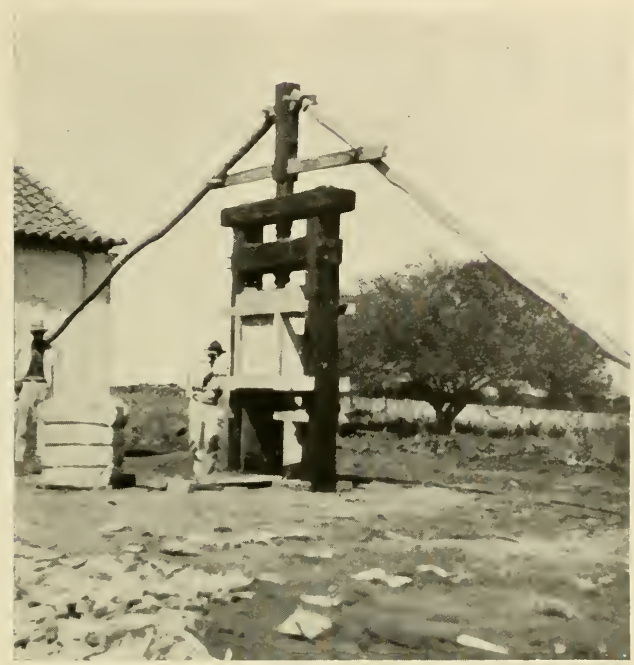

Primitive Hand Screw Press for Cotton Bales, in general use up-country

Field workers receive $2 \$ 570$ per day. The share system is in vogue in these parts. For picking cotton the payment is $1 \$ 200$ per 15 kilos; a woman or a child can pick on an average only 15 kilos per day.

We visited also a plantation on the other side of the river; in one and the same field there was rice, beans, grass, Indian corn and cotton. The owner could not tell us what he made on cotton. All the different varieties of cotton were to be seen. Creoula takes nine months to mature, but as they have no rain at that time of the year, this long period of maturing does not interfere. There was a great deal of "Big Boll" in the field, and some of it was good.

About every ten years the land is flooded; it is a slow inundation, depositing alluvial soil. Occasionally heavy floods come; the last one was in 1919 of which all the towns and villages still bear traces of devastation, many of the houses having fallen in and have not been re-built. The water must have risen some $25 \mathrm{~m}$. on that occasion and for months the people had to take refuge on the neighbouring hills.

JANUARIo: $1,055 \mathrm{~km}$. from Joazeiro, $314 \mathrm{~km}$. from Pirapora.

All the different kinds of cotton, except the "Inteiro" (or "Rim de boi ") are called here "herbaceo"; the people grow the usual sorts, all mixed up.

One gin had worked three years without sharpening saws. It was driven by oxen, the gearing being on the model of the old-fashioned Persian wheel. In this place we saw some women spinning by hand, 


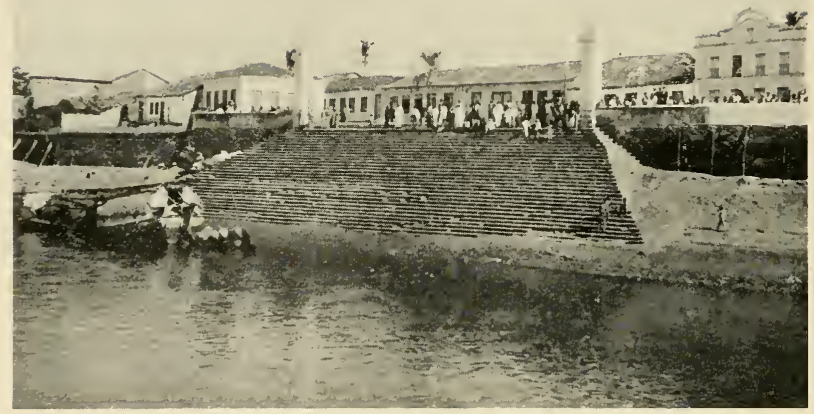

The Landing Stage at Januario

also hand-weaving. Pillow-lace making is one of the principal occupations for women and children in all these villages and the photograph below shows mother and child at work. Coats' sewing thread is given the preference over the Pedra thread of Brazilian manufacture, was the information given by these women, but Coats' thread was dearer and more difficult to obtain.

The left side of the river in Minas is more fertile than the right side, as there is more water on the left. For this reason the virgin

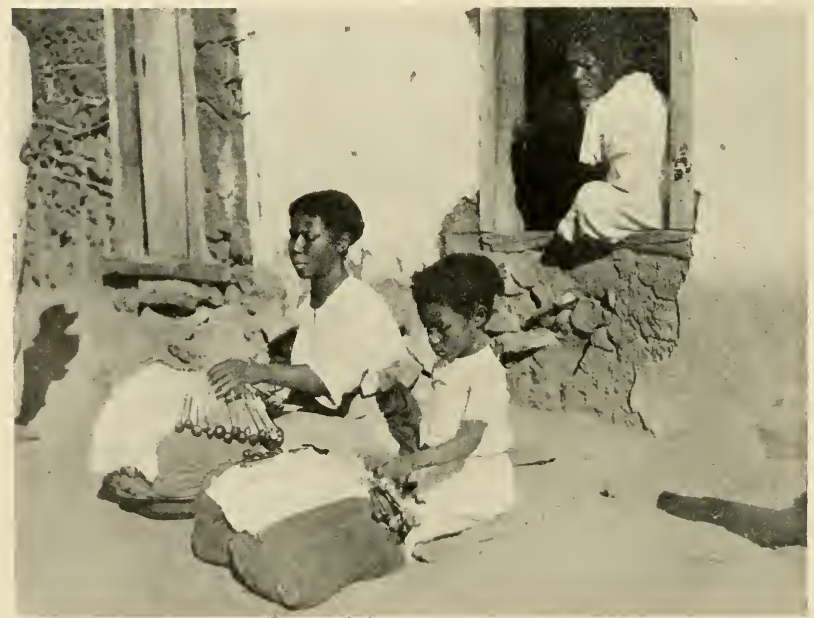

The Making of Pillow-Lace is a great Domestic Industry all along the São Francisco River and in the whole of North Brazil 
forests come closer to the river. These forests contain fine hard woods. Transportation and other expenses of the wood to Rio de Janeiro are calculated to be $100 \$ 000$ per cubic metre, whilst the wood can readily be sold at twice that figure in Rio.

In this district "Succuris," a kind of "boa constrictor," abound. They had recently found one of great length, $10 \mathrm{~m}$. and more, which had died through swallowing a "Capybari" (resembles wild pig but is actually a rodent). During the week prior to our arrival five "succuri" snakes had been brought into the town. The skins are used for many purposes.

JACARÉ : $364 \mathrm{~km}$. from Pirapora, $1,005 \mathrm{~km}$. from Joazeira.

The name of this place means " crocodile." All along the Upper São Francisco crocodiles are very numerous.

We visited two ginneries, both mule, or oxen driven, called here "bolandeiras." One of the gins had worked six years and the other sixteen years without any sharpening of the saws; each gin had about 20 saws. The proprietor of one ginning factory had a spare set of saws, but he did not consider it necessary to replace the worn-out ones. In one factory they had 2 hand-presses turning out bales of 60 and 80 kilos. One man bought on the basis of an arroba of 15 and the other of 16 kilos.

In this district "Rim" is cultivated little as it is attacked by insects. The present price, regardless of length of staple, etc., of all seed cottons is $5 \$ 000$, but for "Rim," on account of low ginning outturn, it is $4 \$ 000$.

The only people who know what a good quality of cotton is are the women accustomed to spinning and weaving. The men in the cotton business never dream of looking at the fibre.

MANGA DE JAPORE : (426km. from Pirapora, $943 \mathrm{~km}$. from Joazeiro).

This is the largest cotton exporting port in Minas. We visited a field about $3 \mathrm{~km}$. outside the town; it was a mixture of an American kind, much hybridized, and the black seeded cotton, known here as "Maranhão," which is the same as "Creoula" in the south. The hybrid American was, in places, long, about $30 \mathrm{~mm}$. and strong; in others it was very short. The Maranhão was not yet ripe.

In a ginning factory we saw a gin with 18 saws which had worked without attention to the saws for ten years. The pile of seed in the factory from last year was all a mixture.

"Rim" is not much cultivated here and from what we could see and learn the American kinds of cotton seem to do better in this zone than any other varieties. This is quite contrary to the experience of the southern parts visited by us. People say that the American herbaceous kinds withstand insects better than the others.

Prior to Manga we stopped a short time at Morrinha, where spinning and weaving are carried on to some extent by the women.

Almost every household along the São Francisco River has in the garden a primitive funnel made of wooden sticks, each about four feet long, in which wood ashes are filtered, in this way providing potash. Vegetable oil is added and the mixture serves as soap. 
This finishes the description of Minas. It must be stated that cotton in small patches is grown all along the left side of the river from Pirapora to São Francisco, but some distance away from the river. There is a large cotton zone on the right and left bank of the river "Rio dos Pandeiros," which is a tributary of the São Francisco, joining the latter below Januario. Cotton from here is brought to Januario, Jacaré and Manga. On the right side is a cotton zone behind Morrinho, along the Rio Verde.

On the Rio dos Pandeiros is a waterfall, 35m. high, not yet used for hydro-electric purposes.

Besides cotton Minas produces coffee, Indian corn, rice, black beans, tobacco (for which Minas is famous), sugar cane, potatoes and manioc or mandioca. The latter is a root of a shrub which is ground to flour and as in the interior bread is seldom baked, meat and vegetables are generally covered with mandioca flour ("farinha") in substitution of bread.

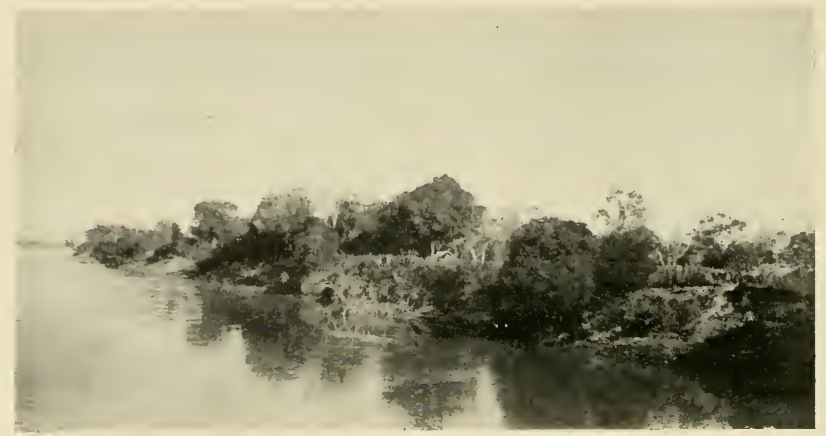

A typical View of the Vegetation along the Banks of the Upper São Francisco River 


\section{Chapter VI. \\ STATE OF BAHIA}

Area : $536,110 \mathrm{sq} . \mathrm{km}$.

Population of State : 2,500,000 inhabitants (1912).

Capital : Bahia (São Salvador), 300,000 inhabitants.

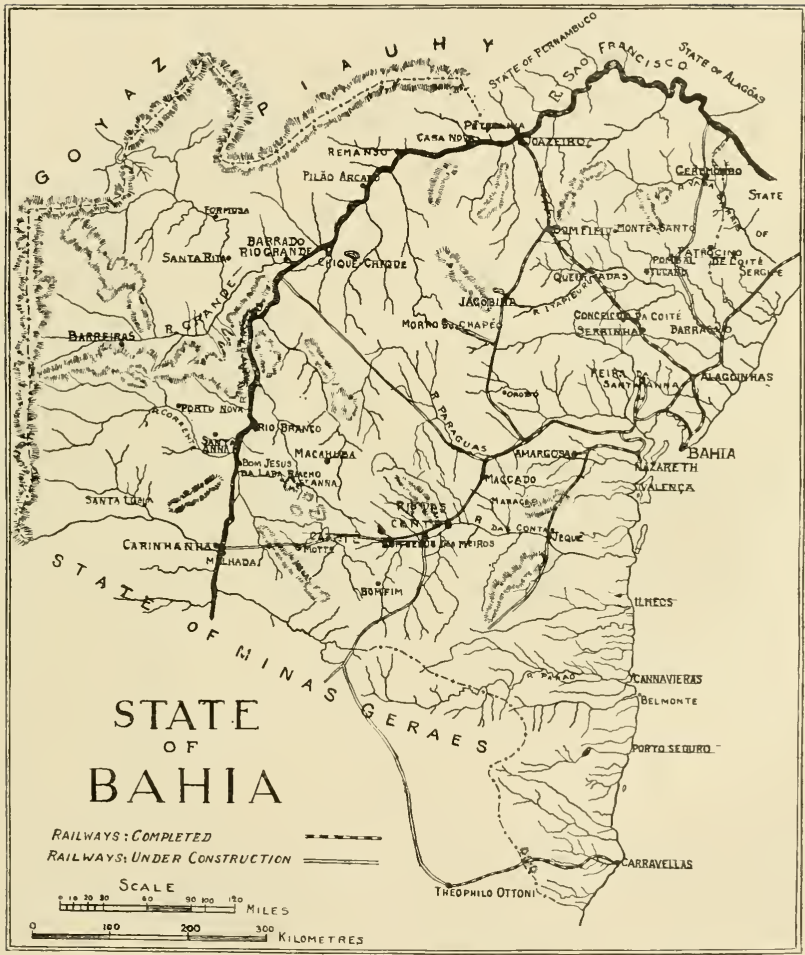

The State of Bahia, on account of its large area and varieties of climates is able to produce crops of the tropical, sub-tropical and temperate zones.

Bahia has a long sea-coast, is bounded in the north by the States of Sergipe, Alagóas, Pernambuco, Piauhy and in the east by Goyaz. In the south is "Minas" the neighbouring State. 
The Cotton Zones of Bahia are the following, together with the quantities of sacks of cotton sold to the cotton mills of Bahia from Ist July, 1920 to 30 th June, 1921, as per latest report of the "Centro Industrial do Algodão," Bahia :

\begin{tabular}{|c|c|c|c|c|c|c|c|c|}
\hline $\begin{array}{c}\text { ORDER } \\
\text { OF } \\
\text { IMPORTANCE }\end{array}$ & \multicolumn{7}{|c|}{ MUNICIPALITIES } & SACKS \\
\hline 1 & \multirow{2}{*}{\multicolumn{3}{|c|}{$\begin{array}{l}\text { Morro do Chapéo .. } \\
\text { Bom Jesus dos Meiras }\end{array}$}} & .. & .. & .. & .. & 2,801 \\
\hline 2 & & & & .. & .. & . & . & 2,400 \\
\hline 3 & \multirow{2}{*}{\multicolumn{3}{|c|}{ Pombal $\quad \ldots \quad \ldots$}} & . & . & . & . & 2,000 \\
\hline 4 & & & & .. & .. & .. & .. & 1,128 \\
\hline 5 & \multicolumn{3}{|c|}{ Patrocinio do Coité } & .. & .. & .. & .. & 1,030 \\
\hline 6 & \multicolumn{3}{|c|}{ Remanso .. ... } & . & . & . & .. & 859 \\
\hline 7 & \multicolumn{3}{|c|}{ Minas do Rio de Contas } & . & .. & . & .. & 851 \\
\hline 8 & Bomfim & .. & .. & .. & .. & .. & .. & 714 \\
\hline 9 & Barra & .. & .. & .. & .. & .. & .. & 659 \\
\hline 10 & Geremoabo & .. & .. & .. & .. & .. & .. & 602 \\
\hline 11 & Barreiras & .. & .. & .. & .. & .. & .. & 512 \\
\hline 12 & Ituassú & $\ldots$ & .. & .. & .. & .. & .. & 428 \\
\hline 13 & Tucano & & . & . & . & . & . & 351 \\
\hline 14 & Santa Luzia & & .. & $\ldots$ & .. & . & .. & 347 \\
\hline 15 & Jequié & . & . & .. & . & . & . & 307 \\
\hline 16 & Barracão & .. & .. & .. & .. & .. & .. & 259 \\
\hline 17 & Orobó & .. & .. & .. & .. & .. & .. & 245 \\
\hline 18 & Casa Nova & .. & .. & .. & . & .. & .. & 144 \\
\hline 19 & Nazareth & .. & .. & .. & .. & .. & .. & 134 \\
\hline \multirow[t]{2}{*}{20} & \multirow[t]{2}{*}{ Maracás } & \multirow[t]{2}{*}{.. } & \multirow[t]{2}{*}{.. } & \multirow[t]{2}{*}{.. } & \multirow[t]{2}{*}{. } & \multirow[t]{2}{*}{.. } & \multirow[t]{2}{*}{. } & 127 \\
\hline & & & & & & & & 15,898 \\
\hline
\end{tabular}

During the same period the Bahia mills had to import cotton as per particulars below :

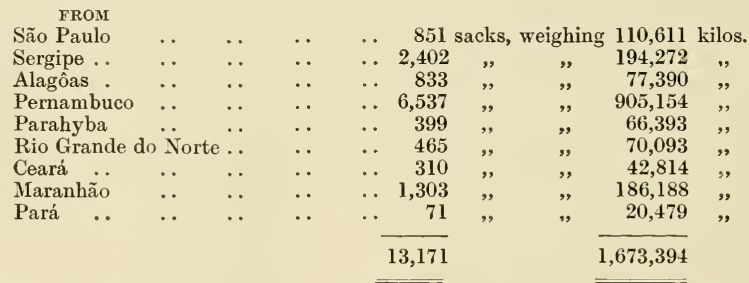

There are only 96,964 spindles in Babia. Some considerable quantities of cotton grown in the eastern part of Bahia, along the São Francisco, are often sent to Minas and this export is likely to increase, as the merchants here do not like the introduction of an official classer by the Commercial Association of Bahia. All lint cotton entering the mills of Bahia is graded, according to the clean or dirty condition, into three classes; for the first the normal market price is paid, for the second ten per cent. and for the third twenty per cent. discount are taken off. Under such conditions it pays the small merchants at the São Francisco river to sell their cotton, especially the dirty class, to Minas, where no such differentiation exists, though they have to pay higher transport charges. 
There is no export tax in Bahia, but various little taxes, such as agricultural administration tax $1 \cdot 5$ per cent., statistical tax $2 \cdot 2$ per cent. ; in all, these levies come to $3 \cdot 7$ per cent.

In Bahia we got to know the cotton along the São Francisco and that grown along the railway between Joazeiro and the city of Bahia. We also examined the various cottons in the stores of the mills.

The quality of cotton and the conditions under which it is grown vary in this State so much that a short extract from my daily notes will probably convey a more correct idea than an attempt at generalising.

\section{SÃO FRANCISCO RIVER (continuation)}

Following on the São Francisco river from the last description in the previous chapter on Minas we got to MaLHADA, $481 \mathrm{~km}$. distant from Pirapora and $888 \mathrm{~km}$. from Joazeiro.

Our next stop was at CARINhanha, $483 \mathrm{~km}$. from Pirapora and $886 \mathrm{~km}$. from Joazeiro.

Opposite this town there is an estate belonging to Mr. Augusto Jaep, called "Cerra do Ramalho," which is said to be well-managed, but it was too distant for us to visit.

Land is very cheap here ; one man bought 500 square kilometres for 50 contos in 1915 .

As soon as one enters the State of Bahia one is forcibly reminded that polities, sometimes local, sometimes of State nature, play a very important part in the lives of the people. The question of having street lights or not, was the primary cause of a revolution in a neighbouring place, "Carinhanha," which lasted several months and spread to surrounding districts, also to Malhada. There are frequent political turmoils in the State of Bahia, and when the European reads exaggerated statements of these in his newspapers, the conclusion is often drawn that this state of affairs applies to the whole country, which, of course, is entirely wrong. These disturbances are of a local nature. It is true, politics occupy the minds of people in every State to a great extent to the detriment of business, but generally differences are adjusted without bloodshed. In Bahia this is not the case and Malhada and Caranhanha bear traces of a violent passage at arms. Many buildings show the bullet holes, even churches have not been spared. Devastation has been increased by the great flood which took place in 1919. Many houses on the high bank of the river were destroyed and at the time of our visit were not yet restored.

There is a new ginning factory at this place, its gin has 50 blades, it is driven by an English steam engine, the boiler is also English, but there was no cotton to gin. In normal times this port is of importance as the cotton from Bella Flores, Monte Flores and Caiteté is brought here. This cotton is now shipped from "Bom Jesus de Lapa " and has to be carried a greater distance on muleback before it reaches the boats.

At a small place called VoLTA we saw a little field containing mostly "Inteiro" cotton, measuring $32 \mathrm{~mm}$., its fibre was strong and silky. It was the second year of its growth. 


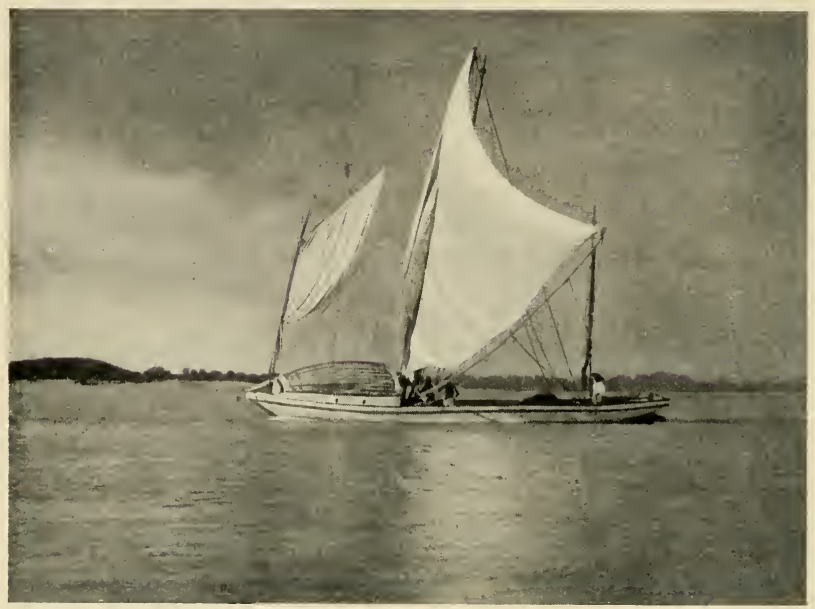

On the Lower São Francisco River

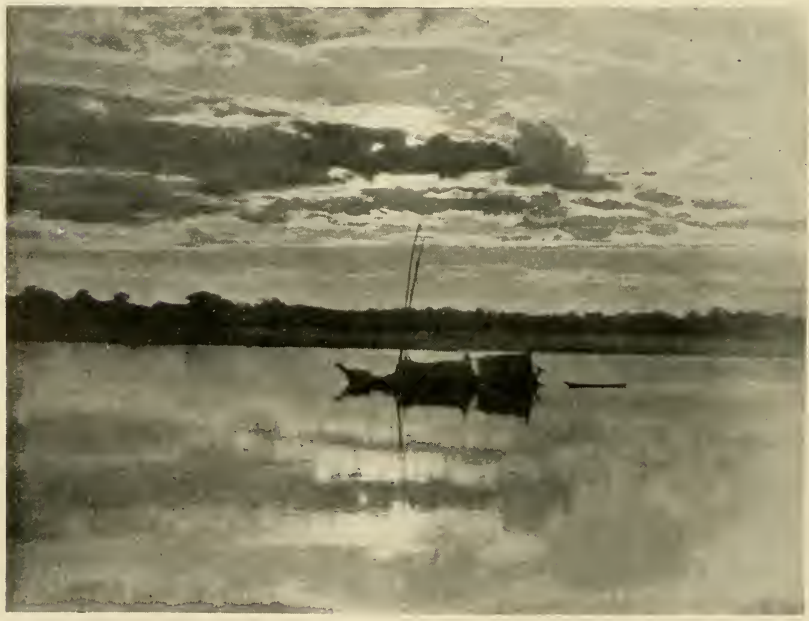

On the Upper São Francisco River 
Barrero Grande, or Volta Grande, as it is sometimes called.

We inspected a saw-gin sold by Schill's of Manchester. It had worked for four years without attention to the saws. The gin was driven by the old-fashioned arrangement, known as "bolandeiro." The bales were pressed by a hand-press. The cotton varied from $15 \mathrm{~mm}$. to $32 \mathrm{~mm}$.; it was all mixed up.

"Inteiro" cotton was not good and the cultivator said that it was easily attacked by insects. In this district the "annual" kind (covered and naked seed) seemed to do better but, strange to say, only two miles away from here the contrary obtained.

Bom Jesus De LAPA : 748km. from Joazeiro, 621km. from Pirapora.

We met a rather intelligent cultivator in this place who was able to supply us with a little more information than we were able to obtain in other parts along the São Francisco.

As everywhere, cotton is planted with the first rains which, in this district, take place in October ; it is ready for picking from May but continues to give lint until September. Preference is given to the "herbaceous" kinds which remain here in the ground for at least two years. Undoubtedly it would be better if they were planted every year and the field burnt off after the first crop, because it is in the second year that the cotton worm does great damage. The cultivators allege that, if in the second year the cotton worm does not appear in great numbers, the yield is much higher than in the first year. Information supplied to us shows that the yield per acre works out to $220 \mathrm{lb}$. lint in a field where Indian corn is grown as well. One cotton merchant, who is also farming, maintained that if only cotton were grown without Indian corn, the yield should be 50 per cent. higher. This question of growing eotton as a mixed crop with Indian corn has certain advantages for a small man, as it ensures that either one or the other of the crops will turn out satisfactory, but undoubtedly the height of the Indian corn must be a disadvantage to the development of the cotton plant as it prevents the circulation of light and air.

Maranhão cotton is said to be more liable to attacks of insect pests. "Inteiro" cotton is well liked here. It is grown especially on the islands of the river and one plant is said to yield as much as 8 kilos seed cotton. "Inteiro" cotton is not killed by the floods.

Generally speaking, the more distant future of cotton in this district is good, but at present there is a shortage of hands. 'This place is the outlet of the Bella Flores and the Caiteté zones.

The "annual " plants have taken on the arboreal character.

There was a ginning factory with 25 saws, driven by a steam engine. We saw some cotton in the store, already ginned, that had come on mule back a distance of 40 leguas (each legua $=6 \cdot 5 \mathrm{~km}$.) from Monte Alto-Riacho de Sant Anna; it was of an inferior kind.

The people here believe that when an eclipse takes place during the maturing of the cotton, the crop must be a poor one. The same superstitious belief was expressed to us in several other parts of Brazil, thousands of miles away. 
Rio Branco (formerly known as Urubú) : $666 \mathrm{~km}$. to Joazeiro, $703 \mathrm{~km}$. to Pirapora.

There was one gin, 30 saws, not yet fitted up, as this year there has been no cultivation of cotton in the immediate neighbourhood.

Close to this place the "Rio Corrente" joins the São Francisco river on the left side. On it are situated Santa Maria and Porto Novo, forming a considerable cotton zone. Here is a road through to the State of Goyaz in the heart of Brazil ; Goyaz is saicl to produce excellent cotton and to have very fertile soil but lack of railway and river communication has so far prevented this cotton entering the world's markets.

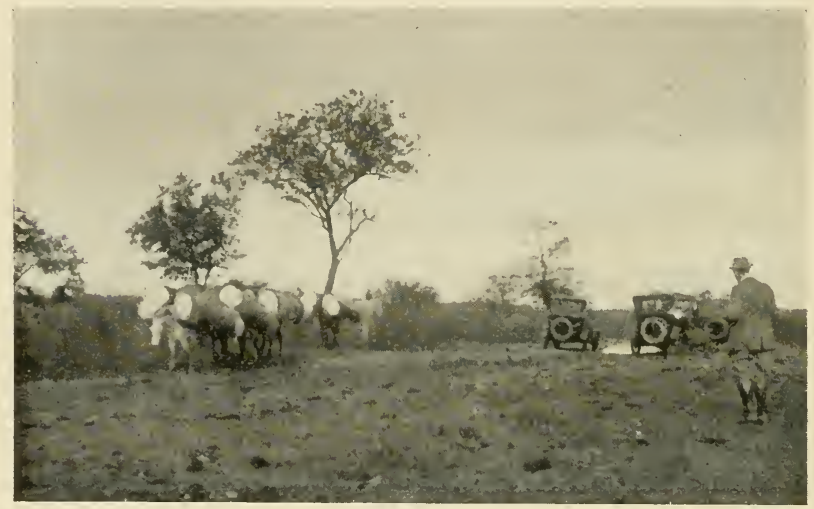

\section{Pack-Mules with Country Bales of Cotton.}

The usual Method of Transportation in the Northern Parts of Brazil (64 kilos each bale); often 30 and more mules follow

Riacho Sant AnNa: 24 leguas away, has several gins.

Macaubas : 16 leagues away, has one gin. Both places send cotton to Rio Branco, but the major portion goes to Lapa. On an average some 1,000 bales of cotton are shipped every year from Rio Branco. Poço DO MEL :

"Inteiro" cotton, $32 \mathrm{~mm}$., crossed with the herbaceous variety, covered seeds instead of naked, fibre strong, bright white, but less silky. Little damage by insects. The cotton is used for domestic purposes.

The "Quebradinho" (black seed, naked) was short-26mm. BOM JARDIM :

This is the port for CANNABRAVA, a cotton district some 22 leguas away and here was the worst ginned cotton we have ever seen. It is transported on mules, 2 bales of 60 kilos each, cost of transport= $15 \$ 000$ for the two bales. 
The yield of cotton was given as being $280 \mathrm{lbs}$. lint per acre as a mixed crop. It is a good district but short of hands.

Freight from here to Joazeiro is $1 \$ 100$ per 16 kilos. So far, some 200 arrobas have been sold to Joazeiro at $7 \$ 500$ per arroba, including cost of freight. Both "Inteiro" and "Quebradinho" are liked, the latter especially is good-up to $35 \mathrm{~mm}$.

Fazenda Torrinha, owned by Dr. Francisco B. Mariani, whom we had the pleasure of meeting.

The "tarefa" here has only 4,000 square metres, instead of 4,356 square metres as in other parts; we were told that if cotton were planted alone it would yield about 700lb. per acre but with a mixture of Indian corn in the same field it gave only $380 \mathrm{lb}$. The ginning out-turn of the cotton here is 31 per cent. lint. On this farm there were produced about 8,000 kilos lint. This gentleman had never thought of looking at the length of fibre, all cotton being paid, of course, one uniform price; he had not troubled about selecting seed, etc.

This farm is especially engaged in cattle raising and the owner complained that the people were not very good workers, that they preferred fishing and the shooting of "egrets," which are plentiful in these parts.

Barra do Rio Grande: 439 kilos from Joazeiro, 930 kilos from Pirapora.

This is the port for Goyaz and Piauhy States ; cotton of excellent quality also comes from Barreiras on the Rio Grande $(789 \mathrm{~km}$. from Joazeiro). The Rio Preto is a tributary of the Rio Grande and I am told that the region between Santa Rita and Formosa is well suited for cotton growing.

The yield near Barra do Rio Grande is said to be 700lb. per acre, but here cotton alone is planted; there is no rice nor Indian corn in the field.

Quebradinho was $32 \mathrm{~mm}$. and Herbaceous $28 / 30 \mathrm{~mm}$.

There is a gin with 40 saws driven by steam. The cotton was badly ginned, although the gin was comparatively new and working only two years.

From here begins the cultivation of the CARNAUBA PALM, the leaves of which supply the well-known wax used sometimes in sizing warps; a description of the primitive manner, in which the wax is obtained is given in the last chapter. The tracle in this wax is becoming every year more important.

Chique-Chique or Xique-Xique : $359 \mathrm{~km}$. from Joazeiro, $1010 \mathrm{~km}$. from Pirapora.

This district was closely surveyed a short time ago by Mr. L. Zehntner, a Swiss who is an official of the Bahia Government; he recommended it specially for cotton growing (see Report in "Boletim da Agricultura 10-12, October to December, 1920, Secretariat of Agriculture, Bahia).

The annual American kinds of cotton are grown here almost exclusively but they are left in the ground for three years. Some- 
"Quebradinho" is also cultivated but the American kinds are preferred. We were told that the second year gives the best yield. In this district the cultivators have again given up cotton on account of the low price. At present $3 \$ 000$ per 16 kilos seed cotton is paid and as the yield per acre in mixed fields is only 120lb., cotton is no more a paying crop ; for picking wages alone half the above price, namely $1 \$ 500$ has to be paid. Land is very cheap. For $36 \mathrm{sq} . \mathrm{km}$. three contos were recently paid. The picking in this part of the country is disgracefully performed. The people shake the cotton from the trees and let it fall to the ground, then scoop it up, along with sand and dirt. Cotton from this district has always been classed by the Bahia people as seconds and thirds on account of the dirty condition. The nearest gin is $60 \mathrm{~km}$. away and another one is situated $120 \mathrm{~km}$. distant. Generally, the agricultural conditions of ChiqueChique seem very neglected. One farmer had bought a plough and an American inter-cultivator, but he could not get anyone to use them. The wages for day labour are $1 \$ 500$ per day. The cotton seed is thrown to the animals, as it does not pay to transport it to any oil mill. The goats especially are fond of cotton seed.

The reason why agriculture is neglected is probably due to the fact that Chique-Chique is an excellent fishing place and fish sells at $10 \$ 000$ per 15 kilos against cotton at $3 \$ 000$. Fishing is an occupation which does not call for continuous labour and consequently suits the people better than agriculture.

The supply of fish is very plentiful and the fishing season is from May until October; on an average 8,000 "surubis" are caught, weighing on an average $10 \mathrm{lb}$. but some of these are as heavy as $80 \mathrm{lb}$. The fish is dried and sent to Bahia.

Some $60 \mathrm{~km}$. away from Chique-Chique there are found tourmalines, diamonds, white and black, lead, saltpetre and crystals for lenses. The mines also take people away from agriculture.

Pilão Arcado: 278km. from Joazeiro, 1,091km. from Pirapora.

The only buyer of cotton is Col. Franklin Lins d'Albuquerque. The cotton from this place is classified by Bahia as second class. $\mathrm{He}$ buys about 70,000 kilos every year and cultivates about 70 acres himself. Three years ago he lost 80 per cent. of his cotton through the pink boll-worm, the following year he exposed his seed before planting for several months to the sun, with the result that he lost only 10 per cent. of his erop through pink boll-worm. He had received information, through Pernambuco, of this remedy. We had heard of the same remedy in São Paulo.

The yield per acre is 220lbs. of lint. This farmer pulls up the plants every year, burns the stalks and selects his seeds. The seeds from the first bolls are taken for planting. The ginning percentage is 33 per cent. of his own cotton, but that bought from other farmers yields only 27 per cent. The cotton he buys is mixed with "Quebradinho." He considers that land is worth about 3 to 5 contos per $36 \mathrm{sq} . \mathrm{km}$.

Wages : $1 \$ 500$ per day; plenty of workpeople.

Picking: 700 reis per 15 kilos.

Price of cotton to-day: $3 \$ 000$ per 15 kilos. 
Mr. Lins has two gins, one 25 saws and the other 36 . A kerosene motor drives the gins. Bales of 90 kilos are pressed by a hand-serew. All cotton seed is given to animals.

Bahia buyers deduct in purchase 4 per cent. discount for prompt cash, unless four months' credit is given, and a further 10 per cent. is deducted as Bahia classifies his cotton as No. 2.

Railway freight from Joazeiro to Bahia is almost $2 \$ 000$ per 15 kilos lint. Cost of transport from Pilão Arcado to Bahia $=7 \$ 000$ per arroba. If Mr. Lins sends his cotton to Minas he has to pay about 800 reis per 15 kilos in taxes.

The principal crops are Carnauba palm leaves, mandioca and Indian corn. Fishing takes up a lot of the time of the people. There is no share system. Those who rent land do not pay any rental. The landlord is satisfied to have somebody on the land, on whom he may call for help against payment of a daily wage. The products of such tenants are sold to the landlord ; by these means the landlord probably earns what he loses on the rent.

Remanso: $202 \mathrm{~km}$. to Joazeiro, $1,167 \mathrm{~km}$. to Pirapora.

A tarefa here has only $2 \mathbf{2 5} \times \mathbf{2 5}$ braças of $2 \cdot 20$ metres each.

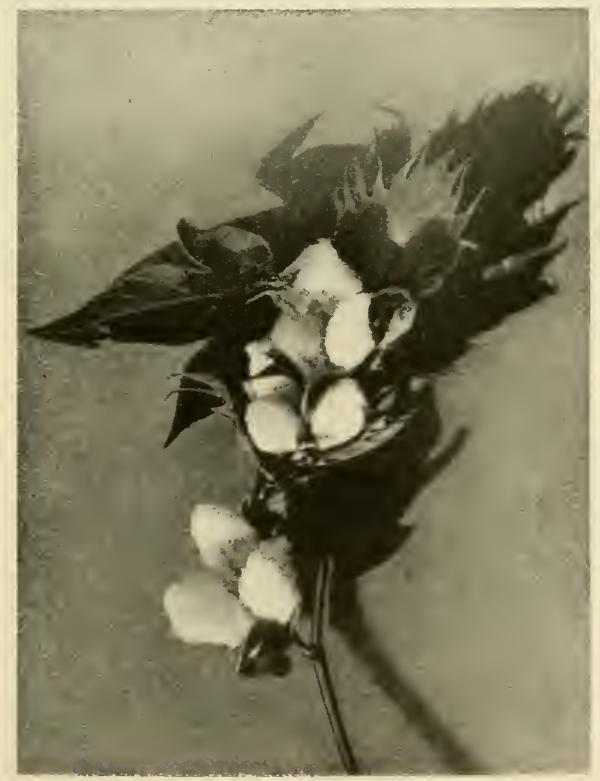

Verdào Cotton 
"Inteiro" is cultivated; in the first year it vields 16 arrobas, in the second year half that quantity and in the third only about 6 . The farmer had not pruned his trees, consequently only very few new branches had formed.

At this place we first became acquainted with "Verdão" cotton which gives an excellent fibre. In this district it measured from 30 to $34 \mathrm{~mm}$. It is a cotton which is said to have been introduced some four years ago from Pernambuco. Its outstanding feature is its silkiness and in every case it is strong; it has large bolls and is easily picked. From here upwards to the north this cotton is met with under various names. Of course, it is mixed with other kinds. Efforts should be made to get this cotton pure. It has a very promising future; especially the strength and silkiness appealed to us and the farmers generally agree that it is a heavy yielder. The seed of this cotton is very easily recognised as it is large and covered with green (sometimes blueish-green) hairs, for which reason it is also known as " green seed" or " blue seed" ("verde," "Azul," "azulão," etc). It is called in some places "riqueza," meaning " wealth," then again " rompe-letras," equal to " debt-payer," which are significant names.

Verdão in these parts remains two to three years in the ground, but farther north it grows for five or six years.

A gin with 35 saws and a kerosene engine is in the village." We saw some bales of 60 kilos cotton that had come from Piauhy, São Raymundo; it had $30 \mathrm{~mm}$. and was ginned there. One mule takes two bales (a bale in the north is called "mala"); the journey is 18 leguas $=110 \mathrm{~km}$. and costs $10 \$ 000$ per mule load.

There are 1,300 bales of this cotton in the town, waiting for a higher price.

\section{Casa Nova : 75 kilos from Joazeiro, 1,294 kilos from Pirapora.}

Hand saw gin with 20 saws. Screw bale press. Cotton in the store all mixed : Herbaceo, Inteiro, Quebradinho and Verdão.

Verdão had a fine glossy fibre, about 30 to $32 \mathrm{~mm}$., seed large, verdigris colour. A farmer who had made his own experiments with this cotton said that it was a marvellous yielder, bearing bolls right from the bottom. Sometimes the cotton was ripe 3 months after sowing, but in other districts it takes twice as long. The plants are left three years in the soil without pruning.

\section{JOAZEIRO :}

There is a ginning factory with 30 saws; some blades had a number of teeth broken out. "Verdão" cotton is liked, but hammock makers prefer the "Inteiro" cotton and pay a considerable premium for it. Ginners will not trouble to separate the "Inteiro" seed cotton, a work that could be performed by a child. Though they would get a higher price, they do not trouble.

Three varieties are known here: "Herbaceo," amongst which they include "Verdão" and all shrub plants; "Inteiro" (known here as "Creoula") and "Quebradinho." There was a very large amount of dead fibres amongst the cotton pile in the gin, not so many leaves. 
During the whole of our journey we saw only on one oceasion that a woman was employed at a ginnery in scparating the bolls of dead fibres.

We noticed a clear Hybrid of " Inteiro," being covered all over with the verdigris linters of "Verdão." Indeed, though "Verdão" is only a recent introduction. the apparent hybridization which has taken place and which is at once visible on account of the green hairs on the seed, is a striking fact, noticeable all over the north.

There were in the ginning factory a number of cotton bales, packed in palm-leaf canvas from Pilão Arcado; this was rery dirty cotton of short staple.

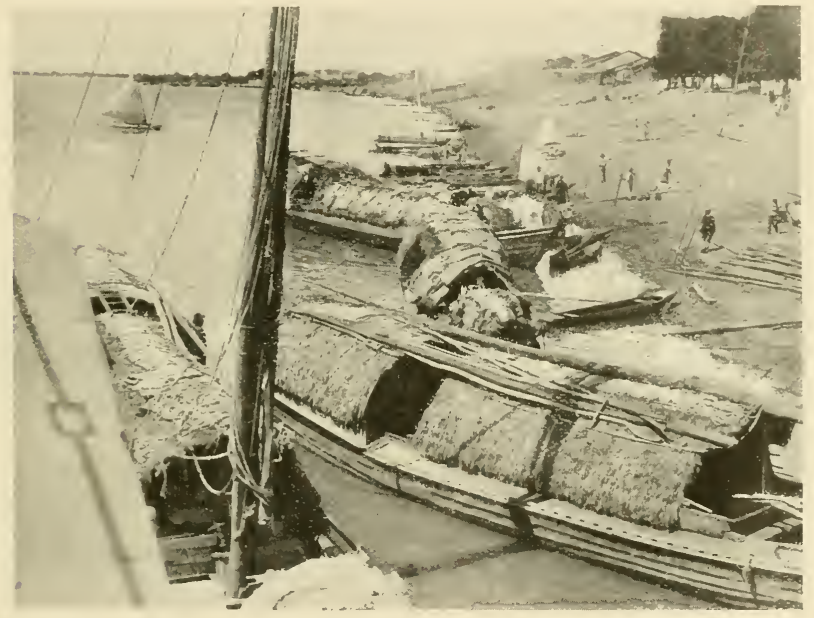

On the banks of the São Francisco, near Joazeiro

Joazeiro is the emporium at the end of the navigable part of the Upper Rio São Francisco and cotton is sent to it from the interior of the Pernambuco State as far away as 100 to $120 \mathrm{~km}$. ; it comes unginned on muleback. Cotton also enters from Casa Nova, $90 \mathrm{~km}$. away and from the district of the "municipio" of Joazeiro, $60 \mathrm{~km}$. in circumference.

A distance from the town is the "Horto Florestal," an agricultural experimental station, belonging to the Federal State Government. It suffered severly from the flood of 1919 and there was no cotton plantation there when we visited the place.

The Director, Dr. Paulino d'Araujo Gaes, promised to plant several hectares with cotton; he is evidently working under great difficulties, owing to shortage of money. There is an excellently managed orphanage for boys and girls run in connection with the experimental station. 
The Director stated that he had made in former years experiments as to pink boll-worm in three fields:

No. 1 was not irrigated and had no pink boll-worm.

No. 2 was irrigated every third month and had pink boll-worm.

No. 3 was irrigated every month and the crop was all eaten up.

Calcareous soil, in his opinion, gives a silky fibre.

An experimental agricultural station close to a commercial town, whose inhabitants are only interested in buying and selling, seems almost out of place.

There is a ginning factory at Petrolina (corruption of "Pedra linda " meaning "beautiful stone," there being a huge rock in the market place).

Petrolina opposite Joazeiro, on the other side of the river, is still a small place, but is growing visibly and likely to become a very important centre as a railway from the Port of Maranhão is being constructed which will have its terminus at Petrolina and bring the produce from that State and of Piauhy. Petrolina is situated in the State of Pernambuco whilst Joazeiro is in the State of Bahia.

At Joazeiro navigation for steamers ceases and our journey now took us by rail through the State of Bahia. Arrangements had been made for our special train to stop at the principal cotton centres.

Our first call was at Bомғiм (55l metres above sea-level) which is $444 \mathrm{~km}$. from Bahia. We inspected the gin of Messrs. Ramos Queiroz \& Co. ; it has 40 saws and it is driven by a kerosene engine.

All kinds of cotton were mixed, viz. :

Inteiro - not much-5 years in ground, length of fibre, $28 \mathrm{~mm}$. Verdão .. $\quad . \quad 2 \quad, \quad$, , pruned back, .. $323 / 34 \mathrm{~mm}$. American, large black seed _. $\quad$. $\quad \ldots$ planted every year. White-haired seed . .

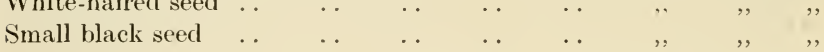

Six years ago no cotton was grown here; it was introduced by the above firm and cotton is now liked by the farmers. When cotton is very sandy, they riddle it over a sieve, which is shaken through an eccentric contrivance. There was also a seed disinfecting chamber for the purpose of killing the pink boll-worm.

The following is a copy of a Sale Note of Mr. Ramos' cotton bought by a large Bahia mill.

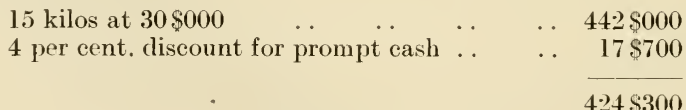

Expenses :

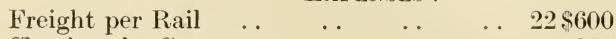

$\begin{array}{lllll}\text { Classing the Cotton. . } & \ldots & \ldots & \ldots & 2200\end{array}$

$\begin{array}{lllllll}\text { Commission } & \text {. } & \ldots & \ldots & \ldots & 8 \$ 800 & 31 \$ 600\end{array}$

Net Balance in favour of Mr. Ramos $\quad \ldots \quad \ldots \quad 392 \$ 700$ 
Why the mill charges the man two per cent. commission I do not know, as the mill uses the cotton.

This is a peculiar district. The main crop takes place in June, but there is not a single month in the year when cotton is not picked. Shrubs bear almost every month, as after every shower new blossoms form. There are many showers throughout the year.

This ginner pays $4 \$ 000$ for clean cotton and $3 \$ 000$ for dirty cotton; in one week he had received as many as 700 odd lots, from one lb. to $440 \mathrm{lb}$, , totalling $7,310 \mathrm{lb}$. All are mixed up. This shows the necessity for a uniform seed for the whole district, otherwise mixture of all kinds must take place, as the ginner cannot keep such small lots a part.

The railway freight from Bomfim works out at 102 reis per kilo, i.e., more than pre-war rate of freight from the U.S.A. to England.

Near to the town of Bomfim we found an abandoned house with garden in which there were some 50 trees of cotton, mostly "Inteiro," largely infested with pink boll-worm, but the fibre was fully $42 \mathrm{~mm}$. long, some $45 \mathrm{~mm}$., strong and silky.

$3 \mathrm{~km}$. outside Bomfim the Federal Government is on the point of establishing an experimental cotton station.

The railway journey from Bomfim takes one through enormous stretches of once cultivated, but now abandoned, land overgrown with shrubs and cacti of all kinds. Near IтUiBa the train passes for miles through a narrow valley and on the top of either side is a tableland which is said to be suitable for cotton. This district suffers from drought every five or six years when the only food for the cattle to be found around are the many cacti, the thorns of which they break off with the horns.

\section{QueIMADAS :}

Gin with 20 saws (working four years without sharpening). Kerosene engine 3 h.p. "Verdão" cotton is liked best. 36 to $38 \mathrm{~mm}$. in length. Usual mixture of all kinds; cotton is brought in from "Monte Santo," 8 to 10 leagues away.

\section{SANTA LUZia :}

There are three gins, one with 30 saws, another with 20 and the third with 40 ; two driven with kerosene engines and one with steam (wood as fuel). "Verdão" good, $34 \mathrm{~mm}$.; it is not much attacked by pink boll-worm, but "Inteiro", is.

The crop begins August to September and whenever there is a shower a new crop comes on.

\section{SERRINHA :}

One gin with 72 blunt saws. Kerosene motor.---The fibres are short and weak and the cotton musty ; it seemed intentionally damped.The picking is in August and September.-This was formerly a large cotton district but owing to the low price the acreage has been reduced considerably.

A zone of great importance is Morro DE ChaPEO, which sends the cotton via Jacobina per rail to Bahia; we could not visit the district, but we saw the cotton in the Bahia mills.

In the State of Bahia (São Salvador) I was invited by the "Centro Industrial do Algodão " to give a lecture on the impressions gained 
during our visit through the State. The President of this organisationMr. Alberto Moreas Martins Catharins - was in the chair. There were present: the Minister of Agrieulture, eotton spinners, merehants, etc. We also ealled on the Governor of the State and explained to him the reforms required.

The "Centro Industrial " eomprises all the spinning mills of the State. The President eomplained severely that they have to import cotton from other States whilst Bahia produces even now more than is necessary for the eonsumption of the mills. It is said that half the erop is sent to Minas, especially from those parts along the São Franeiseo. This eotton ought to pay the State tax, of $2 \cdot 2$ for statisties and $1 \cdot 5$ for agrieultural administration, in all $3 \cdot 7$ ad valorem, but very little of the cotton raised there pays this tax for that eountry is too far away from the seat of eontrol. The "Centro Industrial do Algodão" made an offer to the Government to buy the land and implements for three eotton farms in the State of Bahia, provided that the Federal Government and the State of Bahia each find 200 eontos. The parties are likely to eome to an agreement.

The classer who grades all the cotton which eomes to the Bahia mills is in the employment of the Commercial Assoeiation of Bahia. The draw-back in eonnection with the elassification of the eotton is that the price difference of 10 per cent. between the first and seeond elass is not sufficient. In Pernambueo this difference is 50 per eent. As a matter of faet, at one ginnery we noticed a man using a quantity of unripe, matted and damaged cotton, and when I drew his attention to it he explained that this would not eause his eotton to be graded into a lower class than No. 2 and he did not see why he should not get paid for the dead fibres as he had to pay for them.

The length and uniformity are not taken into eonsideration in this classification.

Our journey now took us north towards Sergipe. The rainy season had not yet terminated when we visited these parts and though we had arranged to stop, at several stations and make excursions, we found the roads impassable even for horses.

Our speeial train stopped at Alagoinuas, where eotton has reeently been introduced. The usual mixture was grown. Cotton is planted in April and in three months it is ready for picking. "Verdão" was again the best variety in the mixture, but it was only $28 \mathrm{~mm}$. long. The silky character was preserved. The farmer thought that this shortness was due to the fact that this cotton sample represented the end of last year's crop. The yield was given as being 275lbs. lint per acre.

Time did not allow us to visit all the eotton produeing districts of Bahia, but we examined the cottons either at the ginneries or at the cotton mills. We came to the conclusion that the "Verdão" variety is, in every ease, the best and that the cotton along the São Franciseo river is better than that found in the other places.

There are great possibilities in Bahia as regards "Verdão," and a Seed Farm specialising in this kind of eotton would undoubtedly give excellent results. Another advantage in the State is that eotton grows practically all the year round. 


\section{Chapter VII.}

\section{STATE OF SERGIPE}

Superficie : $23,368 \mathrm{sq} . \mathrm{km}$.

Population : 450,000 inhabitants.

City of Aracajú : 35,000 inhabitants.

Density : 19 per sq. km.

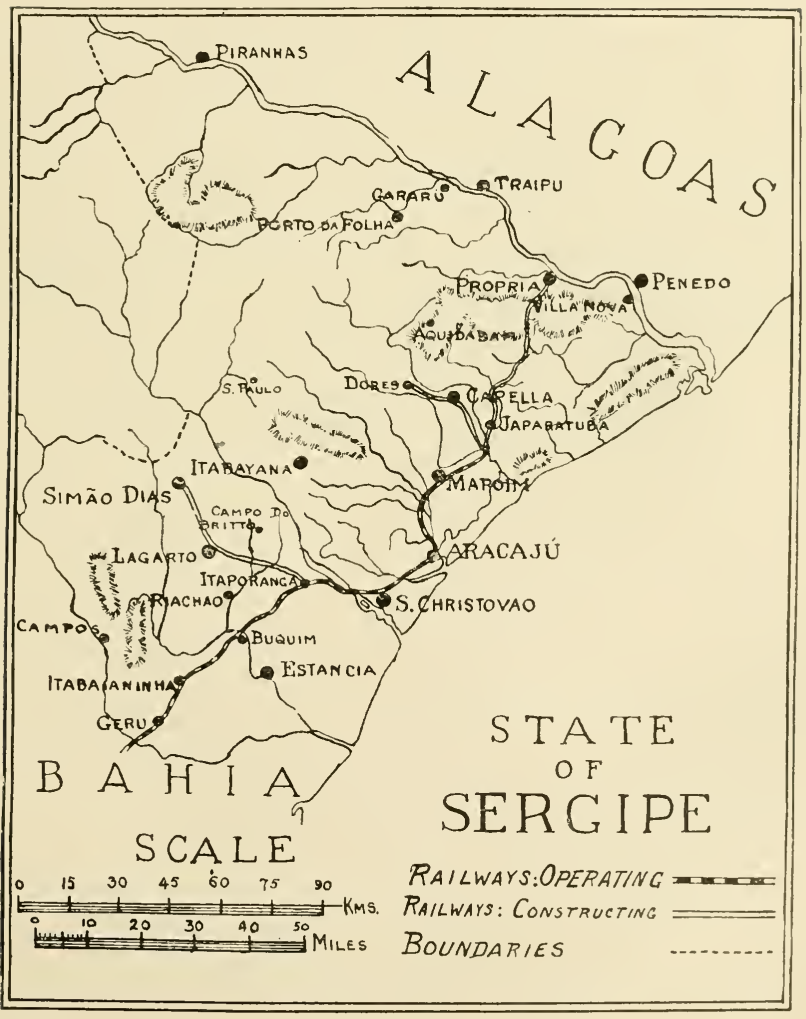


Sergipe is the smallest State: it is shaped in triangular form, the eastern side being open to the Atlantic Ocean; the western side has Bahia as a boundary and the north-eastern portion connects with the State of Alagôas, the river São Francisco forming the natural boundary. Aracajú, the city and seat of the Government, is the principal port. The coastal region is low but the interior has mountains and plateaus.

This State is practically dependent on sugar and cotton; Indian corn, beans and rice are also grown, but sugar and cotton are the staple crops and the Government fully realise this fact and have organised a special Cotton Department which has been instrumental in bringing into force an excellent decree for the protection of cotton (No. 270, 4th March, 1921).

The General Secretary of the Cabinet-Dr. Alvaro Silva-awaited the arrival of our special train at the station of Aracajú and with us visited two cotton mills of that city. We then paid our respects to the President of the State, His Excellency Engh ${ }^{\circ}$. Col. Pereira Lôbo.

The whole Cabinet understands the cotton question and they are prepared to do what is in their power, but as both sugar and cotton have fallen in price considerably the State has had very reduced incomes as its only source is the export tax on cotton which for 1921 was fixed at 8 per cent. ad valorem. Until the previous year this tax was 9 per cent. ; it was reduced by request of the Cotton Department of the Federal Government.

It has been recognised that the export tax is an impediment in the fostering of cotton exports, but where the State has no other revenue it will be almost impossible to abolish it or even reduce it considerably unless a new system of taxation is evolved.

The Government have recently built a fine entrepôt-warehouse where the cotton of the whole State will shortly be classified. At present only a small portion enters it because the organisation is not yet complete. The cotton is weighed there and graded into three classes by a coloured gentleman. No regard is taken of the length of fibre in this classification, he merely takes into consideration the cleanliness of each lot. We were shown a lot of cotton, some of which was graded into classes 1,2 and 3 , and I took the samples and mixed them up from the order in which they were given to me, then asked the classer to say which was class 1 and which was class 2 . His first guess was wrong. I asked for the standard samples according to which the cotton was graded, but there were none in existence. We drew the attention of the Government officials, including the Governor, to these shortcomings, and they promised to introduce the necessary reforms.

The small amount of exports of cotton from Sergipe is due to the fact that the eight cotton mills in the State, containing 52,710 spindles, consume almost the whole of the production of cotton.

In $1920,59,680$ tarefas $=17,145$ hectares grew cotton, and gave a crop of 65,000 bales of 75 kilos lint, which works out to a yield per acre of about $175 \mathrm{lbs}$. lint. Here again it is a question of mixed cultivation with other crops, otherwise the yields would be higher.

The cotton which we have seen in this State is very uniform, more so than in any other State so far visited. Generally it was $28 \mathrm{~mm}$. 
strong and white. The crop was not ready at the time of our visit. Picking takes place here in August-September. Owing to the rainy season and the bad state of the roads it was quite impossible for us to visit the fields so we had to content ourselves with examining the cotton at the ginneries and the cotton mills.

Besides our stay at Aracajú, we stopped at Buquim, s. Christovão (the old capital of Sergipe), Maroim, Japaratuba, and Propria.

The ginning factories of Sergipe have an excellent method of cleaning the cotton prior to ginning : a hexagonal sieve-drum placed in a slanting position with meshes 9 by $6 \mathrm{~mm}$. receives the cotton at the top and the loose cotton is thrown gently from one side to the other by the rotation of the drum at about 35 to 40 revolutions per minute; the cotton gradually works its way to the outlet at the lower end from where it is taken to the gin. This simple contrivance does not damage the "bloom" of the cotton.

Out of 2,850 kilos of seed cotton which pass through one sieve, over 50 kilos of dust and foreign matter were extracted daily.

At JAPARATU Ba we witnessed the cotton arriving from AqUIDABAN. The bales were insufficiently covered with bagging, the whole front and two sides of each bale were uncovered. It was raining heavily and the cotton not being densely pressed of course became saturated right through. These bales had come a distance of 24 kilos and during the journey they had experienced several heavy tropical showers.

The Federal Government has started four experimental cotton farms in Sergipe at Annapolis, Dôres, Propria and São Paulo, but none of them was quite ready at the time of our visit.

The country is divided into four cotton zones, viz. :

(1) Nossa Senhora das Dôres with the following places-

Dôres (most important)

Capella

Maroim

Aquidaban (important)

(2) Propria with-

Propria

Gararú

Porto da Folha

Villa Nova

(3) São Paulo with-

São Paulo

Itabaiana (important)

Campo do Britto

Dist. da Carira

(4) Annapolis with-

Annapolis

Lagarto

Riachão

Buquim

Estancia

Campos 
The cotton here consists of "Quebradinho," "Creoula" and "Verdão." The fibre is about one inch in length and sometimes slightly longer. "Verdão" is preferred.

The planting season is in February-March and picking begins in August and lasts until January.

"Annual" cotton is allowed to remain two years in the field; it yields at times after only three months. "Verdão" remains four years and after the second crop it is generally pruned.

The bales weigh 70 to 80 kilos.

The tarefa in Sergipe is 25 by 25 braças of $2 \cdot 20 \mathrm{mts}$. $\left(3 \frac{1}{3}\right.$ tarefas $=1$ hectare).

The vield of cotton was given as 90 kilos per tarefa lint of "Quebradinho" and as 120 kilos of "Verdão."

At SÃo Christovão we inspected a mill with 8,000 spindles and 250 looms, making only white goods. There was a gin at the mill which worked very badily. At Aracajú we visited two other mills. Wages here are on the average $1 \$ 500$ per male and female operative.

At Propria we visited another spinning mill with two gins having 40 saws, which had many broken teeth. The slanting sieve was in operation. The owner liked "Inteiro" cotton best but this is grown only to a small extent, after that he liked "Verdão" and he agreed that we did right in recommending the Government to distribute only that seed. In the pile of cotton at this mill there was again an excellent variety : it seemed a hybrid of "Inteiro" crossed with "Verdão."

As the Sergipe mills spin 18's on an average any of the existing mixtures is good enough for them and this is probably the reason why no improvement in the cotton has taken place, but we are convinced that the State of Sergipe may contribute considerably to the export of cotton if attention is given to separating the various qualities and planting only one kind, preferably Verdão, or Riqueza, as it is called here. 


\section{Chapter VIII.}

\section{STATE OF ALAGOAS}

Superficie : $206,915 \mathrm{sq} . \mathrm{km}$.

Population : 800,000 .

Density : 30 per sq. $\mathrm{km}$.

The capital is Maceió and has 40,000 inbabitants.

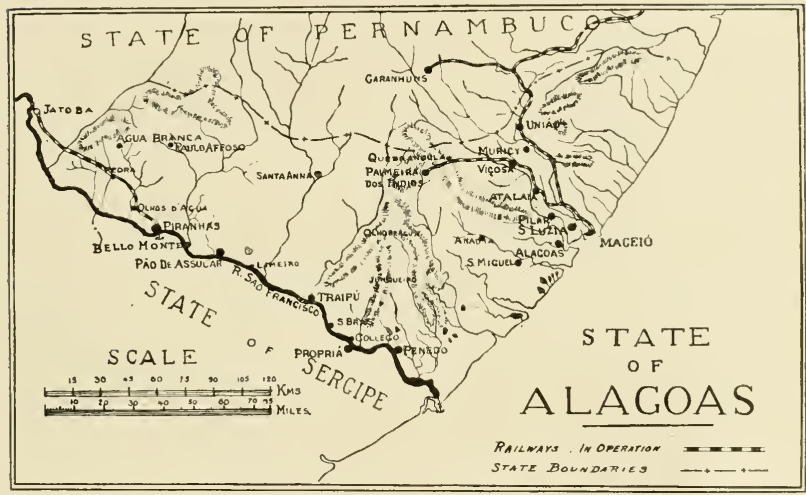

Alagoas is the second smallest State to Sergipe. It is situated north of the latter on the left side of the São Francisco river. It has a frontage to the Atlantic Ocean with Maceio as an important harbour. In the north its boundary is Pernambuco.

The State of Alagôas is chiefly sugar producing, but of its 35 municipalities the following may be mentioned as growing cotton: Agua Branca. Paulo Affonso, Piranhas. Pão de Assucar, Bello Monte, Traipú, São Bras, Colegio, Penêdo, Junqueiro, Sant'Anna de Ipanema, Palmeira dos Indios, Victoria, Viçosa, Limoeira, Anadia, Santa Luzia, Leopoldina; others produce sugar and cotton, viz. : Parahyla, Atalaia, Pilar, Alagôas, São Miguel, São José da Lage, União and Muricy.

There are 10 cotton mills in the State, with 50,000 spindles; we visited only the cotton thread mill of Pedra, of which I have given a description in chapter II.

A steamer took us from Propria up the Piver São Francisco, but after a few hours our boat ran on a sand bank. We then continued our journey in a "canoa," a native boat of small dimensions, but had to scek shelter on account of a heavy storm, meanwhile our steamer got off the sand bank and soon overtook us. 
At Pào D'Assucar (5,000 inhabitants), a port on the São Francisco, we stopped in order to inspect the ginneries which handle every year about 3,000 bales of 180 kilos. This town makes a busy impression. The cotton of this district is almost identical with that we saw in Sergipe. Mixture exists here as well and Verdão is the best variety in it. There were also some good hybrids between "Inteiro" and "Verdão."

The bales of cotton we saw in the streets and in the port were not properly covered.

After 36 hours steamer journey we arrived at Piranhas, from where we took the train to Pedra.

Through the courtesy of Mr. L. Iona, the managing director of the "Companhia Agro Fabril Mercantil" at Pedra, we were enabled to travel per motor cars the distance of $360 \mathrm{~km}$. to Garranhuns in Pernambuco: this road was to a great extent constructed by this cotton mill company and is kept in repair by it. Wherever we passed cotton fields we stopped the cars. The cotton in these parts was beginning to open and we were enabled to examine it. On our journey we obtained the following information :-

At InнapI, municipality of Matta Grande, the yield worked out to $165 \mathrm{lb}$. lint per acre.*

A mixture of Verdão, Quebradinho and Maranhão is grown, but cotton alone occupies the field.

The custom in this district is for the tenant to rent the fields at 10 milreis per " quadra," paying cash : a three years' agreement is general. The tenant has to provide a wooden fence, a kind of wattle fence; the branches for this basket work fence are provided by the trees felled when clearing the land. The cost of these fences works out to $\mathbf{1 2 0}$ reis per $\mathbf{2} \cdot \mathbf{2 0}$ meters. As cattle are kept in large numbers in the whole of the north, all fields have to be fenced and the wattle is the one in use.

\section{LAGôA DO Algod̃̃o :}

The only additional information to be obtained was that cotton sold at the time at $1 \$ 600$ per arroba of 16 kilos.

Sant'Anna do Ipanema :

This is a town of considerable importance.-Before we could enter it we had to get six men to repair the road, which had been washed out owing to the heavy rains. The town has two ginning factories and in the municipal district there are altogether 14 . The cotton passing through this place is estimated at 4,000 bales of 75 kilos per annum. The cotton is generally carried on mule-back, one mule taking a maximum load of 160 kilos to the railway stations of Garranhuns, 180 kilos away, or to Quebrangula, 150 kilos, at a charge of $12 \$ 000$ per load.

A labourer's wage is $1 \$ 500$ per day. One of the ginners told us that he pays at present $2 \$ 500$ per "arroba" of 16 kilos clean cotton and $2 \$ 000$ per " arroba" for dirty cotton.

*In these parts they use the following measurements :-1 quadra $=2$ tarefas ; 1 tarefa $=25 \times 25$ braças; 1 braça $=2.20$ meters. 
"Verdão" was again the best fibre; the ginnery was full of the usual mixture. The factory we inspected had two gins with 50 saws each, a cleaning sieve and two screw presses worked by hand. Last year this factory dealt with 1,200 bales of 75 kilos. The daily production is 30 bales. The cleaning sieve takes $300 \mathrm{lb}$. of dirt daily out of the 15.000lb. of seed cotton which is handled.

When the bales are sent per ox eart they are made to weigh 110 kilos.

Planting takes place in May- June and the cotton is ready for picking in about three months. A most unusually quick period of growth, but in all this district of Alagôas this information was confirmed.

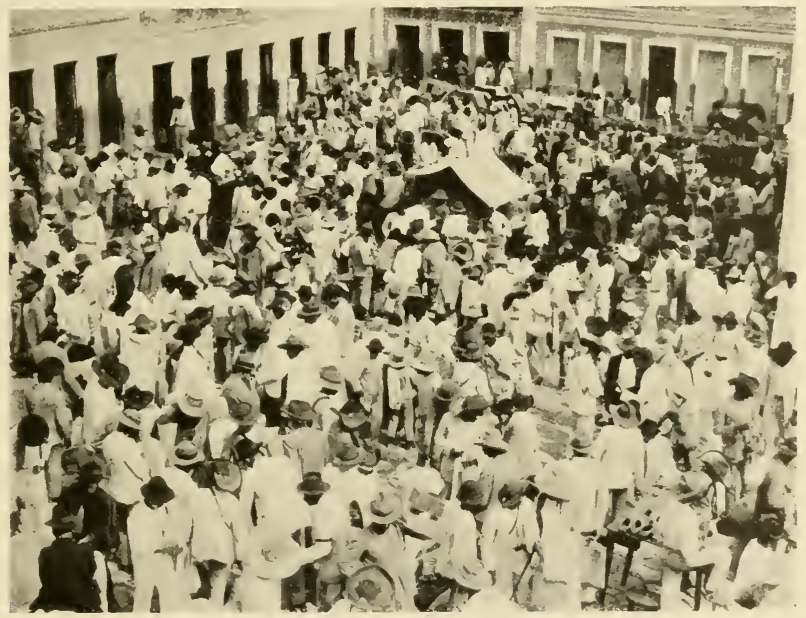

Market Scene at Sant'Anna do Ipanema

The export tax from the State of Alagôas is six per cent. ad valorem, plus seven per cent. Municipal duties are 200 reis per bale and in addition the large ginning factory we saw had to pay annually 1758000 for town dues.

The crop in Alagôas was not ready for picking at the time we visited the fields. The plants looked very vigorous: generally the "annual herbaceous " kinds remain two years in the field; "Verdão" remains four years.

One of our party went on horseback from Propria to Quebrangula, a three days' journey, and brought samples back from the following places on this tract:

(1) Propria.-Not in reach of overflow of São Francisco; cotton very dirty, most of it $23 \mathrm{~mm}$., but the "Verdão" is $30 \mathrm{~mm}$. 
(2) Propria.-In reach of flood water. Dirty sample; $22 \mathrm{~mm}$. ; very regular.

(3) Delta of SÃo Francisco.-About $23 \mathrm{~mm}$. This sample is not so even in length as Alagôas cotton generally.

(4) Olhos D'Acua do Acioli.-One gin with forty saws.

(5) Cururipé (Municipality of Palmeira dos Indios).-One gin with fifty saws always well sharpened. Length of staple $2.2 \mathrm{~mm}$.; pretty regular.

(6) Palmeira dos Indios And Quebrangula.-Sample contained much sand and leaf dirt; some eotton looked quite dark. The "Verdão" in this sample was on an average $24 \mathrm{~mm}$. ; a hybrid "Verdão" measured 3ðmm. and was silky. The "herbaceous" cotton had only $20 \mathrm{~mm}$.

(7) Quebrangula And Vicoza Zone.--The saws of the gin are regularly sharpened once in three months. The unginned "Verdão" measured $30 \mathrm{~mm}$., the saw-ginned "Verdão" only $25 \mathrm{~mm}$. There was a large percentage of "Verdão" in this sample and therefore it felt very soft. 


\section{Chapter IX.}

\section{STATE OF PERNAMBUCO}

Superficie: $99,896 \mathrm{sq} . \mathrm{km}$.

Population : $1,200,000$.

Capital: Recife (or Pernambuco), $240,000$.

Density of Population : 12 per sq. $\mathrm{km}$.

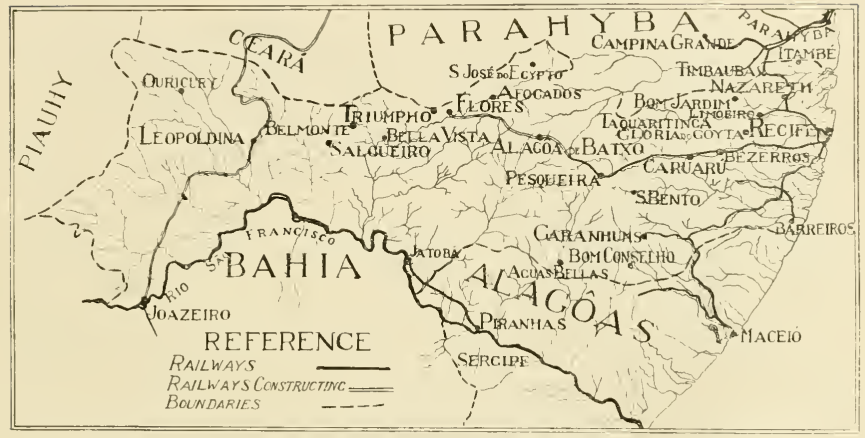

Map of Pernambuco

The State of Pernambuco is almost four times the size of Alagôas. It is situated north of Sergipe. In the west it has a long coast-line with Recife, as the city of Pernambuco is called, as an excellent port; in the north the States of Parahyba and Ceará are the boundaries and in the east Piauhy and Balia mark the frontiers. Recife is the nearest Brazilian port to Europe, being about 4,000 miles from England. "Recife" means "reef" and refers to the coral reef which forms almost a natural harbour in front of the city. This coral reef extends several thousands of miles northwards.

The State of Pernambuco is, and has been, the principal cotton exporting State of Brazil, due to the facilities which shipping affords and to the fact that in the city of Pernambuco several houses established themselves many years ago which made it their business to grade the cotton and to press it into bales of high density. ${ }^{*}$ Had it not been for this fact, the trade would have been diverted. for it is not that Pernambuco produces a large quantity of cotton. A very important quantity of cotton from Parahyba and other neighbouring States finds its way annually into Recife. Permambuco is principally given up to sugar, though the cotton crop is the second in importance.

* See Chapter xiii. for full description of method of handling cotton for export. 
The present Government seems anxious to devote more attention to sugar than to cotton.

Last year's crop (1920-21), grown in Pernambuco, according to the figures of the Cotton Department, amounted to $29,794,000$ kilos, the largest cotton supplying municipality being SÃo José do EGYPTO with three millions, then following Correntes, Flores, Timbaúba each with $2 \frac{1}{2}$ millions, Bom Jardim, Caruarú, Garanhums, Gloria do Goytá, Limoeiro do Norte, Nazareth, Afogados de Ingazeiro, Brejo da Madre de Deus, Taquaretinga, each with over one million kilos.

The State of Pernambuco has three cotton zones, viz. :

(1) North-east, served by the Great Western Railway with the lines of Limoeiro and Parahyba.

(2) The Centre, served by the Central de Pernambuco Railway where the best producing district is, with Barão do Rio Branco as terminus, which may be considered the collecting place of all the hinterland extending to Belmonte and Salgueiro.

(3) The South, Garanhums-Guapapá and part of the Alagôs Railway branch.

Cotton grown in the State and exported pays 5 per cent. tax but cotton brought in from neighbouring States does not pay export tax again on being shipped; such cotton has paid the tax in the State of origin.

Our first acquaintance with Pernambuco cotton was at GARANHUMs, which is 1,000 metres above sea-level. It is a most curious sight to see cotton fields, palm trees, European vegetables such as potatoes (not swect potatoes), cabbages, cauliflowers, apple and pear trees growing in fields close together. The elimate here, owing to the altitude, is quite temperate and bracing.

The mayor of the town took us in a car to show us the cotton fields in the neighbourhood. No effort is made to keep to one variety ; we explained to the farmers that they should keep their fields planted with only one variety.

There is a prospect of achieving some good results in this district, because Messrs. Trajano de Medeiros \& Co. have, at this town, an up-to-date ginning factory with 4 gins each 60 saws (see $p$. 174). This ginning plant has been working for two years; about 3,000 bales of 200 kilos are ginned every year and forwarded from here by rail to Recife (Pernambuco) a distance of 286 kilometres. Suction pipes convey the cotton to the gin and again to the double box press, which is eapable of turning out four bales per hour.

In the ginning factory is one of Howard \& Bullough's openers, in which ginned cotton is cleaned for clients on commission at the rate of 200 reis per kilo for cleaning and baling. This process enables the cotton to be put into a higher class, being much cleaner than before, but the cotton loses a good deal of its bloom, probably because it runs too fast.

This firm does not buy the cotton which it gins in its various establishments, but does the work of ginning and baling on commission. 
On the bales turned out by the hydraulic box press of this firm the railway company makes an abatement of 20 per eent. on the freight owing to the greater density.

This ginnery was established as a result of a eoncession granted by the State of Pernambuco, one of the eonditions being that pure seed for planting purposes must be supplied without charge to planters in the district and the firm has promised to distribute only one variety, viz., "Verdão." One of the employees of Trajano de Merleiros \& Co., Mr. Oscar Kriger Piquet, was with the Mission for the greater part of the tour.

At the time of our visit to Garanhums this firm was adding an extensive cotton seed oil mill to the ginnery.

The total output of the zone has been plaeed at 15,000 to 20,000 bales of 75 kilos per year.

The arroba of seed cotton in this distriet has 20 kilos.

Garanhums is the centre of what might be ealled the southern zone of Pernambuco's cotton districts; as we proeeed north the cotton becomes of longer staple.

We visited Limoeiro and here inspected another nodern ginning factory belonging to the "Soeiedade Algodoeira do Nordeste Brazileiro." It is on exactly the same lines as the faetory at Garanhums. It has four gins with 80 saws and is made by the Munger Huller Gin Co., Dallas, Texas. But there is here a box bale press of greater power (gin compress) turning out bales of 220 kilos $20 \mathrm{in}$. by $25 \mathrm{in}$. by $59 \mathrm{in}$. with an average density of $311 \mathrm{~b}$. per eubie foot. 40 bales are pressed daily and the railway companies make a eoneession on these bales of 40 per cent. and the steamship companies of 50 per eent. on the normal rates.

The ruling prices for first-class cotton here were $9 \$ 000$ per 25 kilos (one arroba $=25$ kilos here); second-elass 45500 . This is for fair quantities but $1 \$ 000$ less per arroba is paid for small lots. On an average the cotton which entered at this gin measured $24 \mathrm{~mm}$. to $26 \mathrm{~mm}$, but there were also the following, all mixed up :-

Moeó : up to $40 \mathrm{~mm}$, weak.

Verdão: from 30 to $35 \mathrm{~mm}$. strong.

Annual or Herbaceous: up to $20 / 22 \mathrm{~mm}$.

Quebradinho: up to $37 / 38 \mathrm{~mm}$.

The farmers are present when the classification is marle.

At another gimning factory in this little town were three gins with 35 saws; we noticed a delinting machine and found that a labourer was putting some linters into each bale of eotton. This is a distinet breach of the Cotton Proteetion Aet, but evidently the owner had acted in ignorance as he innocently told us that in one season when he had diseontinued this practice he had lost 30 contos.

The bales pressed at this second faetory weighed so to 90 kilos and measured $49 \mathrm{in}$. by $34 \mathrm{in}$. by $2 \mathrm{lin}$. The density was $19 \cdot 5 \mathrm{lb}$. per cubic foot.

We also visited Messrs. Trajano de Medeiro's ginning factories at CAETANo and at SAPÉ. They are up-to-date saw-gins but as some long staple eotton is entering these distriets, it is desirable that they 
should have some roller gins. There is no difference made in the speed of the gins whether the cotton is long or short. Long cotton, if ginned by saws, should be ginned slowly.

Barão do Rio Branco :

There are four gins and a press exactly as at Limoeira, belonging to the "Sociedade Algodoeira do Nordeste Brazileiro," whose head offices are at Recife, Pernambuco. The Rio Branco gin handles 28,000 bales of seed cotton of 75 kilos per year. They state that twothirds of their cotton comes from over the frontier, from Parahyba, and only one-third from Pernambuco. Ginned cotton is sent to Rio Branco from a distance of 60 to 70 leguas $(1$ legua $=5 \mathrm{~km}$.) and unginned cotton from 10 to 12 leguas away.

The "Verdão" cotton is here again the largest yielder, strong and silky. The usual mixture exists in the field.

Annual cotton is planted in February-March and as it matures within six months the cultivators prefer it to the tree cottons.

Annual cotton is mostly planted at "PEdra," "Brique" and "Aguas Bellas." The pink boll-worm is still attacking the "herbaceous" cotton here.

The ginning outturn is stated to be 26 per cent.

There are sufficient workers to be had at $2 \$ 000$ per day.

Seed cotton is sold here on the basis of 20 kilos $=1$ arroba, whilst lint cotton is sold at 15 kilos $=1$ arroba.

In this district a difference is made between clean and dirty cotton. The prices were $6 \$ 000,5 \$ 000$ and $4 \$ 000$ per 20 kilos according to the state of cleanliness.

Indian corn and beans are sown in the same field, along with cotton.

At Alagóa do Baixo we were shown what is supposed to be "Caravonica" cotton. It seemed hybridised with "Verdão" and the fibre had probably obtained its silkiness from the latter. The length was $40 \mathrm{~mm}$. but weak and the field was not pure.

"Verdão" was again described as the best. In this district what is locally termed "herbaceo" cotton is grown as an amual plant.

The transport expenses on muleback for two bales of 80 kilos to Barão do Pio Branco (the terminus of the railway) are 58000 . This rate varies according to the chances of having return freight, and it is very high when the country is suffering from a drought. It has been as low as 48000 but also as high as 118000 . The distance to Rio Branco is $60 \mathrm{~km}$.

At Alagôa do Baixo is a gin with 50 saws which are sharpened from two to four times a year.

Cotton fields are now much more frequent and as we proceed north the crop is in a more advanced state.

All the fields are enclosed with a wicker-work wattle-fence, the cost of which is here estimated to be $1 \$ 000$ per metre.

"Mocó" cotton begins to be grown here. The flowers are almost. canary-coloured and the bolls are small. 
The Federal Government has been constructing some excellent motor roads in the interior of this country, with the primary intention of being able to convey foodstuffs to the inhabitants during the periods of drought.

The whole of the north-eastern portion of Brazil is subject to periodical droughts which cause famine and widespread distress, but more will be said under this heading in the description of Rio Grande do Norte and Parahyba, which suffer more from them than the State of Pernambuco.

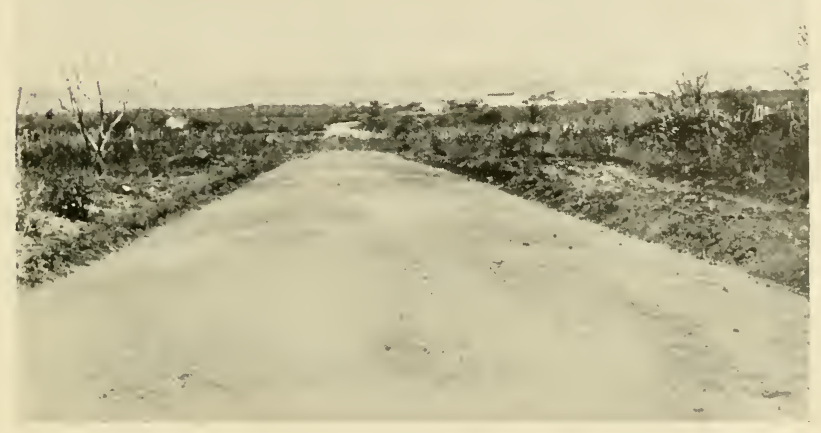

New Motor Roads of this kind are being constructed throughout the North-eastern States. This photograph was taken near Patos

The construction of these roads costs five contos per kilometre and whilst formerly all the cotton business was done at the coast, through the opening of these excellent means of communication the business, as we have seen in the case of Trajano de Medeiros \& Co., and "Sociedade Algodoeira do Nordeste Brazileiro," is being taken into the interior.

Besides the construction of these roads for the purpose of reducing the want of the people, the Federal Government has constructed large reservoirs of water in several parts and it is in the neighbourhood of these that cotton is frequently cultivated. 


\section{Chapter X.}

\section{THE STATES OF PARAHYBA AND RIO GRANDE DO NORTE}

These two States must be dealt with in one and the same ehapter, as the conditions in the two are so much alike.

\section{PARAHYBA}

Area $\quad . \quad \ldots 58,400 \mathrm{sq} . \mathrm{km}$. Population 600,000 inhabitants Capital : (Parahyba)

$\begin{array}{cc}\text { Density .. } \quad 35.000 \text { inhabitants } & 10,273 \text { per sq. } \mathrm{km} \text {. }\end{array}$
RIO GRANDE DO NORTE

Area $\quad \ldots \quad \ldots 41,246 \mathrm{sq} . \mathrm{km}$.

Population 410,000 inhabitants Capital : (Natal)

20,000 inhabitants Density .. 10,000 per sq. $\mathrm{km}$.

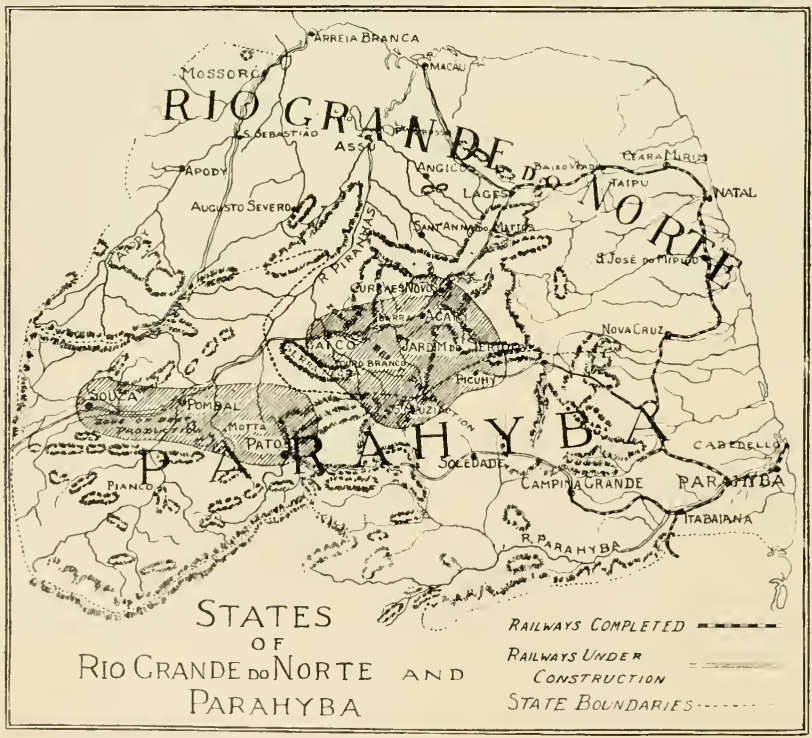

The two States are situated in the north-eastern corner, north of Pernambueo, the State of Ceará is the western boundary. The Atlantic Ocean, with Areia Branca (near Mossoró) and Natal as ports in Rio Grande do Norte, and Cabadello (near the city of Parahyba) in Parahyba, forms the eastern limit of the two States. 
The country rixes from the coast in four definer steps towarts the interior, viz :-

1.-Littoral or “ Agreste," extending from Pernambueo northwards along the eoast ; first it is some 30 miles broad but on the northern side its wilth may be 50 miles. It is more or less flat. The climate is not as himid as on the southern coast, nor as hot but it is much damper than up-eountry.

Cotton is grown here to a very small extent; on the east side only the annual herbaceous cotton is eultivated. In the market it is sold as "Matta." (On the northern side, near Mossoró, cottons of various kinds, as will be seen in the description of that district, are produced.

2. Matra zone.-These are the first hills. Various kinds of eacti are the characteristic. In dry places "Quebradinho" cotton grows, where it is damp the herbaceous mixture of hybrids will he planted. This is also elassed as "Matta" cotton.

3.-_ "CATINGUEIRA " zONE is again higher and being drier, the quantity of herbaceous cotton is less. "Quebradinho" predominates. More cactus grow, rocks begin to show and a few boulders are strewn about. A short kind of acacia tree grows here. Some of the cotton from here is sold as " Sertão," if long, and the inferior kind as Matta.

4.-- "SERTão" begins where a grass known as "CAPIM PANASCO," a coarse yellowish-brown grass, covers vast stretehes; this is the upper part, wild looking country, many boulders, one often balanced on the top of a heap): small brushwood ; triangular peaks of mountains of blue tint surrounding a plateau; the deep azure blue sky and the air most invigorating; eattle graze on the grass. There are fewer cacti here. Here is the cotton land, which gives the Sertano cotton, it grows along the valleys of the many rivers, or on low plateaus. Wherever one sees a plant, locally known as "Nalva," which has a vcllow flower, in formation similar to a Michaelmas daisy, cotton grows well, according to the saying of reputed farmer's, and certainly we have travelled days through stretches of this weed. The explanation of this saying is that cotton and this plant belong to the same botanical family. In this zone grow all kinds of cotton: "Verdão," "Inteiro," "Quebradinho," and "Mocó." Annual kinds are rare and should never be planted. This is tree cotton ground.

Unfortunately, owing to the high reputation which the genuine Seridi - Moco eotton enjoys in the market, efforts are made in all part: of the north to grow it, but it seems that Moco seldom turns out strong and long, exeept in the Serido district proper. of which more will be atid later. The cultivators would probably do much better in most parts if thev grew "Riqueza," (known in other parts as Verde). It is, of course, human to aim at the best, viz: Mocó. Riqueza is certainly second best and with seientific seed treatment might beat, in the lower Sertão, the Mocó plant.

Commercial Cotton Classification.-Seridó cotton and Sertão, first grade ("primciras"), are long staple cotton, grown on trees, they" are picked from July to January. "Matta" cotton is picked from September to February. The cotton merehants divide each of these 
three varieties into "first," or "primeiras," and "seconds" or "medianas" ; the lowest they call "refugo."

Droughts. - The rainfall of the whole of the north-east part of Brazil, from Ceará down to Pernambuco, even to the interior of Alagôas is very irregular, and at periods of between five and seven years there are seasons when no rain whatever falls. These periods of prolonged droughts used to be very fatal to the cattle and human beings and even now, though many water reservoirs ("açudes ") have been constructed the loss of cattle is very considerable. Grass, alfalfa and such other fodder crops which can be stored for long periods are not cultivated probably on account of the shortage of hands, but in some cases these crops could no doubt be grown and be used in times of droughts. From São Paulo northward we never saw a haystack such as we are accustomed to in Europe, North America, and even in Argentine. Would it be too much work or is there some other reason why hay is not made? When the rains do not come, then the people trek and walk hundreds of miles, from Ceará and also from the Sertão of the other north-eastern States, in search of water and food. It is then when the cactus tree is appreciated by the cattle, the juicy substance giving food and drink. Everything but Mocó cotton and the cactus dry up; indeed we have seen cactus cultivated by some farmers. It is mainly for the purpose of fighting these periodical droughts that the fine motor roads are being constructed. The Government also builds large reservoirs for the storing up of water, for these supply, besides drink, also food in the form of fish. Originally these reservoirs were built also with the intention of irrigating fields, but none of the many reservoirs I have seen was or could be applied for such purpose. As soon as the rains fall, the people return to their old homes; they love their native heath regardless of these droughts.

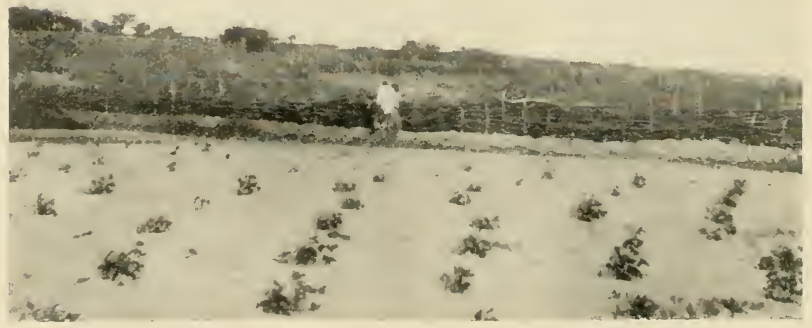

River-Bed Cultivation

As soon as the river dries up, beans and other vegetables are planted. Note also the wattle-fencing 
Even in normal times the rivers soon empty themselves and for quite six months the river beds are dry and are used for the cultivation of beans and other vegetables. It is by digging holes into the river bed that many villages proeure their only drinking water supply, even in ordinary seasons.

The years of great droughts are long remembered; it is perhaps due to the hardships suffered by the inhabitants of these districts during famine periods that they are generally a hardened race, strong, and frugal by habit, though somewhat indolent, but when put to it, they can work.

The following were the years of "Grande Secca," as the droughts are called: $187778,1898,1905,1908,1915,1919$, and the years of very heavy rains were: 1882, $1888,1894,1899,1910$ to 1914,1917 and 1921. In these years as much as $1,500 \mathrm{~mm}$. rain fell. During the normal season the rainfall is about $600 \mathrm{~mm}$.; when he gets that quantity of rain, in about three falls, the "sertanejo" (name of the inhabitants of the Sertão, or upland) is quite satisfied.

The rains generally cease about the beginning of June, but unfortunately for the first growth of cotton this year they started again in July. Our journey was made slower in consequence of the rains; it was intended that we should travel through these States by motor car, but once off the main roads this mode of travel became impossible, the cars would not cover more than a few miles a day, as we had to spend hours in lifting and pushing them out of holes and muddy places.

The greatest difficulty was encountered when crossing rivers, as bridges do not exist. The following illustration shows one of the several crossings of river beds which were unexpectedly filled with water owing to the late rains. Finally we had to abandon the cars and take to horses, a much quicker way of travel than by motor in muddy country with no roads or only an old worn-out road, covered with grass, "malvas" and even brushwood. Through travelling on

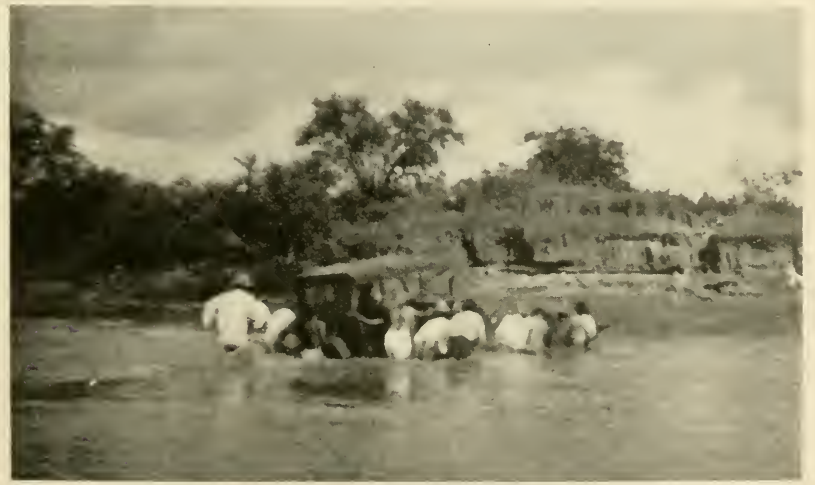

Crossing the River under Difficulties 


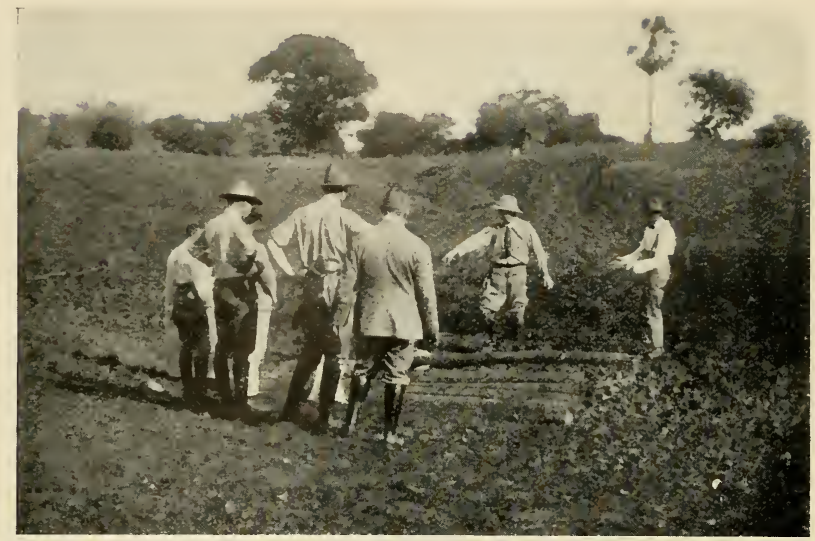

Road Difficulties. Constructing a Bridge for the Motor-cars

horseback we saw the country thoroughly; indeed, as the cotton grows mainly in narrow valleys, one can inspect the plantations only by riding a horse or a mule. In this way we travelled through the famous Seridó district, riding along valley after valley.

The method of cultivation is very primitive. In these undulating stretches of country, where rocks frequently come to the surface, the use of ploughs is out of question, consequently the "enxada" or hoe is the only possible agricultural implement used, just as it was hundreds of years ago.

As in most parts of Brazil, cotton is here also cultivated as a mixed crop. If ever this system can be excused it is here, where many empty patches exist due to the dying off of a tree. Indian corn, beans, melons, are planted here and wherever there is space. This compels the farmers to prune back the cotton trees, which is very good.

The cotton plantations being along the margins of the river bed in the Sertão, many get alluvial deposits from the flood water; no manure is applied anywhere. The life of a cotton tree is an uncertain quantity. Some trees were pointed out as being 40 years old and they were still bearing, but the general impression is that 15 years is the limit they ought to be allowed in the field. Trees are pruned back. The branches of the trees often bend down under the weight of the cotton.

Moco seed which produces the best Sertão and Sericló cotton is at times black, at others brownish; it has a distinet spike with twoended fork. The name Mocó comes from a small rodent of the same name larger than a rat but similar in shape, living in the mountains. The excrements of this animal are like the seeds of the Mocó cotton tree. Mocó seed has a spike with a two ended fork, sometimes it is brown, 


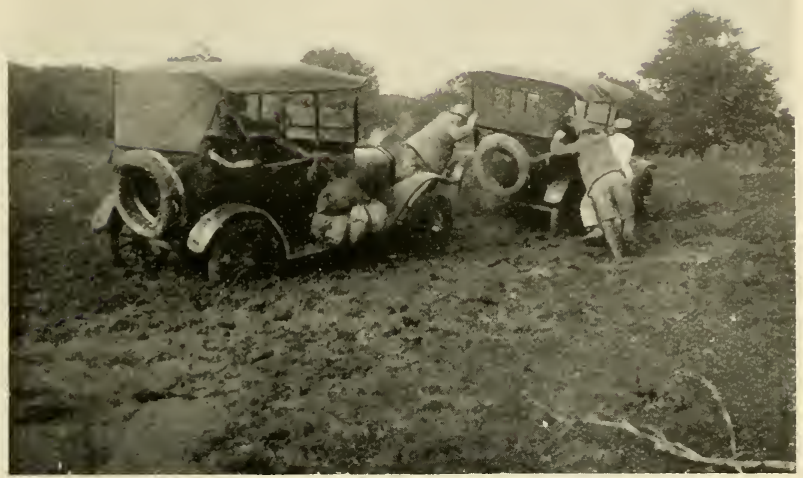

Road Difficulties with the Cars

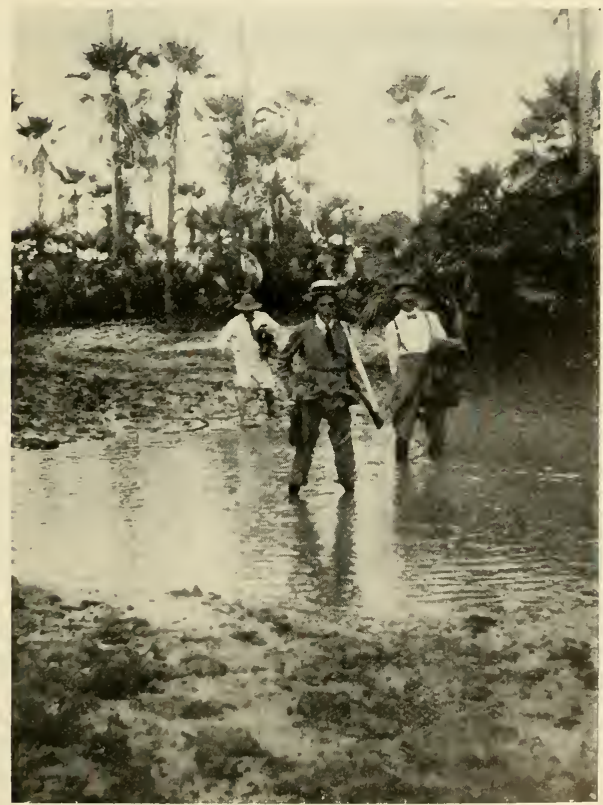

Difficulties of Travel. Motor-cars refused to travel through this mud. 


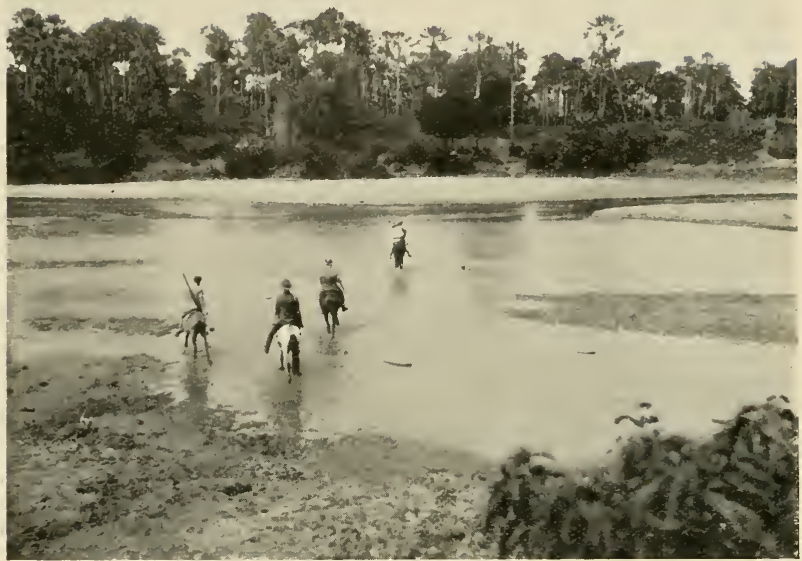

The Cotton Mission fording a River in Rio Grande do Norte

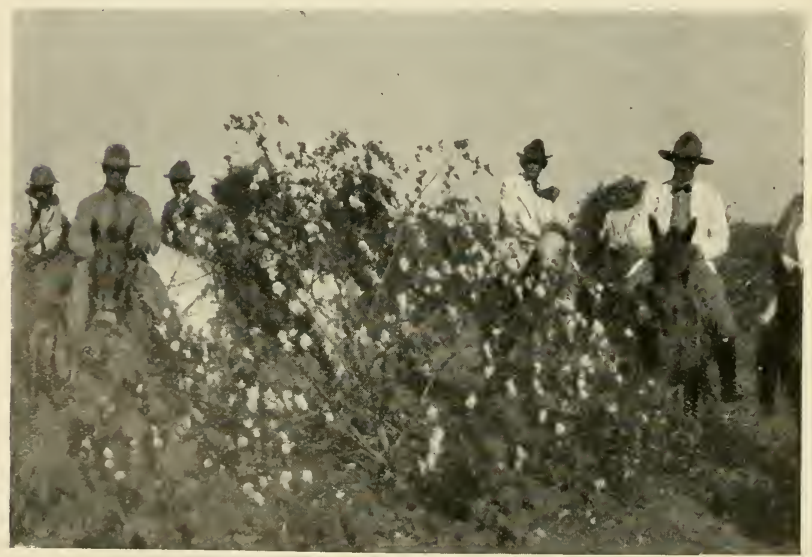

A typical Mocó Cotton Tree in the Seridó District 
but mostly black. Hybridisation has too evidently taken place, the original naked seed is often partially covered with hairs and the leaf of the genuine plant has short lobes, whilst many plants have long lobes, said to be a sure sign of crossing. The flower is of a lemon-yellow and the bolls are small, 7 to 15 being strung up at the ends of the branches, thus weighing them down. The plants bear from July to January. The average vield is difficult to assess, as the plantations extend in irregular wilths along the valleys of rivers and brooks, but after very careful calculation and allowing 50lb. an acre for over estimates we come to the conclusion that 450 to $480 \mathrm{lb}$. lint is on the safe sicle for the Seridó. Of course, catch crops such as Indian corn and beans are at the same time in the field.

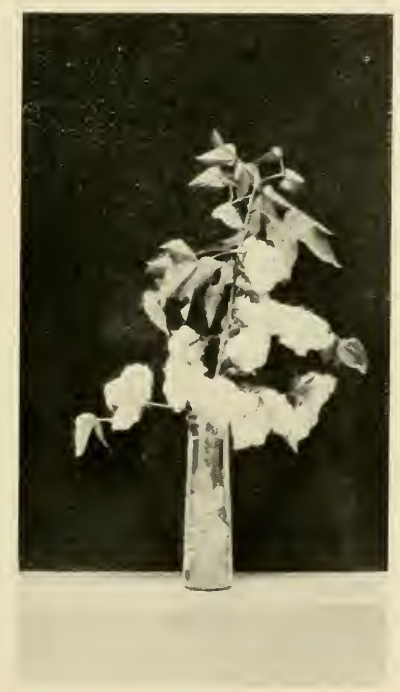

Mocó Cotton

There is also a very small seed variety of Mocó, to which is given the diminutive name of "Mocozinho" ; its fibre is perhaps slightly finer than Mocó proper.

Mocó cotton ripens all together and if the ground has sufficient moisture after the first picking which takes place in July, new leaves and bolls form which are ready by september and later. It is maintained that Moco trees get their moistiure by infiltration from the reservoirs, and by capillary attraction from the subsoil water which is not very deep.

General Remarks.-After the cotton has been picked the cows are allowed into the fields; the farmers have a saying that cows $\therefore$ salubrisam" (lit. they make healthy) the eotton, because they prune 
the branches, cutting them off clean as with pruning shears, but goats (which are very numerous) do a great deal of damage because they pick out all the young shoots, they "desolham" the cotton, i.e., lit. they take out the eyes.

Insect pests are not as severe as one might imagine at first thought, seeing that the trees provide shelter during winter; this absence of severe plagues is probably due to the intervening hill sides. There is only intermittant cultivation, as the crests of the hills are not cultivated; thus many miles separate one plantation from another.

The plantations are all carefully fenced by a wattle, of closer basket work than in Pernambuco. Cattle are grazing freely on the hills and therefore the fields have to be protected.

Picking is not performed as carefully as it ought to be, the people are apt to leave the cotton too long open ; it may be due to shortage of hands, but I noticed that in Parahyba there were women engaged in the picking, whilst in Rio Grande do Norte, very few women were to be seen in the plantations. Indeed the cotton fields of Parahyba were picked clean at the same time that the neighbouring fields in Rio. Grande do Norte were covered with open cotton, much had been shed and pickers were rarely to be seen. Some of the Brazilians in our party stated that the "Parahybano" was always considered a more industrious man than his neighbour.

As regards the necessity of establishing roller-gins in place of the old "Eagle" saw-gins, I have written in detail in Chapter iii. Suffice it to say here, that such an innovation would mean an increase of at least 25 per cent. on the value of the total crop, as the fibres would be longer and the grade would be improved. There ought to be nothing but roller gins in the Seridó.

In these general remarks I must mention the open-handed hospitality of the people. Wherever one arrives at night, even without. previous notice, one is heartily welcomed. The best of the food which the "Sertanejo" has is put before the stranger and sleeping accommodation is found. They are very kind people. In these parts everybody uses a hammock instead of a bed, a very convenient and comfortable substitute, always free from insects, which is a great advantage over a bed in tropical countries. During the day the hammock serves as saddle blanket. In each farm there is generally a large room, walls are mostly uncovered clay, carnauba palm trunks hold up the structure and in every upright beam there are found hooks for fastening up the hammocks. Two or three hammocks may be tied to one hook, spreading out at different angles, thus many people can be accommodated in a comparatively small space.

Life in the "Sertão" is quite safe now ; until recently this has not always been the case, and the old farm houses have still loop-holes. for the rifles, indeed they are constructed like a small fortress.

There is a distinct desire on the part of many cultivators in these parts to use selected seed for planting, several complained that they could not obtain pure strains. The people realize the advantages they can obtain from good seed. Some cultivators we met were selecting the best plants in their fields with a view to preserving the seed for planting purposes. 
There are large landowners and small eultivators, the latter working generally on the share system.

Further details will be found in the following notes taken from my diary, which describe the route we followed and the points of interest :-

From Recife we travelled in a special train to Parahyba and Natal, where we had long interviews with the Presidents of the States and with the cotton exporters, of which particulars are given in Chapter xi.

From Natal we had a special train to LAcies, taking with us two Ford motor cars, the only kind which ean be used in a country of this nature. We stopped on the way at BAIXA VERDE, in the municipality of Taipú, to inspect a cotton store and a cotton field. In the former we saw for the first and last time during our tour that a person was employed in separating the damaged and matted fibres (called "crueiras") ont of a heap of cotton. In the cotton field there was a mixture of all kinds, but one Mocó tree which had a strong fibre of $45 \mathrm{~mm}$. occupied our interest. The farmer had not taken the trouble to thin out, there were 12 trees growing in one hole.

Two German commercial men whom we met at Natal had been eultivating cotton during the war in this neighbourhood. They were very satisfied with their experiment. They gave us the following information as regards their own experience :-

"RiquezA" (same as Verdão) was $28 \mathrm{~mm}$. long, yielded $180 \mathrm{lb}$. per acre with nothing else but eotton in the field. Ginning out-turn : 28 per cent. Little damage done by pink boll-worm.

"Webber" American Upland, pure, was 3:2 $33 \mathrm{~mm}$. long and yielded $3001 \mathrm{~b}$. per acre, it being elosely planted.

"Quebradinho" (small black seed) in the first year gave hardly anything, but in the second year there was a plentiful erop. Length, $28 / 30 \mathrm{~mm}$, ginning out-turn, $27 / 28$ per cent.

Annual, or locally termed " herbaceo," i.e., aeclimatized American, length, $2 \cdot 2,24 \mathrm{~mm}$. ; ginning out-turn, $25 / 26$ per cent.

Share system with 50 per cent. to landowner in lieu of rent is general, but some small cultivators rent their land. Only the hoe is used.

The value of land was stated as about 350 milreis per 100 square $\mathrm{km}$. There is a shortage of water.

LAGES is the terminus of the railway. Some 20,000 bales of 70 kilos pass through every year ; it is a smaller market than Campina Grande, but of importance. We visited a farm close by called "BELLo Horizonte." Riqueza proved to be the best of the mixture, being at times $35 \mathrm{~mm}$. long. Mocó cotton was found to be very weak, and many dead fibres were in the lot we saw.

Cotton seed was being sold at 4 milreis per 20 kilos.

The railway freight from Lages to Natal is $2 \$ 300$ per bale of 75 kilos cotton. 
A ginner complained that it would be too hard work to separate the green Riqueza seed from the pile of mixed seeds in his factory. It is indeed easy work for a ehild. (In 1905-06 the Khedivial Agricultural Society eleared out in this way what is known in Egypt as "Hindi" cotton.) A 12 h.p. Blackstone Oil Engine was driving a 50 blade saw-gin.

The Mocó-fibre before ginning measured $45 \mathrm{~mm}$, after ginning it had only $37 / 38 \mathrm{~mm}$.

We motored to "FAzenda JoAzerro," in the municipality of Sant'Anna do Matto. A windmill was driving the gin; the speed varying has, of course, a detrimental effect.

The Federal Government Cotton Department had here a nice demonstration field with Moeó cotton. The trees were planted $1 \frac{1}{2}$ by $1 \frac{1}{2} \mathrm{yd}$. apart, but in the seeond year they intend to remove every other row.

We picked from one and the same branch black Mocó seeds and brown ones.

We saw here the first eultivation of a dry niver bed. As soon as the water reedes the people owning the land on the banks plant in the river bed beans. They even use stable-manure in this kind of eultivation and erect fences to protect the erops from the cattle. In consequenee of the reeommencement of the rains a great deal of damage was done this vear, as the river beds filled with water again and earried away the recently planted erops. This kind of eultivation is ealled "varzea."

The rates of a mule-load are 4 to 5 milreis to Lages and 8 to Angicos.

At a farm ealled "SÃo BENTo," the owner told us that the yield was about 2501b. lint cotton per acre over an area of 30 acres. His Moeó eotton measured $40 \mathrm{~mm}$., but was weak, the Riqueza, though only $32 \mathrm{~mm}$., was very strong and silky.

Our next stop was at Axaicos $(10,000$ inhabitants) where the Prefect ealled a meeting of the eultivators; he explained the various points at issue and we had afterwards a good discussion.

The production of this district is about 14,000 bales (70 kilos) per year.

A " earga" (whieh is a mule-load of two bales) to Lages costs from here six milreis.

Mocó measured 40 to $42 \mathrm{~mm}$., Riqueza $35 \mathrm{~mm}$. and Herbaceous. $32 \mathrm{~mm}$.

Moco sheds the cotton very easily. Riqueza in this district is more attacked by insects than Hocó.

A field of Moeó gave a yield of $462 \mathrm{lb}$. lint per acre; ginning percentage $3: 3$ per eent.

There are 14 ginneries in the district. An exporter who has an agent here made last vear a difference of three milreis per arroba of 20 kilos seed cotton between clean and dirty pieked cotton. This agent works on a commission reeeiving one milreis for every 100 milheis cotton purchased for the exporter, the latter finds all the ready eash.

Iloco is very easily ginned; its price, if pure, is higher than ordinary cotton. 
A seed farm in this district would be a boon, as the cultivators are very intelligent and complain of lack of good seed.

In consequence of the bad state of roads our progress by car was very slow. The Mayor of Assú and several Government engineers, knowing that we had to cross the river " Assú," whose bed, 800 metres wide, had been filled with water owing to the rains, assisted our crossing. Some 20 men pushed the motor cars through the water.

We inspected at Assí a ginning factory where both Mocó and Riqueza (here called "Azul ") was $30 \mathrm{~mm}$. in length. Nocó was weak.

The present price is three milreis for 20 kilos clean seed cotton and two milreis for dirty cotton, including dead fibres.

The ginning percentage of Riqueza was given as 25 per cent., the yield as 505lb. per acre. This high yield was obtained on land subject to inundation in the neighbourhood of Assú, at a farm called SÃo ANTONIO.

Three great irrigation schemes in this district are contemplated: one at PATA CHOCA, for which the eontract has already been given to Messrs. C. H. Walker \& Co. Ltd., London. This firm does a great deal of constructional work for the Brazilian Government, receiving 15 per cent. commission on all outlays. A reservoir to contain 150 millions cubic metres water is to be constructed. At Mudubim and LAciôA DE Piato dams for 50 millions and 25 millions cubic metres water are under consideration.

At Assú we had an excellent meeting with the cultivators of the district. It being market day a large number of them were in the town and the Mayor invited them to the town hall, where after an address by the Mayor, who is himself interested in the cotton business, we had a lively and interesting discussion. One farmer stated that on his "fazenda Camello" he had obtained from selected Mocó 500lb. lint per acre in the first year and over 700lb. the second year.

The farmers calculate the yield in this district per 1,000 holes (" covas"), which is equal to 3,025 square metres.

On the boundary road between the municipalities of Assú and Mossoró, the Mayor of the latter town, Mr. Camillo Figueredo, who is a merchant of Mossoró, dealing also in cotton, met us. We had to cross the river UPANEMA, a tributary of the Assú, under similar diffieulties to those we had experienced previously.

We visited the mayor's cotton plantation and another one, called "BoA Vista" and "Buenos Aires."

There was the usual mixture, but Riqueza predominated with a fibre up to $35 \mathrm{~mm}$. The cotton is pruned back generally only when Indian corn is to be planted between the cotton. There were Mocó trees with branches weighter down; they spread out like fern leaves. 10 to 14 sets of bolls were at the end of the branches. The fil:re was $42 \mathrm{~mm}$. long.

Mossonó has only lately taken up cotton growing, but there seems every chance of success, as the yield in the first year on one plantation was 280lb. lint per acre, in the second $300 \mathrm{lb}$. and this year, the third, they thought the crop would be much bigger. 
A piece of land $1,540 \mathrm{~mm}$. frontage to the river and $5 \mathrm{~km}$. in depth was recently sold at 3 eontos. The frontage to the river is the deciding factor in land purchases in these parts, as the crops depend to a great extent on the inundation which yearly deposits silt.

Some 40,000 bales pass annually through Mossoró, concentrating there from the Seridó, Parahyba and Ceará. The distance from Mossoró to Limoeira (in Ceará) is only $90 \mathrm{~km}$. of a good road.

An excellent sample of eotton, uniform, $50 \mathrm{~mm}$. in length, coming from the JAGUARIBE valley in Ceará was shown to me. Dr. W. L. Balls in his report signals these samples out as being high-class. (See Chapter xii.) Russos in that valley is an important cotton district.

There are in Mos:oró several important merchants, who deal in all kinds of produee, but especially eotton, earnauba wax and goat skins, viz. :-

II. F. de Monte \& Co. ship bales of 120 kilos to Europe, their agents in Europe being Jacob Walter \& Co., London, and J. Bromley Moore \& Co., Liverpool.

Tertuliano Fernandes \& Co., Mossoró, have bought recently a high density press, from Ceará, which will turn out bales of 150 kilos.

Other Mossoró eotton merchants are :

Alfredo Fernandes.

Camillo Figueiredo.

F. Borges de Andrade.

João Fereira de Almeida.

These firms issued broadeast a circular explaining the neeessity of clean picking, etc. We saw this eircular plaearded up in many shops of the interior.

In ARACATr, the port of shipment for the produee of the Jaguariba valley, there are :

J. Klein, Figueredo \& Co.

Costa Lima \& Mirtyl.

The port for Mossoró is Arreia Branca ; for an ox-eart carrying 18 bales each 70 kilos to São Antonio and from there in lighters to the ocean steamer costs at present about 800 reis per bale, the same priee as is eharged by the railway company.

Our next stops were at São Sebastião, Pedras das Abelhas and Brejo Do Apody. Very little eotton was to be seen; the few fields represented a mixture in which Verdão was always the best, measuring up to $32 \mathrm{~mm}$. This is really the Carnauba Palm district.

At Carahubas the Verdão cotton is known under another new name "Pelucho." At a press in this place they moistened the sides to improve baling. Buyers complain that the cotton from here eontains a good deal of sand.

Fraudulent Packing.-Seridó merchants eome here to buy inferior Mattá cotton, take it to Seridó and have it rebaled in saeks of 64 kilos. (At Carahubas the bales are mostly 100 kilos as they use oxen carts for transportation.) This Mattá eotton is afterwards brought into the market as Serido eotton. (Just what they did in Egypt, when they mixed Upper and Lower Egyptian cotton.) 
Our next stop was at the FAzEnd Fortuna, 140 metres above sea-level. This is the first spot where we find strong Mocó cotton; Verdão does not do well, but a variety which looked as if it might be a hybrid between the Inteiro crossed with Mocó, was good, being 38 to $40 \mathrm{~mm}$. and strong. Moco gives the best yield out of the mixture of Herbaceous, Verdão and afore-mentioned hybrid.

At Uruguayana Mocó was not as good as in the last place. We halted at Augusto Severo, 130 metres above sea-level; this town was known as "Campo Grande " and before that as "Triumpho." There are 7 ginning factories in the township each with hand-presses; half the cotton is sent to Lages and half to Mossoró, to the former town the rate for a mule-load is 12 milreis, to the latter 6 to $8.2,000$ bales are handled annually. The price of cotton in Augusto Severo was $2 \$ 500$ for 16 kilos seed cotton, ginning out-turn 33 per cent.

In Colonia the farmer was in the habit of separating the seed for planting purposes; the same is done by the owner of CACHOEIRA.

At SÃo AnTonio where we see the first "açude," a reservoir $6 \mathrm{~km}$. long and $1 \mathrm{~km}$. wide, Verdão and Herbaceous do well in land subject to flood. They plant in June-July and within four months the crop is ready. The intention is to raise the dam of the "açude" by six metres which would enable 500 hectares to be irrigated twice a month.

The Verdão in the district measured $35 \mathrm{~mm}$. and some Mocó cotton reached $37 \mathrm{~mm}$. It was strong cotton.

We passed on our way "Maracanahú," "Amazonas, Mulungú (Parahyba), "Catingueira." Mocó is mostly $35 \mathrm{~mm}$., at times $42 \mathrm{~mm}$. Herbaceous is only $22 \mathrm{~mm}$. It is a great pity that this latter should be allowed in so near proximity to the real Serido district. We could see distinctly the hybridisation that had taken place, the Mocó having taken on the roughness of the herbaceous cotton.

At night we had to cross the "Rio de Piranhas," which had so much water that the horses refused to swim with the riders in the saddle. We had to swim through the river leading our horses behind us.

At S̃̃o Fernando, which is only $15 \mathrm{~km}$. from Caico, Mocó cotton was again hybrirlised, measuring barely $35 \mathrm{~mm}$. and being rough. Verdão had the same length, strong and silky.

Mocó gives here hardly any crop during the first year, in the second year a tree yields from 8 to 10 kilos seed cotton, increasing every year until 16 to 20 kilos are reached. The ginning out-turn was 28 to 29 per cent.

Verdão gives a crop in the first year, in the second year it yields slightly less than Mocó, but after the third year there is hardly any crop. There is no pruning done. Mocó trees last here 10 years, but after the fourth year the plants are cut back close to the soil.

During years of drought the quantity of cotton per Mocó tree is reduced, but the quality is said to remain good.

No difference is made in price for length or resistance of fibre; the largest buyer paid at the time of our visit 4 milreis per 16 kilos for first, 500 reis less for second and $1 \$ 500$ less for third grade. 
Here are generally large landowners, who let the land to tenants on the understanding that 50 per cent. of the cotton crop is paid "in lieu " of rent. The tenant cultivates two rows of Indian corn between each row of cotton. When the landlords advance money to the tenants they pay 500 reis per kilo seed cotton less than the market price for cash.

All landowners have ginning plants and deal in cotton.

\section{S E R I D O}

The SERIDó proper is defined by the six following municipalities and only cotton coming from there should be sold as "Seridó" ; cotton from the neighbouring districts should be termed "type Seridó" :-

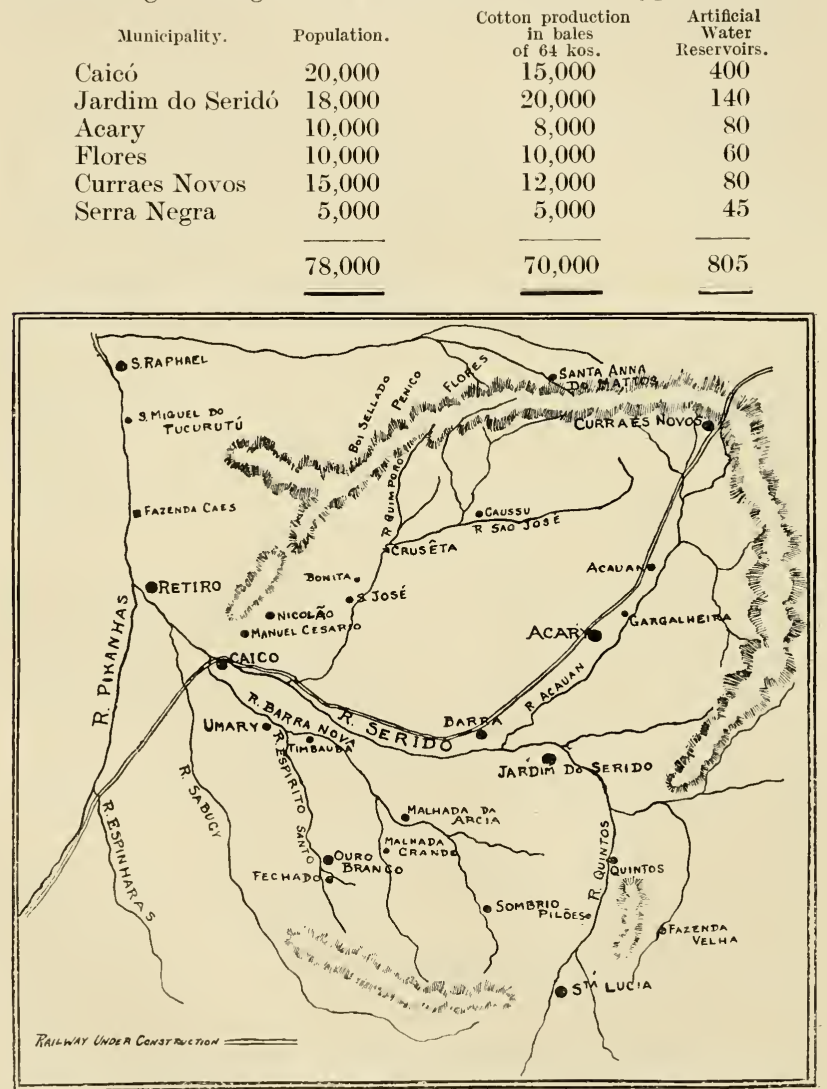

Sketch Map of the Seridó 


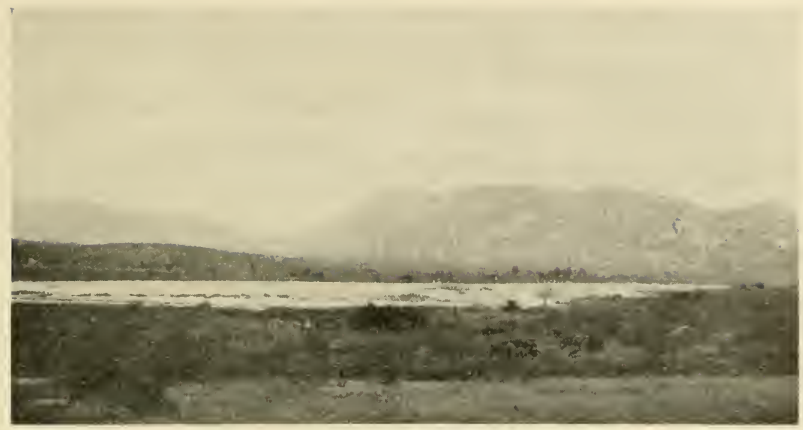

One of the many Reservoirs (açudes) in the Seridó District

Reservoirs.-In the municipality of Caicó there are 400 water reservoirs constructed by building a dam across two hillsides. This includes small and large ones. In 1909 there were in the whole of Rio Grande do Norte 1,086 reservoirs, of which the Seridó accounted for 700 . Since then this figure has risen to 1,500 , of which over 800 are in the Scricló.

Most of these have been constructed by the landowners, but the Government is at the present time building various reservoirs of large dimensions, with the ulterior object of irrigating the country lying behind. Whether it will be possible to undertake the irrigation of such very undulating country as this without expending further very large sums indeed, I doubt. In some cases the erection of the dams necessitates the flooding of large areas of fertile lands and it seems doubtful, indeed, whether the irrigation will be a commercial proposition and a technical possibility. Of course, the very sight of a sheet

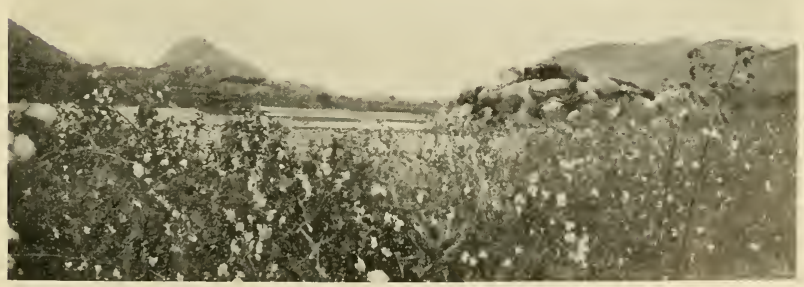

Typical Cotton Land in the Seridó District 
of water to one coming from a famine district is a great consolation, but judging from the lie of the land behind the three irrigation works visited, it would appear to me that great areas of first-class land are being sacrificed at the expense of a very problematical scheme which will require much larger sums than the construction of the dams has cost.

The Mocó cotton is the only plant in the Serido which will withstand the great droughts; this is probably due to the geological conditions of the valleys. Slanting rocks, forming an acute angle, on which there are layers of shingle and soil, seem to prevent the moisture from

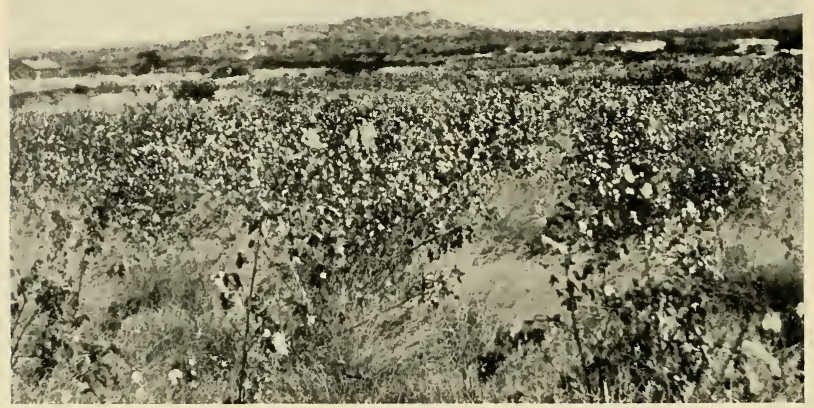

A Mocó Cotton Field on "taboleira" land

The dry grass "capim panasco" prevents the fallen cotton from beconing dirty

running off entirely. Evidently the deep roots of the trees find little pockets of soil and shingle which remain damp even during the years when no rain falls. Until quite recently cotton was grown on the margins of the rivers, brooks, etc., only so far up the slanting side of the hill from the course, as it was thought that the roots would reach into the subsoil water level. These lands are called "Baixos," i.e. low lands. But a few years ago some cultivators made experiments with growing cotton much further up the slant, on what are called "taboleiras," which used to be considered too dry. These experiments have been a great success, and the practice of using these "taboleiras " for cotton is becoming common. It is true that " taboleira" land does not give so big a yield, but the cotton is stronger. By bringing the "taboleira" land under cotton cultivation a considerable extension of the crop can take place.

One farmer planted his cotton in large holes, about a meter in circumference, thus forming a cavity into which the rain settled. This man had an excellent crop. 
Scarcity of Labour. - There are thousands of acres of this kind of land which have not yet been put under eultivation in the Seridó district. There is therefore every possibility of extension but the country suffers from a shortage of people, especially now since the Government has started the construction of the motor roads. Labour, which used to come to the Seridó from the Breijo sugar district of Parahyba, after the termination of the sugar crop there, in order to help with cotton picking in the Serido, has been attacked by the roadmaking firms, where discipline is perhaps not as strict as on the farms. Now that the rubber collecting in the Amazonas is being discontinued, it is to be hoped that the Cearense labourers who used to perform this work will be directed to the cotton fields of the Seridó, where the elimate is invigorating and living healthy.

No other crop but cotton can come into consideration in these quarters. Of Indian corn, beans, ete., only so much is grown as is required for the feeding of the inhabitants and their stock of pigs.

The cultivators whom we interrogated were mostly alive to the importance of pure seed; their only regret was that they could not obtain selected seed from anv institution and it is to be hoped the Government will undertake a Ilocó seed farm in this area.

We had the advantage of an excellent guide in the whole of the Seridó. Dr. I inacio Joaquim de Carvalho Filho, the chief judge of Caicó, who knows the whole zone thoroughly and who understands the peculiarities of the country, accompanied us throughout this part of Rio Grande do Norte, explaining the conditions and organising excellently the whole trip. We are much indebted to this gentleman.

We examined the gins in Caicó and found one with 50 saw-blades, though sharpened, which would not gin properly. The reason was that the man had ginned cotton that had become wet by the recent rains; the hairs had clogged the saw-points and consequently they would not work satisfactorily. We found quite a good lot of Mocó, silky, 35 to $38 \mathrm{~mm}$. long, but part was fully $45 \mathrm{~mm}$. before ginning.

The present prices for such cotton were four milreis per 15 kilos first-class seed cotton, and $3 \$ 600$ for seconds. One merchant told us that a large exporter had bought cotton in February/March, i.e., when the cotton was not yet grown, at 200 milreis per 130 kilos lint. free Lages station, charging one per cent. interest per month until delivery.

The cotton merchants in Caicó are :

Celso Dantas de Camboim ;

Ariston \& Cunha :

Gorgonio Ambr. da Nobrega ;

Luiz Agatangelo de Brito;

Fco. Gorg. da Nobrega.

Caico is situated on the "Rio do Serido," the main river; when it has water it runs so fast that the banks have to be protected by special grass. There is no cultivation of Baixos on this river on account of its quick flow.

On leaving the town we passed a small plantation where we saw $50 \mathrm{~mm}$. Mocó. We first visit the "Valle Do Saboeiro," 220 metres 
above sea level. Mocó was mostly strong, 35mm., but there is also Verdão, which is weak, though silky. This valley has 20 kilometres by 220 to 250 metres under cotton.

We cross the "Rio do Mundo Novo," the valley of which is $30 \mathrm{~km}$. in length, the whole of which is cultivated with cotton.

The plants were grown $2 \cdot 61$ metres apart both ways ( 12 palmas, each 22cm.). Besides Mocó a smaller seed, but otherwise identical with Mocó was planted. This small seeded cotton is ealled "Mocozinho " or "Sedinha," being silky in appearance.

Wages of labourers are 800 reis per day, but plain food to be found by employer; this is for picking. The farmer here had the system that one man was engaged to pick all the clean cotton and another followed the first picker to collect the dirty cotton left. In this way he got a premium of $1 \$ 500$ per 16 kilos on his clean cotton.

The land is sold in all these parts according to the frontage on the river or brook. At the time of our visit land changed hands at 50 milreis per "braça" $(=\mathbf{2} \cdot 20$ metres $)$ river frontage with $7 \frac{1}{2} \mathrm{~km}$. depth.

The fields in the Serido are frequently fenced in by stone walls.

The yield was given us as: low land, two kilos per plant; higher land, one kilo per plant; " taboleira" $200 / 300$ grammes per plant.

There is no need to clean "taboleiras" of grass; indeed, when the cotton sheds it falls on this "panasco" grass and does not become dirty. Taboleiras" have generally $1 \frac{1}{2}$ meter of a gravel soil layer on rock.

Fazenda São Nicolad is situated 240 metres above sea-level, in the valley of the São Nicolau, where it joins that of the river "Mundo Novo." The owner of the large fazenda was a very intelligent gentleman who had taken great interest in cotton.

He first showed us a specimen tree of the indigenous cotton growing wild in almost inaccessible parts on the heights of mountains between rocks. This cotton, called "Algodão Sylvestre " or "Ganga," was found there as long ago as 1807 at the time when the farm was bought, and has probably existed there for centuries. The seed is small and has a peculiar spike; some seed is bluish-green. The fibre is short and of little commercial value; its length was $20 \mathrm{~mm}$. From the historical, botanical point of view this plant is very interesting, as it is probably the forerunner of the Mocó or Verdão cottons found in Brazil.

The samples of "Mocó" cotton of this farm we considered weak. Of course, it must be taken into consideration that these samples are from the first pickings of the new crop which, according to general opinion in Brazil, is frequently weak, and latterly rains had been falling.

We rode for miles through the "Taboleira" portion of the plantation. There was a great deal of cotton ready for picking and beginning to shed. The owner was complaining of a shortage of hands, especially this year, owing to the employment given through the construction of roads. 
We came across one cotton tree, the fibres of which were $50 \mathrm{~mm}$. in length. This farmer is particular in seed selection: he plants "Mocó " as pure as he can get it. Absolutely pure "Mocó " is a thing of the past. Generally the bolls of "Mocó" are small, but the number of them on the branches is extremely large. We have seen as many as 15 bolls towards the end of a branch. "Verdão" and other kinds have only about four bolls at the end of a branch.

We rode through the VALLE DE S. José Do S'ERIDó to a village called Bonita ( 300 metres above sea-level). It was formerly called $\checkmark$. José do Seridó. In this rich valley, $55 \mathrm{~km}$. in length and 300 metres in width, all the low-lands (called "Baixos") were cultivated with "Mocó" cotton. From Bonita one gets a magnificent view of practically the whole of the "Serido" zone, surrounded by a vast amphitheatre of mountain ranges.

At Cruzêta the three rivers, Rio Quimporo, Riacho do Meio and Rio Do SAO Jos'E (or Salgado) meet.

At CRuzêta a huge water reservoir is in course of construction at a cost of 597 contos: it is expected to be finished in 1922. $16,000,000$ cubic metres of water will be stored there, and as the Government has acquired through appropriation extensive stretches of land, it is to be hoped that the Cotton Department will be allowed to establish a seed farm here. The cotton from this valley enjoys a good reputation. "Mocó" was pretty strong, but its length varied from $32 \mathrm{~mm}$. to $42 \mathrm{~mm}$.

The system of excellent roads begins again here and from Cruzêta to Natal huge motor cars, bringing material for the construction of the dam, travel regularly in eight hours.

We called at Fazenda Emburanas and later at Erinal in the municipality of AcARY. The owner of this farm, Mr. Francisco Paymundo de Aranjo, a plain "Sertanejo," has devoted more than ordinary attention to the cultivation of cotton. He has his own experimental grounds and keeps records of the behaviour of the plants ; he does scientific work by instinct. He assured us that an exceptionally large "Mocó" tree had given 3,065 bolls $=9 \cdot 45$ kilos seed cotton in the fifth year.

This farm had 25 hectares of "Mocó" cotton on "Taboleira" land and 9 hectares on "Baixo." On the "Taboleira" the yield of lint per acre worked out to 310 to $3201 \mathrm{~b}$. The trees were planted $1 \cdot 50$ by $2 \cdot 20$ metres. The trees last from 10 to 15 years. The first bolls open in June, but the main crop is in July to September and onwards to the end of the year and even January. This farmer had found water 10 metres below the surface and had endeavoured to trace the length of the roots, but had not succeeded; he had had roots two metres in lengths, but thought they must go deeper.

Mr. Raymundo was one of the first who used the "Taboleira" land for cotton. He plants his trees in January or February, when any re-planting is necessary.

Planting is undertaken at a time when there have been at least two falls of rain; he plants his seed in a hole, 12 inches lower than the surface, so that the water collects round the plants. Near the 
farm is one of the usual reservoirs, and no doubt the water from this filters through and supplies moisture to a portion of his crop.

This farmer has no need to take his crop to the market: the buyers come to his farm, and he always gets a premium over local rates.

The ginning outturn is now 26 per cent., but before the pink boll-worm eame it was 30 per cent. This farmer says that many farmers do not trouble to get back their own seed from the ginnery, and in some places, we are told, a man can take his seed cotton to the gin, receive at once the equivalent lint and seed of someone else's lot. As all cottons are alike in their estimation, such procedure saves time of waiting.

At this farm we saw 17 plants of Sea Island cotton growing as an experiment. The length of the fibre was from $50 \mathrm{~mm}$. to $55 \mathrm{~mm}$., strong, fine and silky.

I feel that the information obtained from Mr. Fco. Raymundo is quite reliable; this man made a very favourable impression on all of us.

Acary. This was our next stopping place and from there we visited the valley of the Rio Acauan. The town of Curraes Novos is situated on this river.

At Gargalheira, close to Acary, the river passes through a narrow valley which lends itself for the building of a dam, and here the Barragem Gargalheira is being constructed. Work is proceeding there under a contract with Messrs. C. H. Walker \& Co., Ltd., of London. It is intended to have the walls of the dam 25 metres high with three sluice gates. The top distance from one side to the other of the walls of the dam is 120 metres. It is estimated that 7,000 barrels of cement will be used. This reservoir is intended to be used for irrigation purposes, but from the nature of the undulating country behind each one of us felt doubtful whether this was a technical feasibility. Certainly tunnelling of many of the hills would be necessary to carry the water to irrigation canals.

At a farm on the way to our next halting place we were told that on "Taboleira " land "Mंocó " had yielded 282 kilos lint per acre, and "Riqueza" had given the same yield. The ginning out-turn was given as $28 \frac{1}{2}$ per cent.

We met another agent of one of the large cotton exporting firms who said he was paid two per cent. commission on the value of his purchases for the firm.

JARDIM do SERIDó (280 metres above sea-level). This little town is beautifully situated with a grove of tall palms at its entrance. It is probably the most important of the municipalities in the Sericlo district.

Mr. Felinto Elysio, the political chief of this town and a land owner, accompanied us through the rest of the Seridó. He showed us some very nice samples of his " Ilocó" cotton, $40 \mathrm{~mm}$. and strong. He makes a regular selection of seed and insists that all his pickers carry two bags, one for clean cotton and the other for dirty cotton and dead fibres. 


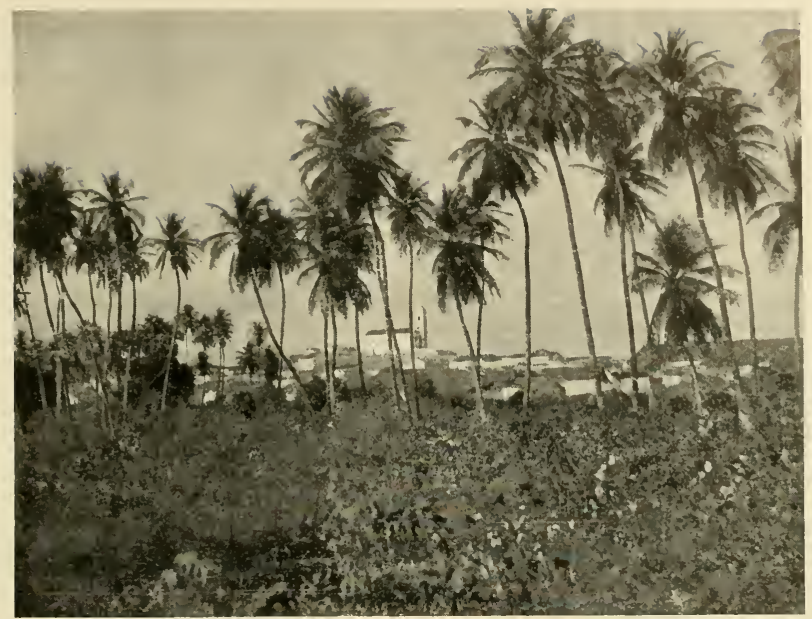

Jardim do Seridó, one of the principal Towns in the long staple district

We visited the estate of the Mayor, called Fazenda Apertado, where there is a large reservoir, constructed in 1874 . It is not intended for irrigation, but a small outlet has been provided to water the few fields cultivated with sugar.

The soil here evidently contains a great deal of saltpetre; this is especially the case near Malmada DA Areia in the valley of the Rio Barra Nova.

Another farm visited was Canto Alegre; the owner also selected his seed. His "Mocó" was up to $42 \mathrm{~mm}$. but somewhat weak.

At Malhada da Areia one export firm had offered this year $150 \$ 000$ per 120 kilos lint. To this must be added $10 \$ 000$ for transport to port.

UMARY. At this farm the cost of picking was $1 \$ 000$ to $1 \$ 200$ per 16 kilos, and one picker would collect daily an average of $801 \mathrm{~b}$. seed cotton. The length of fibre was $37 \mathrm{~mm}$. to $38 \mathrm{~mm}$.

Besides "Mocó" they grow "Mocozinho." It turned out slightly shorter but much silkier. 'The farmer considered "Verdão" more subject to insects than the other two kinds. Care is taken on this farm to separate dirty from clean cotton. We thought that the qualities were somewhat irregular.

Passing through Ouro Branco* we reached Fazenda I'olta do Espirito SANTo.

On the "Taboleiro" land of this estate some more excellent cotton was grown, averaging $38 \mathrm{~mm}$. to $40 \mathrm{~mm}$., but we found one tree

* Cotton is often called in Brazil "ouro branco," lit. white gold. 
with $50 \mathrm{~mm}$. to $55 \mathrm{~mm}$. and a very strong fibre. We thougint that this was the best cotton we had seen so far. The ginning outturn was 28 per cent. (See scientific examination of this cotton at end of this Chapter.)

SOMBRIo :

Mr. Felinto Elysio has a farm here and we saw a magnificent crop all along the valley of the Rio do CoITÉ. The yield in the previous year had worked out at $420 \mathrm{lb}$. per acre; half the land was taken up with Indian corn. For picking he pays $1 \$ 000$ per 16 kilos for clean picked (no food to be provided for the picker) and makes a reduction of 200 reis where the cotton is dirty. There is a gin with 35 saw blades on the farm. The price for ginning and baling on commission is $20 \$ 000$ to $22 \$ 000$ per " earga" of 128 kilos. (See end of this Chapter.)

Mr. Felinto separates the cotton seed he intends to use for sowing at once after ginning,

\section{Parelhas :}

Here again a reservoir is being constructed by the Government at Buquerão de Parelhas where the waters of the river Serido are to be collected. There is a catch basin of $18 \mathrm{~km}$. and $300,000,000$ cubic metres of water are said to be available. The cost is estimated to be 10,000 contos. The possibilities of irrigating the land immediately behind the dam seemed again a very difficult, if not impossible, task.

At the Fazenda VelHa situated at the bifureation of the Serido and Timbauba rivers we were able to obtain reliable information as to the yields. The low-lands give at least $450 \mathrm{lb}$. lint per acre.

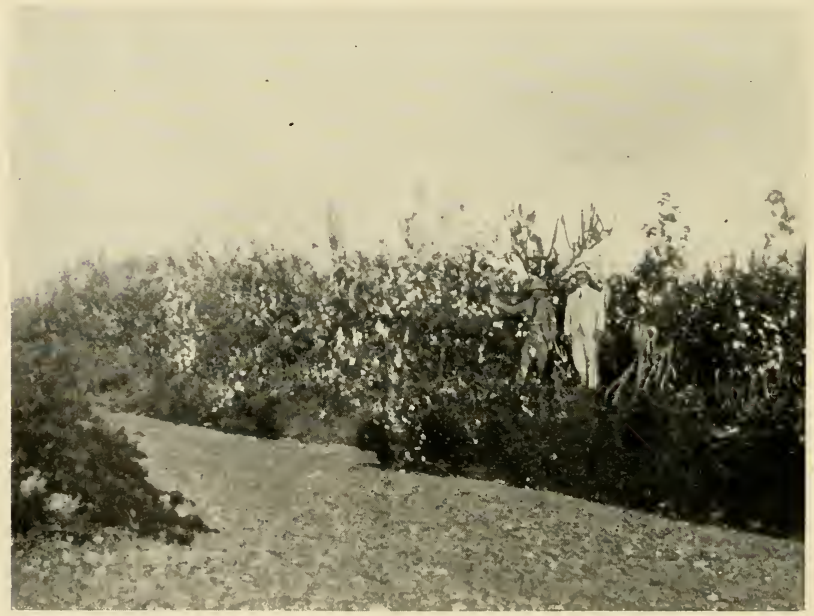

Mocó Cotton Cultivation along the Rio do Coité 
This farmer made a difference between sandy "Taboleiras" and stoney "Taboleiras." According to his opinion the latter produced excellent quality but a smaller quantity.

During the drought of 1919 the sandy "Taboleiras" gave no crop at all, but the stoney one yielded; he plants his trees four metres apart all round. This cultivator also selects his seed. After ginning, the fibres measured $36 \mathrm{~mm}$. to $37 \mathrm{~mm}$.

We noticed some of the khaki natural coloured cotton, viz., "Inteiro," in his fields.

This valley is 28 kilometres long, all planted with cotton.

At the Fazenda JoAzeiro we saw a pretty even cotton $38 \mathrm{~mm}$. ginned.

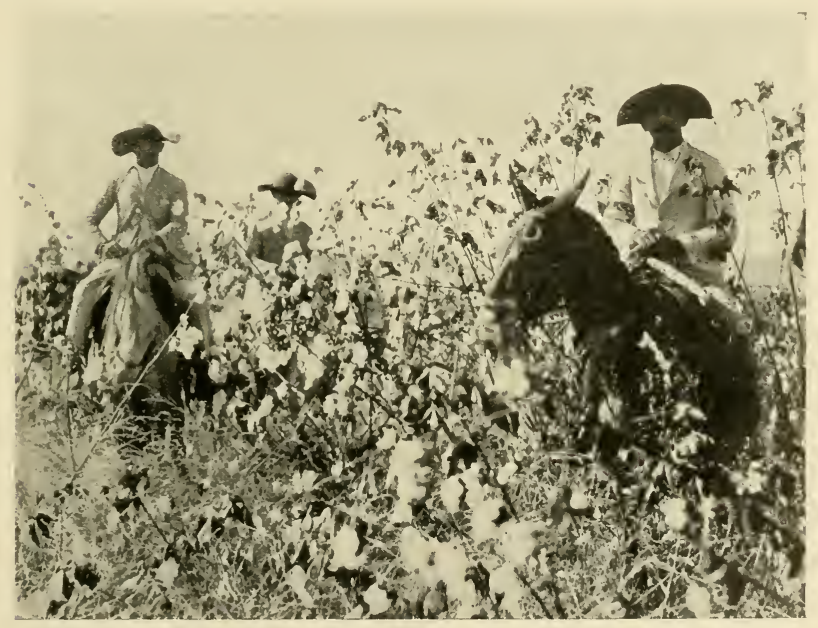

A Mocó Cotton Field in the Valley of São Bentos River, with Owners (Everybody here wears large leather hats)

"Seridó" cotton is generally a creamy colour and has a peculiar smell, somewhat like goats' skin. This year the first pickings have turned out quite white instead of ereamy.

The bales of 64 to 65 kilos measured $1 \cdot 25$ by $0 \cdot 75$ by $0 \cdot 40$ metres.

In the VALLE Do $\mathrm{S}$. Bentos we saw more excellent cotton in the third year of growth on "Taboleira " land measuring up to $45 \mathrm{~mm}$., and being very silky. The yield on this farm was $4801 \mathrm{~b}$. per acre lint and the ginning outturn $30 \cdot 8$ per cent.

For picking $1 \$ 500$ was paid. For ginning and baling $20 \$ 000$ to $23 \$ 000$ per 8 arrobas of 16 kilos lint. 
The present (July 1921) prices are:-

lst Class, $160 \$ 000$ lint per "carga " of 8 arrobas $=128$ kilos:

2nd , $80 \$ 000$ to $100 \$ 000$,

Expenses for eight arrobas lint :

$39 \$ 000$ for picking wages

$20 \$ 000$ for ginning and baling

$59 \$ 000$

The cotton is sold at present low prices at $160 \$ 000$, therefore $101 \$ 000$ remain to pay for labour, profit and interest.

There is further the seed equal to 18 arrobas which, at a very low price for cattle feeding, is worth $9 \$ 000$. Therefore a total gross. profit of $110 \$ 000$ per 128 kilos $=390$ reis per lb., from which must be deducted the slight amount of labour expended and interest on capital. This applies when the owner cultivates the land himself; when he has a tenant there remains 50 per cent. for the landlord clear. Planting takes place only every 10 or 15 years and weeding perhaps. once or twice a year.

The fencing of the property costs as much as the land. There are altogether three kinds of fences, viz. :

Present cost.

"Vara" (wattle fence) = $1 \$ 000$ for $2 \cdot 20$ metres

Stone with wattle on the top $=3 \$ 000$ for $2 \cdot 20$ metres

Stone alone $\quad=5 \$ 000$ for $2 \cdot 20$ metres

This terminates the tour through the Serido.

We now proceeded again by motor ears south of the Serido to Santa Luzia, which is situated in the State of Parahyba.

The principal interest in this town is the modern ginning factory of the "Sociedade Algodoeira do Nordeste Brazileiro," which has three large saw-gins of 50 blades, and at the time we visited three roller-gins of Platt Bros. \& Co., Ltd., Oldham, were being erected. These are the first roller-gins in the north-eastern part of Brazil.

The company has opened up schools at all their factories for the instruction in reading, writing and arithmetic, as well as agriculture, of their workpeople and their children.

We visited the Fazendas Fechado, Riacho da Varzea Alegre and Riacho dos Gatos. ("Riacho" means brook.)

In each of these places "Mocó" had a length of from $40 \mathrm{~mm}$. to $42 \mathrm{~mm}$., and the fields were well picked. There were decidedly more women workers in the fields here than in any part of Rio Grande do Norte. On the Fazenda Fechado efforts are being made to plant nothing but selected seed.

SÃo Mamede :

This is the next town we visited. It is situated on the river of the same name where the two affluents of the Riacho DA VArzea and Riacho dos Gatos meet. 
The cotton here was very good but we noticed some crossing between the "herbaceo" and "Mocó." The yield per acre was 482lb. To my mind this place is the limit where the Seridó-Mocó type of cotton grows, for at the next place-Riacho TATU-there was a distinct falling off in the cotton. It is noticeable that less care is taken in the cultivation, and again we got the mixture of "Maranhão," "Riqueza " and "Mocó."

We travelled by ears along the splendid main roads up to PomBAL, inspecting the cotton fields on the way.

At Patos, which is almost half way, we met again the President of the State of Parahyba-Dr. Solon DE LuCENA-who happened to be in this part of the country; he enquired as to our impressions.

At Pombal we were able to have a meeting with a large number of cotton cultivators, to whom we explained the necessity of pure seed and better methods of cultivation. 'This was very necessary as the cultivators had been told that they should alternate one row of "Mocó" with a row of annual cotton. The effect of such advice was clearly visible in the hybridisation that had taken place and, of course, the annual American type of cotton was mixed with Mocó in the ginning, causing the mixture of seeds and lint.

Unfortunately, we were not able to reach SouzA. This is a town which is likely to expand in the near future because several railway companies are building lines centreing on Souza, viz. :-

1. The Central Company do Rio Grande do Norte is being extended from Lages to Souza.

2. The railway from Mossonó is projected via S. SEBASTÃo, Carahubas to Souza.

3. The Great Western Branch from Campina Grande is to be extended to Souza.

4. The railway from LAvRAs in Ceará is to connect up with Souza.

5. The Central de Pernambuco Railway terminating at present at Barrão de Rio Branco is to be continued to Souza.

At Patos there was a very nice selected "Mocó" cotton; pretty strong, but the majority of fibres did not measure more than $32 \mathrm{~mm}$., though one boll measured $55 \mathrm{~mm}$. This was at the FAzENDA Queixado. The arroba here is 20 kilos.

We returned from Patos to Santa Luzia and proceeded via SoLEDADE to Campina Grande. Here the "Mocó" measured $32 \mathrm{~mm}$. only and was rather dark.

The chief interest at CAMPINA GRANDE is the very modern ginning factory of the "Companhia Parahybana de Prensagem E Beneficianento DE Algodão," in which the export firm of Messrs. Wharton, Pedroza \& Co., Natal, is largely interested. In this faetory there are three gins of 80 saw blades each with suction pipes and filler and a hydraulic press (Bridge, Castleton) turning out export bales. (See p. 170.)

Campina Grande is the great market for Parahyba and Pernambueo through which 200,000 bales, each of 64 kilos, pass annually. 


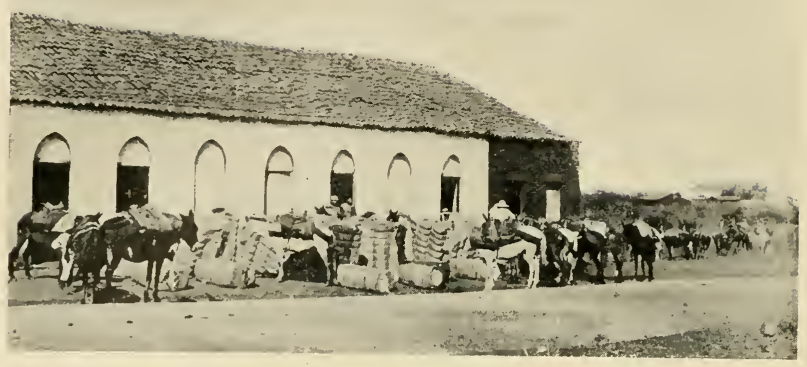

Loading the Pack Mules with Cotton Bales near Patos

Time did not permit me to visit the other cotton growing States of Brazil. These are :-

\section{MARANHÃO}

In this State cotton is the principal product and the Congress of the State seems to realise that the Government must take the necessary steps to improve and extend cotton growing. Various cotton experimental stations have been erected.

There are five distinct zones in the State, namely :

(1) Littoral, comprising the municipalities of Alcantara, Guimarães, Cururupú, Tury-assú, Santa Helena, Pinheiro and São. Vincente Ferrer.

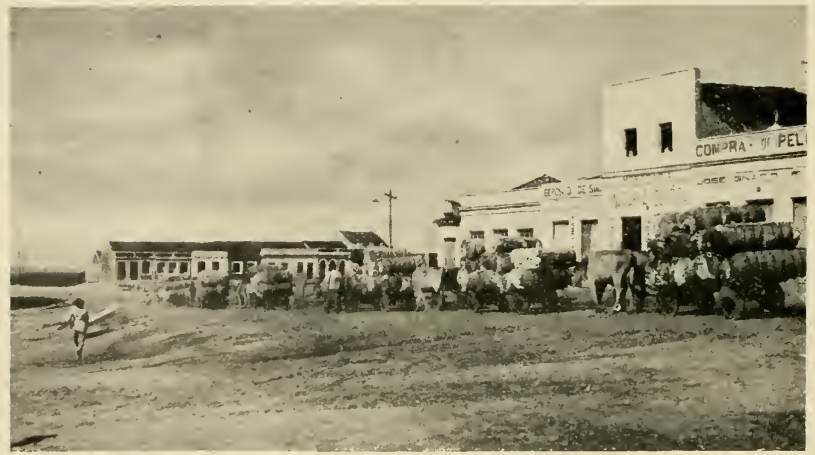

Cotton Haulage at Campina Grande, the great cotton Emporium of the North-East 
(2) Called "Pedreiras," comprising the municipalities of S. Luiz, Gonzaga, Pedreiras, Bacabal, Barra do Corda and Grajahú.

(3) Called "Itapecurú," comprising the municipalities of Itapecurú, Coroatá, Codó, Caxias and S. José dos Mattões.

(4) Called "Parnahyba," comprising Brejo, Burity, Curralinho, Santa Quiteria, Chapadinha and Vargem Grande.

(5) Called "The Sertão," comprising Picos, Mirador, Pastos Bons, Nova-York, Passagem Franca, São .João dos Patos and Barão do Grajahú.

\section{PIALHY}

The State of Piauhy possesses excellent conditions for the cultivation of cotton and there are evidently possibilities for the extension of the crop.

It seems that the central and southern zones are not yet opened up owing to lack of transport facilities and from reports received these promise to be splendid cotton growing districts.

Several Federal Government cotton experimental seed farms have been starterl in this State.

\section{CEARÁ}

This State grows quite a good quantity of cotton and evidently the Jaguaribe Valley, according to samples shown to me, can produce excellent qualities. (See Chapter xii.)

The largest cotton producing municipalities are :-

S. Francisco de Uruburetama, S. João de Itapipoca, União, Russos, Limoeiro, Ipú, I pueiras, Nova-Russos, Iguatú, S. Matheus, Pedra-Branca, Benjamin Constant, S. Pompeu and Morada-Nova.

The States of Goraz, PARÁ, and even the Territory of Acrè, are said to produce cotton.

Report by Dr. W. LAWRENCE BALLS, Chief of the Experimentat Departmont of the Fine Cotton Spinners' and Doublers'

Association Ltd., Bollington, near

Macclesfield on :

\section{“SOME PHYSICAL PROPERTIES OF THE SERIDÓ SAMPLES OF COTTON RECEIVED FROM MR. ARNO S. PEARSE."}

All the samples brought by Mr. Pearse from Brazil on the occasion of his visit there during 1921 were handed over to the Experimental Department of the Fine Cotton Spinners' and Doublers' Association for examination.

After discussion with Mr. Pearse, we arranged to examine in detail the two Ceará samples, the one sample of Verdão, the Sombrio and Espirito Santo samples of Mocó, and to take four more samples of Mocó at random to represent the remainder. 
Since the statistics thus obtained would be meaningless without some basis of comparison, we have put beside them similar figures taken from our records to show the kind of results given by good cottons from America and Egypt.

(1) The average of a dozen well-grown medium staple American Upland samples.

(2) A long staple but rather coarse Brown Egyptian of strain No. 77.

(3) A high grade extra Sakel cotton.

(4) Three other pure strains of Egyptian, No. 310 being a superSakel, while Nos. 95 and 111 more resemble Assili.

The statistical tests applied were as follows :-

\section{(A) HAIR BREAK}

These tests show the average results obtained by breaking 100 hairs at random, the length of each portion of hair tested being $1 \mathrm{~cm}$. taken in the middle of the hair. Results are expressed in grammes, and give some clue to the strength which may be expected in the yarn, provided that the yarns compared are all of equal regularity.

To effect this comparison for the same count, we have to take into consideration the hair break of equivalent weights of cotton. This has been indicated under the heading of " Relative Hair Break," which expresses the strength as shown by hairs of equal hair weight (D), i.e., equal fincness.

\section{(B) WALL THICKNESS}

The thickness of the cell wall of the hair is measured in 100 hairs indirectly by taking the difference between the total width of the hair at some one point of the width, and the width of the central canal, this difference being divided by two to give the thickness of the wall.

\section{(C) RIBBON WIDTH}

We use this term for what is commonly and inaccurately described as the diameter of the hair. It is determined at the same time as the measurements of wall thickness.

Cross Sectional Area. This can be calculated, if required, from the figures for wall thickness and Ribbon Width. It mainly follows the hair weight.

\section{(D) HAIR WEIGH'T}

A known length of hair is taken from the middle of each of a large numbers of hairs, and from the total weight of all these separate lengths we compute the average weight of a single centimetre of hair. Results are expressed in milligrammes per centimetre.

This test is one of the measurements of fineness, and from it can be calculated the number of hairs in cross section of any given kind of yarn. The lower the hair weight the more hairs there will be in 
cross section, and hence, other things being equal, the finer the count which can be spun without reducing the number of hairs in cross section too low.

\section{(E) SORTING}

All the samples were put through the Sledge Sorter, ${ }^{*}$ an illustration of which will be found in the advertisement pages of this volume, and the curves shown express the percentage distribution by weight for the various lengths of staple found in each sample. Duplicate tests were made on each sample, so that in this way some idca of the error of the test can be gathered.

It may be noted that the Ceará samples were difficult both to draft and sort owing to their extreme fineness.

It will be notieed that all the curves show an apparent tail of long hairs, but this-as explained in the handbook of the Sorter*-is fictitious: and to obtain a true idea of the composition of the samples, the rapidly falling front portion of the curve should be projected downwards to cut the base line.

\section{GENERAL COMMENTS ON OBSERVATIONS}

It will be seen that the Ceará samples (from the Jaguaribe valley) are extremely fine, whether judged by hair woight, or cven more so by ribbon width. Their hair break is, at first sight, rather low, but upon correcting for fincness, they are seen (in the "Relative Hair Break" column) to be greatly supcrior to the samples of Mocó and Verdão.

At the same time, this superiority is not abnormal. On comparing the Ceará with Sakel and No. 77 in this respect, they will be seen to be about equal thereto, whereas the Mocó and Verdão samples are not only inferior to Egyptian in this essential characteristic but also to the American. Although this fact appears unfavourable to the Mocó samples, it should be carefully observed that we are comparing country cotton from Brazil with crop cotton from experimental plots in America, and it is probable that better cultivation would lessen the difference.

This "Relative Hair Break" comparison is really the essential thing, and the other features of the tests are of comparatively minor interest; but it must be carefully observed that while "Relative Hair Break" shows the intrinsic strength of the yarn which the cotton may be expected to produce, it does not indicate whether the cotton will draft smoothly or not; and it is quite possible for a cotton which is intrinsically strong to behave so badly in drafting as to produce weak yarn. For this we have, as yet, no direct test, except the test of actual spinning $; \dagger$ and it should be noted that, as mentioned above, the Ceará samples were decidedly difficult to draft in preparation for sorting. In this respect, however, they merely resemble other very fine cottons.

* "A Method for Measuring the Length of Cotton Hairs" by W. Lawrence Balls (MacMillan \& Co., London, 1921).

$\dagger$ "A Handbook of Spinning Tests for Cotton Growers" by W. Lawrence Balls (MacMillan \& Co., London, 1920). 
The results of sorting the Ceará samples, especially Ceará 1, are, in consequence of this, not quite so sharp as we could wish them to be; but it is evident that in the latter we are dealing with a very long staple cotton, comparable to West Indian, but showing rather larger amounts of very short hairs than is perhaps usual, though by no means uncommon, with West Indian Sea Island. Ceará 2 is more like the high grade Sakel in respect of its length.

The Mocó samples show general similarity in respect of their length, and this is approximately the same as that of the average American sample.

The Verdão cotton is slightly shorter than the Mocó ones, the difference being barely ${ }_{8}^{1} \mathrm{in}$.

In conclusion, I am indebted to Miss E. Lanigan, in charge of our testing laboratory, and to her assistant, Miss Woodhall, for earrying out these tests and preparing the graphical illustrations thereof.

13th January, 1922 .

W. LAWRENCE BALLS.

TESTS MADE ON BRAZILIAN SAMPLES RECEIVED FROM Mr. ARNO S. PEARSE

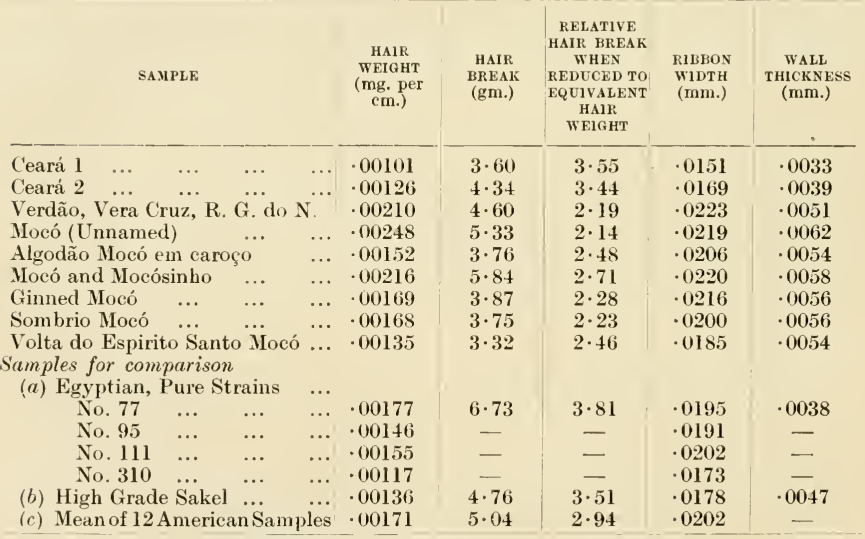

Note by Arno S. Pearse.-The two Ceara samples originate from the Jaguaribe Valley; the Sombrio Mocó and the Volta Espirito Santo Mocó samples were picked by me and probably represent cotton from the best farms visited by us. The other Mncó samples were given to me by the Official of the Agricultural Department at Caicó (Scridó). The Verdão sample is not a first-class one; this comes from Rio Grande do Norte, whilst better qualities of this kind of cotton are found in Alagôas, Sergipe, and Bahia.

The "Mocó" samples tested are those qualities which are used in Brazilian Mills for spinning up to 125's weft. If such counts can be predueed from Mocó by Brazilian labour in Brazilian mills, where fine spinning is only a recent innovation, it stands to reason that such cottons would spin higher counts in Lancashire and other countries. 
HAIR LENGTH TESTS MADE ON THE SLEDGE SORTER

CEARí 1

PERCEXTAEE WHILHT OF COTTON

LEXGTH

1ST TESTS 2ND TESTS MEAN

$\begin{array}{ll}\% & \% \\ 1 \cdot 7 & 2 \cdot 0 \\ 3 \cdot 0 & 2 \cdot 6 \\ 4 \cdot 2 & 3 \cdot 9 \\ 4 \cdot 8 & 5 \cdot 3 \\ 4 \cdot 6 & 5 \cdot 6 \\ 6 \cdot 0 & 5 \cdot 7 \\ 5 \cdot 1 & 5 \cdot 2 \\ 5 \cdot 3 & 6 \cdot 0 \\ 4 \cdot 7 & 4 \cdot 9 \\ 6 \cdot 9 & 6 \cdot 9 \\ 6 \cdot 6 & 5 \cdot 6 \\ 6 \cdot 4 & 5 \cdot 4 \\ 7 \cdot 6 & 6 \cdot 6 \\ 8 \cdot 3 & 6 \cdot 8 \\ 6 \cdot 3 & 6 \cdot 0 \\ 5 \cdot 4 & 5 \cdot 7 \\ 4 \cdot 5 & 4 \cdot 9 \\ 3 \cdot 5 & 3 \cdot 7 \\ 4 \cdot 9 & 6 \cdot 6\end{array}$

\section{VERDÃO}

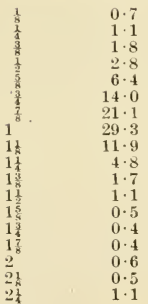

$0 \cdot 6$
$1 \cdot 0$
$1 \cdot 3$
$2 \cdot 0$
$4 \cdot 5$
$1 \cdot 2 \cdot 5$
$23 \cdot 2$
$20 \cdot 5$
$12 \cdot 0$
$8 \cdot 2$
$4 \cdot 9$
$2 \cdot 6$
$2 \cdot 2$
$1 \cdot 4$
$1 \cdot 2$
$0 \cdot 9$
$0 \cdot 9$
$0 \cdot 3$

$0 \cdot 6$
$1 \cdot 1$
$1 \cdot 6$
$2 \cdot 4$
$5 \cdot 4$
$13 \cdot 3$
$2 \cdot 2 \cdot 1$
$24 \cdot 9$
$12 \cdot 0$
$6 \cdot 5$
$3 \cdot 3$
$1 \cdot 8$
$1 \cdot 4$
$0 \cdot 9$
$0 \cdot 8$
$0 \cdot 8$
$0 \cdot 7$
$0 \cdot 7$

CEAR.i ?

PERCFNTAFF WFIGHT OF COTTON

LEXI:TH

1ST TESTS 2ND TESTS MEAN

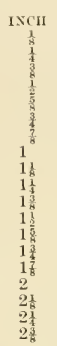

MOCÓ (UNNAMED)

\begin{tabular}{|c|c|c|c|}
\hline$\frac{1}{8}$ & $0 \cdot 5$ & 0.7 & $0 \cdot 6$ \\
\hline 1 & 0.4 & $0 \cdot 6$ & 0.5 \\
\hline$\frac{4}{3}$ & $0 \cdot 6$ & $1 \cdot 3$ & 0.9 \\
\hline & $1 \cdot 5$ & $1 \cdot 6$ & $1 \cdot 5$ \\
\hline$\frac{2}{3}$ & $3 \cdot 2$ & $3 \cdot 8$ & $3 \cdot 5$ \\
\hline 3 & $7 \cdot \overline{3}$ & $7 \cdot 9$ & $7 \cdot 6$ \\
\hline$\frac{4}{8}$ & $14 \cdot 4$ & $10 \cdot 3$ & $12 \cdot 3$ \\
\hline $1^{8}$ & $24 \cdot 7$ & $27 \cdot 5$ & $26 \cdot 1$ \\
\hline $1 \frac{1}{R}$ & $16 \cdot 8$ & $23 \cdot 9$ & $20 \cdot 3$ \\
\hline $1 \frac{1}{4}$ & $12 \cdot 8$ & $10 \cdot 7$ & $11 \cdot 7$ \\
\hline 13 & 8.4 & $4 \cdot 1$ & \\
\hline $1 \frac{1}{2}$ & $3 \cdot 2$ & 2.6 & \\
\hline $1 \frac{5}{N}$ & $1 \cdot 9$ & $\overline{1} \cdot 7$ & 1 \\
\hline 13 & $1 \cdot 4$ & 1.0 & \\
\hline 1 & $1 \cdot 1$ & 0.9 & $1 \cdot 0$ \\
\hline & 0.7 & 0.6 & 0.6 \\
\hline & 0.6 & 0.4 & 0. \\
\hline & 0.4 & 0.4 & 0. \\
\hline
\end{tabular}

MOCÓ FRON VOLTA DO ESPIRITO SANTO

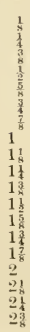

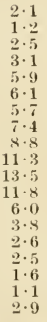

$\begin{array}{r}1 \cdot 7 \\ 1 \cdot 3 \\ 2 \cdot 6 \\ 3 \cdot 5 \\ 5 \cdot 6 \cdot \\ 6 \cdot 4 \\ 6 \cdot 7 \\ 8 \cdot 3 \\ 9 \cdot 8 \\ 11 \cdot 4 \\ 12 \cdot 0 \\ 9 \cdot 8 \\ 6 \cdot 0 \\ 4 \cdot 1 \\ 2 \cdot 9 \\ 2 \cdot 4 \\ 1 \cdot 6 \\ 1 \cdot 4 \\ 2 \cdot 4 \\ \hline\end{array}$
HIGH GRADE SAKEL

\begin{tabular}{|c|c|c|c|}
\hline$\frac{1}{8}$ & - & - & - \\
\hline$\frac{1}{1}$ & - & 0.8 & 0.4 \\
\hline$\frac{4}{3}$ & - & $1 \cdot 0$ & 0.5 \\
\hline$\frac{1}{1}$ & $1 \cdot 2$ & $1 \cdot 6$ & $1 \cdot 4$ \\
\hline$\frac{2}{5}$ & $3 \cdot \overline{0}$ & $3 \cdot 6$ & 3 . \\
\hline 3 & $4 \cdot 4$ & $6 \cdot 7$ & 5. \\
\hline$\frac{4}{6}$ & $7 \cdot 1$ & $7 \cdot 9$ & $7 \cdot 5$ \\
\hline $1^{\circ}$ & $8 \cdot 9$ & () 6 & $9 \cdot 2$ \\
\hline $1 \frac{1}{\mu}$ & $10 \cdot 5$ & $11 \cdot 2$ & $10 \cdot \overline{8}$ \\
\hline 13 & $13 \cdot 7$ & $14 \cdot 9$ & $14 \cdot 3$ \\
\hline $1 \frac{3}{6}$ & $15 \cdot 4$ & $13 \cdot 3$ & $14 \cdot 3$ \\
\hline $1 \frac{1}{2}$ & $14 \cdot 2$ & $11 \cdot 7$ & $12 \cdot 9$ \\
\hline 15 & $8 \cdot 6$ & $7 \cdot 2$ & $7 \cdot 9$ \\
\hline $1 \frac{3}{4}$ & $5 \cdot 6$ & $4 \cdot 2$ & $4 \cdot 9$ \\
\hline $1 \frac{2}{2}$ & $3 \cdot 0$ & $2 \cdot \overline{5}$ & $2 \cdot 7$ \\
\hline $3^{\circ}$ & $2 \cdot 1$ & $1 \cdot 6$ & $1 \cdot 8$ \\
\hline 21 & $1 \cdot 6$ & $1 \cdot 2$ & $1 \cdot 4$ \\
\hline $2 i$ & 0.9 & $1 \cdot 1$ & $1 \cdot 0$ \\
\hline
\end{tabular}


164

BRAZILIAN COTTON

HAIR LENGTH TESTS MADE ON THE SLEDGE SORTER-(continued)

ALGOD̃̃O MOCÓ EM CAROCOO

PERCENTAGE WEIGHT OF COTTON

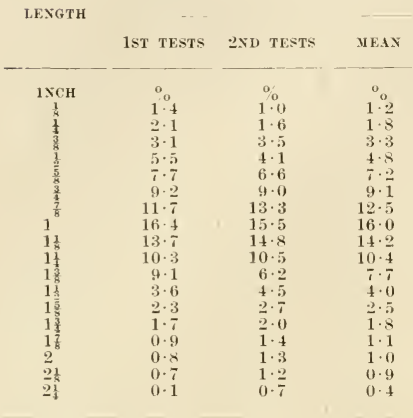

MOCó AND MOCOSINHO

PERCENTAGE WEIGHT OF COTTON

LENGTH

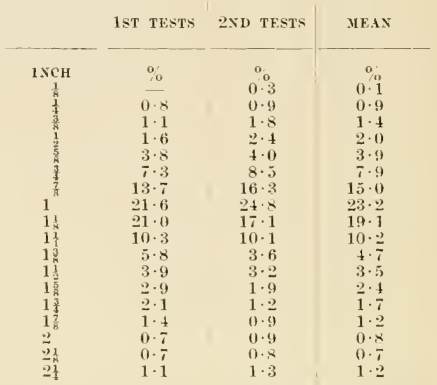

GINNED MOCó

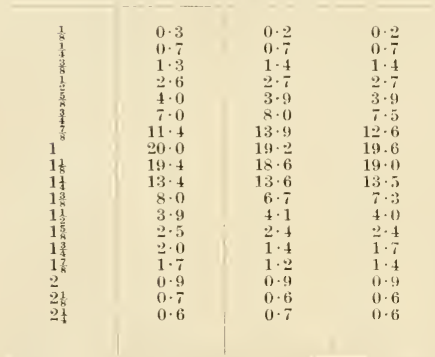

MOCÓ FROM SOMBRIO

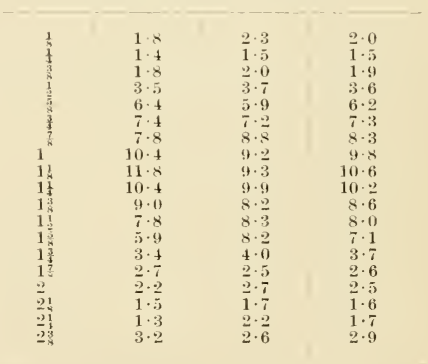

EGYPTIAN, PURE STRAINS

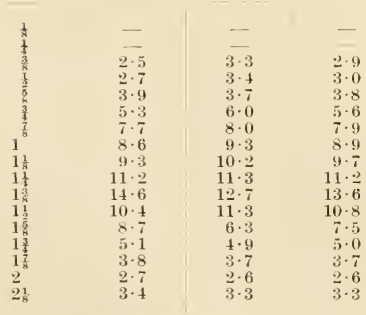

MEAN OF 12 AMERICAN SAMPLES

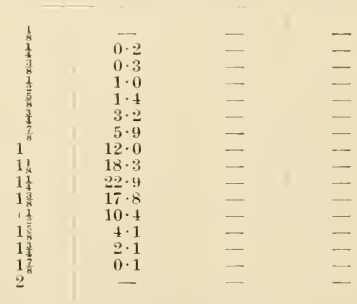


DR. W. LAWRENCE BALLS' SLEDGE SORTER TESTS ON MR. PEARSE'S BRAZILIAN SAMPLES

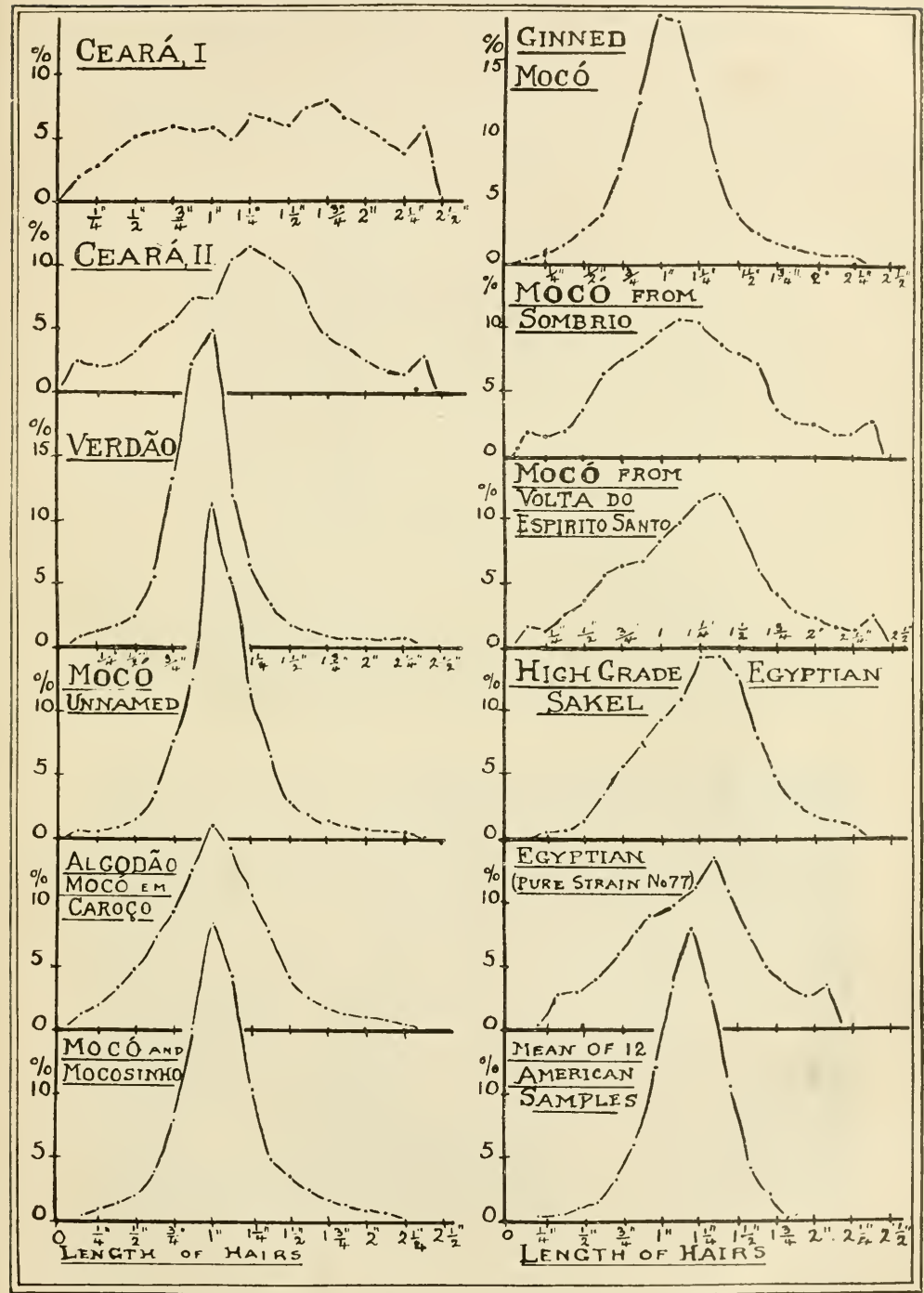

Note BY Arvo S. Pearse-The Mocó Cottons from the farms "Sombrio" and "Volta do Espirito Santo" show remarkable equality in the above charts with the High Grade Egyptian Sakellarides f'otton. 


\section{Chapter XI}

\section{THE COTTON EXPORT HOUSES OF PERNAMBUCO, PARAHYBA AND RIO GRANDE DO NORTE.}

The following is an alphabetical list of exporters of cotton who have hydraulic or other high density bale presses :-

Boris Frères \& Co., Natal, Rio Grande do Norte;

Boxwell \& Co., Recife, Pernambuco ;

Kroencke \& Co., Parahyba;

Mendes. Lima \& Co., Pernambuco

Pinto Alves \& Co., Pernambuco ;

Julius von Söhsten \& Co., Parahyba, etc. ;

José de Vasconcelles \& Co., Recife, Pernambuco;

Wharton Pedroza \& Co., Natal, Rio Grande do Norte.

These firms have their selling agents in Liverpool and further on in this chapter will be found their names together with the description of the shipping marks of the cottons they sell.

The bale press to which so far general preference is given in the north-eastern part of Brazil is one made by Fawcett, Preston \& Co., Ltd., Liverpool, turning out a bale of $48 \mathrm{in}$. by $17 \mathrm{in}$. by 2 lins., weighing $400 \mathrm{lb}$.; the tare is $10 \mathrm{lb}$. During the war, owing to the difficulty of prompt delivery, two horizontal bale presses of Bridge, Castleton, near Rochdale, have been sent out ; these are able to press up to a density of $60 \mathrm{lb}$; one of these bales of $400 \mathrm{lb}$. measures $19 \frac{1}{2} \mathrm{in}$. by $20 \mathrm{in}$. by $35 \mathrm{in}$.

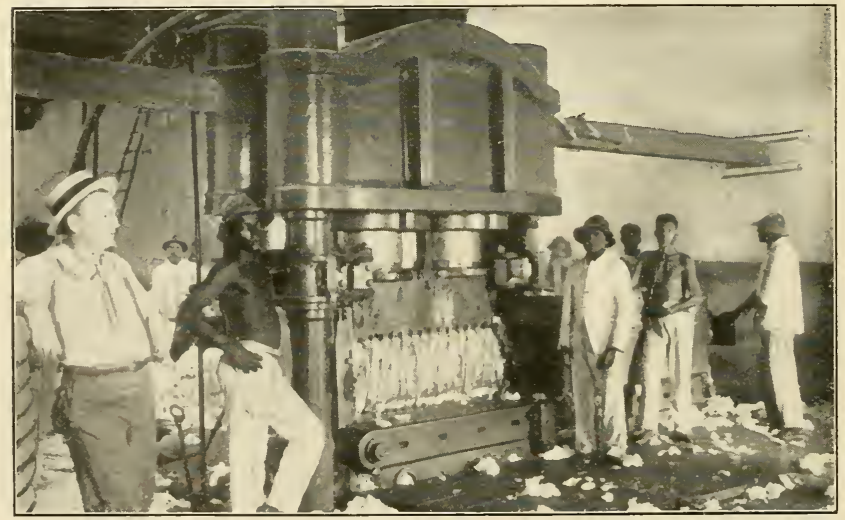

Fawcett, Preston \& Co.'s hydraulic Bale Press at Messrs. Kröncke \& Co., Parahyba

This kind of press is used by most of the Cotton Exporters of North Brazil 


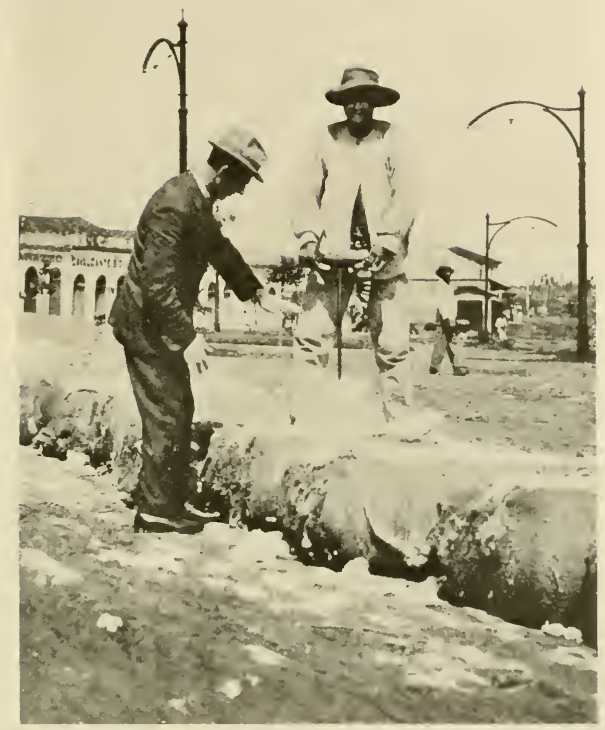

Cotton Sampling in the Streets of Parahyba

The makers of the Fawcett* presses claim to be able to turn ont up to 40 bales an hour, whilst the information given me by one of the owners of the other press was that the maximum outturn was 25 bales per hour. I pointed out to the two firms possessing the horizontal press that short staple cotton like that of India, where Bridge's press is well introduced, can stand a pressure of $561 \mathrm{~b}$. per cubic foot, but that I thought long staple Brazilian cotton might possibly suffer from such a pressure. The pressure in these horizontal presses can be regulated and there is no need to use such a high density. The Egyptian bale has a cubic density up to 3.1 b. per cubic foot, and the Cotton Control Board at Manchester-whose dictum may be considered as absolutely authoritative-decided that American bales must on no account be pressed to a higher density than $36 \mathrm{lb}$. : this was in reply to the American compresses which during the war, owing to shortage of freight, intended to make bales of $42 \mathrm{lb}$. instead of $281 \mathrm{~b}$. to the cubic foot. Trial shipments of bales of varying density from these horizontal presses are now on the way to Lancashire for expert opinion.

The following is more or less the system of handling the cotton adopted by all the above firms :-

\footnotetext{
* Perhaps the latest machines have a greater output.
} 
The cotton is bought at the office of the exporter from brokers and small up-country merchants on a secure contract; loosely packed small bales, generally 64 kilos each, ${ }^{*}$ some slightly heavier, are delivered in the warehouses in the towns of exporter (at port); each bale is sampled in the presence of the seller and classified there and then as either first, second or "refugo" (throw-outs). Only the price of the first grade is fixed in the contract at the time of purchase, the deduction for seconds is agreed to at the time of sampling: when we were in these parts it was almost 50 per cent. less than first. "Refugos" could not be sold at any price to exporters.

The lots are, of course, kept separate in the stores and, according to the requirements and established mixings of each firm, they are taken to the press room. Here the process of separating long and short fibre really begins and the dirty cotton and clean cottons are

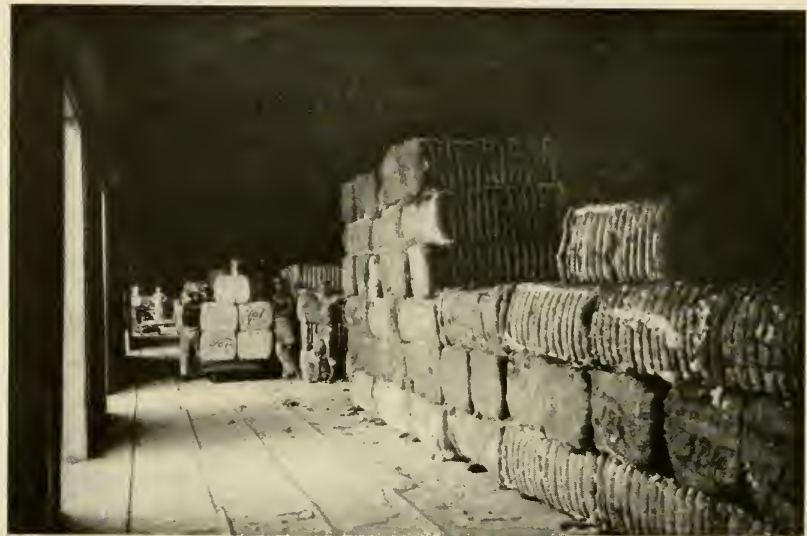

Part of Cotton Warehouse of Kroencke \& Co., Parahyba, showing Export Bales

further separated. Layers of the opened bale are placed on a slanting table whose surface consists of small wooden rollers, allowing dirt and dust to fall through, on each side of this table stand four men taking out dirty and dead cotton, and as they perform this work they pass the good cotton on to the next man who again casts his eyes over it, picking out undesmable stuff and loosening the cotton at the same time, and so on, each man pushing the cotton to his neighbour. A foreman checks the length of the cotton in each bale as it is opened and generally supervises the work on the table. The unsuitable cotton is thrown behind the men in a pile and only the selected cotton passes along the slanting table, at the end of which it reaches a simple contrivance for

* As these bales have to travel long distances on mules, the weight is limited to 64 kilos each, one being placed on either side of the mule. 
further opening and mixing, consisting of a slowly rotating wooden beater, having six arms each $1 \frac{1}{2}$ in. wide; this tosses the cotton up, riddles it further and throws it on an open platform where a number of men, by means of wooden forks further loosen and mix the cotton, pushing it gradually into one of the weighing boxes that are on either side of this platform. A bell indieates when $400 \mathrm{lb}$. of cotton are in the box: it is then deposited in the box of the press with which the weighing box is in close contact. Meanwhile the other weighing box is filled. There are two boxes (in the old presses three) in each Fawcett press, as the bale is pressed twice. The number of bales which can be sorted and pressed in a given time depends on the state of the cotton delivered. All the export firms have this or a similar method of mixing and pressing; it depends, of course, a good deal on the punctilious manner in which this work is performed; the process itself is no secret.

Two of the firms had part of the cotton passing through a Creighton Opener before sending it on to the slanting table, but I pointed out that this machine often robs the cotton of the bloom as it is frequently run too fast.* Another firm had in place of the roller table an endless trellis table mechanically rotating; a third firm was doing without the table and spread the cotton out on the floor, as is done in Alexandria. This latter process cannot get rid of the dirt as well as the slanting table does. At one place we were told that the Creighton opener enabled the firm to improve seconds and even "refugo" to first-class cotton, taking out as much as 15 per cent. dirt.

The shipping marks, the names of the European firms, etc., as far as I eould ascertain, are as follows :-

Boris, Frères \& C'ie, Natal, Ceari and Paris.- The Natal house is undergoing at present some changes; during the last two years little cotton has been shipped from there. The shipping marks are known as BF Seridó, BF Sertão and BF Matta, generally sent to Liverpooi.

The principal house is at Ceará, where a very large quantity of cotton is handled for shipment to Liverpool, Havre, and all the Continental markets. The best known mark from the Ceará house is $\mathrm{BF} / \mathrm{G}$, classed as fully fair to good fair, average length of fibre $29 / 32 \mathrm{~mm}$., used largely for mixing with Egyptian eotton.

Boris Frères \& Cie are established at 65 , rue de la Victoire, Paris; in Liverpool they sell through Messrs. W. R. Roberts \& Co., 4, Irwell Chambers, Fazakerley Street, and in Havre through M. Ernest Moch, 146, Bd. de Strassbourg.

Boxwell \& Co., Pernambuco.

$\begin{array}{ccccc}\text { J.H.B. } & \ldots & 40 / 45 \mathrm{~mm} . & \ldots & \text { Only up to } 1,000 \text { bales in a year. } \\ \text { K. } & \ldots & 38 / 40 \mathrm{~mm} . & & \\ \text { B.X.L. } & \ldots & 35 / 37 \mathrm{~mm} . & \ldots & \text { Special first Sertão. } \\ \text { Amor } & \ldots & 30 / 34 \mathrm{~mm} . & \ldots & \end{array}$

* Brooks \& Doxey (1920) Ltd., Manchester, are making the "Youlten Cotton Opener," a machine which opens the cotton on a new principle; it is claimed for this machine that it takes out more dirt than any other Opener and that the "bloom "is not damaged, but increased. 
They have a few other marks, which they sell mostly to the Brazilian mills, but we often saw "Amor" in our inspection of mills.

Boxwell \& Co. sell only through Messrs. William Tanner Boxwell, Son \& Co., C13, Exchange Building, Liverpool.

Kroencke \& Co., Parahyba.

\begin{tabular}{|c|c|c|c|c|c|}
\hline Name. & & Description. & & Lel & igth not under \\
\hline Eagle & $\ldots$ & Special Sericló, crea & $\mathrm{m}$ & . & $36 \mathrm{~mm}$ \\
\hline $\mathrm{MC}$ & . & Seridó, cream & . & . & $35 \mathrm{~mm}$. \\
\hline Star & . & ,, medium, as & MC, but leafy & $\mathrm{y} \cdot$ & $35 \mathrm{~mm}$. \\
\hline Sol & . & Sertão, white & . $\quad \ldots$ & abont & $32 \mathrm{~mm}$ \\
\hline Sky & . & Mata $1 . \quad \ldots$ & $\ldots \quad \ldots$ & $\ldots$ & $28 / 30 \mathrm{~mm}$ \\
\hline Luna & . & ," II. not as clea & an as Sky & . & r \\
\hline Mars & . & ,, III, medium & . $\quad \ldots$ & . & , \\
\hline S.B. & . & Refugo ～. & . & . & 'ickings \\
\hline
\end{tabular}

Kroencke \& Co. sell only through Messrs. F. Albrecht \& Co., 3 , St. Paul's Square, Liverpool.

Pinto Alves \& Co., Pernambuco.

This firm ships all the cotton ginned by tbe "Sociedade Algodeira Nordeste Brazileiro": it sells through Messrs. F. Albrecht \& Co., Liverpool, Strauss \& Co., Liverpool, and others.

LEX . . lst Seridó $1 \frac{7}{16}$ in. classed last year in New York as "strictly midlling."

About 2,600,000lib. from the PAX .. Sertão $1 \frac{1}{1} \mathrm{in}$. 1921 crop were sold to the U.S.A. and half was classed APOLLO .. , $\quad 1_{16}^{3}$ in. as "middling" and half as "strictly low middling."

Julies von Soehsten \& Co., Parahyba, etc.

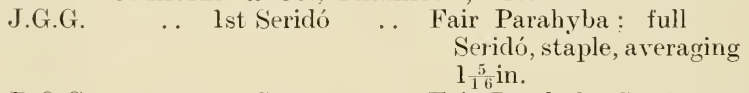

D.O.G. . lst Sertão .. Fair Parahyba Sertão staple, average length $1 \frac{3}{16}$ to $1 \frac{1}{4} \mathrm{in}$.

IXI

Fair Parahyba, Matta staple, $1 \frac{1}{8}$ in.

Emma _. . . . . . Nedium fair Parahyba, Seridó staple, average lengtlı $13 \mathrm{in}$.

This firm sells only through Messrs. Williams, Palmer \& Co., 4/10, Knowsley Building, Tithebarn Street, Liverpool.

José, de Tasconcellos \& Co., Pernambuco.*

W.P. \& Co. . . 1st Seridó . Extra quality, full Serido, Primus .. staple $1 \frac{3}{8}$ in.

IV.P. \& Co. . . lst Sertão . Fair Pernambuco Sertão, Primor .. staple $1 \frac{3}{16}$ to $\mathrm{I} \frac{1}{4} \mathrm{in}$.

W.P. \& Co. . . lst Matta . Fair Pernambuco Matta, Primata staple averaging $1 \frac{1}{8} \mathrm{in}$.

This firm sells only through Messrs. Williams, Palmer \& Co., Liverpool.

* A new Fawcett Press is being erected by them. 
Wharton Pedroza \& Co., Natal.

$\begin{array}{llcll}\text { Ozone } & \ldots & \text { Seridó } & \ldots & \text { Up to } 1 \frac{1}{2} \mathrm{in} . \\ \text { Alpha } & \ldots & , . & \ldots & 1 \frac{1}{4} \text { to } 1 \frac{3}{16} \mathrm{in} . \\ \text { Beta } & \ldots & , & \ldots & 1 \frac{1}{4} \mathrm{in} .\end{array}$

Gamma, first medium Seridó

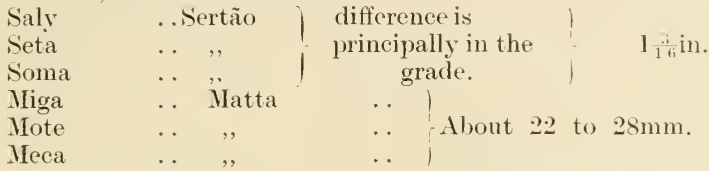

This firm sells through Messrs. Alexander von Glehn \& Co., Liverpool.

The very important firm of Mendes. Lima \& Co., Pernambuco, has recently acquired a second-hand Fawcett Press and intends to export cotton. Their qualities have not yet been established.

I mention these particulars because I feel sure that Brazilian cottons are not sufficiently known by spinners and no doubt many of them wonld like to make a trial, especially this season, owing to the great shortage of staple cotton from America, which has suffered so severely from the boll-weevil. There is a great difference in prices between Brazilian and other staple cottons, Brazilian being much lower. The reason for this difference is accounted for by the slight variation of Brazilian cotton from bale to bale, but if the spinner buys from a reliable firm and samples each bale, a work which should not take long, he will find that he gets well compensated for the extra trouble. As the boll-weevil has now entered North America's long staple district spinners will have to realise that for years to come the supply from these parts must be short.

Entil now the Brazilian exporters bought their cottons in the offices at the port, but recently two firms, Messrs. Pinto Alves \& Co. and Wharton Pedroza \& Co. have interested themselves financially in ginning factories in the interior of Parahyba and Pernambuco.

One export firm made as much as 2,000 contos advances on the crop before it was picked, according to information given me in their office.

The construction of the excellent high roads, both in Parahyba and Rio Grande do Norte (also part in Pernambuco), make it possible for these exporters to enter the interior. Hardly any of the exporters had been in the interior prior to our visit, and when the President of the State of Parahyba gave them the opportunity of joining us they gladly availed themselves of it. It is only in the last year or two that the construction of these fine motor roads has been undertaken; in many places the very massive bridges are not vet finished, but the roads are open for traffic in the dry season; where the bridges have not been finished temporary roads are constructed through the low-lying parts. The surface of these roads is excellent. the cars can travel at a good speed and it is to be hoped that funds will always he available to keep them in good repair. The net of such roads is already very extensive as can be seen from the following table of roads upon 
some of which the "Sociedade Algodoeira" has even established a cheap service of motor omnibuses :-

Campina to Soledade, $60 \mathrm{~km}$.

Soledade to Joazeiro, $26 \mathrm{~km}$.

Joazeiro to Santa Luzia, $54 \mathrm{~km}$.

Santa Luzia to Patos, $48 \mathrm{~km}$.

Patos to Pombal, $80 \mathrm{~km}$.

Parelhas to Santa Luzia, 44km.

Jardim do Seridó to Acary, $26 \mathrm{~km}$.

Jardim do Seridó to Parelhas, $20 \mathrm{~km}$.

Caicó to Acary, $45 \mathrm{~km}$.

Acary to Corraes Novos, $30 \mathrm{~km}$.

Curraes Novos to Natal, 160km.

Jardim do Seridó to Campinas, $184 \mathrm{~km}$.

A road has been started from Lages via Assú to Mossoró.

In Pernambuco there is a good motor road from Barrão do Rio Branco to Alagôa do Baixo, Alagôa do Monteiro; part of this road is being constructed by the "Sociedade Algodeira" for account of the Government. In a few years this net of roadways will cover the whole of the north. Motor lorries carry now from the ports heary goods used in the construction of the bridges, etc., and were it not that petrol is so expensive, owing to Brazil's low rate of exchange, the cotton bales would be sent by motor lorries to the termini of the railways. Considering that alcohol is being manufactured from sugar in large quantities in Pernambuco, Alagôas and Sergipe, the time will not be far distant when this powerful fuel will be used in these parts as a substitute for petrol in the driving of motor vehicles. Recent development in Europe has proved that with little alteration of the engine alcoliol can be used to advantage.

All these places in the heart of the fine cotton growing zones have suddenly been brought into rapid contact with the outside world. where formerly days and days of fatiguing mule travel were necessary. In short, the roads are revolutionising social and commercial life and some few firms have recognised this by establishing themselves in the interior. The effect of this move will be far reaching. The ginning factories being established on the basis of special Government concessions must deliver for planting purposes pure seed without charge to all the planters in the district. We can therefore hope that the owners of these ginning factories will realise that by distributing pure seed of one variety only, they will be placed in a position to sell in the coming years uniform cotton. To my mind, the mistake made is that all these modern factories are worked by saw gins. whilst in this entire part nothing but roller-gins should be used. The Brazilian as a rule is very keen on making money and employing it in the extension of his business, but in the establishment of his saw-ginning factories, he has been short-sighted, too eager to turn out quantity and not paying sufficient regard to quality. One requires on an average three and a half roller-gins to do the work of one 50 blade saw-gin, but the value of the fibre ginned by the rollers much more than compensates for the smaller out-turn. Even if the rollergin saves only $2 \mathrm{~mm}$. in the length of the fibre, it would pay to employ them, but the difference in length realised is much greater. (See p. (j0.) 
The great interior cotton market in the north is "CAMPINA GraxdE" ; some $\mathbf{2 0 0 , 0 0 0}$ bags of 64 kilos pass annually through here, where they are put on rail for Pernambuco or Parahyba. The principal cotton merchants of this place, who are more doing the work of the American cotton factor, are :

Demosthenes Barboza \& Co. ;

José Ignacio Monteiro \& Co.;

Virgilio Maracajá ;

Leitão \& Co. ;

José de Britto.

These firms must often make advances to the small cultivator, buving cotton " $\mathrm{em}$ folha" (in the leaf), as it is called. i.e., before it is harvested. When an exporter gets an order he generally makes his contract with one of these factors, they collect the cotton required, but they often have to buy in anticipation. These men do not examine the cotton, they merely buy according to locality and are satisfied if a bale has the traces of having passed through a certain press. Thus in order to hoodwink these factors cotton grown outside the Serido is sent there solely for pressing with the intent of selling it as legitimate Seridi, and the fraud is found out only when the bale is opened in the warehouse of the exporter. The cotton factors do not know the qualities of cotton, but they are clever and keen merchants.

Undoubtedly the establishment of ginneries and presses by exportors in the interior will do away to some small extent with the cotton factor; he will be required merely there where a cultivator is forced to sell in the "leaf " before picking, as I do not think many exporters will be found to undertake this kind of business. It is not so much the elimination of the "factor" which will be accomplished. but the distribution of pure seed by intelligent firms who recognise that their own welfare, that of the cultivator and of the State depends on the judicious distribution of the seed. The whole of the inhabitants of the up-country places coming now through the construction of motor roads into eloser contact with more educated people, are bouncl to profit in civilisation and they will recognise as they are undoubtedly beginning to do, that in these north-eastern States exist great natural possibilities for the extension and improvement of cotton, if they apply themselves to a few elementary reforms.

Strange to say, none of the modern ginning factories are in the "Seridó"; the place " par excellence" for growing real long staple cotton. There is undoubtedly an opportunity of development in this direction in this district.

Recognising that through the establishment of roller-gins in the very heart of the country the supply of cotton from there would improve not only in quality but also in quantity, I have tried to influence the exporters to undertake the execution of a scheme of erecting a chain of roller-ginneries and the ideal plan would be if this could be done in co-operation by the exporter, importers and spinners. No party would need to contribute large funds, all would benefit by such an undertaking. The cotton would certainly improve and the ginning factories would be a lucrative investment, as the States of Rio Grande do Norte and Parahyba would make such concessions as 
to guarantee almost a safe return on the capital employed. The firms established as exporters have the staff to look after the factories.

$$
\text { ** * }
$$

In the previous chapters mention has frequently been made of the various establishments of the "CoMpanHIA INDESTRIAL DE Alcoda e Oleos," whose head offices are at Rio de Janeiro. Rue São José, 76 ; Mr. Trajaxo S. V. Meneipos is the president. For easier reference I append herewith a summary of the concerns of this Company and of the "Sociedade Nordeste Brasileiro."

I regret that all these gimning factories comprise solely saw gins and not one roller gin. These factories are the practical outcome of a Cotton Congress held in Rio de Janeiro in 1916. Besides granting concessions in the form of reduced export taxes the Government has even made loans to this Company.

The following is a description of the concerns of this Company :

Garanhuns Gin Plant (State of Pernambuco).-Is located on the south line of the Great Western of Brazil Railway, Ltd., distant 270 kilometres from Recife. This plant has four gins of 60 saws each. with cleaning feeder, condenser, double box hydraulic press, provided with steam packer or tramper. Bales obtained at this press have an average weight of 180 kilos, measuring $1 \cdot 2 \cdot 2$ by 0.61 by $0.58 \mathrm{~m}$. The capacity of these four gins is 30,000 kilos of seed cotton in 10 hours' work. A 70 h.p. boiler and engine are used at the power house of this plant. In a separate room operates a cotton cleaner and the cotton cleaned there is re-pressed at the gin press. The belt distribut or of cotton over the gins and the brushes are substituted on this plant by the air blast system, i.e., two fans do the work of the belt and brushes acting on the saws. Beside the gin building, two large rooms have been built for storing the seed cotton and a third room for the bales. All the buildings are of brick and covered with tiles. A branch of the Great Western Railway runs along the platforms of these storerooms and this is a great advantage for handling the cotton in and out. The cotton seed is removed to a modern seed-house fully equipped with conveyors, elevators, etc., for handling the seed in, distributing, cooling and carrving to the oil mill. This plant has been in operation since 1919 .

Opposite to the gin plant there is an oil mill for crushing the seed obtained from the gins and bought in the neighbourhood. This oil mill has a capacity of 20 tons of seed in 12 hours' work. The machines are of the very late models manufactured in the United States. The power house is equipped with a 150 h.p. boiler (type Babcock \& Willcox) and a Corliss engine. This mill is working now.

São Caétano Gin Plant.-Is located at 160 kilometres from Recife, on the central line of the Great Western Railway. With regard to buildings, machinery, power house, handling facilitics. etc.. this plant is absolutely identical to Garanhuns gin plant. The oil mill. however, has the capacity of 5 tons of seed a day. The gin plant has been in operation since 1918 .

Limoeiro Gis Plant.- Is located in the village of Limciro do Norte station of the Great Western Railway, 83 kilometres from 
Recife. This plant has four gins of 70 saws each. The system of gins, condenser, press, etc., is the same as on the two plants above. The capacity is 35,000 kilos of seed cotton a day. An antomatic engine and a tubular boiler of $100 \mathrm{~h} . \mathrm{p}$. have heen installed at this plant, making a better power house. The seed obtained at this place is consumed at Recife. This plant started ginning in 1920 .

Sapé Gix Plant (State of Parahyba do Norte.-Is located at the village of Sapé, 46 kilometres from Parahyba (town). This plant is irlentical to Limøeiro gin plant and the oil mill next to it is in every item equal to the oil mill at Garanhuns. This gin plant has been in operation since 1920 and the oil mill has just started.

Patos Gin Plant--A gin plant and an oil mill of the same type and size of the installations of Sapé will be erected at Patos. Part of the machines are already bought.

Souza Gin Plant.-A gin plant and oil mill identical to the sapé gin and oil mill will be installed at Souza. The machinery for these two plants is near to Souza and the buildings are going on.

Nova Cruz Gin Plant (Rlo Grande do Norte). - Is located at 140 kilometres from Natal, to which town it is connected by the Great Western Ralway. This plant is of same capacity of São Caetano and Garanhuns. No oil mill will be installed at Nova Cruz, and the seed obtained there will be shipped to Sapé in Parahyba. This plant is nearly finished.

Iguatú Gin Plant (State of Ceará.-This plant is located on the Estrada de Ferro de Baturité (railway), 413 kilometres from Fortaleza. The capacity of this gin plant and oil mill is the same as Sapé and Souza installations. Both gin plant and oil mill are in operation.

Sobral Gin Plant.-Is of the same size and type of Iguatú, Souza and Sapé. This gin plant is located in the north of the state of Ceará, on the Sobral Railway, 1.5 kilometres from the port of Camocim. The building; are finished but the machinery not erected yet.

Oil Mill at Pernambuco.-The largest oil mill of the company is located at Recife (Pernambuco). This plant is connected to every railway line in the States of Alagôas, Pernambuco, Parahyba and Rio Grande do Norte and by water and rails to Pernambuco docks. The seed house has a eapacity of 5,000 tons of seed and is equipped with up-to-date machinery. 'The oil mill capacity is 40 tons of seed in 12 hours run.

At the same place the company installed a large plant for refining 30 tons a day of cotton seed oil received from the several oil mills, and make compound lard, winter oil and soap, for home consumption and export. The departments for refining oil (summer oil) and making of soap are working already.

The company has already in Pernambueo 14 railway freight cars and four oil tank cars for the transport of cotton, cotton seed and oil from the gin plants and oil mills up country.

The "Sociedade Algodoeira do Nordeste Brazileiro." a limited company registered as Cavalcanti \& Co., with a capital of 
$1,000,000 \$ 000$, head offices at Recife, Pernambuco, 234, Apollo ( $2^{\circ}$ andar), P.O.B. 187, has established similar modern ginning factories as the preceding firm.

Its establishments are situated at Timbaúba, Rio Branco and Limoeira in the State of Pernambuco, and at Santa Luzia in the State of Parahyba. The Company has further obtained concessions for the establishment of similar factories at Pieuhy, Pombal and São João de Cariry in the State of Parahyba, and at Alagôa do Monteiro and Alagôa do Baixo in the State of Pernambuco.

All these concessions stipulate that in eonnection with a ginning factory, an experimental cotton plantation must be worked and that good seed has to be delivered free to all the growers of the district who apply for it.

The State, in consideration of these undertakings, grant considerable concessions in the rate of export tax, local taxation, and allows machinery to be imported free of charge.

This company is closely connected with the cotton merchanting firm of Pinto, Alves \& Co., Pernambuco. Besides attending to the ginning, the firm has established a separate road construeting department, which undertakes this kind of work on behalf of the Government, receiving a fixed percentage on all outlays. The technical manager, Engro. J. F. Brandro Cavalcanti, is one of the most hard-working men I had the pleasure of meeting in Brazil, and he knows the country thoroughly, having been one of the first advocates of the construction of motor roads throughout the Northeastern part of Brazil. I am indebted to him for a good deal of information.

Quite an extensive omnibus service is run by this company and excellent schools have been established in connection with the manysided undertakings of the firm.

There is a third firm which owns a very modern ginning factory, viz., "The Companhia Parahy bana de Prensagem e Benefrciamento DE ALGODÃo" at Campina Grande. The cotton export firm of Wharton, Pedroza \& Co., is largely interested in this concern.

Though Compina Grande is not in the heart of the cotton growing district, it is a large cotton emporium where a considerable portion of the Serido cotton is sold and put on the railways.

There is little difference between the new ginning faetories just described, except that in the Campina establishment there is a highpower bale press of Messrs. David Bridge \& Co., Ltd., of Castleton, Lancashire, turning out bales of a density of from 50 to $60 \mathrm{lbs}$. per cubic foot, whilst the other two companies do not possess high density bale presses.

The "Companhia Industrial de Algodão e Oleos" does not buy cotton, but merely gins "on commission": it buys cotton seed. The other two concerns buy the seed cotton. 


\section{Chapter XII.}

\section{BRAZIL'S CHIEF EXPORT COMMODITIES.}

The subsequent list shows the statistics of Brazil's ten chief com. modities of export.

Cotton has been dealt with in the preceding chapters and a short resumé on Coffee has been given at the end of the chapter dealing with São Paulo, as it is pre-eminently a Paulista crop.

The following notes on the remaining commodities are worthy of the attention of the student of Brazil's possibilities. It must be borne in mind that many of these products are used as rotating crops with cotton and therefore it does not seem out of place to mention these particulars in a report dealing principally with cotton.

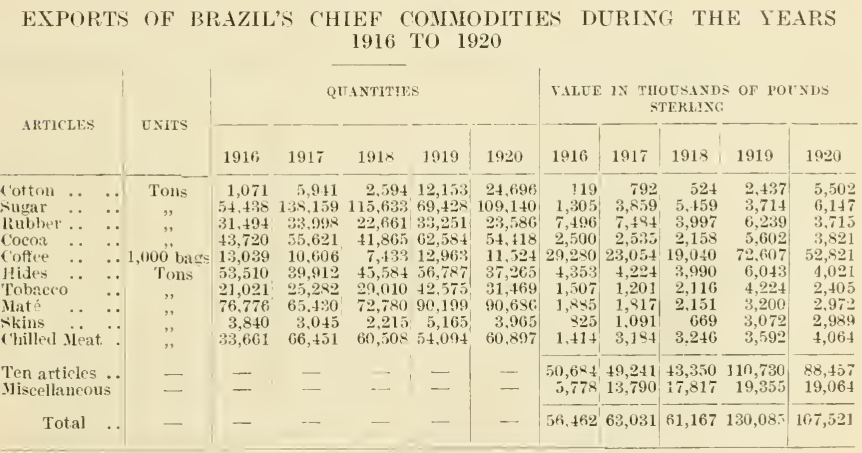

(OUNTRIES OF DESTINATION

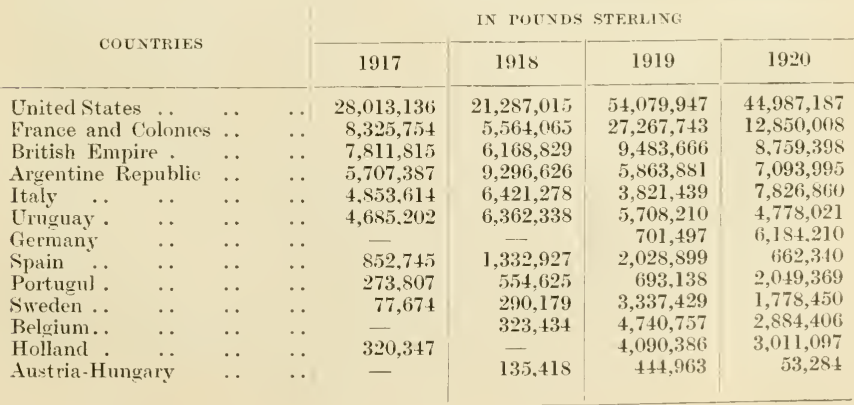


EXPORTS OF ALL KINDS OF PRODUCTS, BY STATES

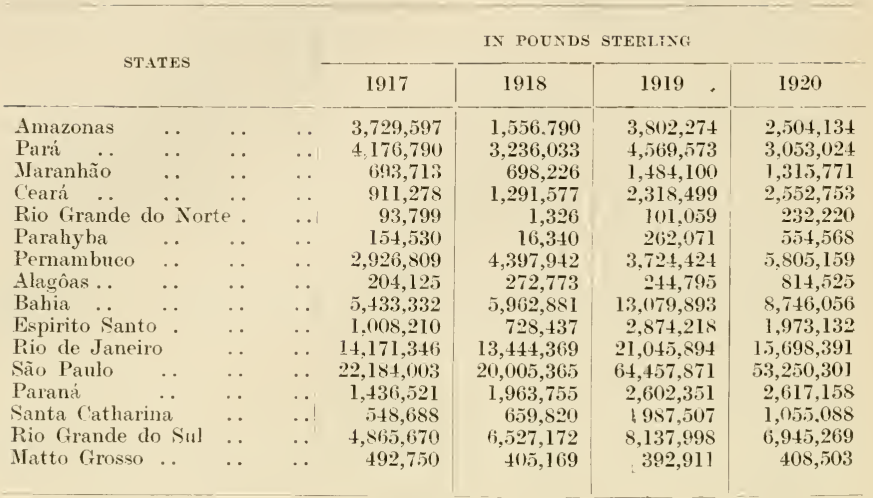

Of the ten chief products mentioned in the first table coffee occupies easily the first place, sugar the second ylace and cotton came third in 1920. The U.S.A. are by far the best customer of Brazil, the major quantity of imports being coffee. France occupies now the second place and Great Britain the third. The State of São Paulo leads, of course, as regards exports, due chiefly to the coffee exports; the same applies to the second, Rio de Janeiro. Bahia comes third in consequence of cocoa exports, hides, etc. Pernambuco, from which State most of the cotton is exported was only fourth in importance during 1920. The falling off in rubher exports is clearly risible from the first table and from the third.

Sugar is the second produce of importance as an export commodity. At one time Brazil was a great sugar-cane country, but the yields per acre cannot compete with Java, the Sandwich Islands, etc., as will be seen from the following particulars:-

Tons of cane per hectare.. Per cent. of sugrar ... ..

'Tons of cane per hectare.. Per cent. of sigar ... ..

Tons of eane per hectare.. Per cent. of sugar ... ..

\begin{tabular}{|c|c|c|c|}
\hline \multicolumn{4}{|l|}{ SAXDWICII } \\
\hline ISLAXDS & JAVA & DEMERARA & C'CBA \\
\hline 82 & 80 & 62 & 50 \\
\hline 15 to $15 \cdot 5$ & 14 to $15 \cdot 5$ & ? & 13 to 15 \\
\hline S. PaUlo & CAMPOS & Pernaybeco & PARAHYBA \\
\hline 50 & 50 & 50 & 40 \\
\hline 13 to $1+5$ & $14 \cdot 5$ to $15 \cdot 5$ & 11 to $12 \cdot 1$ & 11 to $12 \cdot 1$ \\
\hline SERGIPE & ALAGôAS & ВАнІА & \\
\hline $\begin{array}{c}54 \\
11 \text { to } 12-5\end{array}$ & $\begin{array}{c}55 \\
12 \text { to } 15\end{array}$ & $\begin{array}{l}45 \\
1] \text { to } 12\end{array}$ & \\
\hline
\end{tabular}

The expansion of the beet sugar industry and the carelessness on the part of the Brazilian cultivators are the main causes why Brazil receded from the position of the first and most important world supplier of sugar to the sixth place. The beet sugar industry supplies to-day $6 \frac{1}{2}$ million tons more sugar than the cane industry, whose total world's production is calculated at $5_{\frac{1}{2}}^{1}$ millions. 
Sugar in Brazil is principally planted along the coast, this part having the necessary humid-hot elimate, except in Sito Paulo, which has sufficient water up-country. The States in which sugar cultivation is most advanced are shown in the table at the end of these notes on sugar, but it is grown in every State wherever there is a supply of water. Seed selection is not practiced and generally haphazard cultivation is resorted to. The planting is done by making a small hole with the hoe into the soil in this is embedderl a piece of cane with a few sections (eyes), generally taken from the top portion of the cane. The holes are one meter apart, eareful weeding is a great advantage, but few are the plantations where the necessary three clearings are given. Within fourteen months from planting the cane is ripe, up to twelve canes grow from one hole and the sugar field presents by that time a real tropieal aspect, a rlense mass of canes with fresh green leaves. The canes are then chopped off, cleaned of leaves and taken to the crushing mill. The following illustration shows one of the many "engenhos" or small primitive sngar mills which we inspected in the course of our journeying.

In these small "engenhos" the squeezing rollers are turned by a mule, on the system of the Persian wheel; the juice which flows from the rollers is ealled "calfla de camna" and this is boiled over open fires. Through fermentation and distillation of the syrup, carried out in an old-fashioned plant, alcohol is obtained and "eachaça," the Brazilian whisky, is prepared. The "calda de canna." is a very wholesome drink, non-intoxicating, whilst the "cachaca " is a strong alcoholic liquor. used for making rum. In the neighbourhood of large refineries the smell of "cachaca" is very strong and contaminates

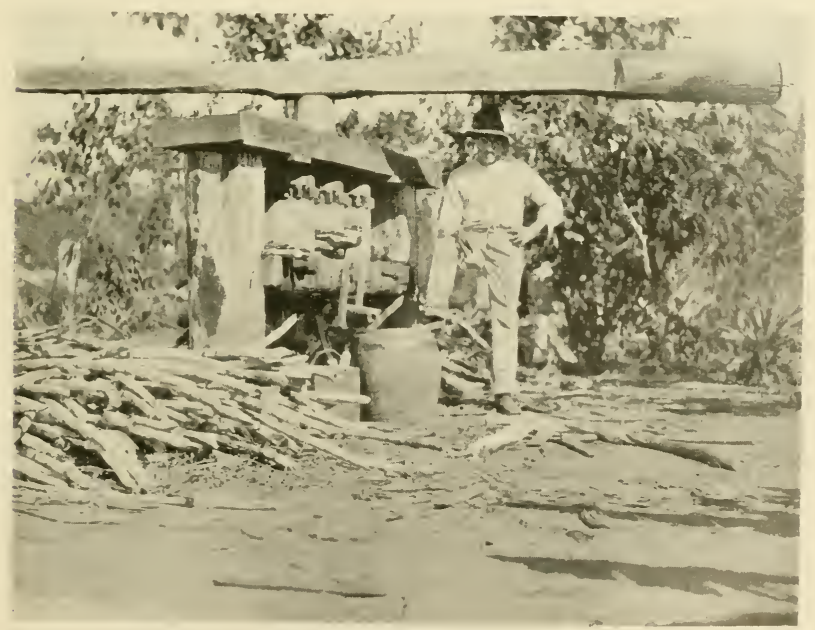

A primitive Sugar-cane Mill 


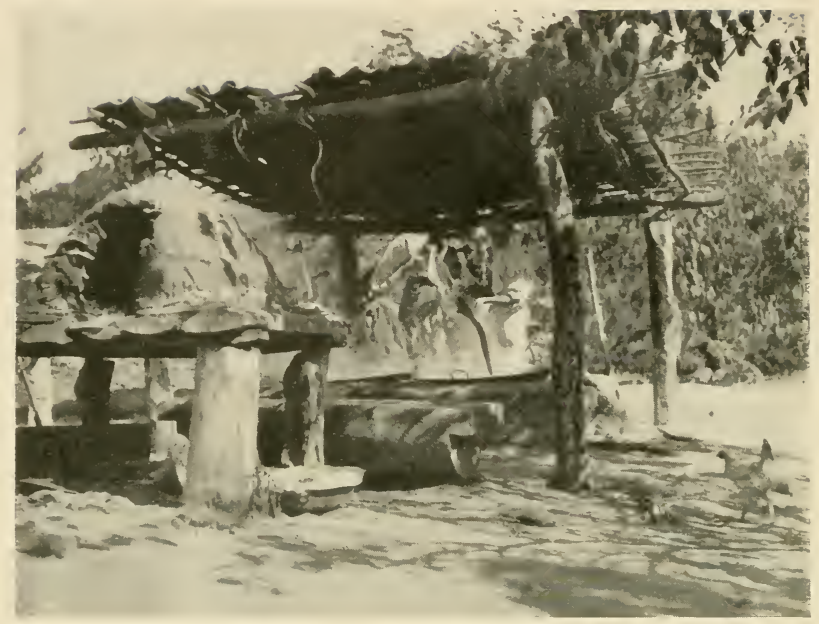

The Boiling of Sugar at Biriguy (São Paulo)

On the left-hand side is one of the customary baking ovens

the air. As in view of the high price of petrol motor-driving is becoming almost prohibitive, it would appear that the use of sugar alcohol might present an excellent substitute for petrol, and I would arlvise interested parties to get into touch with the Professor of Chemistry at the ILanchester University, where considerable research work in this direction was earried out during the war. Brazil's low rate of exchange and the consequent high price of petrol is at present stopping the transportation by automobiles, whilst excellent high roads in the northern States are not lacking; it is just there where sugar growing is most developed. The State of Pernambuco has most of the modern sugar mills, but they are met with in lesser numbers in any of the exporting States. We visited one belonging to the "Siociété Sucrerie Brésilienne," at Piracicaba, capable of crushing 60 tons of cane in 24 hours. The erushing mills were made by the Cie de Fives, Lille, and the rats by Brissonneau Fils \& Cie, Nantes. The company has considerable areas of land where sugar is grown. The soil stands 15 years continuous sugar eultivation; by that time the yields become small and rather than manure or rotate with other crops, a new "roça," is made, i.e., stretches of forest are burnt off, cleared and cultivated. Such a system of impoverishing the soil is almost criminal. The wholesale burning of forest is tending to change the climate and is, of course, wasting the resources of the nation. In a recent Brazilian Government publication it is stated: "The growing of sugar cane in Brazil, with rare exception, is carried on by antiquated and anti-economical methods. We have not yet any industrial establishments possessing the requisite elements for the 
extraction from the cane of a pereentage of sugar equal to that obtained in Hawai, Cuba, Java, ete." To me it seemed that there is plenty of scope for the work of many botanists. Contrary to what I saw in India sugar eanes are allowed to flower in Brazil.

There have been a great many violent fluctuations in the export of sugar from Brazil, the last impetus to the trade was given during the War. At the beginning of the twentieth century the exports mored between 300,000 and 350,000 tons, then they fell off to 200,000 , and since then were as follows:

\begin{tabular}{|c|c|c|c|c|c|c|c|c|}
\hline \multicolumn{9}{|c|}{ SUGAR EXPORTS } \\
\hline Tons & $\ldots$ & $\ldots$ & .. & $\begin{array}{c}1906 \\
84,948\end{array}$ & $\begin{array}{c}1907 \\
12,858\end{array}$ & $\begin{array}{c}1908 \\
31,577\end{array}$ & $\begin{array}{c}1909 \\
68,485\end{array}$ & $\begin{array}{c}1910 \\
58,824\end{array}$ \\
\hline Tons & $\ldots$ & . & . & $\begin{array}{l}1911 \\
36,208\end{array}$ & $\begin{array}{c}1912 \\
4,772\end{array}$ & $\begin{array}{l}1913 \\
5,367\end{array}$ & $\begin{array}{l}1914 \\
31,860\end{array}$ & $\begin{array}{c}1915 \\
59,074\end{array}$ \\
\hline Tons & . & . & . & $\begin{array}{c}1916 \\
53,074\end{array}$ & $\begin{array}{c}1917 \\
138,159\end{array}$ & $\begin{array}{c}1918 \\
115,633\end{array}$ & $\begin{array}{c}1919 \\
69,429\end{array}$ & $\begin{array}{c}1920 \\
109,142\end{array}$ \\
\hline
\end{tabular}

\begin{tabular}{|c|c|c|c|c|c|c|c|c|c|}
\hline \multirow{2}{*}{ STATES } & \multirow{2}{*}{ Pol:Ts } & \multicolumn{4}{|c|}{ KILOS } & \multicolumn{4}{|c|}{ POUXDA STERING } \\
\hline & & 1917 & 1918 & 1919 & 1920 & 1917 & 1918 & 1919 & $192 n$ \\
\hline Amazonas .. & M:unãos & 580 & $3, \pm 66$ & 4,050 & 11,680 & 31 & 171 & 308 & 795 \\
\hline Pará $\quad \ldots \quad \ldots$ & Belém .. . . & 8,951 & 47,492 & $\begin{array}{r}7,000 \\
19,933\end{array}$ & 24,625 & 462 & 2,837 & $1,6: 20$ & 2,039 \\
\hline Maranhão & S. Luiz $\cdots$ & 5,220 & 5,370 & 92,582 & 1,852 & 207 & $\begin{array}{r}-, 005 \\
275\end{array}$ & 6,280 & 156 \\
\hline C'earál & Fortaleza ... & 130 & 128 & $\longrightarrow$ & $\begin{array}{r}1,000 \\
60\end{array}$ & -20 & 11 & - & 5 \\
\hline Rio G. lo Sorte & Natal .. & 379,968 & -12 & 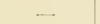 & 200,040 & 4,620 & -11 & - & 7,780 \\
\hline Parahyba & Cabedello & 424,945 & - & 106,075 & - & 5,780 & - & 3,805 & $1-$ \\
\hline Pernambuco ... & Recife & $82,836,949$ & $75,931.028$ & $37,835,358$ & $71,816,247$ & $1,882,550$ & $3,377,740$ & $1,860,465$ & $3,932,720$ \\
\hline Alagóas... .. & llaceió ... . & $5,695,+13$ & $6,061,816$ & $\begin{array}{r}4,233,475 \\
\end{array}$ & $9,9+8,942$ & 101,441 & 225,743 & 172,005 & 485,776 \\
\hline liatha $\quad \ldots \quad \ldots$ & s. Salvador .. & $9,599,580$ & $12,532,820$ & $6,369,160$ & $4,487,430$ & 323,840 & 605,078 & 361,098 & 312,802 \\
\hline Finl. District & Rio de Janciro & $30,013,374$ & $19,647,848$ & $20,676,666$ & $20,779,949$ & $1,303,912$ & $1,151,9$ S0 & $1,302,097$ & $1,253,0: 38$ \\
\hline S. Paulo . . & Santos ... .. & $2,034,429$ & 625,330 & 19,157 & $1,228,377$ & 73,897 & 37,535 & 1,183 & 99,528 \\
\hline S. Cathariua . & Florianopolis. & 324,000 & 36,000 & - & 567,180 & 8,454 & 1,250 & - & 39,200 \\
\hline $\begin{array}{l}\text { Rio Grande do } \\
\text { Sul } \ldots\end{array}$ & Various Ports & 820,111 & $6 \pm 6,263$ & $72,12: 3$ & 86,165 & 31,672 & 33,821 & 5.199 & 5,797 \\
\hline Mlatto Grosso . & Corumbá $\quad$. & $\underline{2}, 790$ & $\longrightarrow$ & - & 7.650 & 145 & - & - & 534 \\
\hline- & Other Ports.. & 12,180 & 96,000 & - & 80,717 & $24^{2}$ & 4,020 & - & $i, 050$ \\
\hline & & $138,1,59,020$ & $115,633,561$ & $69,423,879$ & $109,141,914$ & & & & \\
\hline
\end{tabular}

The Government has recently erected experimental stations and in 1905 the industrials combined and decided, with a view to keeping up the sugar prices in Brazil, to "dump" the surplus to England. of which advantage this country availed itself to a considerable extent. Whilst in the period from 1901 to 1905 England took only $16 \cdot 7$ per cent. and the U.S.A. $8 \cdot 2 \cdot 7$ per cent. Englanrl's share rose to $57 \cdot 2$ per eent. in 1906, whilst the U.S.A. covered their requirements more and more in Cuba, reducing their imports from Brazil to $35 \cdot 8$ per cent. of the total sugar exports.

The total production of sugar in Brazil is about 540,000 tons, which shows that large quantities are consumed in the rountry, which is accounted for by the frequenu partaking of coffee, for in each cup the Brazilian puts from 3 to 6 spoonfuls of sugar. A good deal of sugar is used in the fruit preserving industry, which has a great future; the jellies and marmalades, amongst which the "goiabada de Pesqueira" enjoys the highest reputation in Brazil, are likely to become of world repute. 
Cattle.-The rearing of cattle and pigs is undertaken at every cotton plantation; it is the staple industry of Rio Grande do Sul. Goyaz, Minas Geraes, but it also flourishes in São Paulo, Matto Grosso, Parahyba, Rio Grande do Norte, in fact in every State cattle are heing raised.

During the last decale it is being realised by the Agricultural Department and by the individual farmers that the native stock requires improvement by introducing selecterl foreign breeds, for which purpose the Indian Zebu bulls seem specially liked, as they withstand more readily the hot climate. Farmers are proud of their Zebu and Herefordshire bulls, and a veterinary Govermment service is actively engaged in preventing the diseases to which foreign cattle are prone. Only the thoronghbreds and milch cows are fed, all other cattle have to find their own food on the pasture lands. On our journeys in the interior we frequently met huge herds of cattle which had travelled in charge of a few "vaqueiros" or cow herds hundreds of miles. On these journeys the cattle becomes of course thin and every now and then a halt of considerable duration has to be made.

Each farm has a "corral," an enclosure of fences, made of tree branches, where early in the morning milking takes place. The Brazilian cow refuses to give milk unless its calf is close to her; the calf is tied on the front leg, whilst the cow is milked. Thus the farmer cheats his cow into the belief that the calf is getting the milk.

The latest Goverrment cattle statistics show what an important industry the rearing of cattle has become.

CATTLE-STATISTICS

NEMBER OF HFAT

\begin{tabular}{|c|c|c|c|c|c|c|c|c|}
\hline \multirow{2}{*}{\multicolumn{2}{|c|}{ STATES }} & \multirow{2}{*}{ ISOYIXES } & \multirow{2}{*}{ HORSES } & \multirow[b]{2}{*}{$\begin{array}{l}\text { MULES AND } \\
\text { DONKFYS }\end{array}$} & \multirow{2}{*}{ GOATS } & \multirow{2}{*}{ SHEEP } & \multirow{2}{*}{ HoGs } & \multirow{2}{*}{ TOTAls } \\
\hline & & & & & & & & \\
\hline Jistricto Federal & $\ldots$ & 16,000 & 10,000 & 13,000 & 5,000 &,+ 000 & 16,000 & 61,000 \\
\hline Alagôas $\quad \ldots$ & .. & 260,000 & 82,000 & 21.000 & 819,000 & 207,000 & 93,000 & 982,000 \\
\hline Amazona - & .. & 212,000 & 11,000 & 6.000 & 6,000 & 10,000 & 40,000 & 315,000 \\
\hline Bahia & . & $2,683,000$ & 825,000 & 572,000 & $3,005,000$ & $2.22+.000$ & $2,410,000$ & $11.719,000$ \\
\hline Cearit. & . & $1.162,000$ & 421,000 & 281,000 & $1,495,000$ & $1,304,000$ & $2 \times 6,000$ & $5,149,000$ \\
\hline Esperito Santo & . & 161,000 & 62,000 & 94,000 & 87,000 & 22,000 & 503,000 & 879,000 \\
\hline Goyaz. . & .. & $1,873,000$ & 316,000 & 84.000 & 90,000 & 95,000 & 710,000 & $3,168,000$ \\
\hline Marauhāo .. & .. & 610,000 & 132,000 & 34,000 & 190,000 & 92,000 & 245,000 & $1,323,000$ \\
\hline Matto Grosso. & .. & $2,050,000$ & 270.000 & 12,000 & 17,000 & 26,000 & 175,000 & $3,050,000$ \\
\hline Mina (icrass. & .. & $6,5 \in 1,000$ & $1,744,000$ & 779.000 & 517.000 & 447,000 & $6 ., 16,000$ & $17,064,000$ \\
\hline Pará $\ldots \quad \ldots$ & . & 541,000 & 34,000 & 7,000 & 13,000 & 27,000 & 104,000 & 726,000 \\
\hline Paralis ba & . & $¥ 18,000$ & 172,000 & 50,000 & 818,000 & 486,000 & 168,000 & $2.483,000$ \\
\hline Parani . & . & 540,000 & 230,000 & 101.000 & 35,000 & 70,000 & $69 ?, 000$ & $1,675,000$ \\
\hline Pernambuco. & . & 871.000 & 274,000 & 106,000 & $1.692,000$ & 464.000 & 222,000 & $3,700,000$ \\
\hline Piaulyy $\quad \ldots$ & . & $1,16:, 000$ & 266,000 & 96,000 & 638,000 & 516,000 & 325,000 & $3,004,000$ \\
\hline Rio d. Janciro & $\cdots$ & 519.000 & 156.000 & 101,000 & 124,000 & 85,000 & 738,000 & $1,726,000$ \\
\hline Rio Frande to Nort & & 573,000 & 139.000 & 105.000 & 418,000 & 357.000 & 99.000 & $1,655,000$ \\
\hline Rio (irande do S-1l & . & $7.249,000$ & $1,422,090$ & 201,000 & 87,000 & $3.7+5,000$ & $2,204,000$ & $14,908,000$ \\
\hline Santa Catharina & . & 521,000 & 129,000 & $+6,000$ & 13,000 & 35,000 & 360,000 & $1.104,000$ \\
\hline Săo Panlo .. & .. & $1.322,000$ & 509,000 & $41 \bar{T}, 000$ & 297,000 & 282,000 & $1,934,000$ & $4.761,000$ \\
\hline Sergipe $\quad \because$ & . & 269,000 & 83,000 & 8,000 & 202,000 & 149,000 & 76,000 & 814,000 \\
\hline Territorio do Acre & .. & 7,0110 & 1,000 & 7,000 & 1,000 & 3,000 & 5,000 & 24.000 \\
\hline Totals .. & .. & $30,705,000$ & $7,289,000$ & $3,208,000$ & $10,049,000$ & $10,633,000$ & $18,399,000$ & $80,503,000$ \\
\hline
\end{tabular}

The frozen and chilled meat industry is a new enterprise created by the requirements of the War, the first consignment was shipped to Europe in 1914. Four packing houses have been established.

The first packing company was established at Osasco, State of São Paulo, and is capable of realing daily with 1,000 heads of cattle, 


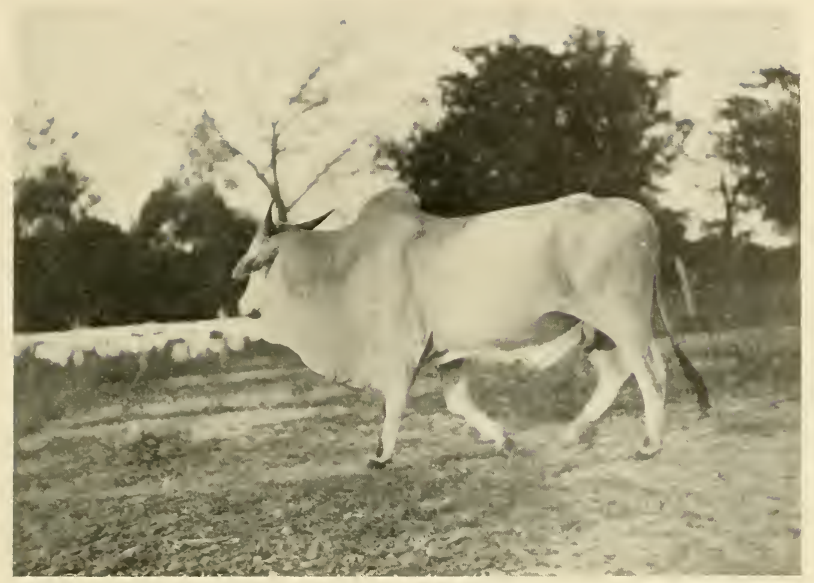

Introduction of Zebu cattle from Irıdia is much favoured.

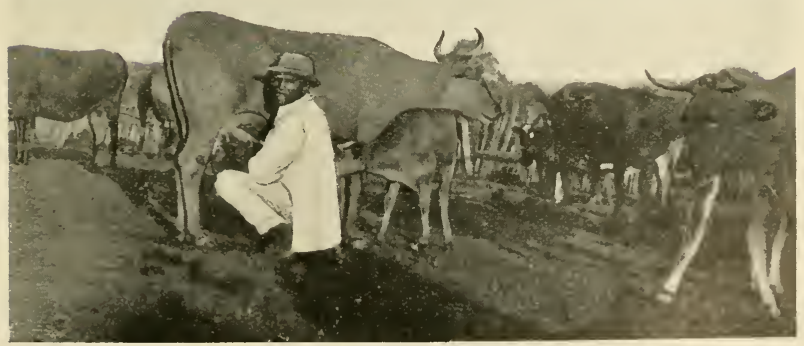

During milking the Calf is tied to the front Legs of the Cow, otherwise the Cow refuses to give milk 
2,000 sheep and 4,000 hogs. The style of the firm is the "Continental Products Co." The second is also in São Paulo at Barretos, near Santos, it is called the "Companhia Frigorifica e Pastoril" and is entirely a Brazilian company. Vestley Bros. of London and Chicago have established a plant at Mendes in the State of Rio de Janeiro. At Rio de Janeiro are the "Armazens Frigorifieos dos Cáes rlo Porto" ; no killing is done at the latter place, but the freezing and chilling processes are carried on. This firm gets the eattle killed at the slaughter-house of Rio de Janeiro.

At Rio Grande do Sul there are three packing houses and an extension is contemplated.

The development of this new industry is shown by the following figures of exports of frozen and ehilled micat :--

\begin{tabular}{|c|c|c|c|c|c|}
\hline & & $191+$ & 1915 & 1916 & 1917 \\
\hline Kilos ... ... & . & 1,500 & $8,513,970$ & $33,660,936$ & $66,451,967$ \\
\hline Value $£$ sterling & . & 63 & 309,706 & 1.414 .460 & $3,184,461$ \\
\hline $\begin{array}{l}\text { Kilos . . . } \\
\text { Value } £ \text { sterling }\end{array}$ & $\begin{array}{l}\ldots \\
\ldots\end{array}$ & $\begin{array}{c}1918 \\
60,508 \\
3,246,395\end{array}$ & $\begin{array}{c}1919 \\
51,633,556 \\
3,381,486\end{array}$ & $\begin{array}{c}1920 \\
60,897, \tilde{5} 46 \\
4,064,358\end{array}$ & \\
\hline
\end{tabular}

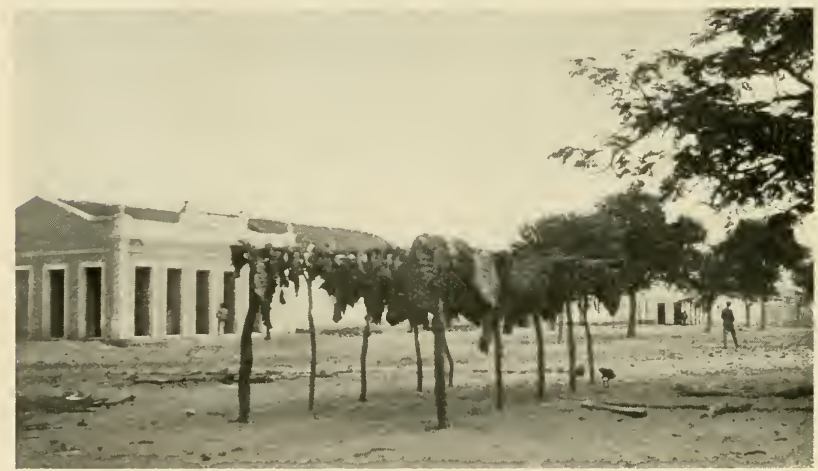

Preparation of Sun-dried Meat

Such stands are seen in every village along the São Francisco River

Jerked beef ("xarque"), i.e., sun-drier beef is largely consumed in Brazil. Here is a photograph showing how it is prepared; this meat tastes exceedingly good, though is somewhat hard.

Hides of oxen, sheep and goats constitute an important source of income owing to the existence of a number of shoe and boot factories in the country which turn out an excellent article, well able to withstand foreign competition. There is a large export trade done in hides, principally to the U.S.A., particulars of which are given on next page :- 
EXPORT OF HIDES

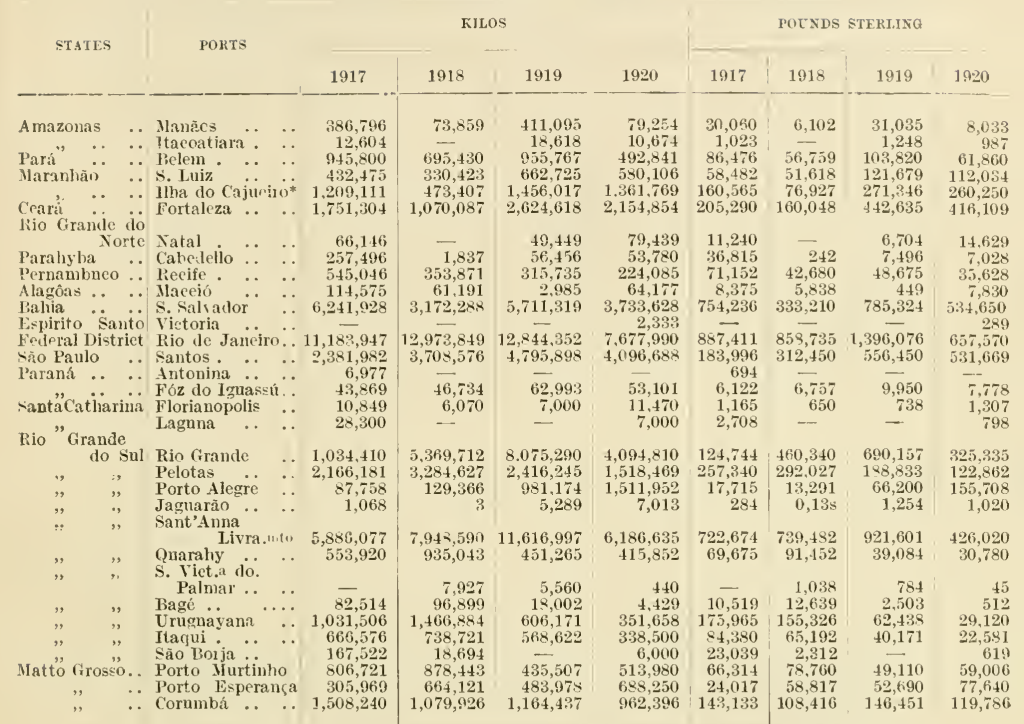

*Exports from the State of Pianhy are made by the port of Ilha do Cajueiro.

The skins of wild animals are generally spoilt, because they are mostly killed by shot guns, still Ceará exported one million worth in 1920. There is a great choice of wild animals, such as "onças" (leopards), "lontras," wild hoars, deer and inonkeys.

Cocoa is the principal crop of Bahia, the exports from this State being :-

\begin{tabular}{|c|c|c|c|c|c|c|}
\hline & & & 1917 & 1918 & 1919 & 1920 \\
\hline & . & & $44,537,063$ & $36,115,241$ & $54,854,242$ & $51,576,653$ \\
\hline Value $£$ sterling & .. & .. & $2,001,046$ & $1,890,585$ & $4,956,887$ & $3,632,230$ \\
\hline
\end{tabular}

The State of Pará is next in iniportance, but comes far behind Bahia. Maranhão, Ceará, Pernambuco, Esperito Santo, the Federal District and São Paulo produce very suall quantities.

The cocoa zone lies between the $23^{\circ}$ lat. $\mathrm{N}$. and $22^{\circ}$ lat. S., a mean temperature of $2+$ to $28^{\circ} \mathrm{C}$. is necessary ; rich loany soil and dampness are two further requirements. The municipality of Nazareth in the southern part of Bahia seems to be the centre of cocoa cultivation. 500 trees are planted per hectare which allows catch-crops, such as Mandioc, Indian corn, etc., being planted between the rows. The trees are allowed to fruit in the fourth year, in the sixth they give an average crop and increase up to the twelfth year. The tree lasts about 25 years; it is from 6 to 8 metres high, and the fruit forms directly on the stem, generally several are grouped together. One 
often sees fruit and blossom on the tree together; it takes nine months for the formation of the fruit. The cocoa beans are embedded in a 5-cornered oblong eapsule, each of which has about 25 beans. The beans are fermented generally during four days and are then dried and ean be kept in this state for years. The work connected with cocoa cultivation is of the simplest kind and easy to perform.

Brazil produces the fifth part of the world's cocoa requirements.

Rubber from the Amazonas, Acre and Pará was, before the arrival of plantation rubber, the wealth of these States, but in view of the rapidly increasing yields of the plantations of the British eolonies, it is hardly to be expected that Brazil ean compete unless thorough reforms are carried out. The output of the world's plantation rubber has grown as follows:--

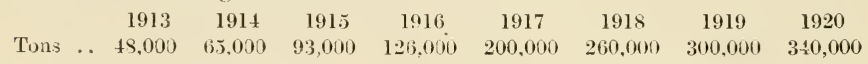

In 1920 Brazil s exports amounted to only 23,352 tons, as is shown in the following table :-

\begin{tabular}{|c|c|c|c|c|c|c|c|c|c|c|}
\hline \multirow{2}{*}{ STATES } & \multirow{2}{*}{\multicolumn{2}{|c|}{ PORTs }} & \multicolumn{4}{|c|}{ KILOS } & \multicolumn{4}{|c|}{ POUNDS STERLING } \\
\hline & & & 1917 & 1919 & 1919 & 1920 & 1917 & 1918 & 1919 & 1920 \\
\hline Amazonas & $\ldots$ & Manàos .. & $11,039,112$ & $8,260,724$ & $14,035,677$ & $11,727,177$ & $3,454,898$ & $1,520,432$ & $2,521,796$ & $1,936,382$ \\
\hline , & . & Itacoatiara. & 30,870 & -5 & 111,548 & 114,312 & $7,3+7$ & - & 22,811 & 20,667 \\
\hline Jará $\quad \cdots$ & . & Betén ... .. & $16,844,573$ & $13,523,585$ & $17,763,924$ & $10,930,862$ & $3,494,396$ & $2,302,118$ & $3,186,662$ & $1,647,401$ \\
\hline Maranhão & .. & 5. Luiz . . & 42,307 & 16,852 & 42,910 & 9.633 & 9712 & 3,150 & 12,051 & 1,291 \\
\hline , & * & $\begin{array}{c}\text { Hha do Ca- } \\
\text { jueiro .. }\end{array}$ & $188,51 \mathrm{Q}$ & 47,357 & 95,962 & $18: 3,609$ & 29,051 & $10,926 i$ & $9,39.9$ & 24,980 \\
\hline Pahia $\because$ & & S. Salvailor... & $1,058,396$ & 233,765 & $33+, 150$ & 237,205 & 135,707 & 26,572 & 44,464 & 22,829 \\
\hline Feuerat Disth & & neiro. & 283,277 & 81,944 & 87,929 & 1,882 & 79,071 & 24,373 & 21,424 & 192 \\
\hline São Paulo & .. & Santos: & 89,050 & 68,320 & 333 & 1,602 & 14,335 & 18,211 & 66 & 204 \\
\hline Matto Grosso & ... & Corumbá .. & 524,567 & 272,101 & 247,102 & 145,974 & 124,380 & 65,375 & 55,124 & 31,459 \\
\hline- & & Other ports.. & 897,455 & 157,039 & 532,709 & - & 135,273 & 26,513 & 62,999 & 30,354 \\
\hline
\end{tabular}

The collection of the wild rubber in the distant forests in Amazonas and Pará seems to be unprofitalble owing to the high cost of living. Everything required for the sustenanee of the "seringueiros" as the rubber gatherers are called, has to be imported and it is often eheaper to import even food from the Argentine and Europe than transport it from Brazilian ports. Some plantations have been started in Brazil. The following is an extract from a recently published Brazilian Government report :-

"The Hevea Braziliensis is met with in its native state in the Acre Territory and in Amazonas, Pará and Matto Grosso. There are at present numerous plantations in a very prosperous condition in Maranhão, Piauhy, Ceará, Parahyba do Norte, Bahia, Esperito Santo and Rio de Janeiro. This tree produces excellent rubber.

"The Maniçoba is found wild in vast areas of Maranhão, Piauhy, Ceará, Bahia, Minas Geraes, Goyaz and Paraná. It is cultivated on a small scale in Rio Grande do Norte, Parahyba, Pernambueo, Alagôas and Sergipe. 
" The Caucho or Castillô is met with in the Amazon valley and in Parí. It is thought by some planters to be one of the most important of the rubber-yielding species.

"The Mangubeira grows throughout the region comprised betwcen the upper Acre and the further extremity of Paraná. Its culture has been attempted in other States, but has subsequently been abandoned, owing to the smali yields in comparison with the other species."

Herva Maté, the green tea of Suth America, aceounts for nearly $\$ 3,000,000$ in the list of exports; it is obtained from the leaves and twigs of "ilex maté," "ilex paraguavensis." The tree resembles an orange tree, is about eight metres in height, the leaves are oblong. The most important State for " maté " is Paraná, then follows Matto Grosso. Rio Grande do Sul. ete. It is rstimated that $50,(m u), 000$ kilos of maté are consumed anmually, three-fifths of which is produced in Paraná.

Maté tea is a stimulant tonic, mildly laxative and much appreciated by Brazilians, Argentines and Chilians, as a hot or a cold dirink. The tea is generally served in a bowl (" enia "= the sheli of a gourd) into which a small tube ("bomba") is admitted. The "cuia" and "bomba " are passed from one to another, but in the cities "maté" is served like ordinary tea in eups.

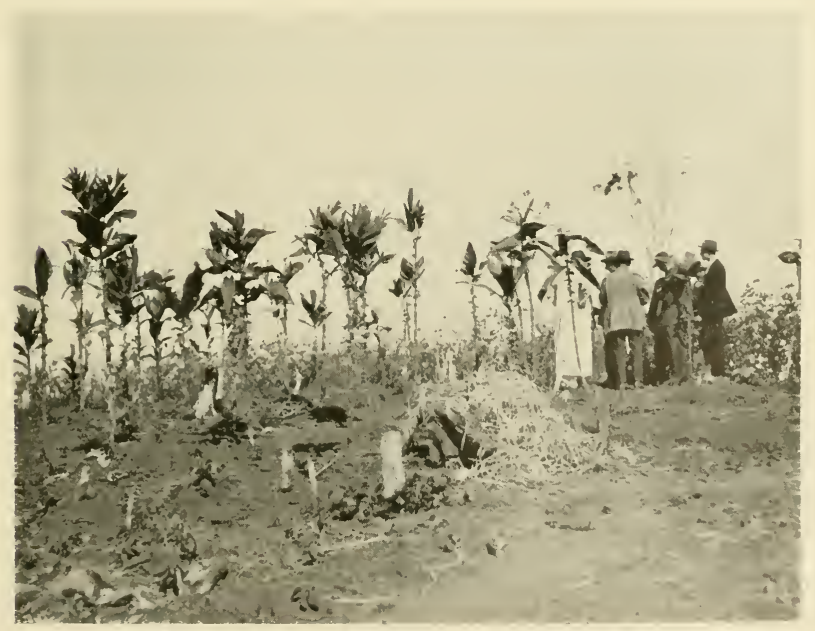

Tobacco Plants at Villa Americana (São Paulo)

Notice the extraordinary height which the plants attain

Tobacco is the last of the ten chief articles of cxport. The State of Bahia exported in 1919 38,123,336 kilos. representing a value 
of $₫ 3,702,953$, in 1920 this quantity fell almost $10,000,000$ kilos. Rio Grancle do Sul is the next largest exporting State with an average of about 2,000,000 kilos. Good tobacco is grown also in Vlinas, Goyaz, São Paulo, and practically in every State, but this is more for home consumption. In the north of Brazil women smoke pipes, whilst the men keep to cigarettes which they make with the leaf of Inclian corn in place of paper.

The largest buyer of Brazilian tobaceo before the War was Germany ; in 1912 Germany took 19,236,000 kilos, equivalent to twothirck of the total exports.

São Felix in Baliia is the centre of the tobacco manufacture; for the cover-leaf of cigars tobacen from Sumatra and Cuba is still leing inporterl. merely because the Brazilian tobacco is not carefull! graded.

It is noteworthy to remember that in the central and north Brazil the word tobacco is not used, but "fumo."

Cereals.-WHEAT is little grown in Brazil and most of the country's requirements ( 600,000 tons) are imported from Argentine. In the Portuguese colonial times the southern States, such as Rio Grande rlo Sul, Santa Catharina and Paraná used to grow wheat, but owing to various diseases the cultivation was abandoned. The Government has recognised the wisclom of reintroducing this crop, and by means of premiums it is assisting successfully. Rio Grande do Sul, São Paulo and Minas have again commenced to grow wheat and it was estimater that the country produced 84,009 tons in 1917 , 200,000 tons in 19:0); half of this was grown in Rin Grande do Sul.

RICE is grown in every part of Brazil and the primitive cultivation is slowly making room for improverl methods, especially in Pio de Janeiro, São Paulo, Minas, Rio Grande do Sul and Paraná. In the north three crops of rice may be harvester in one year.

Whilst in 1915 rice exports amounter to only three tons, in 1920 they hat reachel 135,000 tons, representing a value of almost f6,000,00m). Rice is largely consumed in Brazil mixed with beans, mandioca, jerked bcef, etc, which constitutes the national dish called "feijoarla."

The exports for the last few years were:-

\begin{tabular}{|c|c|}
\hline & \\
\hline Gilos & . \\
\hline 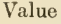 & . \\
\hline
\end{tabular}

Buans are considered cereals in Brazil. The black bean ("feijão preto") is the staple food of the masses and is grown everywhere. The War has made Brazilian beans popular in most parts of the world, especially the brown bean ("feijão mulatinho"). For export purposes beans are frequently sterilised with a view to killing any insects which might reduce the value of the shipment in transit. It is roughly calculated that Brazil prorluces anmually the large quantity of 350,000 tons of beans. The exports during the last few years were :-

\section{7}

Kilos

Value
1918

$92,851,909$ $£ 1,689,284$
1919

$44,815,403$

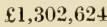

1920 
The U.S.A. are ready to take any surplus from Brazil.

InImAN Corn (Maize). This is grown in some 20 varieties in most parts of the country, generally as a catch crop, as for instance in cotton fields. Indian corn is largely consumed locally, but since $1916 \mathrm{i}$ exportation has hegun: the following are the figures:-

\begin{tabular}{|c|c|c|c|c|c|c|}
\hline & & & 1917 & $191 \mathrm{~s}$ & 1919 & 1920 \\
\hline Kilos & $\ldots$ & .. & $24,054,425$ & $14,275,450$ & $3,475,400$ & $4.426,223$ \\
\hline Value & .. & .. & $£ 209,849$ & $£ 195,049$ & f50039 & $£ 53.392$ \\
\hline
\end{tabular}

Mandioca, a root crop, recuires to be mentioned on account of the popularity which it has attained in Europe during the last few rears. Mandioca or mandioc, as it is sometimes ealled (in Latin "manihot utilissima, euphorbiaees,") is closely related to the maniçoba rubber tree. The name is derived from Indian, " mandi" meaning bread and "oca " house. Indeed it is to the present day largely used as substitnte for bread and on our journeys in the interior, along the São Francisco river and the north-eastern States, we rarely had hread to eat, always the "farinha" or mandioca flour. Up country many people sprinkle all kinds of food with this flour which one finds invariably on the table.

The cultivation is very simple. A tuber is planted in AugustSeptember, it grows very rapidly; in Narch the tree is 4 to 5 feet high and flowers begin to show which is an indication that the root is ripe. No weeding is required, as the tree soon spreads a close shade. As with several Brazilian crops, it is merely a question of planting and harvesting. One root may weigh up to 25 kilos. We saw the most luxuriant mandioca plants along the São Franciseo river. The root is prepared in the following manner : it is cleaned, washed, ground, pressed and roasted; in this way the poisonous ingredients of the plant disappear.

Mandioca is used in the preparation of tapioca or Brazilian sago.

Exports of mandioca flour from 1913/16 fluctuated hetween 4,177 and 4,771 tons, but in 1917 they reached 18,489 tons and in 1918 , 25,000 tons. Italy has taken large quantities of this commodity; most of the foreigners in Brazil like this typical Brazilian product in their meals.

Carnauba Wax.-During one of the breakdowns of our motors we had the pleasure of discussing with a number of small farmers in the Carnauba Palm district near Assú, the method of obtaining the wax. As this wax is being more and more used in the manufacture of gramophone records, in the making of dyes and size and as little is known of this primitive industry, the following notes may be of interest. These small farmers said: The Carnauba palms belong to those rich men who let out small lots to the poor people who pay the rent in wax after the year's crop, the annual charge depending on the value of the palm trees. No contract is made for longer than one year but the old tenant always has preference over the area which he had hired the previous year. During the year the landowner, who has generally a shop, advances to his small tenants cash and the necessities of life. 


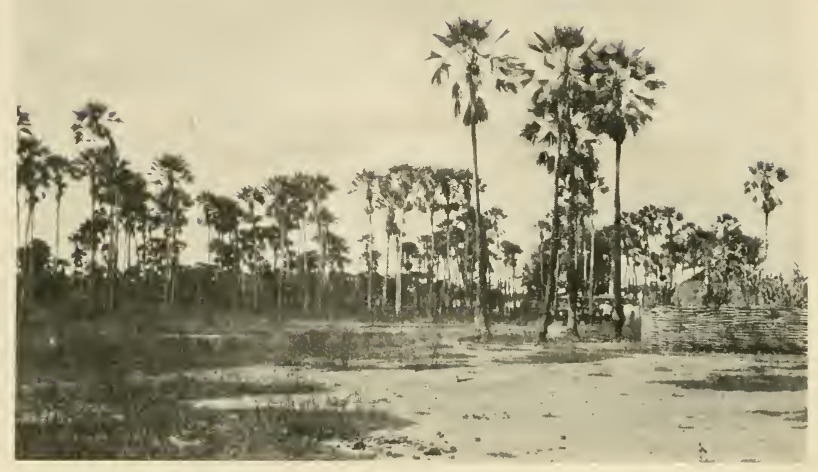

Carnauba Palms near Assú

One Carnauba tree gives from 10 to 14 leaves ("palhas") at the first cutting ("corte"), and five to six leaves at the second cutting. Generally three cuttings are made, the first in Oetober, the second in December, and the third in February. The latter is sometimes omitted if rains set in. Four trees give about 100 leaves in the year and from 100 leaves is produced, more or less, one kilo of wax.

The leaves are classified into "palhas" and "olhos" (eyes). "Palhas" are the fully opened-up fan-shaped leaves, whilst " olhos" are the young bright green leaves, standing upright and not yet opened up. The latter provide the best quality. Great eare must be exercised in separating the young leaves from the old ones before preparing them.

The leaves are eut from the high trees by means of a knife (" clinchete" or "foiee ") attaehed to a long pole ("vara ") composed of various lengths, each of which has a name, viz. : "pé da vara," the bottom length, "macaco" the second, "soin" the third, "guariba" the fourth, "creseentão" the fifth and "emmenda" the sixth. Two people will cut, collect and spread out 2,000 leaves in 12 hours. The leaves are dried in the sun during four days, when they are taken into a shed (" estalleiro") and slashed by a man into long strips and beaten by a woman. 2,000 leaves are treated in this way in 12 hours. The dust falling out from the ent leaves is taken in a clay bowl ("caco de barro") over a fire, where it is soaked with some water, or when the dust is put into the bowl in a dry state, it is: heated to melting point. In both cases the wax, whilst still hot, is filtered. The caked wax is packed in strong jute bags.

This primitive method of extracting the wax ought to be replaced by some more adranced mechanical means. 
The wax is graded into " Cera de 1.", "Cera de 2." and " Cera Mediana "for which the local prices at the time of our visit (July: 1921 ) were $50 \$ 000,30 \$ 000$, and 208000 per unit.

Everything is used of the Carnauba palm.

(1) The leaves after the extraction of the dust are given to the cattle; houses are lined inside with the leaves and hats and various paddings are made of them.

(2) The small black seed is much appreciated by man and animals.

(3) The stem (pau) is excellent material in the construetion of houses, fences, etc.

(4) The root is used in the preparation of medicine.

(5) The wax, besides being a commodity of export greatly in demand, is used as an illuminant in the houses. (Often our only lamps were small, open, flat, iron basins with a wick and dissolved Carnauba wax.)

Carnauba palms grow wild in marshy land ("lama ")--such as is depicted in the bottom pictures on page 137-and low-lying margins of rivers ("varzeas").

Besides the above work no further attention is required and Carnaubas therefore provides an ideal occupation for lazy people, similar to Mandioca. Indeed, nature has been too lind to Brazil : most products grow with little or no help on the part of the people; no wonder that they are at times indolent.

Mining.-The following is a statement by Mr. Orville Derl,y, Director of the Geological Govermment Service at Rio de Janeiro, which gives a short general resumé such as might interest the reader:-

1.-Gold miming.-- It Sabará and Ouro Preto, in the central part. of Minas Geraes, there are two large mining enterprises and a number of smaller ones, to which we are indelsted for nearly all the gold exported from Brazil, which amounts to about 4,000 contos de reis (gold) $(2,2 \cdot 22,000$ dollars $)$. In this and several other distriets of the same and other States, a certain amomnt of gold is produced owing to the intermittent labours of isolated miners, called faiscadores, operating in alluvial deposits, hut as this gold enters the local circulation. its ralue, which certainly cannot be rery great, escapes computation.

B.-Diamond mining.-Diamond mining has been on the decline since 1872 , when the vield of South Africa becance so great as to supplant it, hut it is still carried on in the districts of Diamantina and Bagagem, in the State of Minas Geraes and in those of the Chapada, Diamantina and Camavieiras, in the State of Bahia. The official value of diamonds exporter through the custom houses of Rio de Janeiro and Bahia, in 1912. was about 2, 50 contos de reis (138.010) dollars), hut there is no doubt that the total ralue of the production was far above this figure.

C.-Carbonate mining.-This is limited to the diamond region of the central part of Bahia. The official value of exportation through the custom house of Bahia, in 191:, was a little orer 86 contos de reis in gold $(47,700$ dollars $)$. 
D.-Manganese mining.--There are several mines in active exploitation in the municipalities of Onro Preto and Queluz, in the State of Minas Geraes. These mines have yielded during several years past, an annual mean production of about 200,000 tons. Another centre of production is the municipality of Nazareth, in the State of Bahia; but this work is stopperl at present. During the period in which these mines were worked, the yield was several score of thousands of tons per annum.

E.-Iron mining.-The enomuous beds of first-class iron, which exist in the eentral part of Minas Geraes, in the districts of Ouro Preto, Sabarn, Itabira do Matto Dentro and others, have given rise to a number of gigantie projeets of mining on a grand scale, both for the production of iron in the country and for the exportation of the ore, but up to the present, none of them have begun operations, and actual mining is confined to the Esperança Works, near the eity of Italira do Campo, which produces a few score of tons per day.

F.-Copper mining.-Beds of eopper are known in the States of Rio Grande do Sul, Bahia and Maranhão, but only in the first of these States have attempts been made to exploit them on a small scale. It appears that even these have been discontinued, as no shipping is reeorded for 191:2 through the port of Rio Grande.

G.-Monazitic Sand mining.-The extraction of monazitic sant is at present confined to the original beds of maritime origin lying along the eoast from the State of Bahia to the north of Rio de Janeiro. The mining of river beds at several places in the interior has been discontinued for some years. The exportation in 1912 through the ports of Bahia. Victoria and Rio de Janeiro. was 3,395 tons, at the official value of 965 eontos and a half (gold) $(536,350$ dollars).

H.--Coal mining.-This is confined to one single mine, situated in the inunicipality of São Jeronymo, in the state of Rio Grande do Sul, which, for a number of years, has yielded an annual production of several thousand tons.

I.--Nining of Precious Stones.-Yellow topazes are mined in the district of Ouro Preto, in the State of Vinas Geraes; white, green and blue topazes, aquamarines and turmalines, in the district of Theophilo Ottoni and neighbouring ones, in the eastern part of the State. The official exportation for 1912 was estimated at 133 contos 956 milreis in gold $(74,4 \geqslant 0$ dollars $)$.

I. - Igrte mining. - This is carried on at several places in the State of Rio Grande do Sul. The exportation, in 1914, was 103 tons, valued at 82 contos 198 milreis alout $(45,660$ dollars $)$.

K.-Mining of Rocle Crystal.- This is confined to the district of the Serra dos Crystaes, in the State of Goyaz. The exportation, in 1912, was 45 tons, estimated at 56 contos 368 milreis in gold $(31,315)$. 


\section{BRAZILIAN INDUSTRIES}

The industrial movement has developed to a great extent during the last 20 vear's, especially in the Federal District and São Paulo, Rio de Janeiro, Rio Grande do Sul, etc. The following table shows the distribution of factories per State, the capital employed and number of workpeople :-

\begin{tabular}{|c|c|c|c|c|c|c|}
\hline \multicolumn{3}{|c|}{ STATES } & $\begin{array}{c}\text { NUMBER OF } \\
\text { LARGE ESTAB- } \\
\text { LISHMENTS }\end{array}$ & $\begin{array}{l}\text { CAPITAL IN } \\
\text { MILREIS }\end{array}$ & $\begin{array}{l}\text { PRODUCTION IN } \\
\text { MILREIS }\end{array}$ & $\begin{array}{l}\text { NUMBER OF } \\
\text { WORKMEN }\end{array}$ \\
\hline Alagôas & . & .. & 47 & $10,937: 887 \$ 000$ & $10,496: 310 \$ 000$ & $3.3 \tilde{5}$ \\
\hline Amazonas & & & 93 & $6,484: 000 \$ 000$ & $14,962: 000 \$ 000$ & 1,267 \\
\hline Bahia . & .. & . & 83 & $28,377: 200 \$ 000$ & $25,990: 962 \$ 000$ & 10,009 \\
\hline Ceará .. & & . & 24 & $6,484: 000 \$ 000$ & $3,422: 500 \$ 000$ & 11,353 \\
\hline Districto Feo & deral & . & 895 & $188,442: 259 \$ 000$ & $255,164: 542 \$ 000$ & 40,331 \\
\hline Espirito San & & .. & 8 & 1,251:000\$000 & $1,209: 500 \$ 000$ & 400 \\
\hline Goyaz. & .. & .. & 135 & $1,618: 000 \$ 000$ & $2,471: 000 \$ 000$ & 868 \\
\hline Maranhão & .. & . & 19 & $13,540: 250 \$ 000$ & $7,640: 332 \$ 000$ & 4.59 .5 \\
\hline Matto Gress & 0 . & . & 16 & $13,650: 00$ & 4,450:000\$000 & 3,870 \\
\hline Pará ... & $\cdots$ & .. & 55 & $11,503: 000 \$ 000$ & $18,223: 000 \$ 000$ & 2,544 \\
\hline Parahyba do & Nort & e.. & 43 & 4,990:500\$000 & 4,394:912\$000 & 1,465 \\
\hline Paraná & & & 302 & $21,152: 000 \$ 000$ & $33,940: 294 \$ 000$ & 4,824 \\
\hline Minas Gerae & & .. & 552 & $29,307: 372 \$ 000$ & $36,190: 694 \$ 000$ & 10,091 \\
\hline Pernambuco & .. & .. & 126 & $60,229: 000 \$ 000$ & $57,676: 293 \$ 000$ & 12,388 \\
\hline Piauhy & & .. & 3 & $1.310: 878 \$ 000$ & $975 \$ 000$ & 355 \\
\hline Rio Grande & do No & rte & 43 & 6,921:000\$000 & $3,094: 485 \$ 000$ & 2,063 \\
\hline Pio Grande & do $\mathrm{Sn}$ & & 328 & $47,448: 919 \$ 000$ & $102,678: 820 \$ 000$ & 15,907 \\
\hline Rio de Jane & iro & & 248 & $86,830: 457 \$ 000$ & $0: 86 . \$ \$ 000$ & 13,994 \\
\hline Santa Catha & rina & . & 174 & 9,689:000\$000 & $14,169: 410 \$ 000$ & 2,106 \\
\hline São Paulo & . & . & 384 & $166,057: 191 \$ 000$ & $78: 0215000$ & 33,252 \\
\hline \multirow[t]{2}{*}{ Sergipe } & $\cdots$ & . & 103 & $14,172: 858 \$ 000$ & 14,81 I:105\$000 & 3,027 \\
\hline & & & 3,664 & $727,719: 771 \$ 000$ & $811,798: 008 \$ 000$ & 168,764 \\
\hline
\end{tabular}

Besides the cotton spinning and manufacturing industry, which are dealt with in Chapter ii. in the book, there are factories for manufacturing wool, cigars, cigarettes, beer, wine, rum and other forms of alcohol, maize and mandioca farinhas, shoes, carriages, railway wagons, diamond grinding, matches, ropes, cheese, butter, jerked beef, chilled and frozen meat, preserves, chocolates, oil, vinegar, tea, maté, salting of fish, gum elastic, hats, crockery and earthenware, varnished leather and inoroceo, glassware. 


\section{BRAZILIAN RATE OF EXCHANGE AT 90\% FOR THE YEARS 1919, 1920, AND 1921.}

(expressed in pence per one milieis).

\begin{tabular}{|c|c|c|c|c|c|c|c|}
\hline Dates & & & 1919 & & 1920 & & 1921 \\
\hline January & 7 & $\ldots \ldots \ldots$ & $13 \frac{1}{1}$ & $\ldots \ldots \ldots \ldots$ & $17 \frac{7}{8}$ & $\ldots \ldots \ldots \ldots$ & $10 \frac{2}{16}$ \\
\hline , & 14 & $\ldots \ldots \ldots$ & $13 \frac{1}{8}$ & $\ldots \ldots \ldots \ldots$ & $17 \frac{13}{16}$ & $\ldots \ldots \ldots \ldots$ & $10^{16}$ \\
\hline ,. & 21 & $\ldots \ldots \ldots$ & $13 \frac{1}{8}$ & $\ldots \ldots \ldots \ldots$ & $17 \frac{10}{8}$ & $\ldots \ldots \ldots \ldots$ & $9 \frac{3}{8}$ \\
\hline ," & $2 s$ & $\ldots \ldots \ldots$ & $13 \frac{3}{16}$ & ......... & $17_{4}^{3}$ & $\ldots \ldots \ldots \ldots$ & $9_{1}^{3}$ \\
\hline February & 4 & $\ldots \ldots \ldots$ & $13 \frac{1}{4}$ & $\ldots \ldots \ldots \ldots$ & $18 \frac{1}{4}$ & $\ldots \ldots \ldots \ldots$ & $9 \frac{3}{4}$ \\
\hline , & 11 & $\ldots \ldots \ldots$ & $13 \frac{1}{s}$ & $\ldots \ldots \ldots \ldots$ & $18 \frac{1}{4}$ & $\ldots \ldots \ldots \ldots$ & $9 \frac{1}{2}$ \\
\hline , & 18 & $\ldots \ldots \ldots$ & $13 \frac{1}{8}$ & n......... & $18 \frac{1}{2}$ & n......... & $10_{8}^{3}$ \\
\hline , & 25 & $\ldots \ldots \ldots$ & $13 \frac{1}{1}$ & n......... & $18 \frac{1}{2}$ & ........... & 10 \\
\hline Narch & 4 & $\ldots \ldots \ldots$ & 134 & n.m. & $18_{4}^{1}$ & $\ldots \ldots \ldots$ & $10 \frac{1}{8}$ \\
\hline , & 11 & $\ldots \ldots \ldots$ & $33 \frac{5}{16}$ & $\ldots \ldots \ldots \ldots$ & $17 \frac{1}{4}$ & $\ldots \ldots \ldots$ & $9 \frac{1}{1}$ \\
\hline ", & 18 & $\ldots \ldots \ldots$ & $13 \frac{10}{16}$ & n........ & $17 \frac{9}{16}$ & $\ldots \ldots \ldots$ & $9 \frac{1}{2}$ \\
\hline , & 25 & $\ldots \ldots \ldots$ & $13 \frac{\overline{2}}{16}$ & $\ldots \ldots \ldots \ldots$ & $16 \frac{3}{4}$ & $\ldots \ldots \ldots$ & $9 \frac{1}{2}$ \\
\hline April & 1 & $\ldots \ldots \ldots$ & $13 \frac{10}{2}$ & $\ldots \ldots \ldots \ldots$ & $16 \frac{7}{4}$ & $\ldots \ldots \ldots \ldots$ & 9 \\
\hline " & s & $\ldots \ldots \ldots$ & $13 \frac{\pi}{2}$ & ......... & $16 \frac{1}{2}$ & ......... & $8 \frac{1}{2}$ \\
\hline , & 15 & $\ldots \ldots \ldots$ & $13_{1}^{3}$ & .......... & $16 \frac{2}{4}$ & .......... & $8 \frac{3}{5}$ \\
\hline ,. & 22 & $\ldots \ldots \ldots$ & $14^{1}$ & $\ldots \ldots \ldots \ldots$ & $16 \frac{4}{8}$ & $\ldots \ldots \ldots \ldots$ & $8 \frac{3}{4}$ \\
\hline.. & 29 & $\ldots \ldots \ldots$ & $14 \frac{1}{3}$ & $\ldots \ldots \ldots \ldots$ & $16 \frac{1}{2}$ & $\ldots \ldots \ldots \ldots$ & 81 \\
\hline May & 6 & $\ldots \ldots \ldots$ & $14 \frac{9}{16}$ & n......... & $16_{8}^{5}$ & ........... & $8 \frac{1}{8}$ \\
\hline . & 13 & $\ldots \ldots \ldots$ & $14 \frac{1}{1}$ & n......... & $16 \frac{5}{5}$ & .......... & $8 \frac{5}{16}$ \\
\hline .. & 20 & $\ldots \ldots \ldots$ & $14 \frac{3}{4}$ & n.w. & $16 \frac{9}{16}$ & $\ldots \ldots \ldots$ & $8 \frac{1}{2}$ \\
\hline , & 27 & $\ldots \ldots \ldots$ & $14_{8}^{5}$ & n....... & $16 \frac{1}{4}$ & $\ldots \ldots \ldots \ldots$ & $8 \frac{1}{2}$ \\
\hline June & 4 & $\ldots \ldots \ldots$ & $14 \frac{9}{16}$ & $\ldots \ldots \ldots$ & $15_{8}^{5}$ & $\ldots \ldots \ldots \ldots$ & $8 \frac{3}{8}$ \\
\hline " & 11 & $\ldots \ldots \ldots$ & 145 & n...... & $15 \frac{3}{8}$ & $\ldots \ldots \ldots \ldots$ & $8 \frac{1}{8}$ \\
\hline , & 18 & $\ldots \ldots \ldots$ & $14 \frac{5}{8}$ & $\ldots \ldots \ldots \ldots$ & $14_{8}^{5}$ & $\ldots \ldots \ldots \ldots$ & 71 \\
\hline , & 25 & $\ldots \ldots \ldots$ & $14_{+}^{3}$ & .......... & $14 \frac{1}{2}$ & .......... & $7 \frac{1}{16}$ \\
\hline July & 2 & $\ldots \ldots \ldots$ & $14 \frac{5}{8}$ & $\ldots \ldots \ldots \ldots$ & $14_{8}^{5}$ & $\ldots \ldots \ldots \ldots$ & $7 \frac{1}{16}$ \\
\hline$"$ & 9 & .......... & $14 \frac{7}{16}$ & ........... & $14 \frac{9}{16}$ & $\ldots \ldots \ldots \ldots$ & $7 \frac{1}{16}$ \\
\hline , & 16 & $\ldots \ldots \ldots$ & 145 & .......... & $14 \frac{1}{4}$ & $\ldots \ldots \ldots \ldots$ & $7 \frac{1}{8}$ \\
\hline " & 23 & $\ldots \ldots \ldots$ & $14 \frac{11}{16}$ & n.m. & $14 \frac{1}{8}$ & $\ldots \ldots \ldots$ & $7 \frac{3}{8}$ \\
\hline , & 30 & $\ldots \ldots \ldots$ & $14_{4}^{5}$ & $\ldots \ldots \ldots$ & $14 \frac{1}{8}$ & $\ldots \ldots \ldots \ldots$ & 81 \\
\hline Angust & 6 & $\ldots \ldots \ldots$ & $14 \frac{3}{2}$ & n........ & 14 & n....... & 8 \\
\hline " & 13 & $\ldots \ldots \ldots$ & $14_{1}^{i}$ & $\ldots \ldots \ldots \ldots$ & 14 & $\ldots \ldots \ldots \ldots$ & 81 \\
\hline .. & 20 & $\ldots \ldots \ldots$ & $14 \frac{3}{8}$ & $\ldots \ldots \ldots \ldots$ & $13 \frac{1}{2}$ & $\ldots \ldots \ldots \ldots$ & 8 \\
\hline , & 27 & $\ldots \ldots \ldots$ & $14 \frac{3}{\mathrm{~g}}$ & n.m. & $13 \frac{1}{2}$ & $\ldots \ldots \ldots \ldots$ & $7_{4}^{3}$ \\
\hline September & 3 & $\ldots \ldots \ldots$ & $14 \frac{7}{16}$ & .......... & 13 & .......... & $8 \frac{1}{3}$ \\
\hline " & 10) & $\ldots \ldots \ldots$ & $14_{8}^{5}$ & $\ldots \ldots \ldots \ldots$ & 123 & $\ldots \ldots \ldots \ldots$ & $8 \frac{3}{8}$ \\
\hline " & 17 & .......... & $11_{5}^{5}$ & n........ & 125 & $\ldots \ldots \ldots \ldots$ & $8 \frac{3}{5}$ \\
\hline$"$ & 24 & $\ldots \ldots \ldots$ & $14 \frac{11}{16}$ & n......... & $12 \frac{3}{8}$ & n......... & $8 \frac{1}{2}$ \\
\hline October & 1 & $\ldots \ldots \ldots$ & $14_{4}^{3}$ & n......... & $12 \frac{3}{8}$ & n.m. & $8 \frac{1}{2}$ \\
\hline ," & 8 & $\ldots \ldots \ldots$ & $14 \frac{7}{8}$ & n....... & $12 \frac{1}{1}$ & n....... & $8 \frac{3}{8}$ \\
\hline , & 15 & $\ldots \ldots \ldots$ & $14 \frac{7}{8}$ & $\ldots \ldots \ldots \ldots$ & $11 \frac{1}{1}$ & $\ldots \ldots \ldots \ldots$ & 81 \\
\hline , & 22 & $\ldots \ldots \ldots$ & $1+\frac{13}{16}$ & n.w. & $12 \frac{1}{2}$ & n........ & 8 \\
\hline , & 29 & $\ldots \ldots \ldots$ & $14 \frac{15}{16}$ & n....... & 125 & n........ & $8 \frac{1}{8}$ \\
\hline November & i & $\ldots \ldots \ldots$ & $15 \frac{3}{8}$ & n....... & $12 \frac{3}{8}$ & $\ldots \ldots \ldots \ldots$ & 8 \\
\hline .. & 12 & $\ldots \ldots \ldots$ & $16 \frac{3}{8}$ & ........... & $11 \frac{3}{4}$ & .......... & $7 \frac{7}{8}$ \\
\hline , & 19 & $\ldots \ldots \ldots \ldots$ & $16 \frac{5}{8}$ & $\ldots \ldots \ldots \ldots$ & $11 \frac{1}{4}$ & $\ldots \ldots \ldots \ldots$ & $7_{1}^{3}$ \\
\hline, & 26 & $\ldots \ldots \ldots$ & 18 & n......... & $12 \frac{1}{8}$ & n........ & $8 \frac{1}{8}$ \\
\hline December & 3 & ......... & $17 \frac{1}{2}$ & n........ & $11 \frac{5}{8}$ & n......... & 8 \\
\hline " & 10 & $\ldots \ldots \ldots$ & $18 \frac{1}{8}$ & $\ldots \ldots \ldots \ldots$ & $11 \frac{1}{4}$ & n.m. & $7_{1}^{3}$ \\
\hline , & 17 & $\ldots \ldots \ldots$ & $17 \frac{1}{2}$ & $\ldots \ldots \ldots \ldots$ & $10 \frac{1}{1}$ & $\ldots \ldots \ldots \ldots$ & $7 \frac{1}{2}$ \\
\hline " & 24 & $\ldots \ldots \ldots$ & $17 \frac{3}{4}$ & $\ldots \ldots \ldots+$ & $10 \frac{1}{8}$ & $\ldots \ldots \ldots \ldots$ & $7 \frac{3}{8}$ \\
\hline$"$ & 31 & ......... & $17_{1}^{3}$ & n....... & 10 & $\ldots \ldots \ldots \ldots$ & $7_{s}^{3}$ \\
\hline
\end{tabular}




\section{APPENDIX}

List of Brazilian Cotton Mills, with particulars of Spindles, Looms, Capital, etc.

Address by Arno S. Pearse before the "Sociedade Nacional de Agricultura," Rio de Janeiro. (Synopsis of Impressions.)

Advertisements

Coloured Map of Brazil 


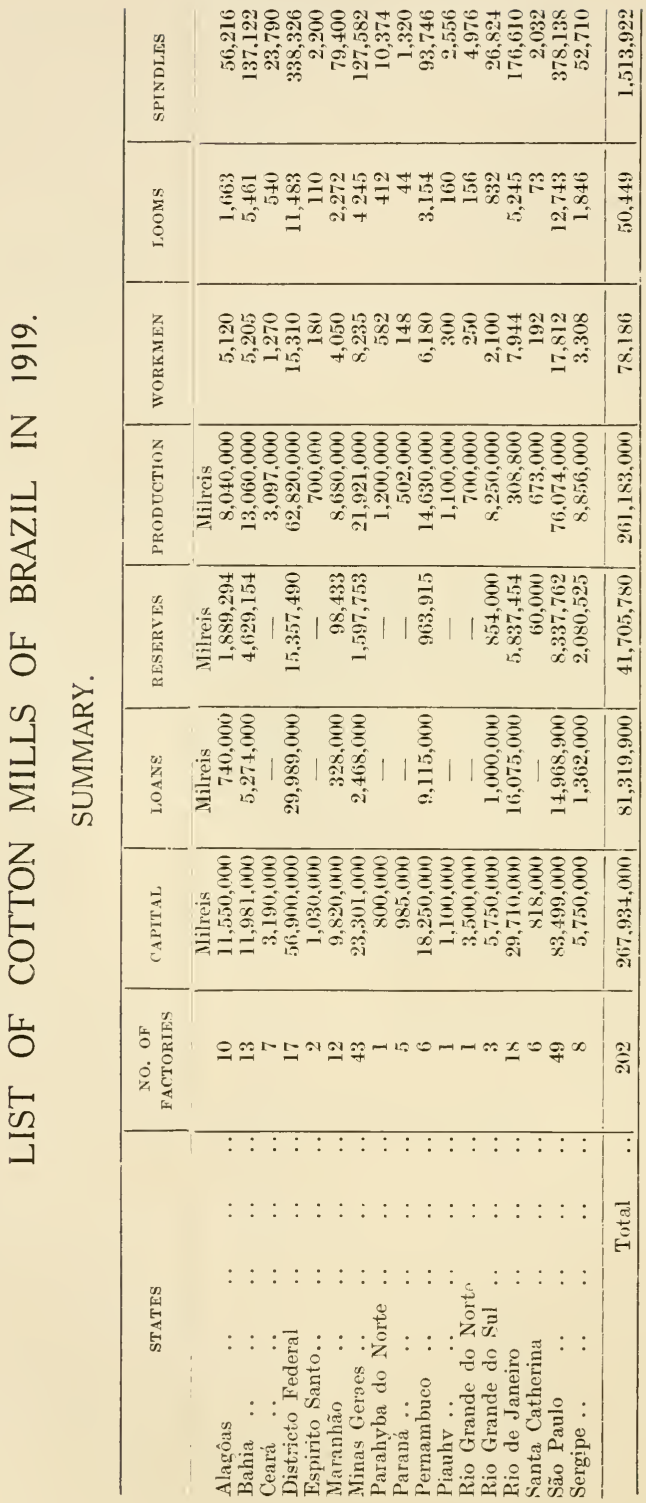




\begin{tabular}{|c|c|c|c|c|c|c|c|}
\hline 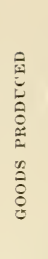 & 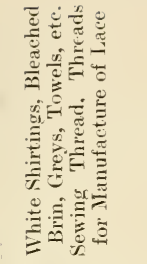 & $\begin{array}{l}c \\
\\
\end{array}$ & 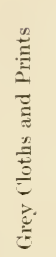 & 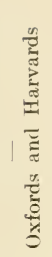 & 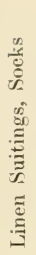 & 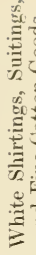 & \\
\hline 究参 & 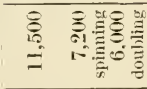 & 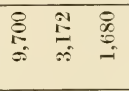 & $\begin{array}{l}0 \\
0 \\
10\end{array}$ & $\begin{array}{l}1 \\
\text { af } \\
\text { oi } \\
\text { oi }\end{array}$ & $\underbrace{8}_{0}$ & $\begin{array}{l}\infty \\
0 \\
\infty \\
\infty\end{array}$ & 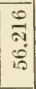 \\
\hline$\stackrel{5}{5}$ & $\S \approx$ & 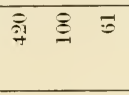 & ڤิ: & $1 ?$ & $\ddot{x}$ & 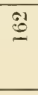 & $\int_{0}^{8}$ \\
\hline $\begin{array}{l}\frac{2}{2} \\
\frac{2}{2} \\
\frac{2}{2}\end{array}$ & $\frac{\overline{\bar{s}}}{x}$ & 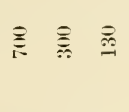 & $\S$ & 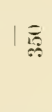 & $\overline{0}$ & 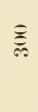 & $\underset{\frac{8}{20}}{-10}$ \\
\hline$\stackrel{2}{2}$ & 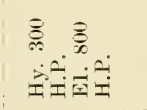 & 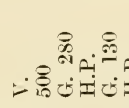 & . & 12 & 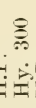 & & \\
\hline 我 & $\stackrel{\Xi}{\Xi}$ & 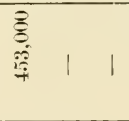 & 1 & 章 & 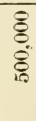 & 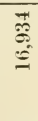 & $\begin{array}{l}+ \\
\text { i } \\
\infty \\
\infty \\
\infty \\
-1\end{array}$ \\
\hline$\frac{n}{2}$ & $\infty 1$ & 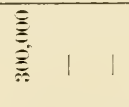 & 1 & 產 & I & 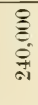 & $\begin{array}{l}\mathscr{g} \\
\stackrel{8}{1} \\
\end{array}$ \\
\hline 章 & 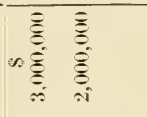 & 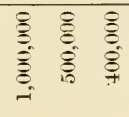 & $\underset{8}{8}$ & है & $\begin{array}{l}8 \\
5 \\
8 \\
20 \\
10 \\
\text { oi }\end{array}$ & 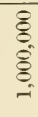 & $\begin{array}{l}8 \\
8 \\
8 \\
10 \\
= \\
=\end{array}$ \\
\hline 吾 & 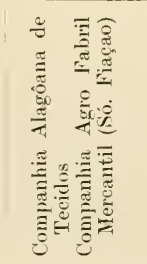 & 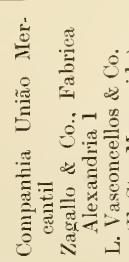 & 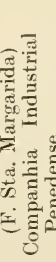 & 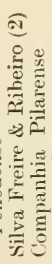 & 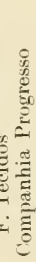 & 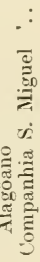 & \\
\hline 岂 & 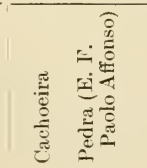 & 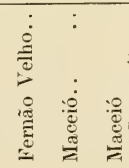 & 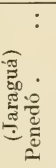 & 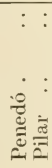 & ํㅗㄱ & 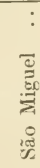 & \\
\hline
\end{tabular}




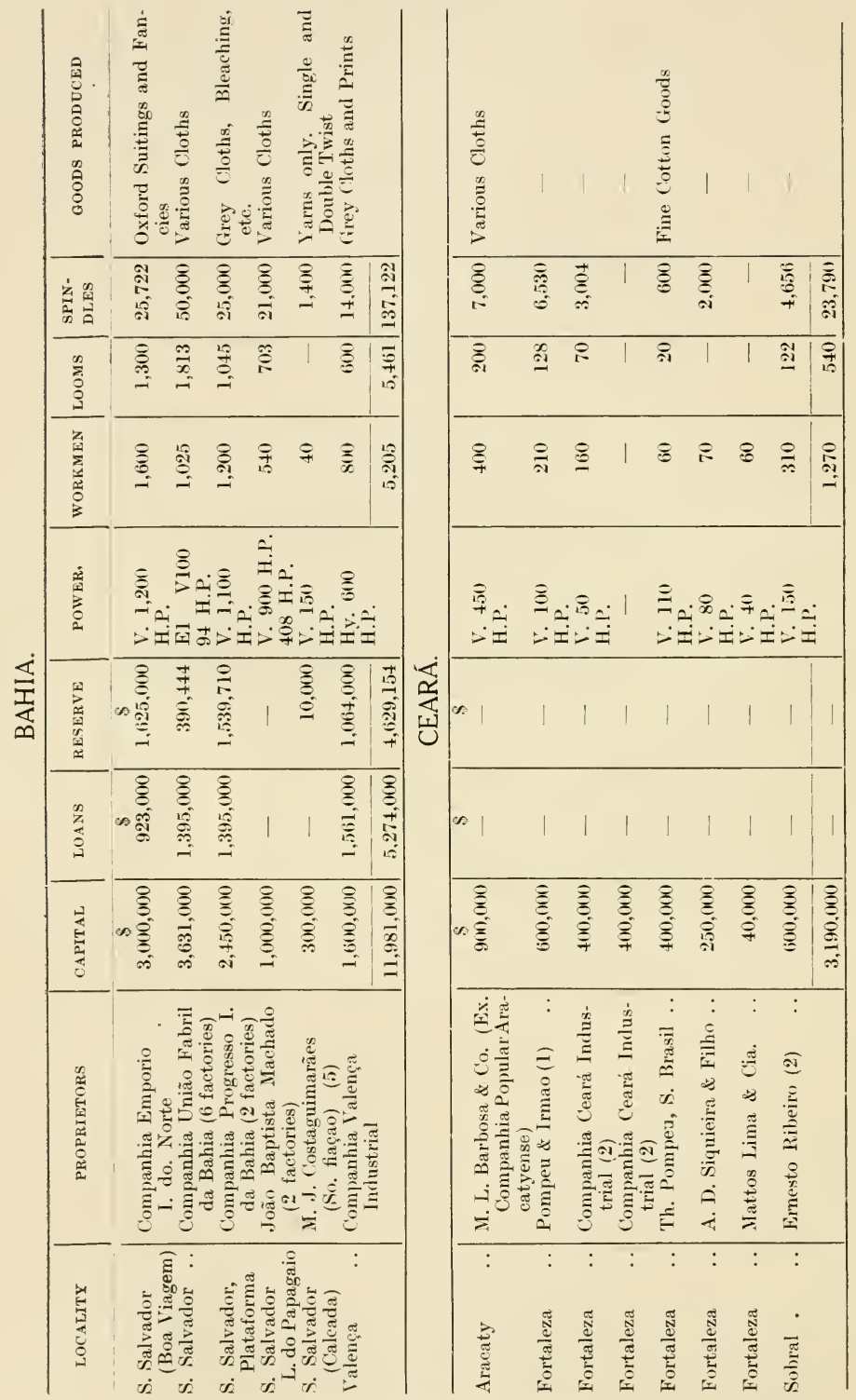




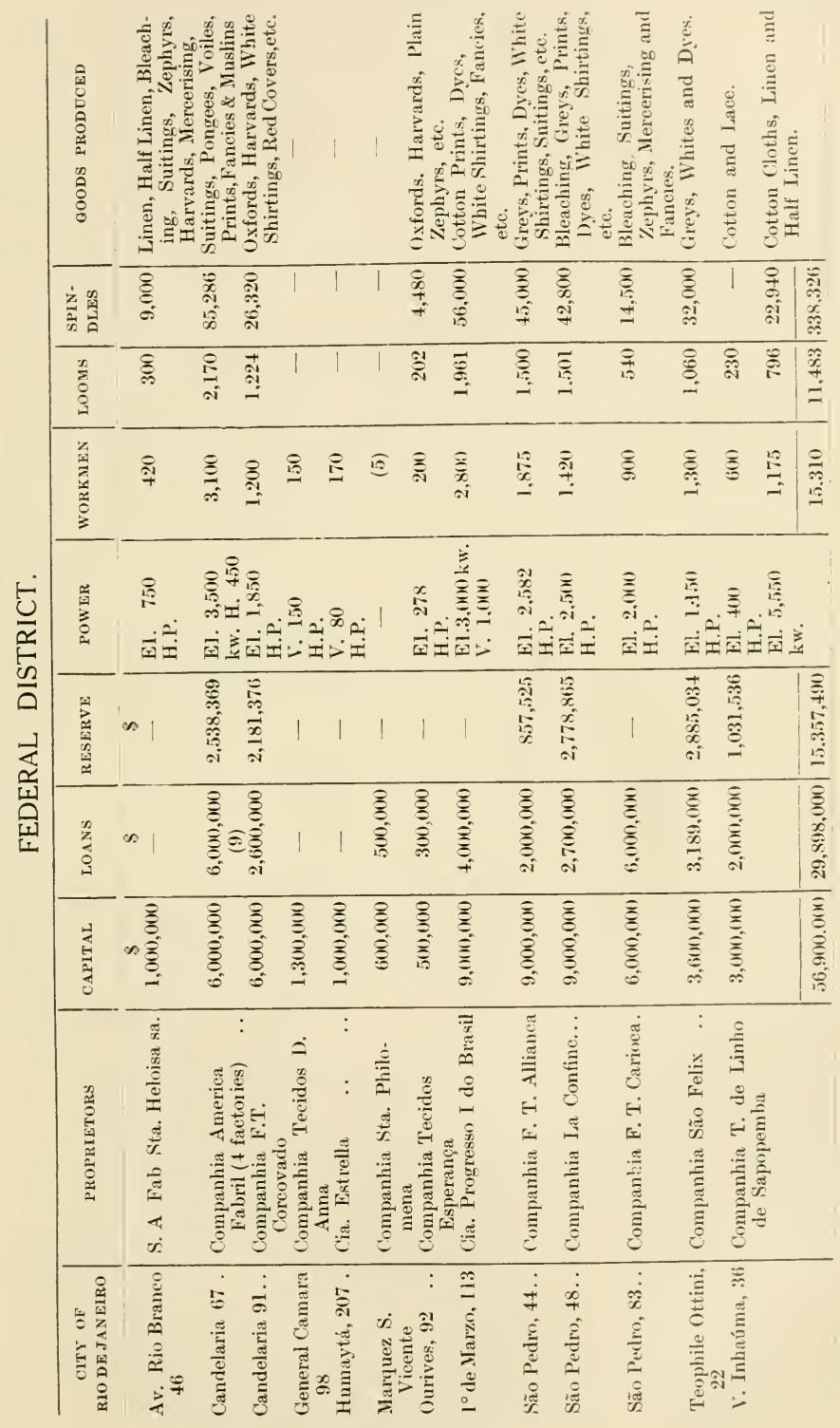




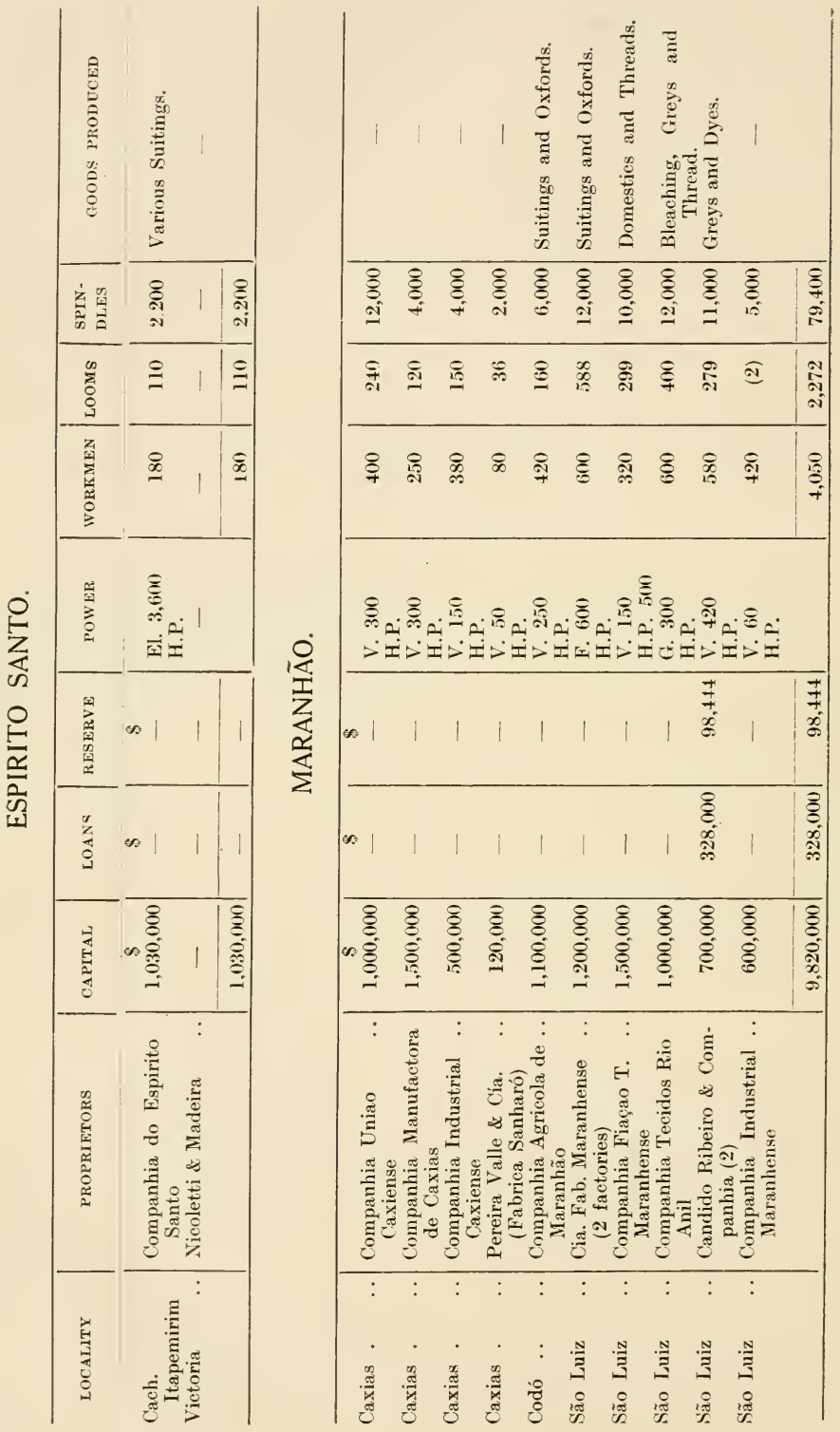




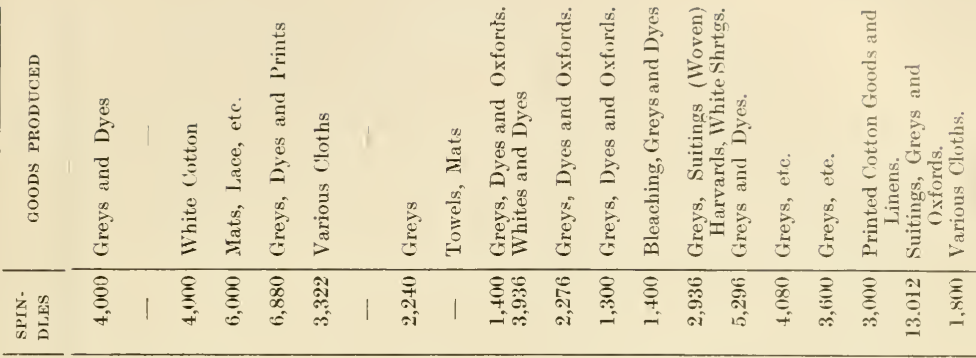

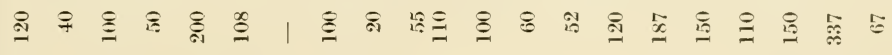

品

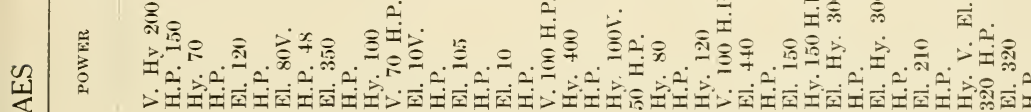

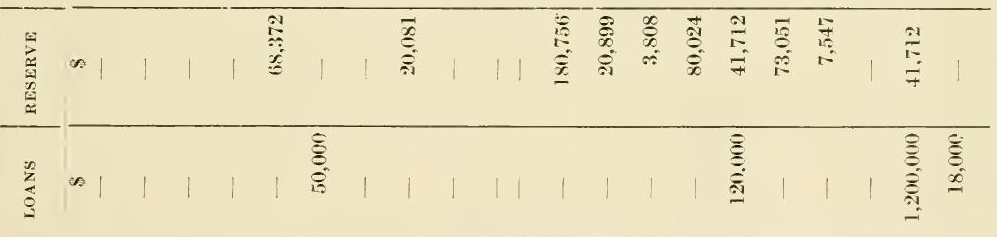

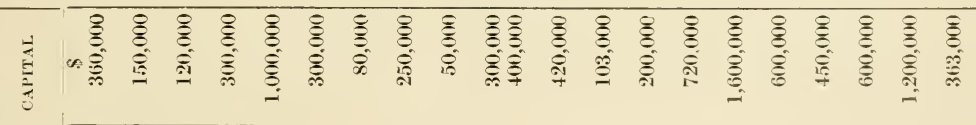

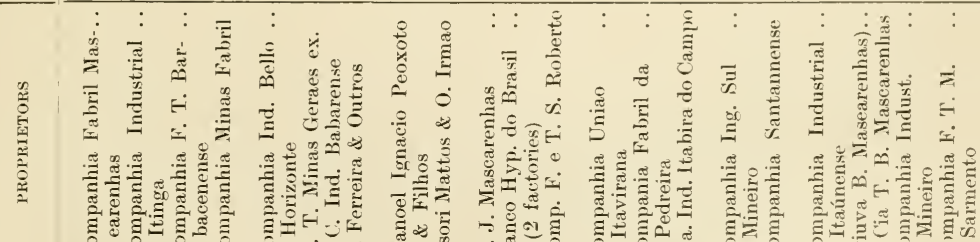

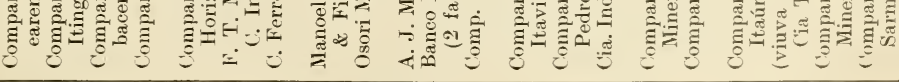

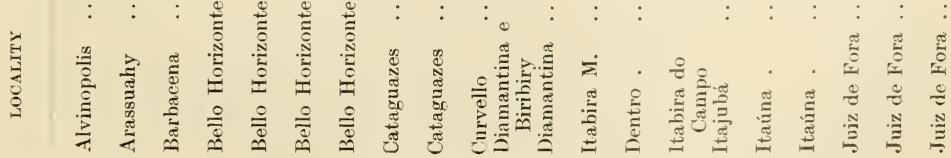




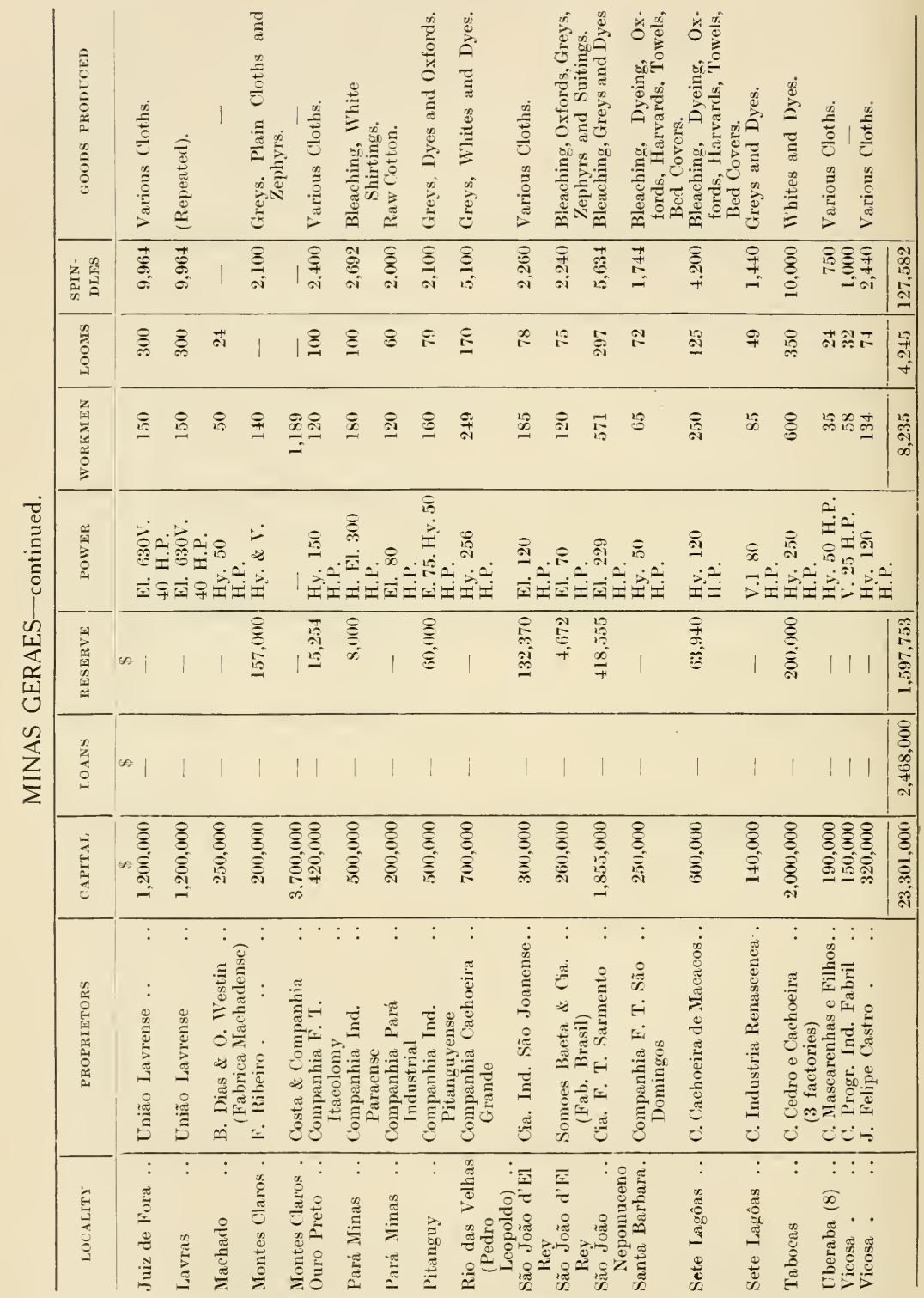




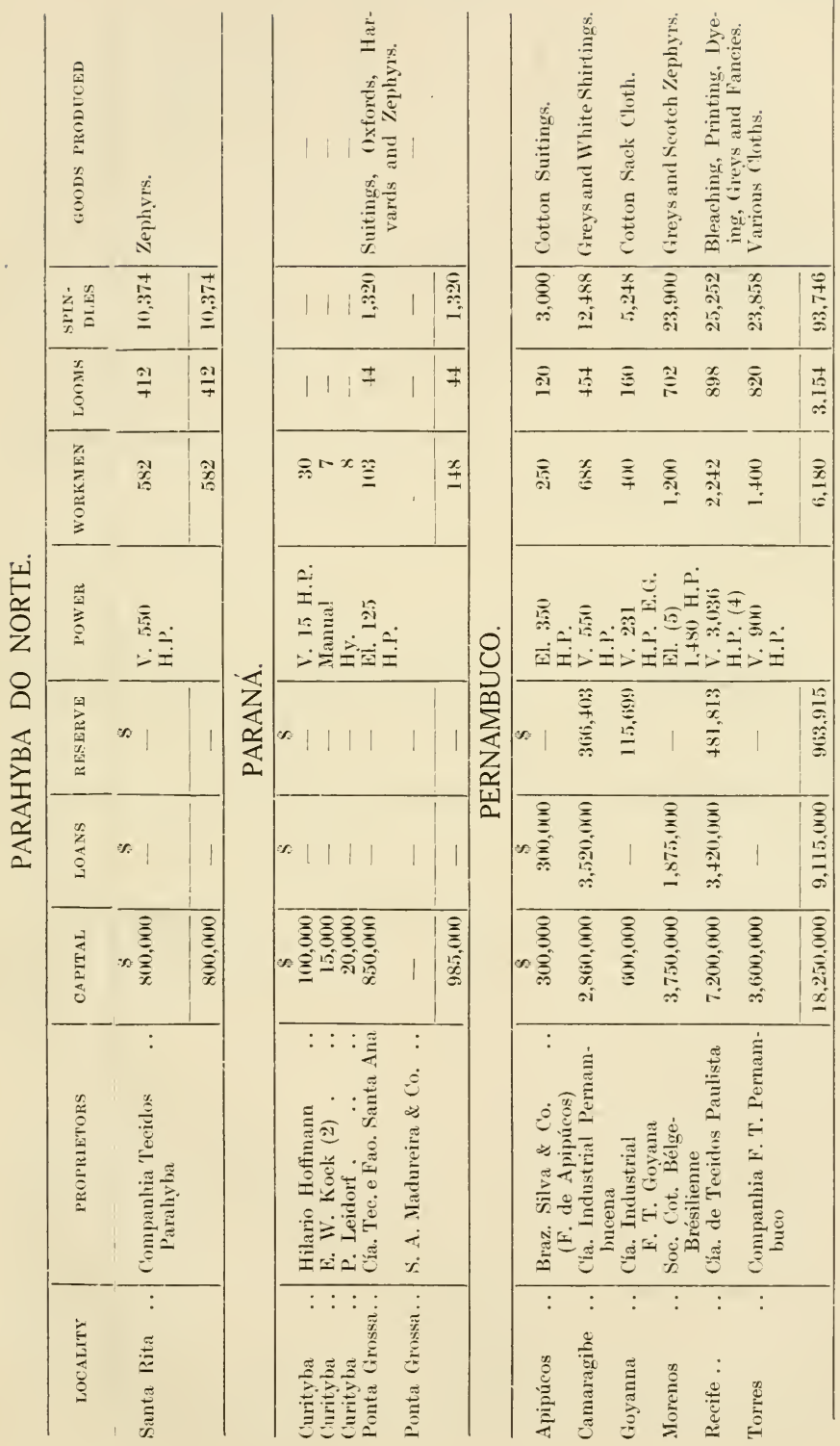




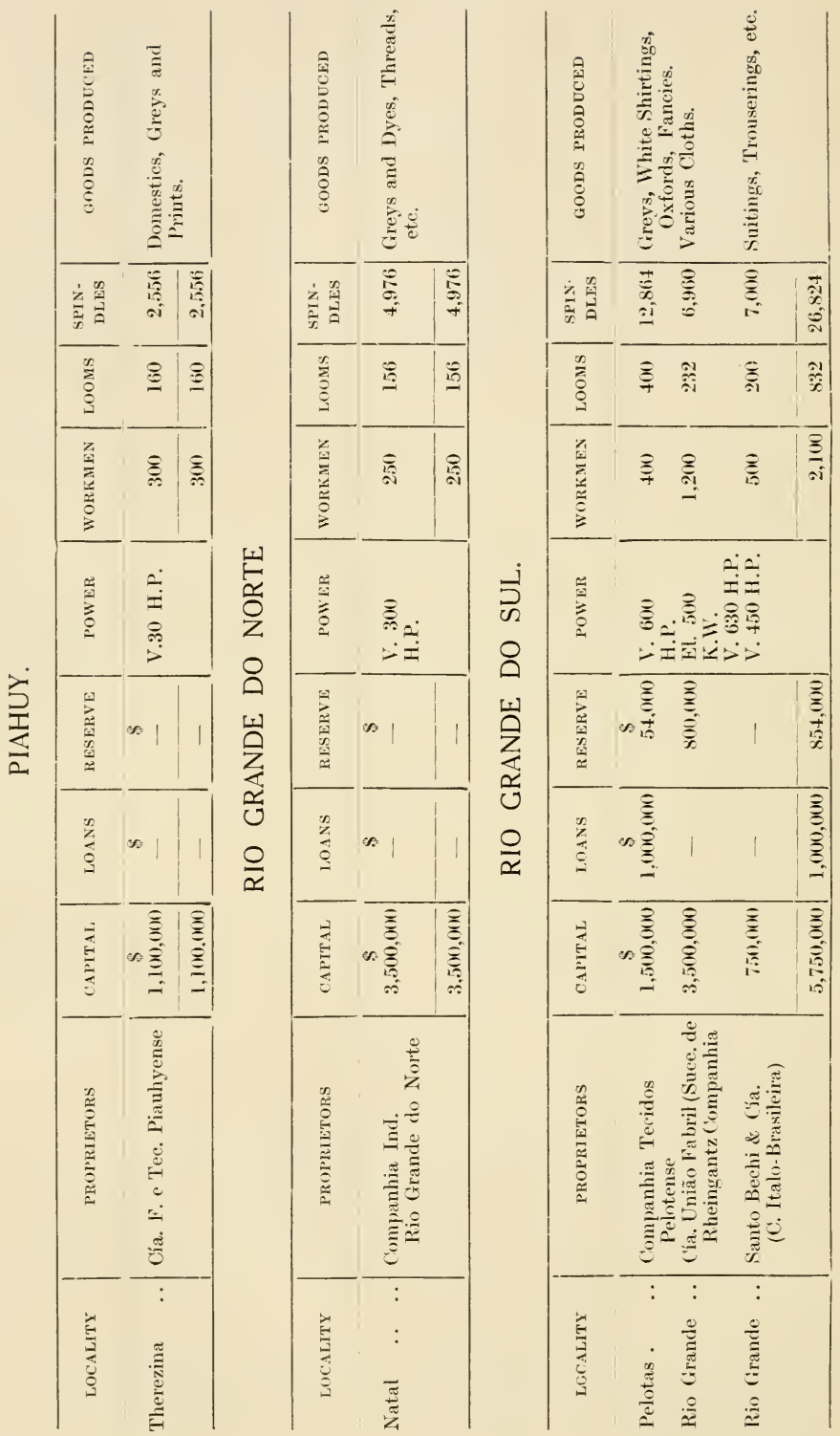




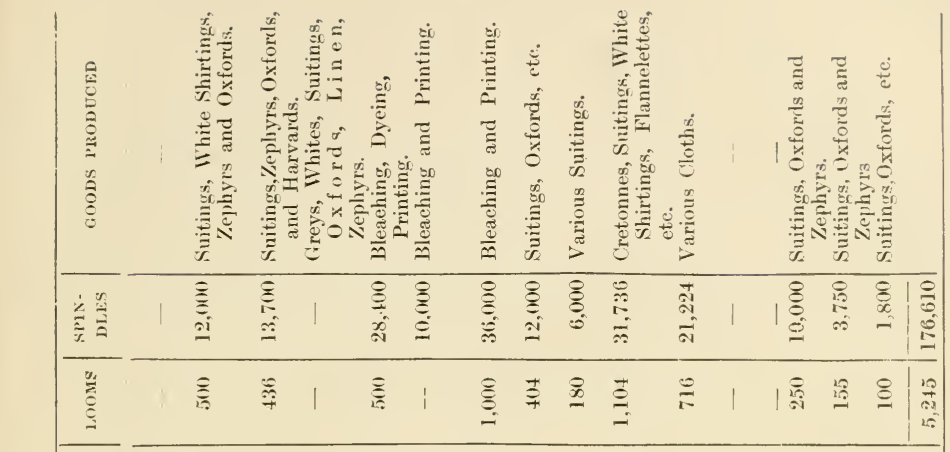

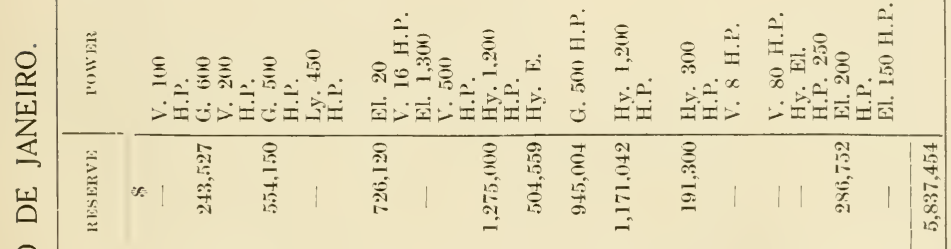

$\frac{0}{\simeq}$

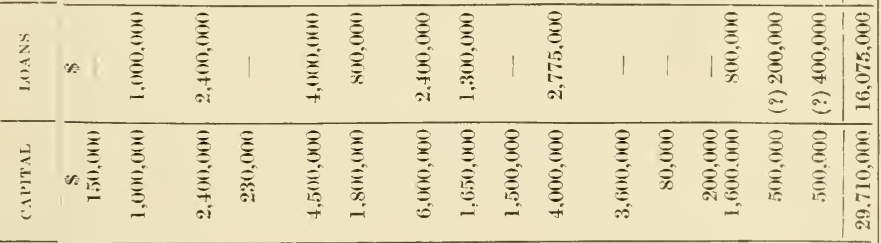

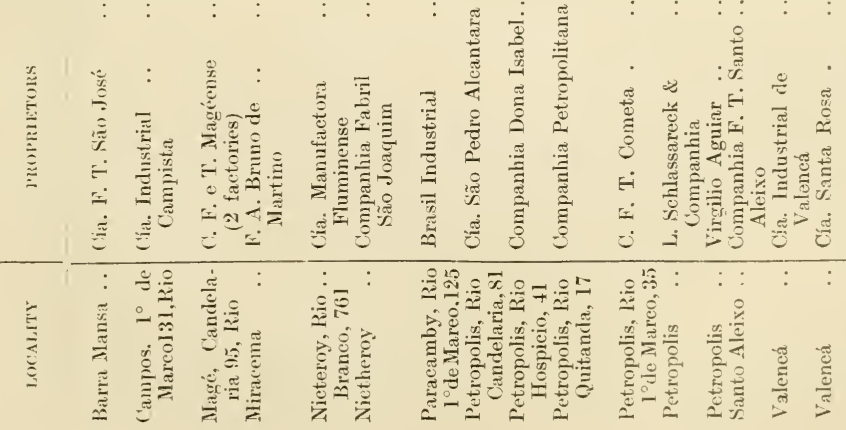




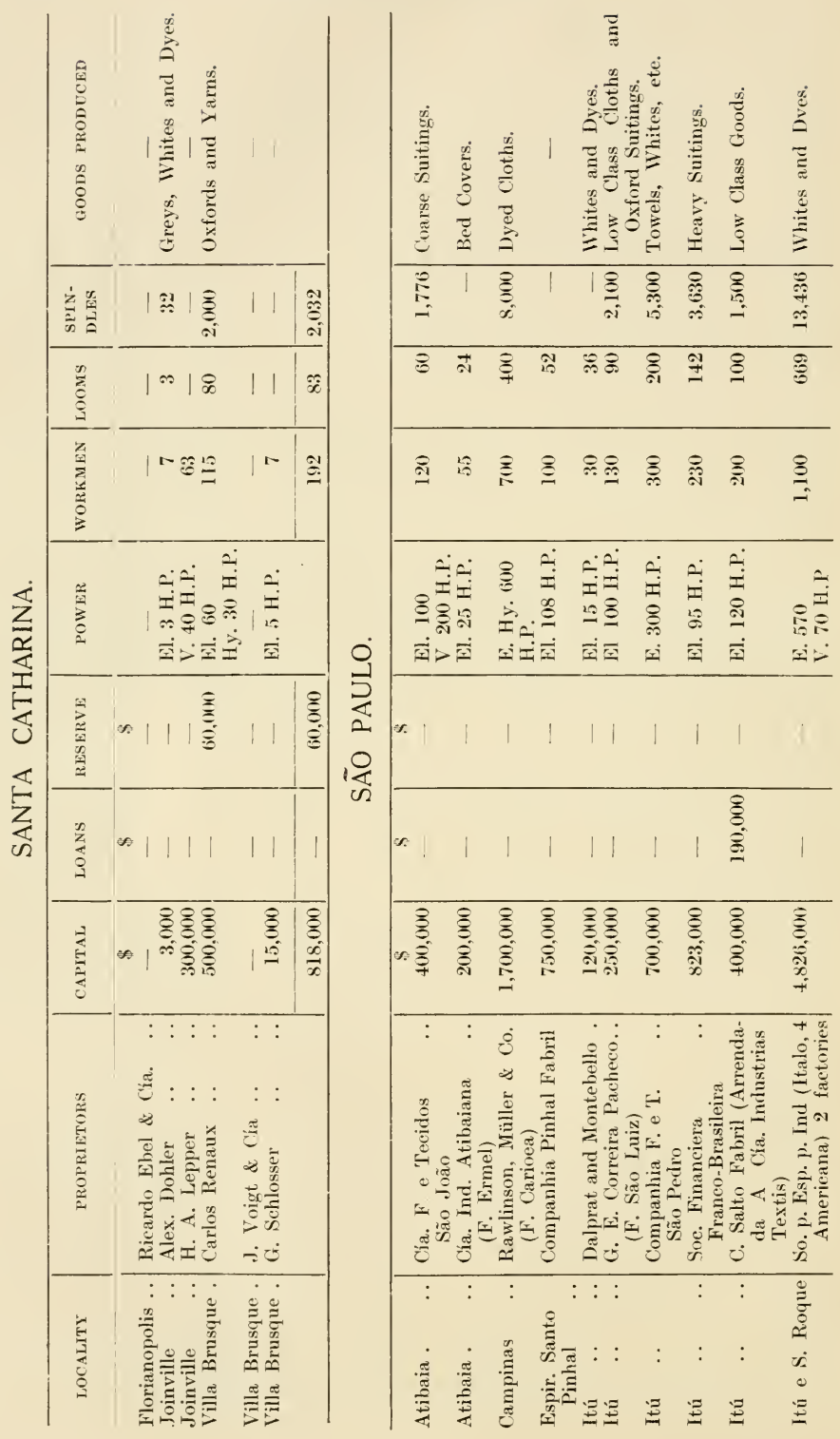




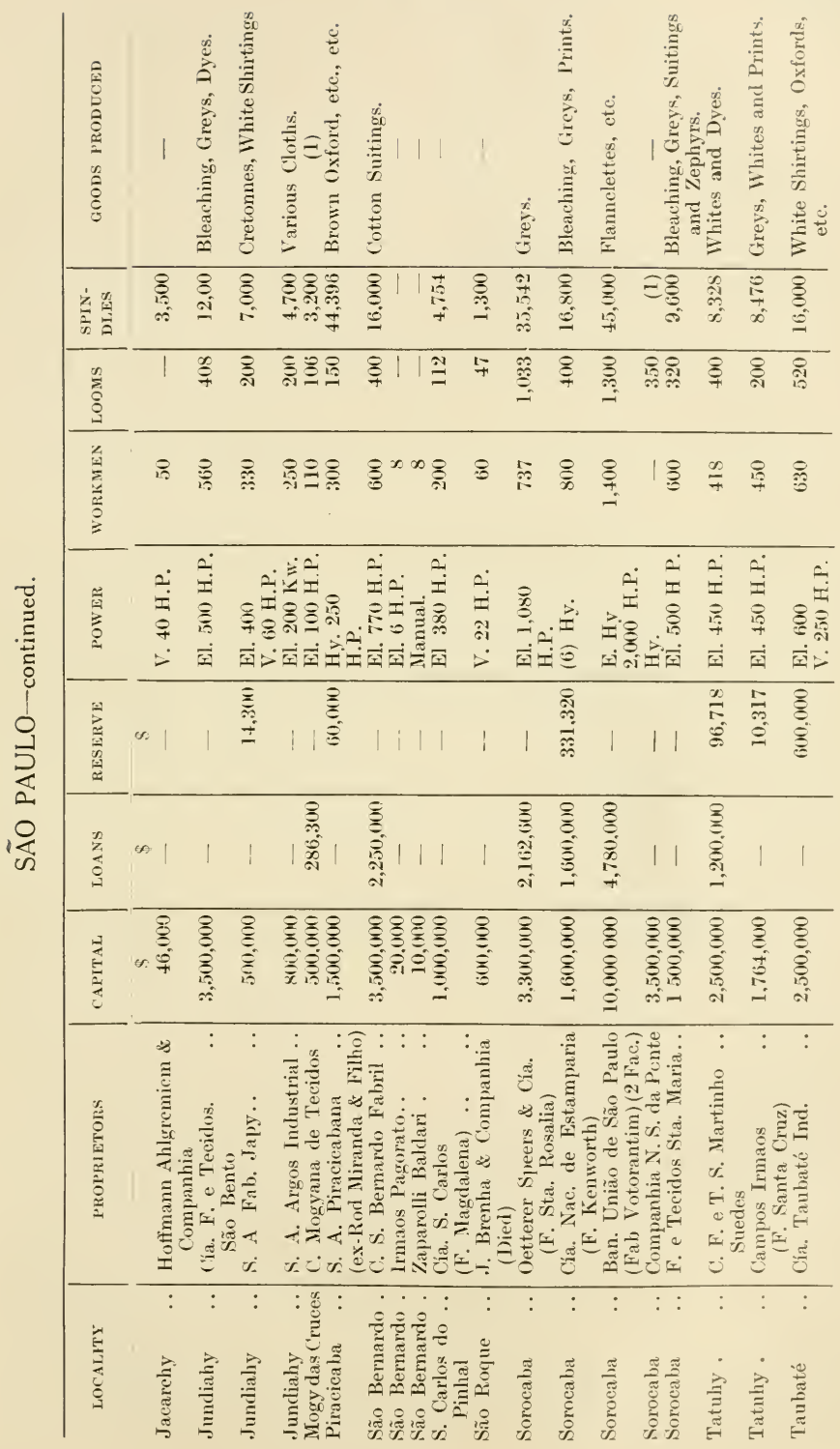




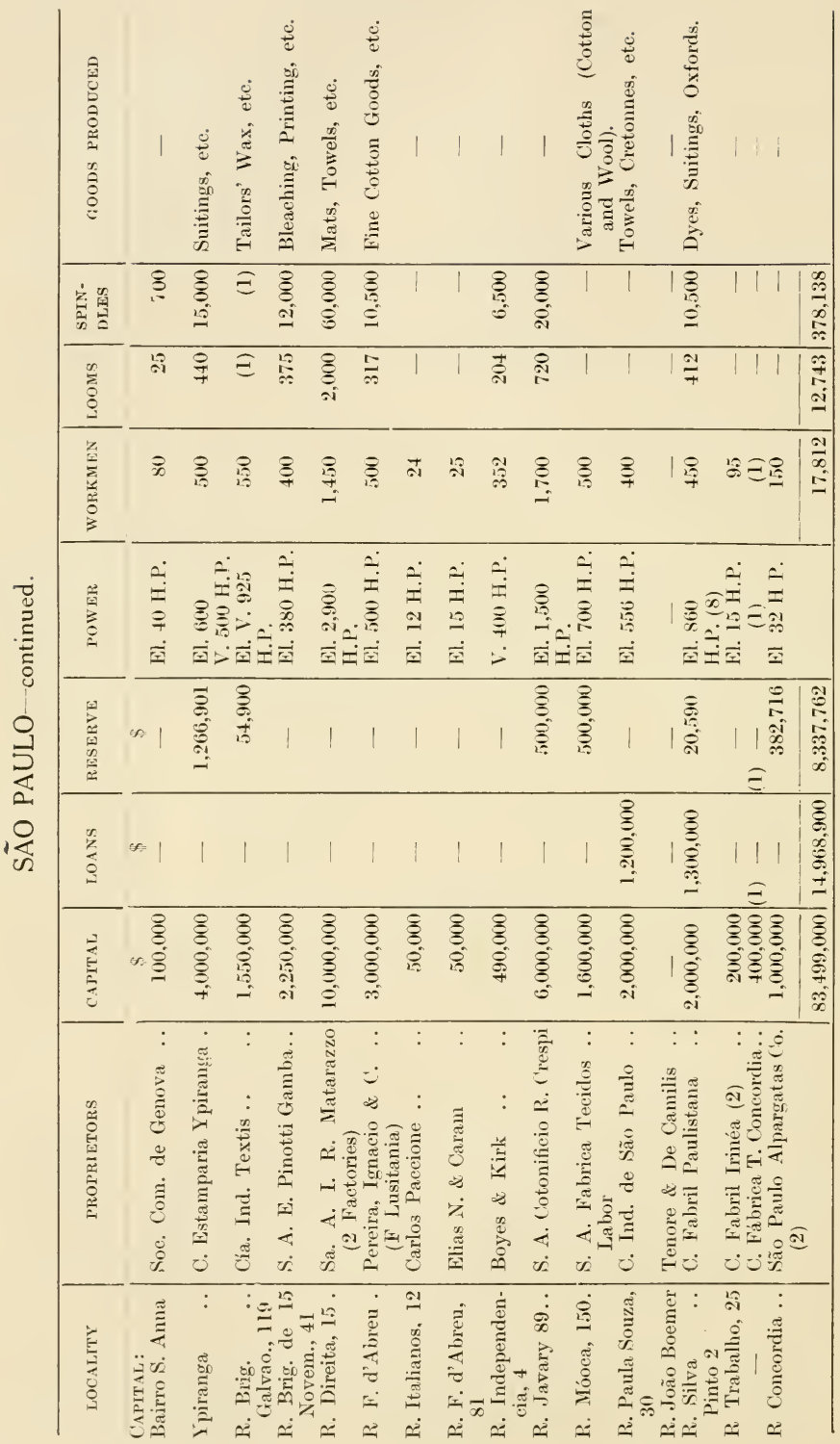




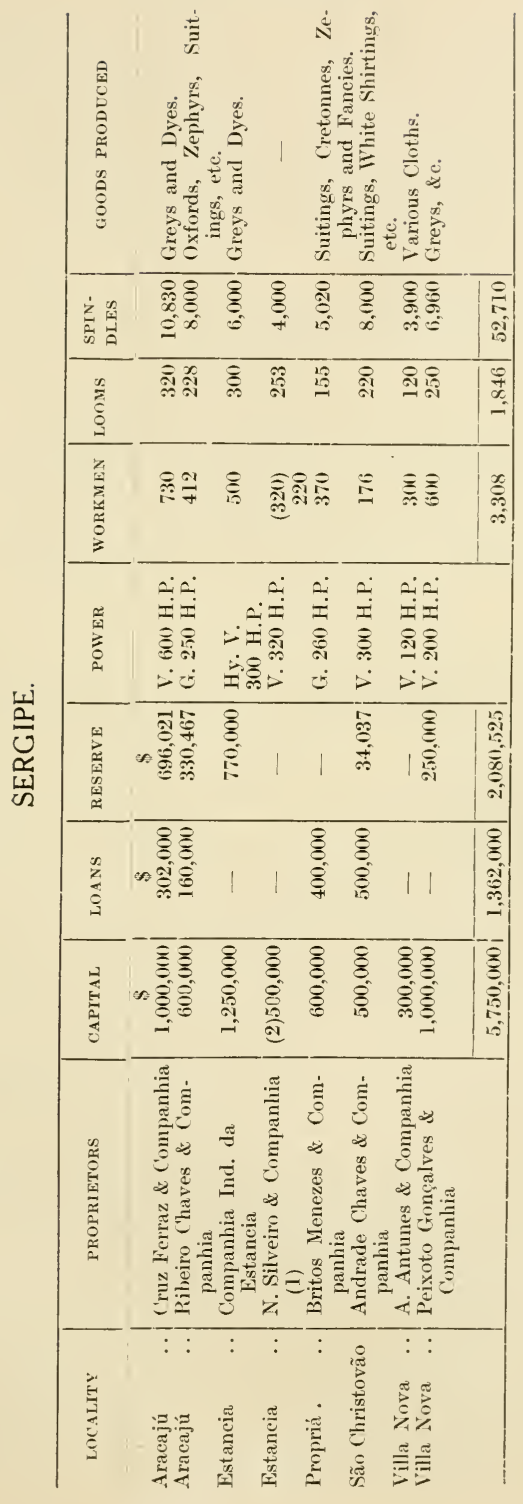




\section{Synopsis of the Impressions of the INTERNATIONAL COTTON MISSION}

on their Journey through some of
the Cotton States of Brazil

*ADDRESS BY MR. ARNO S. PEARSE,

General Secretary of the International Federation of Master Cotton Spinners and Manufacturers' Associations BEFORE 'THE

National Agricultural Society of Brazil, Rio de Janeiro, 16Th August, 1921.

\section{(TRANSLATION OF THE REPORT ISSUED BY THE "JORNAL DO COMHER(IO," DATED 17TH AND 19TI AUGUST,} [921.)

At the Presidential table were seated His Excellency Ildefonso Simões Lopes, Minister of Agriculture, Lyra Castro, Vice-President of the National Agricultural Society, and the Directors Eloy de Souza, Bento de Miranda, Hannibal Porto, Augusto Ramos and Victor Leivas.

There were also present, amongst many others, Messrs. Parreiras Horta. Julio Cesar Lutterbach, Germano Courrege, J. A. da Costa Pinto, Coronel Francisco Schmidt, Cardwell Quenn, Octavio Carneiro, William W. Coelho de Souza, Aleides France, Eugenio Rangel, Gomes Carmo, A. Silva Couto, Nabuco de Gourea, J. Catramby, J. Baptista de Castro, J. Araujo Ferraz, Aristides Caire, Emilo Schenk, Sampaio Ferraz, Fidelis Reis, Consules Oscar Correa e Amynthas de Lima, Arnoldo Murinelly, Alfredo de Andrade, Alberto Jacobina e Carlos Raulino.

His Excellency I. Simões Lopes, who took the chair, stated that the work of this meeting was to listen to the impressions which Mr. Arno S. Pearse, the Chief of the International Cotton Mission, had gathered during his protracted journey through some of the Cotton Districts of Brazil. The Minister of Agriculture then said :-

"In 1919 when the Brazilian Commercial Mission visited England, it received an invitation from the International Federation of Master Cotton Spinners and Manufacturers' Associations to present, at its Committee Meeting in Paris, a report on the possibilities of Cotton Growing in Brazil, and in response Mr. Roberto Cochrane Simonsen 
was sent to deliver a paper, at the conchusion of which he suggested that a delegation should visit our country and this proposal was accepted.

In the following year, at the International Cotton Congress at Zurich, this decision was confirmed and the Mission arrived in April of this year. Thus we had the pleasure of welcoming the Mission composed of Messrs. Arno S. Pearse: General Secretary of the Federation, Max Syz and Fritz Jenny, Swiss Delegates, representing large industrial concerns in that country.

Of the importance of this visit one may form an irlea if one considers the great shortage of raw material which the Cotton Sipinners of the old World have experienced under normal conditions and are likely to realise again within a short time.

As soon as the Mission arrived the Ministry of Agriculture endeavoured, by all means at its disposal, to assist it in its projected tour through the Cotton States in order that the result might be a satisfactory one. We are, therefore, here to listen to the considerations of the Cotton Growing Industry, which the Mission may have to make and we recognise from the outset that, especially from an economic point of view, the existing apparatus in this country may be somewhat defertive."

His Excellency asked Mr. Pearse to address the meeting and he did so in the following words:-

* Your Excellency, Minister of Agriculture. Mr. Presiclent of the National Agricultural Society and Gentlemen: At the outset 1 must appeal to your indulgence, not only because I am a foreigner, who is not as yet thoroughly versed in your language, but also because I come here to give you a few hints after a short journey in the interior of the States of São Paulo, Minas, Bahia, Alagôas, Sergipe, Pernambueo, Parahyba and Rio Grande do Norte.

My words may, however, be of some use because it frequent!y happens that those who are strange to a place notice that which escapes the attention of the residents, due to the fact that they have become too familiar with the obtaining conditions. Furthermore, I must state that I am not here on my own initiative but on the kind invitation of your esteemed President.

Unfortunately, it was impossible to inspect closely all the cotton districts of each of the States visited : to do this would have required many years, but we have certainly examined the conditions of the principal coiton zones of São Paulo, Rio Grande do Norte, Parahyba and Pernambuco, which produce the largest quantity and best quality of Brazilian cotton. I may even be so bold as to state that nobody has ever visited so many cotton fields in these different States as this Mission has done. Our object after inspecting the fields was to gather together the cultivators with a view to explaining to them the shortcomings of their present method of cultivation, so that our tour should not only be instructive to ourselves but also be of some educational value to those who till the soil and look after the handling of the raw material.

The area suitable for cotton cultivation in your country is larger than that of the U.S.A., and the conditions of climate and soil obtaining 
in Brazil are probably more favourable to cotton cultivation than in any other part of the world, yet Brazil does not produce, at the best, more than 700,000 bales $(500 \mathrm{lb}$. each) of cotton against the $12 / 16,000,000$ bales in the U.S.A.

In the first instance, there is a shortage of labour but with impending immigration from Europe, which promises to be large during the next few years, this disadvantage will be somewhat reduced.

In São Paulo and the North-east of Brazil the yield per acre is larger than in any other country of the world and the Mocó fibre of the Serido (Rio Grande do Norte) is undoubtedly equal to that which Egypt produces.

Allow me to eall your attention to these extraordinary possibilities which your rich country possesses and I, for my part, will undertake to bring to the notice of the cotton spinners in Europe the qualities of Brazilian cotton, which to a great extent are to the present day practically unknown and I trust you will have an opportunity of seeing, after the publication of my Report, that many spinners will make their first trials with your cotton.

Our visit has attraeted general attention throughout the country, especially where cotton is grown: al! the newspapers have dealt with the Mission and have constantly reported its progress and I take this opportunity of expressing our cordial thanks for the service which the Brazilian Press has rendered in this direction. My thanks are also due to the merchants and traders, planters and small farmers-in fact, to all the inhabitants of the cotton zones visited by us, as everybody with whom we came in contact manifested the keenest interest in our work, and I trust that one of the results will be a better understanding between the consumer and producer of cotton.

Besides the shortage of labour, which is especially noticeable in the North, there are various factors which have prevented Brazil from occupying that place which nature destined for her as a world supplier of Cotton. You have no cause whatever to complain of any shortcomings of nature, but you must recognise the utter laxity displayed by those whose duty it is to grow and handle the Cotton. Once you have overcome your own personal shortcomings there is no reason why Brazil should not become one of the largest sources of supply of Cotton. With the exception of Coffee it may be said that there is no product of Brazil which is sold in the markets of the world at the same high level as the products from other countries, the reason of it being the absence of classification by grower and merchant.

SeEd FArms.- There is, without exception, a complete absence of uniformity of fibre amongst Brazilan Cottons. After having visited more than 1,000 cotton fields I can state that we have not found ten plantations where any effort has been made to separate the seed and 3 to 5 varieties are grown together everywhere in one and the same field $w^{\text {th }}$ the result that a picking gives short and long fibres, coarse and silky ones. The buyer must make his price for the shortest fibre and for this reason the farmer does not often receive a lucrative price. We saw fibres of $20 \mathrm{~mm}$. close to a plant producing $40 \mathrm{~mm}$. and the price which will he paid for that cotton will certainly be based on the $20 \mathrm{~mm}$. cotton, whilst if the long staple cotton had been planted 
separately the selling price would have been twice as high. It is very easy in your country to separate seeds of the various types because they are easily recognised, so much so that even a child could soon undertake satisfactorily this kind of work. The spinners of Europe continually complain that they cannot receive from Brazil uniform qualities. They buy one lot of cotton and when they order the "repeat" they find a great difference in first and second deliveries. This lack of uniformity can only be remedied through the distribution of good seed and of one type only. In order to achieve this it is absolutely necessary to establish in each cotton zone a seed farm for the production of the seed which best suits its conditions. I consider that such establishments should be owned by the Federal Governments, or if they belong to private parties, they must be subjected to strict supervision by Government experts.

The work of producing standard varieties of seed appertains to the scientific branch of agriculture and for this reason it is only in rare cases that the ordinary planter can undertake this work successfully. Though this may only be a simple process once the machinery has been set in motion, yet it requires patience and continuity of action.

Brazil's first requirement is plant selection, i.e., the seed must be separated according to its external characteristics; when the first capsules appear those plants must be singled out which have a large number of bolls and which are bearing right from the bottom branches; once the bolls open it will become necessary to inspect each one of the selected trees and to ascertain the length, strength, colour, etc., of the fibre. Only the seed emanating from bolls which have thus been selected must be used for planting purposes in the next season and thus you will be sure that the new plants will, to a great extent, reproduce the good qualities selected in the previous year. In this manner it will be possible to increase in a few years the length of the fibre by 2 to $4 \mathrm{~mm}$. as has been demonstrater in other countries and also in Brazil on the plantation Salto Grande, near Villa Americana, in the State of São Paulo. The strength of the fibre and other good poinis can in this way be improved.

The seed farms require to be of fair size because you will have to produce on them sufficient seed to supply the requirements of all growers of cotton in each district and being of considerable area it will be easy to manage them in such a way that some financial benefit is obtained. especially if mechanical means of cultivation are introduced. Seeing that this work of selection must be undertaken with great care, it will be necessary for the technical expert of the Cotton Department of the Federal Government of each State to undertake it personally, beeause it will depend upon his work whether the seed farm proves a success or a failure. Such an official must reside on the plantation and not in a town. He will also have to superintend the staff and his duties will further consist in travelling through the country, explaining to the planters, small farmers, prefects and other interested parties, the best way of cultivating cotton. Care must be taken that such district grows only one kind of cotton in order that hybridization and the mixing of seeds at the gin are made impossible. The seed farms will also serve as model plantations where one may be able to ascertain, not only the method of cultivation, but also the exact cost of growing. 
The fields will serve as a demonstration for the rational method of cultivation with ploughs, etc., rotation of crops. I am not advising the Government to undertake the establishment of these farms in the expectation that public funds will be required annually to subsidise them; on the contrary, the farms which I propose, ought to show every year a handsome profit and the manager, who is unable to show after two years' working that a profit can be made, must be replaced. Such farms should be establisher in each State-perhaps Alagôas and Sergipe might require only one between them.

Allow me to insist that these seed farms constitute the key to the cotton problem of Brazil; if you delay, or if you do not create these farms you might as well give up all idea of ever achieving anything in the way of improvement, for Brazilian cotton will never be ahle to compete in the world's markets with cotton from other countries and within a comparatively short time your cottons will depreciate so much that the cotton mills of Brazil will be obliged to import from the U.S.A. a large amount of their raw material. Cotton is a plant which lends itself easily to hybridization. It is exactly the same as with eattle. In the raising of stock every farmer recognises the importance of pure blood-with plants it is the same, especially with cotton. The mixing of the seed in the ginning factories and the crossing in the field caused by inseets or by wind have reduced the quality and probably the quantity of your cotton and this retrogression is bound to continue unless you establish the seed farms about which I have spoken at length. I may cite the case of India. Some three centuries ago the natives there produced on their hand-looms sueh delicate textures as we camnot weave to-day with the most up-to-date machinery. There is evidence to show that these diaphanous cloths were procluced from cotton grown in India. To-day there is not to be found in India a fibre of greater length than of $28 \mathrm{~mm}$., and by far the largest portion of the Indian crop consists of half that length. The explanation of this reduction in the length and fineness of fibre is clue to the fact that the seeds have been mixed during these many years and the pollen of one variety crossed with another, so that India which at one time produced the longest fibre in the world is known to-day as the supplier of the shortest fibre. During the last 20 years the Government of India has engaged competent botanists to separate the different types which exist and there is now noticeable an improvement in the fibre. The case of Brazil is identical with India as was proved to us in the Serido where the best cultivators told us that the truest strain of "Mocó" no longer existed and a Liverpool cotton elasser who has been in Brazil for the last eight vears assured me that during this period he had noticed a falling off in the Moco quality. All your cottons show signs of hybridization, and it is high time vou stopped this retrogression. I ain not orerstating the case when I tell you that the mills of Brazil will be foreed to import cotton from elsewhere if you do not adopt such means as I have pointed out. You have the means - without annual outlay of money to produce large quantities of cotton of a uniform type and thus increase your exports of cotton, which will naturally tend to consoliclate the financial position of Brazil; but if you show apathy, you will be drifting to that state when your largest inclustry will be obliged to send out of the country considerable sums of money for the purchase of its raw 
material, which a little foresight and organisation would have raised in your own country.

Picking.---A considerable loss to the grower and to the country at large results from the careless picking of the cotton crop. In the course of my journey I had the opportunity of verifying by means of an actual transaction between Parahyba and Liverpool, the differences of prices obtained for one and the same quality of cotton, some of which was clean, some dirty, and some of medium grade. The respective prices

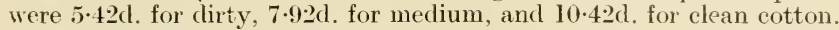
I was also told by Boxwells that out of 800 odd bags in one lot there were only 28 bags which they could classify as clean. The price for the latter would be $20 \%$ above the average.

It is very easy to pick cotton clean, and comparatively little more trouble is nccessary to olstain the above price difference. Each picker should have two sacks-one for clean cotton and the other for dirty cotton, dead fibres, etc. Many farmers think that dead fibres and extraneous substances increase the weight of cotton and consequently the profit. This is a capital error, as I have shown in the above actual transaction. It is really a pity to see how your people reduce the value of the fibre through carelessness in the picking.

In Bahia and generally in the North trade has established a difference in price of $50 \%$ between clean and dirty cotton, and in Parahyba it is almost impossible to find a buyer of dirty cotton at any price. Thus the farmers will learn to pick their cotton clean at the expense of a considerable reduction in the price. In São Paulo and Minas the difference between clean and dirty cotton is not sufficiently high. which undoubtedly accounts for the dirty condition in which the cotton is picked.

Seridó cotton comes into competition with Egyptian cotton. I saw how in Egypt children and women whilst picking cotton took into their mouths those parts containing leaves and dry substances and by suction separated the foreign matter from the lint. This shows how much care is bestowed upon clean picking in Egypt.

On my journey through the North I noticed that women picked better than men and they understand better what constitutes the quality of cotton. This is probably due to their occupation of spinning by hand, a process which is still carried on in many parts of the Interior.

Cotton must not be picked whilst the dew is still on it. Cotton must be dry, as damp cotton cannot be ginned satisfactorily. It is likewise prejuclicial to leave the bolls too long open before picking as two or three days of hot sun eause the fibre to lose strength. Should it rain during the picking season, it is imperative to gather the cotton as soon as it becomes dry, otherwise the exposure to the sun after the wet burns the fibre.

MARKETs. - The market buildings existing in almost all the municipalities might be used for the sale and purchase of cotton. In this way the farmers would receive a better price. The bales would be weighed on official scales and when one farmer sees that his neighbour receives due remuneration for the greater care in the picking, seed selection, etc., he will undoubtedly emulate his example. These markets would receive the current prices from the neighbouring places 
and thus the seller would not be at the mercy of the sometimes unscrupulous buyer, who only too often takes advantage of the ignorance of the small farmer. Each municipality would have to establish a set of rules, one of which would have to be that each bag must bear the correct weight and the name of the grower; provision would also have to be made that the party who sells damp cotton or otherwise fraudulently adulterates cotton is punished.

In Pernambuco we came across a typical case, where a small farmer sold his cotton at the rate of two milreis $(1 / 2)$ per 20 kilos $(44 \mathrm{lb}$.) seed cotton. The buyer was a rich man in the neighbouring town and must have known that the ruling price was five milreis. Such cases could not occur if the cotton were sold in the public market place.

The establishment of Co-operative Societies amongst the farmers is also advisable. They can be used in many ways, especially for the facilitation of credit, avoiding the usurious rates of interest, as is the case at present. In India such societies are also made use of for the distribution of seed, for the purchase of agricultural machinery, etc. It appears to me that the Prefects (Mayors) of the cotton districts might undertake the formation of such societies, which have proved of great benefit throughout India.

Ginning.- One of the greatest evils to which Brazilian cotton is subjected is ginning, which-in most cases-is carried out in a most unsatisfactory manner.

You all know that in this country only saw cotton gins are used. These machines are perfectly right when dealing with short staple cotton, i.e., with fibres up to, say, $28 \mathrm{~mm}$., but when nature has given you staple cotton of good length it is a gross error to employ saw gins which cut and reduce the length from 5 to $7 \mathrm{~mm}$, as I have proved to be the case. These five $\mathrm{mm}$. cause a great difference in price: they may be the means of making a handsome profit instead of a loss.

In the world's markets there is a shortage of long staple cotton and for this reason its price is relatively higher than would otherwise be the case. Long staple cotton must be ginned by a roller gin. such as is in use everywhere in Egvpt, India, and even in the Sea Island and Arizona districts of the U.S.A.

I have made a good deal of propaganda in the North of Brazil in favour of this gin : it could also be used to advantage in many parts of São Paulo. These machines are' called " roller" gins and are constructed by various machinists in England and Germany. The best known make is "MacCarthy:" of Platt Brothers \& Co. Ltd., Oldham. I am not here to advertise this or that machine. A Rio newspaper stated that I was representing an English machinist: this is untrue and I may state here again that I have no personal profit from the sale of any machines. I brought with me some catalogues of English and German machines, which I handed immediately to the Supcrintendent of the Cotton Department.

In the North there have been established recently a few modern ginning factories amongst which I mention those of Trajano de Medeiros \& Co., Sociedade Algodoeira do Nordeste Brasileiro, Companhia de Beneficiamento \& Prensagem do Algodão in Campina Grande. These new factories work well and their owners have undertaken to 
supply first-class seed to the farmers for planting purposes, but by far the greater part of the gins in the country, especially in Minas, are saw gins of a very inferior type. It is an exception if the saws are ever sharpened or overhauled. We found one saw gin which had been working for 16 years without having the blades sharpened. Any number of gins harl been working four or five years without any attention to the saws. Naturally, saws in this eondition must eut the fibre. This work of sharpening the saws is so important that the Cotton Department should hand to one of their own travelling offieials an apparatus for this purpose. When the saws are sharpened it is generally the case that the whole blade is filed whilst on!y two-thirds should be attended to and the bottom corner should be left blunt. Another great drawback resulting from the gins is that the machines are worked too fast: whenever knots are visible in the ginned cotton you may be certain that the machine was running too quickly. A leather cover of two or three layers over the pulley on the gin will soon remedy this evil.

We have seen that in some of the modern ginning factories mechanical openers such as the Creighton Opener are being used : this is a machine that really belongs to the spinning mill. Cotton treated by this machine, if run fast, is liable to lose the "bloom " of raw cotton, which is so much appreciated by the spinner. An apparatus which does not injure the fibre and does similar work to the opener is a simple contrivance consisting of a hexagonal sieve with small meshes, about 8 by $10 \mathrm{~mm}$. wire-netting gauge. This sieve is in a slanting position and rotates slowly ; the cotton enters at its upper portion and is thrown with little force from one side to the other and gradually it passes out at the lower end of the sieve in order to be taken to the ginning machine. This apparatus extracts a great deal of dust and dirt and does not rob the fibre of the bloom as do almost all the openers. It must also be taken into consideration that such eontrivance is easily made at any workshop and costs very little money. In Alagôas and Sergipe there is hardly a ginning factory without snch a sieve.

The major portion of the ginning machines in use in Brazil reduce enormously the value of the fibre. The Federal Government reeognises the necessity which exists for the employment of roller gins and allows their importation free of duty. They are constructed on the same principle as the old-fashioned hand-gins used by the natives in the Interior.

MIxtre of SEEDs.-A still greater evil results from the sale of mixed seed by the owners of ginning factories. It is a general custom in Brazil when a farmer requires seed for sowing purposes to buy the necessary quantity at any gin in his neighbourhood, regardless of the number of varieties of seed available. The small farmer plants any seed he is given (and it generally consists of at least five varieties) : the result is, of course, that in due time his field presents a diversified aspect of all these varieties. The evil produced in this manner through the sale of seed by the ginning factories means that all the good done by the Cotton Department is being undone. It is indeed regrettable that on the one hand the Government expends a great amount of labour for the improvement of cotton cultivation and on the other 
hand it allows this work to become nugatory through the action of the ginning factories distributing mixed seeds.

Just in the same way as it is the duty of every Government to combat epidemics which threaten human life, and in this instance Brazil occupies one of the first places in the world through the initiative of its famous hygienist-Dr. Oswaldo Cruz - thus, also it behoves the Government to protect the economic life of its people, and certainly cotton constitutes for Brazil an essential part of its economic life.

Various states, such as Maranhão, Parahyba and Sergipe, have organised on special lines Cotton Legislation, based on a Federal Decree of the same kind which should be followed by other cotton producing states of Brazil. The Government of Rio Grande do Norte has also passed legislation to prevent frauds as regards the exportation of cotton.

In the State of Pernambuco we saw in a ginning factory a certain amount of linters being mixed openly with each bale and the proprietor innocently explained that this practice brought him in 30 Contos every year (1 Conto-about $£ 38$ to-day). Evidently this man did not know that he was committing a fraud, but nevertheless it is necessary to put a stop to such practices.

Virieties of Brazilian Cotton.--On our journey we found several indigenous kinds of Brazilian cotton varieties, which, I feel certain, will have a great future if the recommendations made with regard to seed farms and supervision of the sale of seed by ginners are adopted.

Amongst these varieties I must mention in the first instance Riqueza, which is also known under the following names: Verdão. Verde, Azul, Rompe-Letras, etc. This cotton has a large green seed. which is easily distinguished. We first saw it along the São Francisco river and we could trace it right up to the northem coast (Mossoró). In most places when the seed was pure its fibre distinguished itself by its special strength and its silky appearance-indeed I do not know of a more silky fibre and its length was occasionally as much as $3 \tilde{J}$ $\mathrm{mm}$. From what we could learn from the planters, it is a good yielder and resists insect plagues well, though on this point opinions werc somewhat divided. Speaking generally, it seems to me that Riqueza might be cultivated in a vast territory extending from Chique-Chique on the São Francisco to the northern coast. Of course, there will be districts where the soil and climate are not suitable and other varieties will have to be planted. One of these zones is in the Serido, which may be defined as that part of the country in which are situated the following six municipalities: Caicó, Jardim do Seridó, Acary, Flores, Curraes Novos and Serra Negra, all situated in the State of Rio Grande do Norte, where the only variety to be cultivated should be Mocu.

Your Government would fail in its duty if it were not to establish here a seed farm especially destined for the production of pure Mocú seed. The cultivators of the Serido, which district we inspected very closely, travelling for the most part on horseback, complain of the difficulty of procuring pure seed. The Federal Government have already bought, in connection with the construction of a dam, most suitable land for such a farm in the valley of São José, near Cruzêta. 
1 plead with the Minister of Agriculture not to let this excellent opportunity pass for the establishment there of a Moeo seed farm. The Serido is a cotton zone in which you find united all possibilities for favourable cultivation of very long fibre. According to the information available, it seems that the yield per aere in the Serido is about $25^{\circ}$ larger than in Egypt, and it must be borne in mind that in that country intensive cultivation with irrigation is resorted to, whilst in the Serido this high yield is obtained with comparatively little or hardly any work: in the Serido the cotton trees last 10 to 15 vears, whilst in Egypt they are planted every year afresh. In the one, hardly any cleaning in the field takes place, whilst in the other weeding is constantly necessary.

In the Serido some farmers are already recognising the value of seed selection, and the fibre obtained in this way by them compares favourably with Sakellaridis-the best cotton of Egypt. I have found some bolls of Mocó, the fibre of which measured $50 \mathrm{~mm}$. and certainly $45 \mathrm{~mm}$. is quite a common length. This shows that climate and soil are able to produce the very best cotton. A few Brazilian cotton mills spin $80^{\circ}$ s and even $125^{\circ}$ 's with this cotton.

Another variety which must not be lost sight of is "Rim de Boi," known at times as "Inteiro," "Creolo" and "Maranhão." The seed of this variety is peculiar in so far as 7 to 8 seeds adhere together in the shape of a kilney (the Portuguese name of which is " Rim,") or it may also be compared with the shape of the rattle of the rattlesnake. The fibre of this variety is exeellent, strong and of a good colour. The natives prefer this cotton to any other for spinning on their hand spinning wheels. The ginning outturn of this variety, however, is small as the seed is rather heavy and the adherent facets of the seeds cannot bear any cotton. "Pim de Boi " might he cultivated with good success along the São Francisco river.

The annual herbaceous kind-American " Tpland" - is well suited for São Paulo, but in the other States it should not be eultivated, except where it has been found that "Riqueza" does not do well. " Epland" has the advantage of producing "bolls" within a short time. for instance, in Alagôas or Sergipe this type requires only three months from the planting to the pieking and I an told that in Maranhão only $1 \frac{1}{2}$ months are necessary. The fibre of this variety is short and therefore it should not be planted where there is any chance of a longer fibre being grown with success. It would indeed be a real disaster if this herbaceous cotton were planted in the Serido or neighlsouring district as has indeed been done in Pombal and Lagôa do Monteiro where the farmers have planted one row of Mocó and then one of herbaceous; this has, of course, resulted in a depreciation of both kinds. Happily, we were able to convene a meeting of the planters of Pombal and point out to them the error which they had committed. The quality of soil and climate have, of course, a great deal of influence on the different kinds of cotton. Mocó resists the great droughts. and at the same time withstands the floods, whilst most other varieties can only exist under the conditions of sufficient moisture. The cotton department of the Government, which is in good hands, under the management of my distinguished friend, IIr. William Wilson Coelho de Souza, will have to decide the varieties which are best suited to the 
different zones. However, this principle must be strictly adhered to-." to plant only one variety in each district and this must be pure."

In the course of our journey we were able to learn that the pink boll worm has not done great damage this year and that some planters have overcome the ravages of this plague by spreading the seed out in the sun during a few hours prior to planting. In order to preserve the heat, it is recommended to mix sand and charcoal with the seed. In the North a new insect has appeared, "Nysius erlcoe, Schill; of the family Lygoeldae, sub-order Heteroptero-order Hemiptera." It is commoniy called "Perseveio" (in Portuguese "bug ") owing to the strong smell emanating from it, which is very much like that of the common bug. Many farmers hold the opinion that this new insect is a natural enemy to the pink boll worm, but as it is not a carnivorous insect, this can hardly be the case. So far as is known, little clamage has been done. The best way of getting rid of these insects, which appear in large numbers, is to cover the cotton that has been picked with a cloth and in a short time the insects will collect on it.

The States which offer possibilities for an immediate development on a large scale are Rio Grande do Norte, Parahyba and São Paulo. I have already spoken of the Serido district and its environments and therefore need not sav anything further about Rio Grande do Norte and Parahyba. São Paulo, due to its rich soil and phenomenal yields, will certainly produce larger quantities and it seems to me that a good many of the old coffee plantations will be turned into cotton plantations when the price of the latter has again become more luerative to the grower. In the North one generally hears the opinion that São Paulo is unable to produce anything but short cotton, which idea is erroneous. I have seen on the plantation of Mr. Manoel Guedes at Tatuhy cotton up to $32 \mathrm{~mm}$. length, and an acre there gives at least $2 \frac{1}{2}$ times as much as in the U.S.A. : $28 / 30 \mathrm{~mm}$. is quite common in São Paulo.

São Paulo must and can easily satisfy all the requirements of the mills in the South of Brazil. It seems to me a useless loss of money expended in freight on the cotton that is brought from the North to Rio and Santos : not only is it a question of freight and insurance but also the export taxes payable to the States of Parahyba and Pernambuco. São Paulo can produce a good fibre of sufficient length to spin yarn such as the Brazilian mills turn out. Minas and Bahia also can easily supply with their own cotton all that the mills in these States require. A shipper of cotton told we that he had sent one lot from São Paulo to Germany and that his cotton was used there for spinning 3.2's, whilst in São Paulo the same cotton was used for spinning Is"s. It seems to me that generally the Brazilian mills are using cotton of too good a quality for their low counts.

The exportation of cotton from the State of São Paulo can only be taken in hand when the local mills have been supplied and when a proper system of classification, such as exists in the North (Recife, Parahyba and Natal) has been introduced. The European buyer refuses to accept mixed cotton: uniformity of fibre and clean lots are essential factors. 
As regards Minas Geraes, I notiecd a certain predilection for the mining industry. Allow me, however, to call your attention to an indisputable fact, which applies not only to Minas but especially to São Paulo, Parahyba and Rio Grande do Norte, i.e., the existence of real gold mines for the exploitation of which it is not necessary to go deeper into the soil than the depth of a hoe: working the soil with any kind of agrieultural implement will bring forth treasures undoubtedly richer than those of the famous gold mine, "Morro Velho." In thi mine some 3,000 miners are engaged daily and although the conditions under which these people work are the best possible, yet it must be conceded that work in the fields, in the open air, is by far healthiex than working underground, and I feel certain that by employing 3,000 strong men in cotton eultivation, either in the Seridó or in São Paulo, or in fact in any other cotton zone, would in ten years realise greater wealth than has been brought to light during the whole of the existence of " Morro Velho."

Meaxs of Commenication,- Minas Geraes has very rich land, especially along the São Francisco river, but this vast stretch of country will remain of very little value to the world at large as long as the transport facilities are not considerably improved. All agriculture, all progress depends completely on the means of communication. What is the good of fertile land and industrious people if their products cannot be brought to the markets of the world? The traveller on the few steamers plying on this river is constantly impressed by the industry of the people working in the fields that are bordering the banks.

speaking of means of communication, it is my pleasant duty to expresis my admiration for the net of motor roads that have been constructed in the last few years in the States of Parahyba and Rio Grande do Norte. They are already revolutionising the social and economic life of this rast interior, as the exporters are gradually penetrating into the interior and beginning to have their cotton ginned and baled near to where it has been grown. In this way several intermediary agents, who are mostly speculators, are being cut out and the farmer is beginning to obtain a price commensurate with his work.

The World's Cotton Position.-Before terminating I desire to say a few words on the world's cotton position as it presents itself to me at present and in the future. Prices of all raw materials are low through the consequences of the world's poverty eaused by the war, and cotton has not escaped this world's crisis. It is not overstating the ease if one estimates that half the spindles of the world have been stopped dluring the last six months, due to the absence of orders caused by lack of conficlence in the world's political and financial position. But this depressed state of affairs cannot continue much longer and as cotton is the best and cheapest fibre for elothing the poor as well as the rich. it is bound to come in good demand at the first turn of events. New processes invented enable cotton to take the place of silk. Many new industries which are likely to develop on a much larger scale, such as the manufacture of pneumatic tyres, motor-ear hoods, cloth for aeroplanes, etc.. require cotton as one of the most important raw materials ; cotton is also used as a substitute for leather (trunks. shoes, etc.). Before the war there was already a scarcity of cotton. especially of 
long fibre, as has been pointed out repeatedly at the World's Cotton Congresses. The U.S.A., the largest supplier in the world, has evidently come to the extreme limit of its capacity. The high wages ruling there make the growing of cotton unremunerative and we were told on the authority of the President of the Cotton Farmers' Union that the American cotton farmer would no more continue to allow his wife and children to work in the fields. With such fantastic ideas it cannot be expected that there will be an increase in the cotton acreage of the U.S.A. The boll-weevil is still forging ahead in the Cotton Belt of the U.S.A., so much so that there is hardly any Sea Island cotton left, and of late there has been an invasion of the pink boll worm.

Those European countries that have Colonies in Africa and Asia are using every effort to introduce or to extend cotton growing in their Colonies, where it is frequently necessary to have recourse to expensive irrigation works and to teach the people the value of work. All this is done in the sure expectation that cotton will again be in great demand as soon as the world's eonditions have become once more normal.

Brazil possesses all the natural possibilities. In the States of São Paulo and the North you have land which yields much more than the best cotton lands extant: the climate is also suitable and the area which can be planted with cotton in Brazil is larger than that of any other country. As the fruits of the reforms suggested in this paper will not appear immediately, but will take scme time to mature, it is necessary that you take immediate steps and not wait until this great demand for cotton is at hand. As I have pointed out, unless you set to work at once with regard to seed improvement and the control of ginneries your cotton growing industry is bound to deteriorate from year to year.

As it has not been possible for us to visit the remaining cotton growing States in the North, from Ceará to Pará, I shall have much pleasure to suggest to my Committee that a similar Mission be sent next year to do this work, if your Government should desire it to be done.

I avail myself of this opportunity of expressing publicly the gratitude of the International Cotton Mission for the cordial reception and hospitality which you have shown to them in all parts of your country. I have travelled in many countries, but never have I come across such good-hearted people, so generous, as I found them in Brazil : especially in the Seridó I met with real touching cordiality from both rich and poor.

Finally, I express our deepest sense of gratitude for the hospitality which was dispensed to us by the Govermments of the various States which we visited. We stood in need of nothing. Our sincere thanks go out especially to the Federal Government, with which I couple the name of His Excellency, the Minister of Agriculture, for attentions and favours which were granted to us by the Government through the Cotton Department by the Superintendent or his Delegates in the various States; we greatly appreciated the advantage of having one of the Agricultural Staff accompanying us on our journey. For all these amiabilities pray accept our profound gratitude. 
This terminated the address of Mr. Pearse and Mr. Lyra Cistro expressed to the lecturer the thanks of the Society. He also explained that the President-Mr. Miguel Calmon-owing to illness was unable to be present at this interesting meeting.

Mr, Lyra Castro stated that the Society had, for a long time, shown interest in the improvement and development of cotton eultivation, having in 1916 initiated and organised the Cotton Conference from which resulted various recommendations, some of which had a gain been emphasised by Mr. Pearse.

It had indeed been a pleasure to him to have heard from such an authority advice which in so many directions confirmed the steps suggested in these resolutions, some of which had been executed by Public Bodies and the balance of the resolutions they were pressing hard to see them become effective.

Mr. Lyra Castro referred to the steps taken by the present Government through the Ninistry of Agriculture, which was in the hands of a devoted and experienced agriculturist who had cotton at heart, and after referring to the Cotton legislation initiated recently by the Cotton Department of the Government pointed out that some time would elapse before Brazil would enjoy the fruits from this organisation and before the National welfare would benefit.

Mr. Lyra Castro, upon terminating his remarks, expressed again on behalf of the National Agricultural Society sincere thanks to $\mathrm{Mr}$. Pearse. He also thanked the audience for the most attentive manner in which they had listened and expressed his satisfaction at seeing present the Ministers of Agriculture and War, as well as many Senators, Deputies and other Members who, by their presenee lent added honour and charm to the occasion.

His Exeellency the Minister of Agriculture again spoke, expressing his high appreciation for the simple, natural and very instructive lecture delivered by the representative of the International Cotton Mission. He continued: "Those who know the resolutions of the Cotton Congress and the steps taken by the Government since the organisation of the Cotton Department will, no doubt, realise that the Government is carrying out the programme outlined. Brazil is a very vast country. Mr. Pearse has only seen 1,000 plantations, whilst we have to calculate with millions. which shows that the improvement of our position depends on many varying elements, often beyond the action of the Ministry."

His Excelleney then referred in a general manner to the special legislation needed, to the alteration of systems required owing to more modern processes and to the difficulties of introducing these over so vast an area. He assured the audience that all this would be overcome, but he thought that besides official action it would be a great advantage if private initiative were to co-operate and that the collaboration of such highly appreciated experts as the lecturer to whom the audience had listened was a great step towards their realisation.

The Minister then dwelt upon the great benefits which are bound to result from the manner in which the Mission had carried out its work, ealling meetings of farmers, merehants, prefects and all interested 
parties, by having a frank talk with these people, and by the various lectures given in the centres of industry, a great educational work had been performed, which was of inestimable value for the promotion of cotton growing.

The Minister continued: "In the name of the Government I thank again Mr. Pearse and his colleagues of the Mission for the honourable visit and for the beneficial advice given in his lecture which the National Agricultural Society will have printed in a large edition and circulated all over Brazil, a step which will undoubtedly co-operate towards the economic improvement of the country."

He further spoke of the important rôle which England occupied in the cotton industry. Indeed, lre said, Lancashire might be called a past-master of cotton spinning. England is a leading country in the organisation of the International Cotton Federation and he congratulated this Corporation for having readily consented to send this Mission.

Terminating his remarks he again thanked the Mission and those who had been good enough to accept the invitation of the Society, signalling out the presence of the Minister of War, through whose action when President of the Brazilian Commercial Mission that visited England, must be attributed the fact that the Pearse Mission came to Brazil.

Addressing himself to the Minister of War, he said: "It was indeed on the occasion of a banquet offered to your Excellency in Manchester that this very idea suggested itself after the honourable discourse pronounced by the great leader of the cotton spinning industry of Lancashire the late Sir Herbert Dixon, Bart.-and we well remember the brilliant response which Dr. Callogeras made.

This terminated the meeting. 


\section{INDEX}

Acary (Seridó) $\ldots \quad \ldots \quad \ldots 146,152$

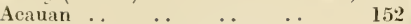

Açudes (rescrvoirs) General, . . $\quad 134$

São Antonio, Acary, Caicó.

Curraes Novos, Floreo, Jar- 145, 146

dim do Seridó, Serra Neora

Cruzcta $\ldots$.. .

Gargalheira ... $\quad \ldots \quad$..

Parelhas … $\ddot{\text { Bahia }) . .}$

Aceount Sales Cotton (Bahia)..

Acre, Tervitorio do .. ..

Afforestation $\ldots$.. $\quad \cdots$

Agate .. ... . .

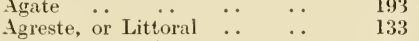

Agricultural Iabour, scarcity . 149, 150

Agricultural Products .. $\quad . . \quad 177$

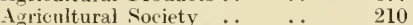

"Agro" Cia Fabril Mercantil. . 34

Agua Branca (Biriguy) $\quad$. $\quad \$ 6$

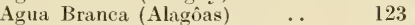

Aguas Bellas (Pernambuco) .. 130

Alagôa do Baixa (Pernambuco) 130

Aligôas: General Cotton Growing $56,123,124,126,219$

Population, Area, Railways 13, 19, 123

Vlagoinhas, Verdão .. . I

Albrecht \& Co., F., Liverpool

Albuquerque, Col. Franklin Iins d'

Aleantara (Maranhão) . . . .

Alfalfa $\cdots \quad \ldots \quad$. . .

Algodão Sylvestic $\quad \ldots \quad \ldots, 51, \quad$ 150

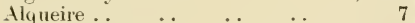

Amazon River .. $\quad \ldots \quad$. . $\quad 19$

Amazonas, State of $\quad \ldots \quad \ldots \quad 13,19$

Amazonas (R. G. do N.) .. 14.5

America Fabıil.. $\quad$. $\quad \ldots \quad \ldots$

American Cotton (São Paulo) (set also "Herbaceous) ..

Anadia .. .. .. ..

Angicos .. $\quad \ldots \quad \ldots$..

Anjos, M. Alfiedo dos ..

Annapolis Annual Cotton (see São Paulo and Herbaceo) ... ..

Apertado, Fazendiı $\quad \ldots$..

$\begin{array}{lllll}\text { Aquirlaban } & \ldots & \ldots & \ldots & 121\end{array}$

Aracaju . $\quad \ldots . \quad \ldots . \quad \ldots, 12: 2, \quad 209$

Aracatuba, Fazendia . . . . $\quad$ ss

Aracaty (Ceará) Cotton Merebants 144

Araguary . .. . . .

Arassuahy (Minas) Cotton Zone

Areado Pilão .. .. . .

Area, Alagôas .. $\quad$.. ..

Bahia $\quad \ldots \quad \ldots \quad \ldots$

Brazil $\ldots \quad \ldots \quad$..

Minas Geraes ... ..

Parahyba $\quad$. . .

Pernambuco ... ..

Rio Grande do Norte..

Scrgipe .. .. ..
145

Automobile Roads $131,159,165,221$

"Azul" (see Riqueza, Verdão) 143

Bacabal (Maranhão) . . . .

Bahia :

Area, Population and Rail-

"Centro Industrial to $13,19,105$

Centro "

$11 \mathrm{~s}$

Commercial Association .. $\quad 118$

Cotton Imports .. $\quad$. $\quad 106$ sold to Bahia Mills. $\quad 106$

Kones $\quad \ldots \quad \ldots \quad 106$

Future Cotton development $\quad 56$

Geographical Notes. .. 105

Baixa-Verdão, Verde.. .. 141

Baixo Land .. .. .. 148 , at Bonita, at Epinal 151

Bale Press, Hydraulie . .. $\quad 88$

$\begin{array}{lllll}\text { Limoeira } & \ldots & \ldots & \ldots & 129\end{array}$

Pernambuco, density $\quad$. $\quad 166$

Primitive Hand Press .. 101

Balls, Dr. W. I. $\quad$. . $\quad \ldots .11,159$

Bandeirantes .. $\quad$.. $\quad \ldots .70$

Barão do Grajahí (Maranhão) . 159

Barão do Rio Branco .. . . 128, 130

Barboza \& Co., Campina .. 173

Barragem Gargallucira . . . $\quad 152$

Barra (Bahia) .. $\quad . . \quad \ldots .106$

Barra do Rio Grande . .. 111

Barra do ('onda (Maranbão) .. $\quad 159$

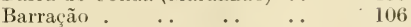

Barreiras.. $\quad \ldots \quad \ldots \quad \ldots \quad \ldots \quad 106$

Barrero Grande (Volta Grande) 109

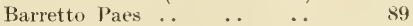

Beans .. . . . . 104, 136, 189

Bello Horizonte (Minas) .. 95, 201

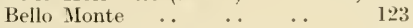

123 Benjamin Constant .. $\quad$.. $\quad 159$

142 Berthet, Dr. J. J. Aithaul .. \$2

99 "Big Boffe" (Minas) .. . . 96

121 Big Boll . . . . . . .

Biriguy $\ldots \quad \ldots \quad \ldots \quad \ldots \quad \ldots \quad 84,89$

Bleached Cutton Piece Goods,
Imports of .. $\quad \ldots \quad \ldots$

$\begin{array}{lllll}\text { Boa Vista } & \ldots & \ldots & \ldots & 14 \%\end{array}$

Board of Immigration and Colonization . .. $\quad$.. 15

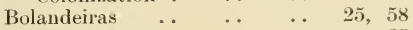

Boll-Weevil . . $\quad \ldots \quad \ldots . \quad \ldots 5$

95 Bomfim (Bahia) $\quad \ldots{ }^{\circ} \quad \ldots 106,116$

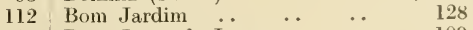

123 Bom Jesus de Lapa .. $\quad$.. $\quad 109$

105 Bom Jesus dos Meiras. .. 106

13 Bonita (Seridó) . . . . $\quad 151$

91 Borges, F. de Andrade (Mossoró) 144

132 Boris Frères (Shipping Marks) 166, 169

127 Boxwell \& Co., Pernambuco .. 166, 169

132 "Braça" . . . . . . 4

119 Braga, Cinciuato .. $\quad \ldots \quad 10$ 
Brazil : Area and Population . . Climate $\because \quad \ldots \quad$. Exports of Cotton from .. Importance of Cotton to .. Industries . . . . Brazilian Characteristics .. Brejo (Maranhão) .. . . Brejo da Madre de Deus .. Brejo do Apody .. .. Bridge, David \& Co., Ltd. . . Brito, Luiz Agatangelo (Caicó) Britto, José de, (Campina Grande) "Buenos Aires" (R. G. do N.) Buique .. $\quad$. $\quad$. $\quad$. Buley, E. C. .. $\quad$. $\quad$. Buquerão de Parelhas . . . $\begin{array}{lll}\text { Buquim } & \ldots & \ldots \\ \text { Burity (Maranhão) } & \ldots & \ldots\end{array}$ Butantan, Snake Institute ..

Cabral, Pedro Alvares . . . Cachaça . .. . . . Cachoeira (Rio Grande do Norte) Cactus Trees .. .. .. Caetano .. . . . . . Caeteté (Bahia) . \# .. $\ldots$ Caieó (Seridó), Açudes, Cotton
Production, Population, Merchants .. .. .. Calda de Canna. . . $\quad$. Calmon, Miguel … .. Callogeras, Dr., Minister of War Camargo, Clovis . . . . . Camello, Fazenda, Mocó Yield. . Campina Grande . . . Campinas (São Paulo) . Campo Largo ... .. . . Campo do Britto .. .. Campo Grande .. . . . . Campos .. $\quad . . \quad \ldots \quad \ldots$ Canastra Mountain .. .. $\begin{array}{llll}\text { Cannabrava } & \ldots & \ldots & \ldots\end{array}$ Canto Alegre $\ldots$.. $\quad$.. Capão Alto $\quad$. $\quad$. $\quad$. $\begin{array}{lllll}\text { Capella } & \text {. } & \ldots & \text {. } & \text {. }\end{array}$ Capim panasco $d$. $\begin{array}{llll}\text { Capital employed in Mills } & \ldots 196 \text { to } 223 \\ \text { Carahubas (Verdão) } & . & . & 144\end{array}$ $\begin{array}{lllll}\text { Caravonica } & \text {. } & \text {. } & \text {. } & 130\end{array}$ $\begin{array}{lllll}\text { Carbonate } & \ldots & \ldots & \ldots & 192\end{array}$ Carnauba Palm, Wax of $111,113,189$ Carneiro, Dr. Octavio . . . 100 $\begin{array}{lllll}\text { Carinhanha } & . & . & \ldots & 107\end{array}$ $\begin{array}{lllll}\text { Caruarú .. } & \ldots & \ldots & \ldots & 128\end{array}$ Carvalho, Dr. Ignacio Joaquim Casa Nova $\quad . . \quad \ldots \quad \ldots 106,114$ $\begin{array}{lllll}\text { ('astillôa .. } & \ldots & \ldots & \ldots & 187\end{array}$

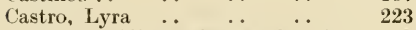
Catharins, Alberto Mloraes Martins 118 $\begin{array}{llllll}\text { Catingueira } \quad . & . & \ldots & 77, & 133\end{array}$ Catingueira (Rio Grande do Norte) 145 Catonì (Minas) .. $\quad$. $\quad \ldots \quad 95$

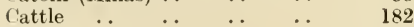

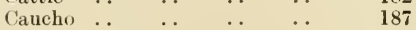

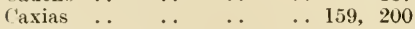
3 rative size of Brazil .. Comparative Cotton Yields .. ('omparative Output, Roller and Saw Gins .. .. .. Compensation, Hill Operatives Composition, Brazilian Race .. Concession. Terms for Ginning Conseription .. .. .. Constitution $\quad \ldots \quad \ldots \quad \ldots$ Consumption $\begin{array}{lll} & \cdots & \ldots\end{array}$ Conto de réis $\ldots \quad \ldots \quad \ldots$ Co-operative Societies... . . Co-partnership .. $\quad \ldots \quad \ldots$ Copper . $\quad$. . $\quad$.. Coroatá (Maranhão) $\quad$. $\quad$. $\begin{array}{llll}\text { Correntes. } & \ldots & \ldots & \ldots\end{array}$ Cost of Fences . . . . Cost of Land in São Panlo ... ('ost of Reservoirs .. ..

PAGE

('eacá: Area, Population, Railways 13, 19 $57,134,149$

149

41, 118

27,41

42 $4 \mathrm{I}$ 185 107 1.59

20

32

111

10

70

84

118

133

220

120

10

16,17, Is . 39,189 .. $\quad 185$

. 159,200

9,219

$93,104,220$ 220
123 145

15,93 118 133 74

176,216

81

98

13

87,88

62

32

14

$59, \quad 129$

44

22

24

216 
r'ost of Roller Cins

('osta Lima and Mirtyl, Aracaty

Cotton: Ameriean .. .. Commereial elassifieation .. Dirty . .. .. .. Exports of Raw .. .. Frowing Early History .. Profit in Seridó...

Illustration of staples ..

Importanee to Brazil .. Laek of Knowledge .. Mill Consumption .. . . Pests . .. .. ..

Shortage of Long Staple..

Cotton Mills: Children in, Working Hours 34 Dividends .. .. . . 4

General C'onstruction . . $\quad 29$

Summary $\quad \ldots \quad \ldots 25,27,28,196$ Wages $\quad \ldots \quad \ldots . \quad \ldots \quad 33,34$ Welfare Work $\quad . \quad \ldots \quad \ldots 30.43$

Cotton Groods : Exports $\quad . .5050$ $\begin{array}{lllll}\text { Imports } \quad \ldots & \ldots & \ldots & 45,49\end{array}$ ('otton Production $\quad \ldots \quad \ldots, 52,21$. Counts spun .. . . 28, 29, 122, 219 ('ovas (yield per cova). .. 143 ('reighton Opener $\ldots \quad \ldots 169,217$

Crioulo Cotton .. $\quad .97,114,122,21 !$

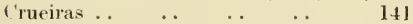

Cruz, Dr. Oswalko $\quad \ldots \quad \ldots .218$

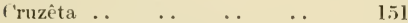

"Cultura do Algodeiro no Brazil" 10

Curuquerê (cotton wor'm) ..

$\begin{array}{lll}\text { Curraes Novos (Seridó) } & \text {. } & 146\end{array}$

Curralinho (Maranhão) . $\quad$. . $\quad 159$

('ururipé (Alagôas) $\quad$. $\quad \ldots .126$

Cururupú (Maranhão) . . $\quad$.. $\quad 158$

Curvello (Minas) _. . . 95, 201

Damp Cotton .. $\quad \ldots \quad \ldots \quad \ldots \quad 32$

Delintering Nachine ... . 129

Denis, Pierre "Brazil",

Density of Cotton Bales .. 129, 161

Density of Population.

Department of Agriculture.

"Descaseador","

"Despolpador ",

Destination of Exports ..

Destination Ports-Piece Goods

Dettmann, E. .. ...

Diamonds ... .. .

Difficulties of Travel .. ..

Dirty Cotton .. ..

Discovery of Brazil .. .

Distances in North-East-. Motor Roads

Dist. da Carira

Dividends, Cotton Mills

Dohson \& Barlow, L.t. ..

Dom João and Dom Pedro...

Dôres ... Cotton ('ultivatio

Drawbacks to Cotton Cultivation-

Droughts

Dutch in Brazil . $\quad \ldots . \quad \ldots \quad r, 21$

Duty, Import .. $\quad \ldots \quad \ldots . \quad 40$
PAG:

Dyed Goods. Jmport of .. $4 \mathrm{~s}$

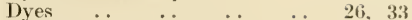

"Eagle" Saw Gins .. .. is, 140

Economic Notes on Brazil .. 10

Egypt, Area, Yields .. . . $\quad 54$

Eleetrieity, eost of . . . . $\quad 3 s$

Elysio, Felinto (.J. đo Seridó).. $\quad 152$

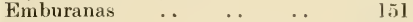

$\begin{array}{lllll}\text { Engenhos . } & \ldots & \ldots & \ldots & 179\end{array}$

Entrepot Cotton Warehouse, Seroipe 120

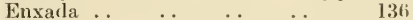

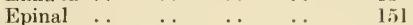

Epitacio, Pessôa, Jr. President 9

Espirito Santo .. $\quad . . \quad 13,196,200$

Espirito Santo, Volta do .. 153

Estancia . . . . . . 121, 209

Euealyptus Trees .. .. 40 40

Fxehange, Rates of $\ldots \quad \ldots \quad 19$ t

Exports-Beans, Cattle, Chief C'ommodities, Coeoa, Coffee.

('otton, Frozen Meat,

"Herva Matć," llides,

Indian Corn, Mandioea,

Minerals, Riee, Sugar 65, 90, 177 to 190 Export Tax $\quad \ldots \quad \ldots 24,120,125,128$

Fawcett, Preston \& ('o. $\quad$.. $\quad 166$

Federal District . . . 13, 196, 199

Feijão preto, mulatinho, exports 159

$\begin{array}{lllll}\text { Feijoada... } & \ldots & \ldots & \ldots & 189\end{array}$

Felinto Elysio (J. do Seridó) .. 152

Fences, Wicker, Stone, eost 131, 1.it), 156

Fereira, João de Almeida .. 144

Fernandes, Alfredo (Mossoró). . 144

Fernandes \& Cia, Tertuliano 144

Ferrario, G. (Iona \& C'ia) .. $\quad 37$

Figueiredo, Camillo (Mossoró). . 144

Finishing Departments-Mills . 33

First Aid Rooms- llills .. 4 42

Fishing at Chique-Chique .. 111

Flôres-Population, Cotton Production .. . . . $\quad 146$

Folha, Algodão em ... $\quad$. $\quad 172$

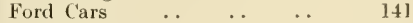

Foreigners' status in Brazil .. $2: 3$

Formigo (Minas) ․ .

Fornazaro, Feo (São Paulu) . .

Fortuna

Fraudulent Packing .. $\quad$. 129, 144

Frozen and ('hilled Neat .. 182

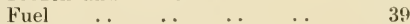

Fumigating Cottom Seed . .

64, 130 Gaes, 1)r. Paulino d'Aranjo .. 11.5

21 "Ganga" Cotton .. . . 51, 150

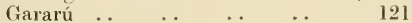

$\begin{array}{llllll}172 & \text { Gargalheira } & \ldots & \ldots & \ldots & 152\end{array}$

121 Garranhuns .. . . 124, 128, 174

41 General Cotton Remarks 52, 69, 139

36 Geography $13,69,105,119,123,127,132$

21 Geological Constitution (Seridó) 148

Geremoabo .. .. .. 106

Ginning: "Bolandeiras," Defective, In Egypt, In Peru,

Modern, Saw and Roller,

Table of Faetories, Tax 55 to 62,89 
Glehn \& Co., Alex. von, Liverpool PAfr 171

Gloria do Goytá $\quad$. . $\quad$.. $\quad 128$

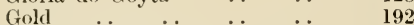

Gonzaga (Maranhão) .. $\quad$. $\quad 159$

Gorgonio, Ambr. da Nobrega . .

Gouveia, Delmiro ... ..

Government of Brazil .

Goyaz .. .. .

$$
\text { is }
$$

Grading Cotfee $\cdots$

, Cotton . $\quad$.. .

Grajahú (Maranhão) $\quad \ldots$

Grande Secca .. .. .

Green, Professor .. .

Guapapá . .. $\quad \ldots$

Guedes, Manoel.. $\quad$..

Guimarães (Naranhão) . . . $\quad 158$

Hair Length $\quad . \quad \ldots \quad \ldots \quad \ldots \quad 165$

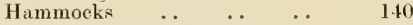

Hand Loom Industry . . . $\quad 25$

Handling of Cotton .. $\quad \ldots .166$

"Herbaceo" .. . . $\quad 79,9 ;, 129$

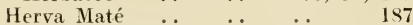

Hesse Wartegg, F. von .. 10

Hevea Brasiliensis .. .. 186

Hexagonal Sieve $\quad \ldots \quad \ldots, 121,217$

$\begin{array}{llllll}\text { Hides } & \text {. } & \ldots & \ldots & \ldots & 194\end{array}$

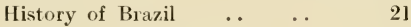

Horto Florestal Joazeiro .. 115

Hospitality $\quad \ldots \quad \ldots . \quad \ldots 9,12,140$

Howard \& Bullough's ()pener . 128

Hybridization . . . $\quad \ldots \quad 139,214$

Hydraulic Press . . .8?, 129, 166, 176

Hydro-Electric Plant . . . . 35, 38

I rnacio Joaquim de Carvallo filho 149

Iguatú (Ceará) . . $\quad \ldots \quad \ldots \quad$ 159, 175

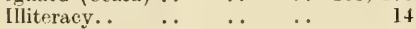

Immigration-Subsidy-C'om position $\cdots$ Piece Goods

Imports : Cotton Piece Goods 44 to 48 Cotton Yarns

Excise Duty on Cotton

$$
\text { Goods ... .. .. }
$$

Increase of Population . ..

Indian Corn $\ldots 73,104,113,136,1 \times 9$

indigenous Cotton .. ..

Industries of Brazil .. ..

Inhapi .. $\quad \ldots \quad$..

Insect Pests $\quad \ldots \quad \quad \ldots \quad \quad$ (33, 140, 220

Instituto Agronomico, Campinas 82

Inteiro .. .. .114, 133, 155, 219

International Cotton Committee

International Cotton Congresses

Iona \& Cia.

12

.

37,124

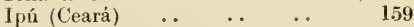

Ipueiras (Ceará) . $\quad$. . $\quad \ldots . \quad 159$

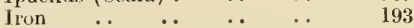

Irrigation $134,143,151,152,154$

Itabaiana (Servipe) ... .. 121

Italian Cotton Mill Operatives. .

Itapecurú (Maranlião) .

Itapeteninga (Sío Paulo)

42

159

Paulo) $\quad$.

Itaúna (Minas) .. $\quad$.. ..

Itinerary
Ití

$\begin{array}{lllll}\ldots & \ldots & \ldots & \ldots & 206\end{array}$

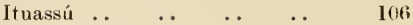

$\begin{array}{llllll}\text { ltuiba } & \ldots & \ldots & \ldots & \ldots & 117\end{array}$

Jacaré .. . . $\quad \ldots \quad \ldots 3$

Jaguaribe Valley (Ceará) 161, 144, 162

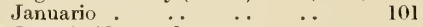

Japoré, Manga de $\quad . . \quad \ldots \quad 103$

$\begin{array}{lllll}\text { Japaratuba } & \ldots & \ldots & \ldots & 121\end{array}$

Jardim do Seridó $\quad \ldots \quad \ldots 146,152$

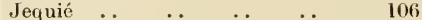

Jenny, Fritz $\quad \ldots \quad \ldots . \quad \ldots 9,11,211$

Joazeiro (São Francisco) .. 114

Joazeiro, Fazenda .. . 142,155

$\begin{array}{lllll}\text { Junqueiro } & \ldots & \ldots & \ldots & 112, \\ & & \end{array}$

Khaki Cotton . . $\quad \ldots \quad \ldots \quad \ldots \quad 155$

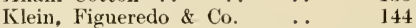

Knitting Department, Wages . 34

Kroencke \& Co. $\quad . . \quad 9,166,170$

Labour-Agricultural . . . . 149, 150

Lace Making . $\quad \ldots . \quad \ldots, \quad 102$

$\begin{array}{lllll}\text { Lagarta .. } & \ldots & \ldots & \ldots & 121\end{array}$

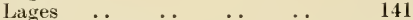

Lagôa de Algodão $\quad$.. $\quad$.. $\quad 124$

Lagôa de Piato.. $\quad$.. $\quad \ldots . \quad 143$

Land-Cost of : In Biriguy .. $8 \tilde{5}$

In São Paulo $\quad \ldots \quad \ldots .77$

In Seridó $\quad \ldots \quad \ldots \quad \ldots \quad \ldots \quad 150$

Land Measurements $\ldots \ldots \quad \ldots 7,94,122$

Lefroy, Maxwell $\quad . \quad \ldots \quad \ldots, \quad 65$

Leitão \& Co., Campina Cirande $\quad 172$

Lenções do Rio Verde . . . $\quad 95$

Length of Fibres $\quad \ldots \quad 79,164,220$

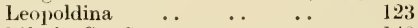

life in Sertão .. $\quad \ldots . \quad \ldots \quad 140$

Light and Power (co., Sorocaba 29, 38

Limoeira (Pernambuco) 123, 128, 174

Limoeiro (Ceará) $\quad$. $\quad \ldots . \quad 159$

Lins. d'Albuquerque, Col. . . 112

Linters, Mixed with Cotton .. 129, 218

Littoral Cotton Zone .. $\quad . . \quad 133$

Luans employed in Mills .. $\quad 196$

Lobo. Eng. Col. Pereira .. 120

Long Staple Cotton Shortage. 53

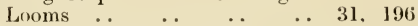

Lopes, Ildefonso Simōes $\quad 9,210,213$

Luiz Agat, de Brito, Caicó .. 149

Luiz de Queiroz School _. 65, 83

Macarthy Gins (see Ginning).. 216

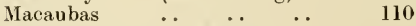

Maceió (Jaragua) (Mills) $\quad$.. $\quad 197$

llacFadden \& Co., Philadelphia, U.S.A. $\quad$. $\quad \ldots \quad 66$

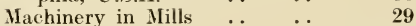

Making-up Depts. in Mills .. 33,41

$\begin{array}{lllll}\text { Mlalhada... } & \ldots & \ldots & \ldots & 107\end{array}$

Malhada da Arreia $\quad \ldots \quad \ldots . \quad 153$

Malva Plant .. $\quad \ldots \quad \ldots 133,136$

Mandioca . $\quad \ldots \quad \ldots \quad 104,113,189$

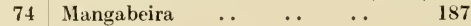

201 Manganese $\quad \ldots .037$

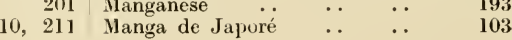


PACE

$\begin{array}{lllll}\text { Maniçola } & \ldots & \ldots & \ldots & 186\end{array}$

Maraeajá, Virgilio $\quad \ldots \quad \ldots \quad 173$

$\begin{array}{lllll}\text { Maracanahú } & \ldots & \ldots & \ldots & 145\end{array}$

$\begin{array}{lllll}\text { Maracás . } & \ldots & \ldots & \ldots & 106\end{array}$

Maranhão :

Area, Population and Railways $\because \quad \ldots \quad \ldots$

$13, \quad 19$

Cotton Distriets $\quad \ldots \quad \quad \ldots 158,219$

"Maranhão" Cotton .. $\quad$.. 124

$\begin{array}{llll}\text { Markets-Loeal . } & \ldots & \ldots & 215\end{array}$

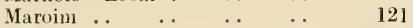

$\begin{array}{lllll}\text { Matto Grosso } & \ldots & \ldots & \ldots & 13\end{array}$

"Matta" Zone . . $\quad$. $\quad 133$

Measures . $\quad \ldots \quad \ldots . \quad \ldots 8,94,122$

Medeiros, Trajano S. V. de $97,128,174$

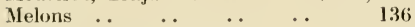

Mendes, Dr. Carlos Teixera .. 65

Mendes, Lima \& Co. .. . . 166, 171

Method of Sale-Cotton Goods 40

$\begin{array}{llll}\text { Methuen Treaty . } & \ldots & \ldots & 26\end{array}$

Milking-Illustration _. $\quad$. $\quad 183$

Mlills, List of .. $\quad$. $\quad$. 196

Minas Geraes :

Area. Population and Railways $\ldots \quad \ldots \quad \ldots 13,19,94$

Commodities of Export ..

Geography, Ginning at Pirapora, Future Development, Varieties of cotton .. . . .

Minas do Rio de Contas ..

94 to 98

106

191

$\begin{array}{lllr}\text { Mlirador (Maranhão) } & \ldots & \ldots & 159 \\ \text { Miuda (otton .. } & \ldots & \ldots & 97\end{array}$

Mixture of Seeds $\quad \ldots \quad \ldots 152,217$

Mixtures of Varieties .. 116, 152, 212

llocó Cotton : General Remarks 130, 139

Physical Qualities .. $\quad . . \quad 159$

Yield . $\quad . \quad \ldots \quad 139,143,146$

Mocozinlıo Cotton 139, 150, 153, 162

Model Village .. $\quad . . \quad \ldots .37,43$

Mohammedan Influence .. 14

Monazitie Sand . . $\quad$. . 193

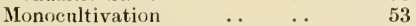

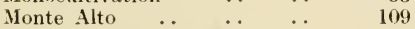

Monte \& Co., F. de (Mossoró). . 144

Monteiro \& Co., José Ign. . . 173

Montes Claros .. $\quad \ldots \quad \ldots \quad 95,202$

Morada Nova (Ceará) . . $\quad . . \quad 159$

Horro do Chapeo .. . . 106, 11 s

Morro Velho .. $\quad . .4 \quad \ldots$,21

Hortality, rate of $\quad \ldots \quad \ldots . \quad 17$

$\begin{array}{lllll}\text { Mossoró } . . & \ldots & \ldots & \ldots & 143\end{array}$

Motor Roads $\quad \ldots \quad 131,134,156,157$

Mudubim . $\quad . \quad \ldots \quad \ldots \quad \ldots \quad 143$

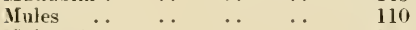

$\begin{array}{lllll}\text { MInlungú } & \ldots & \ldots & \ldots & 145\end{array}$

Mundo Novo, Rio de .. . . $\quad 150$

Munger, Huller Gin-Dallas .. $\quad 129$

$\begin{array}{llllll}\text { Muricy } & \ldots & \ldots & \ldots & \ldots & 123\end{array}$

Natal (Rio Grande do Norte) 141, 163, 220

National Agricultural society. . 12, 210

National Museum--Rio .. 52

Nationalities of Immigrants .. 15

Navigable Rivers
Navigation- Sĩo Francisen

Nazareth. Jo(i, ].) ]

Nobrega, $F(0)$. Corg. da .. lis

Nova Pussos (C'eará) . . . . $\quad 15 !$

Nova York (Matranhão) .. 1,i!

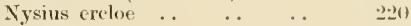

Oakenfull, ,I. ( . . . . . . 10

Oil Pressing Plants .. $\quad 39,9 x, 1$ is

Olhos d'Agua do Acioli .. 126;

Opening Machinery .. .. 125, 169

Operatives-Mill $\quad \ldots \quad 32,42,196$

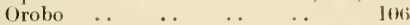

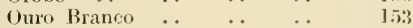

Ownership of land $\quad \ldots \quad \ldots 76,8(), 8, j$

Packing-Frandulent . . . . 129, 21s

Palmeira dos Indios . . . . 12:3, 1:6;

Pão d'Assucar . . . . . . 123, 124

Pará-State of .. $\quad \ldots \quad 13,19,159,222$

Paracatú . . . . . $\quad$. $\quad 99$

Paraliyba :

Area, Population and Railways 13. 19

Cotton firowing . . . . 132

Geography $\quad \ldots \quad \ldots . \quad \ldots 132,221$

Paraná .. $\quad \ldots \quad \ldots 13,19,196,203$

Parasites . . . . $\quad 64,65,2211$

Parelhas, Buquerão de . . . 154

Parnahyba (Maranhão) . . $15 !$

Passagem Franca (Maranhão) . 15!

Pastos Bons (Malmhão) . .

Pata Choea

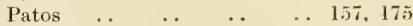

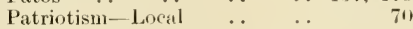

Patrocinio do r'oité $\quad \ldots \quad$.. $\quad$ lokj

Panlistas . . . . . . $\quad 7(1)$

Paulo Affonso (Alagoas) $\quad$. $\quad 123$

Paulo Affonso Fall .. . . . $\quad 34$

Peat Fucl . . . . .

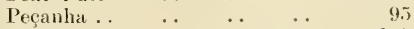

Pedra Branca ..

Pedra (P. Affonso lialls) $34,36,124,195$

Pedras das Abelhas .. .. 144

Pedreiras (Maranhão) . . . 1 I

Pelucho (see also Riqueza, $\begin{array}{lllll}\text { Verdão) } & \text {. } & \text {. } & \text {. } & 1 \text { 14 }\end{array}$

Penêdo .. $\quad \ldots . \quad \ldots \quad$.. $123,-198$

Pernambuco:

Area, Population and liailways $\ldots \quad \ldots \quad \ldots 13,19,127$

Cotton Exports, Tax .. Jes

Port (Recife) .. .. Is

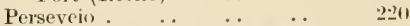

Pessôa, Dr. Eupitacios, President !

Pests $\ldots \quad \ldots \quad \ldots \quad$ 64, 220, 202

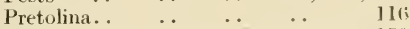

Physical Aspects-Mocó Ciuttons 159)

Piauhy .. $\quad \ldots \quad 13,19,159,196,204$

Picking .. $78, \times 0,125,140,155,215$

Picos (Maranlão) .. . . $\quad 15$ !)

Piece froods-Imports-Exports 4.5 to 50

Pilão Arcado .. .. . . 112

Pilar (Alagôas) . $\quad \ldots \quad \ldots, 1 \geqslant 3,197$

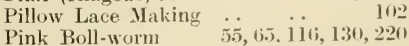

Pink Boll-worm
Pinto, Alves \& Co. 6.5. $11(i, 130,220$
. $160,170,180$ 


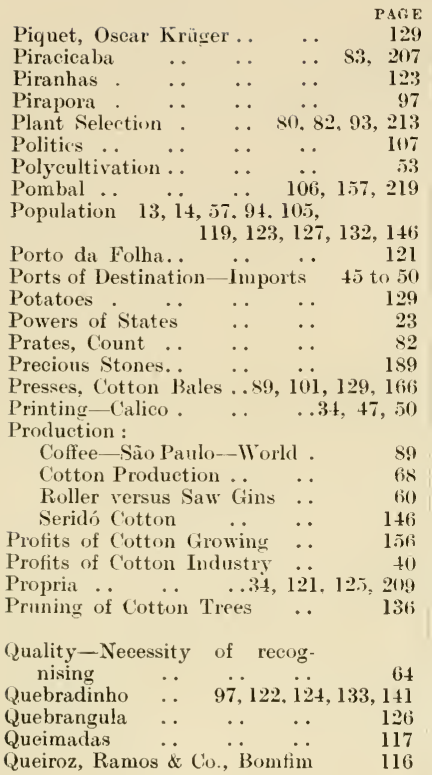

Race-Composition of . . 14 Railways.. $\quad \ldots \quad \ldots 19,117,142,157$ $\begin{array}{lllll}\text { Painfall .. } & \ldots & \ldots & \ldots & 17\end{array}$ Rates of Exchanges .. $\quad$.. $\quad 194$ Rawlinson, Müller \& Co. $\quad \ldots \quad 79,81$ Raymundo de Araujo, Feo... $\quad 151$ $\begin{array}{lllr}\text { Piéal, Reis } & \text {. . . } & 7 \\ \text { Pecife (see Pernambuco) } & \ldots & 220, & 223\end{array}$ $\begin{array}{llll}\text { Reference Books .. . . } & 10\end{array}$

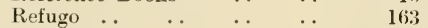
Remanso.. .. . . . 106, 113 Reserves of Cotton Mills .. 196 Reservoirs $\quad \ldots \quad 131,134,146,154$ Resolutions (Internat. (ommittee) II

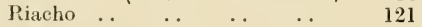
Riacho da Varzea Alegre .. $\quad 156$ Riacho de Sant' Anna. . . 109 Riacho do Meió . $\quad . \quad \ldots . \quad 151$ $\begin{array}{lllll}\text { "Tatú } & \text { T } & \ldots & \ldots & 157\end{array}$

$\begin{array}{llll}\text { Riacho dos Gatos } & \ldots & \ldots & 156\end{array}$

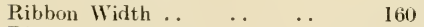

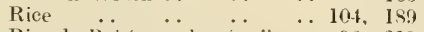
Rim de Boi (see "Inteiro") . 96, 219 Rio Branco . . . . . . $\quad 110$ Rio de Janeiro $\quad$ . .9, 13, 18, 196, 205 Rio dos Pandeiros .. .. 101 Rin Grande (São Franeiseo) . . 98 Rio Grande do Norte

$13,19,132,196,204,220$

Rio Grande do Sul . . 13, 19, 196, 204

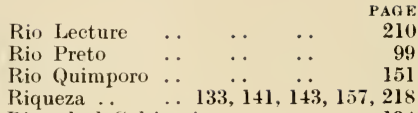

River-bed Cultivation.. ... 134

River Shipping . $\quad . \quad \ldots . \quad . \quad 19$

Roads (Motors) 131. 134, 136, 151, 171, 221

Rock Crystals .. .. . . 193

Roller Gins $\quad \ldots \quad 60,62,140,156,172$

Rompe-Letras (Verdão) .. 218

Root of Cotton (Seridó) $\quad$. 151

Rossinha, Fazenda . $\quad \ldots \quad 75$

Rubber .. $\quad \ldots \quad \ldots \quad \ldots \quad 53,186$

Russos (Ceará) .. $\quad \ldots \quad \ldots$ 144, 159

Saboeiro, Valle do $\quad \ldots \quad$.. $\quad 149$

$\begin{array}{lllll}\text { Sakellarides } & \ldots & \ldots & \ldots & 165\end{array}$

Salgado River .. $\quad$. $\quad \ldots \quad 151$

Salto Grande, Fazenda $\quad$. $\quad 79$

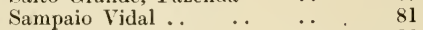

Sant 'Anna do Ipanema .. 123

Santa Catharina .. $13.195,206$

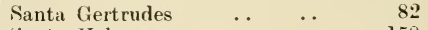

$\begin{array}{llll}\text { Santa Helena } . . & \ldots & \ldots & 158\end{array}$

Santa Luzia (Parahyba) .. $\quad 156$

Santa Luzia (Bahia) .. . . 106. 117

Santa Quitenia (Maranhão) . . 159

$\begin{array}{lllll}\text { Santos } & \ldots & \ldots & \ldots & \ldots 18,71,93\end{array}$

São Antonio $\quad \ldots \quad \ldots \quad \ldots 143,145$

São Bentos River . . . . 15i

$\begin{array}{lllll}\text { São Bras } & \ldots & \ldots & \ldots & 123\end{array}$

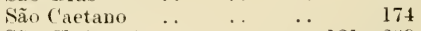

São Christovão .. $\quad \ldots \quad \ldots 121,209$

São Fernando (Rio (irande do Norte) 145

São Francisco River .. 98, 107, 126

São Francisco de Uruburetama 159

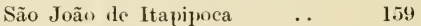

São João dos Patos . . $\quad$. . 159

São Josć, Valle de .. .. 151, 218

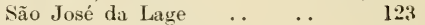

São José do Egvpto . . $\quad \ldots \quad$. 128

São José dos Mattões . $\quad$. . 159

São Luiz (Maranhão) . . . . 159, 200

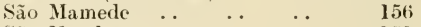

$\begin{array}{lllll}\text { São Nattheus } & \ldots & \ldots & \ldots & 159\end{array}$

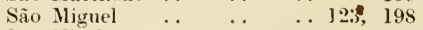

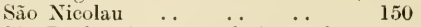

São Paulo: Area, Population and

Railways $\ldots \quad \ldots \quad \ldots 13,19,69$

Coffee . $\quad . . \quad \ldots \quad \ldots, \quad 89$

Cotton Mills. . $\quad \ldots \quad 196,206,208$

Cotton Zones $\quad \ldots \quad \ldots \quad$.. 121

Future Development $\quad \ldots \quad 55$

São Pedro de T'berabinha .. 95

São Pompeu (Ceará) .. $\quad$. $\quad 159$

São Salvador (see "Bahia") ..
São Sebastião

São Vincente Ferrer . . . $\quad 158$

$\begin{array}{llllll}\text { Sapé } & \ldots & \ldots & \ldots & \ldots & 129,175\end{array}$

Saw Gins. $\quad \ldots \quad \ldots \quad 61,109,216$

Schill Bros. of Hanchester .. 109

Schools .

Schüler, H. $\quad$. $\quad \ldots \quad \ldots r, 10$

Scientific Tests of Moeó Cottons $\quad 159$

Sea Island Cotton $\quad . \quad \ldots \quad \ldots \quad 152$ 
PAG F

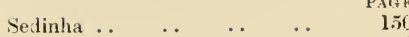

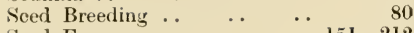

Seed Farms .. ... .. 151, 212

Selection of Plants $\quad \ldots \quad 80,82,140$

Senate .. $\quad \ldots \quad \ldots \quad \ldots \quad \ldots \quad 22$

Sergipe: Area and P'opulation Future

C $\cdots \quad \ldots$ - Cearense necded Geography, Geology

Serrinha .

Sertanejo-arboreo

Sertanejo's Hospitality .

Serra Negra ...

Sertão

Serum-Snake Institute

S'ewing 'Thread, Imports

13,119

56

119

57

$\begin{array}{ll}\ldots 146, & 145 \\ \ldots & 117\end{array}$

. 97

. 140

. $\quad 146$

.. 133, 140

.. 93

. 50

Share System $\ldots 76,80,85,141,146$

Shipping . . . . . $\quad$. $\quad 18$

Shipping Marks of Cotton .. $\quad 169$

$\begin{array}{llll}\text { rick Clubs .. } & \ldots & \ldots & 42\end{array}$

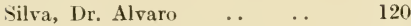

Simonsen, Rolverto Cocrane. 9, 210

Sledge Sorter Tests .. $\quad$.. $\quad 165$

$\begin{array}{lllll}\text { Snake Farm } & \text {. } & \ldots & \ldots & 93\end{array}$

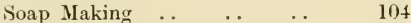

Sobriety .. $\quad \ldots \quad \ldots, \quad \ldots \quad 14$

Sociedade Alg. Nordeste 129, 156, 175, 216

Sociedade Naçional da Agri-

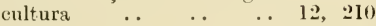

Söhsten \& Co., Julius von 9, 166, 170

Soledade . .. .. .. 157

$\begin{array}{lllll}\text { Sombrio . . } & \ldots & \ldots & \ldots & 154\end{array}$

Siorocaba . $\quad \ldots \quad \ldots \quad \ldots \quad 71,207$

S'ouza (Parahyba) $\quad \ldots \quad$. 157,175

Souza, W. W. Coêlho de $\quad \ldots \quad 9,219$

Spindles in Brazil .. . . 196

Spinning $\quad \ldots \quad \ldots \quad 26,31,67,196$

$\begin{array}{llllll}\text { States } & \ldots & \ldots & \ldots & \ldots & 13,23\end{array}$

Stone Wall Fences .. $\quad . . \quad 150$

Street, Dr. Jorge _. $\quad$.. $\quad 42$

Subsidy to Immigrants _. 15

Sugar $\quad \ldots \quad \ldots 53,104,123,178,181$

Sun-dried Meat . .. .. 184

Sutton, Mark $\ldots \quad$.. $\quad \ldots .99$

Synopsis of Report $\quad \cdots \quad$.. $\quad 210$

Syz, Max. $\quad \ldots \quad \ldots . \quad \ldots \quad 9,211$

Taboleira . $\quad \ldots \quad \ldots \quad$ 148, 151, 155

Tanner, W. Boxwell, Son \& Co. 163

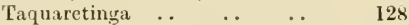

$\begin{array}{llllll}\text { Tarefa } & \ldots & \ldots & \ldots & \ldots & 7\end{array}$

Tatuhy $\ldots \quad \ldots \quad \ldots \quad 76,207,220$

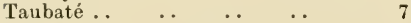

Taxes $\quad \cdots \quad 2_{4}, 39,89,120,125,128$

Temperatures .. $\quad \ldots \quad \ldots . \quad \ldots \quad 17$

$\begin{array}{lllll}\text { Terreiros . } & \ldots & \ldots & \ldots & 93\end{array}$

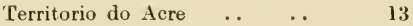

Tests of Mlocó .. $\quad \ldots \quad \ldots .159, \quad$ ] 63

Thanks, Resolution of $12,212,222,224$

Thread Imports . . . . . $\quad 49$

Thread Mill (Pedra) $\quad \ldots \quad \ldots \quad$ 34, 36

$\begin{array}{lllll}\text { Timbaúba } & \ldots & \ldots & \ldots & 128,176\end{array}$

$\begin{array}{llllll}\text { Tobaceo .. } & \ldots & \ldots & \ldots & 104,187\end{array}$

Torrinha-Fazenda $\quad \ldots \quad \ldots, \quad 111$
Trade Unions .. $\quad \ldots \quad \ldots .4 \%$

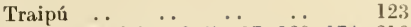

Trajano Medeiros \& Co. 97, 128, 174, 216

Transportation . . . 78, 110, 130

Travel Difficulties .. $\quad \ldots \quad 136$

$\begin{array}{lllll}\text { Treking .. } & \ldots & \ldots & \ldots & 134\end{array}$

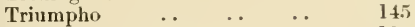

Tucano .. $\quad \ldots \quad \ldots \quad \ldots \quad \ldots \quad 106$

Tury-assú (Maranhão) . $\quad$.. 158

Umary .. $\quad \ldots \quad \ldots \quad \ldots \quad \ldots \quad 15^{\circ}$

União (Ceará) . . $\quad \ldots \quad \ldots \quad \ldots \quad 159$

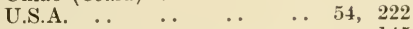

$\begin{array}{lllll}\text { Uruguayana } & \ldots & \ldots & \ldots & 145\end{array}$

Vargem Grandle (Maranhão) . . $\quad 159$

Varieties of Cotton $\quad \ldots \quad 79,83,96,218$

Vasconcellos \& Co., José _. 166, 170

Velha-Fazenda . .. .. 154

Verdão .. 113, 117, 118, I2.2, 124, 125

$129,130,141,143,144,145$ 151, 218 , ete.

Verde (see "Verdão")

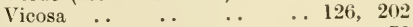

Vidal, Raphael Sampaio . . $\quad 78$

Villa Americana. .. .. 78,81

Villa Nova $\quad . \quad \ldots \quad \ldots \quad \ldots$ 121, 209

$\begin{array}{llllll}\text { Volta } & \ldots & \ldots & \ldots & \ldots & 109\end{array}$

Volta do Espirito Santo .. 153, 165

Volta Grande . . $\quad$.. $\quad \ldots . \quad 109$

Wages: Mill Operatives _. $\quad 32$

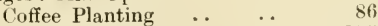

Cotton Picking $\quad \ldots \quad \ldots, 77,155$

Warehouse : Parahyba $\quad . \quad 166$

$\begin{array}{lllll}\text { Sergipe } & \ldots & \ldots & \ldots & 120\end{array}$

Wartegg, E. von Hesse $\quad \ldots \quad 10$

Waste Spinning .. . . 34

Waste in Spinning . . . . 32,37

Water Supply .. $\quad$.. $\quad \ldots .136$

$\begin{array}{lllll}\text { Waterways } & \ldots & \ldots & \ldots & \text { is }\end{array}$

Wax, Carnauba.. .. .. 111, 19:

Wharton, Pedroza \& Co. 157, I66, 171

Weaving .. .. .. 31

"Webber" American [pland . 141

Welfare Work in Cotton Mills.. 42

Wheat .. .. .. .. 188

Wicker-work Wattle Fences .. 133

William Wilson Coêlho de Souza 119

Williams, Palmer \& ('o. .. 170

Wood as Fuel .. $\quad$. $\quad \ldots .39$

Working Week in Cotton Mills 32

Workpeople-Cotton Mills .. $\quad 196$

World's Cotton Position .. 221

World's Shortage of Long Staple

$\begin{array}{lllll}\text { Xarque .. } & \ldots & \ldots & \ldots & \end{array}$

Xique-Xique (or Chique-C'hique) 111

Yarn-Import of Cotton ... 50

Yield $53,55,75,83,88,89,91,109,120$ $124,139,143,150,151,152,154$

Youlten Cotton Opener .. 169

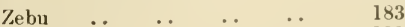

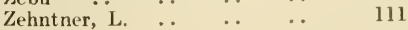



- 



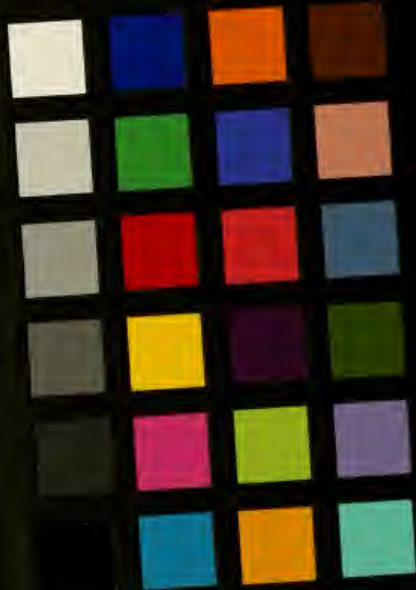